SILAS DIAS DE OLIVEIRA FILHO

\title{
JULGAMENTO FRACIONADO DO MÉRITO E SUAS IMPLICAÇÕES NO SISTEMA RECURSAL
}

Dissertação apresentada ao curso de PósGraduação da Faculdade de Direito da Universidade de São Paulo, área de concentração em Direito Processual, como requisito à obtenção do título de Mestre em Direito.

Orientador: Professor Titular Dr. José Roberto dos Santos Bedaque.

FACULDADE DE DIREITO DA UNIVERSIDADE DE SÃO PAULO

SÃO PAULO 


\section{RESUMO}

O Poder Judiciário brasileiro encontra-se em crise, sendo a excessiva morosidade dos processos seu principal ponto sensível. Diante disso, foram introduzidas alterações normativas destinadas a amenizar o grave cenário existente, como a Emenda Constitucional n. 45/04, que incluiu a razoável duração do processo no rol dos direitos e garantias fundamentais, e a Lei n. 11.232/05, que alterou a estrutura do processo civil de conhecimento e o conceito de sentença.

A indigitada reforma processual implicou rompimento com o princípio da unicidade da sentença, possibilitando o fracionamento do julgamento de mérito, por meio de sentenças parciais.

O presente estudo verificará as possibilidades e os limites de aplicação dessa técnica processual, bem como proporá solução a problemas surgidos no sistema recursal, o qual não foi adaptado à nova realidade processual existente.

A cisão no julgamento do mérito também traz importantes reflexos no momento de formação da coisa julgada material, tema que foi recentemente objeto de análise pelo Superior Tribunal de Justiça. Analisar-se-á o acerto do posicionamento adotado pela jurisprudência, buscando-se alcançar conclusão que tenha o condão de extrair o máximo de efetividade do método estatal de resolução de conflitos.

O tema é intrigante, apresentando diversas possibilidades. Não há dúvidas de que do fracionamento do exame do mérito decorrerão dificuldades e dúvidas, as quais devem ser solvidas pelos operadores do direito, em prol de um processo mais efetivo e capaz de produzir os resultados que dele se esperam. 


\begin{abstract}
The Brazilian Judiciary is in crisis and the excessive length of proceeding isits main sore point. Therefore, legislative amendments were introduced,aiming at alleviating the serious existing scenario, as the Constitutional Amendment 45/04, which included the reasonable duration of the process (speedy trial clause) in the list of fundamental rights and guarantees, and Law 11.232/05, which changed the structure of civil procedure and the concept of sentence.
\end{abstract}

The nominee procedural reform entailed breaking with the principle of unity of the sentence, allowing the fractionation of judgment, through partial sentences.

This study will examine the possibilities and limits of application of this technique, and propose solution to problems arising in the appeal system, which was not adapted to the new reality.

The split in judging the merit also carries important consequences on the formation of res judicata, a topic that has recently been examined by the Superior Tribunal de Justiça. The correctness of the position adopted by the jurisprudence will be analyzed, seeking to reach a conclusion that has the power to extract the maximum effectiveness of the state method of conflict resolution.

The topic is intriguing, presenting several possibilities. There is no doubt that from the partial judgment of merits derives difficulties and doubts, which should be answered by law operators, in favor of a more effective process and capable of producing results that are expected of it. 


\section{SUMÁRIO}

1 Introdução

2 Sentença e julgamento do mérito 12

2.1 Código de Processo Civil de 1973

2.2 Lei 11.232/05 23

3 Julgamento fracionado do mérito 43

$\begin{array}{ll}\text { 3.1 Admissibilidade } & 61\end{array}$

$\begin{array}{lll}3.1 .1 & \text { Princípio da unicidade da sentença } & 64\end{array}$

$\begin{array}{lll}\text { 3.1.2 Princípio da congruência } & 73\end{array}$

3.1.3 Direito constitucional à razoável duração do processo 79

$\begin{array}{ll}3.2 \text { Limites } & 89\end{array}$

3.2.1 Cumulação subjetiva de demandas 97

$\begin{array}{lll}\text { 3.2.2 Cumulação de pedidos } & 100\end{array}$

a) Cumulação simples 102

b) Cumulação sucessiva 103

c) Cumulação eventual 107

d) Pedido alternativo 112

$\begin{array}{ll}\text { 3.2.3 Cumulação de fundamentos } & 114\end{array}$

3.3 Art. 273, $\S 6^{\circ}$ : antecipação de tutela ou julgamento antecipado? 125

3.4 Tratamento da matéria no direito estrangeiro 160

4 Implicações no sistema recursal 167

4.1 Recurso cabível contra a sentença parcial de mérito 167

4.2 Apelação ou agravo de instrumento? 169 
4.3 Óbices procedimentais e possíveis soluções

4.4 Aplicação do princípio da fungibilidade recursal

5 Implicações na formação da coisa julgada material

5.1 Termo inicial do prazo decadencial de ajuizamento da ação rescisória

a) Julgamento de ação rescisória de decisões parciais de mérito proferidas 202 por órgãos jurisdicionais diversos

b) Unicidade da ação e coisa julgada material

c) Desnecessidade de decisão de todas as questões de mérito ou de 208 extinção do processo para formação da coisa julgada material

d) Admissibilidade da formação progressiva da coisa julgada

5.2 Exceção à formação da coisa julgada progressiva

5.3 Incongruências entre coisas julgadas oriundas do mesmo processo

5.4 Execução definitiva da sentença de mérito parcial transitada em julgado 


\section{INTRODUCÃ̃}

O Poder Judiciário brasileiro encontra-se em delicada situação, inapto a atender satisfatoriamente aos anseios da sociedade. É generalizado o sentimento de que o desempenho dos órgãos da Justiça não consegue corresponder às demandas e expectativas sociais, que cada vez mais se ampliam e crescem em complexidade ${ }^{1}$.

Patente a ineficiência no exercício da função jurisdicional, circunstância que relega os consumidores deste serviço público à condição de quase total desamparo e desenganada descrença e a uma postura de acomodação e renúncia consequência já observada pela doutrina processualista há mais de um quarto de século $^{2}$.

Dúvida não há seja a morosidade do processo tida como a grande responsável pela perda de credibilidade do Poder Judiciário junto à população ${ }^{3}$. Expressão disso é a atribuição da qualidade de garantia constitucional à duração razoável do processo (art. $5^{\circ}$, LXXVIII, da Constituição Federal ${ }^{4}$ ), tendo sido várias as reformas processuais visando a alcançá-la.

Não obstante haja múltiplos vetores - institucionais, técnicos, estruturais e culturais - causadores de lentidão e da consequente

\footnotetext{
${ }^{1}$ Cfr. BARBOSA MOREIRA, José Carlos. “Miradas sobre o processo civil contemporâneo”, in Temas de Direito Processual: Sexta Série, Saraiva, São Paulo, 1997, p. 47.

2 Cfr. CALMON DE PASSOS, José Joaquim. "O problema do acesso à justiça no Brasil”, in Revista de Processo, ano X, n. 39, RT, São Paulo, julho-setembro de 1985, p. 87.

${ }^{3}$ Nessa linha, afirma o Min. LUIZ FUX: "aqui e alhures não se calam as vozes contra a morosidade da justiça. $O$ vaticínio tornou-se imediato: 'justiça retardada é justiça denegada' e com esse estigma arrastou-se o Poder Judiciário, conduzindo o seu desprestígio a índices alarmantes de insatisfação aos olhos do povo" (cfr. BRASIL. Senado Federal. "Anteprojeto do novo Código de Processo Civil", disponível em http://www.senado.gov.br/senado/novocpc/pdf/Anteprojeto.pdf, acessado em 16.5.11, p. 7).

${ }^{4}$ Antes mesmo da inclusão do indigitado dispositivo, defendia-se a existência da garantia constitucional a um julgamento em prazo razoável, seja por força do Pacto de São José da Costa Rica, integrante do ordenamento jurídico brasileiro desde 1992, seja por entendê-la inerente ao devido processo legal, constando, ainda que implicitamente, do inciso LIV do art. $5^{\circ}$ da Carta Magna (cfr. DINAMARCO, Cândido Rangel. "Fundamentos do processo civil moderno", v. I, $3^{\text {a }}$ ed., Malheiros, São Paulo, 2000, pp. 894-895).
} 
intempestividade da tutela jurisdicional ${ }^{5}$, o fato é que os fatores ligados à técnica processual sempre foram tidos como os principais responsáveis pelos contornos da quadra vivida, tendo o Poder Público concentrado seus esforços em sucessivas reformas na legislação processual.

Entretanto, é preciso ter em mente que a tão buscada efetividade processual não pode ser resumida a - e nem confundida com - celeridade apenas $^{6}$. Existem outros valores fundamentais ligados à segurança do processo, que não devem ser preteridos sob a escusa de combate à morosidade.

Processo efetivo é aquele capaz de aplicar a regra de direito material, de forma justa e tempestiva, encerrando definitivamente o litígio, sem causar injusto prejuízo a qualquer das partes ${ }^{7}$. Para tanto é necessária uma equação balanceada entre celeridade e segurança, excluída qualquer tentativa de transformar tais valores em fins em si mesmos. Não se deseja apenas uma justiça rápida, mas sim uma justiça melhor ${ }^{8}$.

É necessário, portanto, conferir substancialidade à garantia de acesso aos tribunais ${ }^{9}$ (art. $5^{\circ}, \mathrm{XXXV}$, da Constituição Federal), para que o processo consiga atingir seus escopos $^{10}$ junto aos consumidores da tutela jurisdicional, propiciando uma resposta em tempo razoável, em observância às regras inerentes ao devido processo legal ${ }^{11}$, assegurando, assim, o acesso à ordem jurídica justa ${ }^{12}$.

\footnotetext{
${ }^{5}$ Cfr. CRUZ E TUCCI, José Rogério. “Tempo e processo”, RT, São Paulo, 1997, pp. 100-110.

${ }^{6}$ Cfr. BARBOSA MOREIRA, José Carlos. "O futuro da justiça: alguns mitos”, in Temas de Direito Processual: Oitava Série, São Paulo, Saraiva, 2004, pp. 2-5.

${ }^{7}$ Cfr. CRUZ E TUCCI, José Rogério. "Tempo e processo", RT, São Paulo, 1997, p. 27.

${ }^{8}$ Cfr. BARBOSA MOREIRA, José Carlos. "A efetividade do processo de conhecimento”, in Revista de Processo, n. 74, RT, São Paulo, abril-junho de 1994, p. 128.

${ }^{9} \mathrm{Na}$ lição de CAPPELLETTI E GARTH, "o direito ao acesso efetivo tem sido progressivamente reconhecido como sendo de importância capital entre os novos direitos individuais e sociais, uma vez que a titularidade de direitos é destituída de sentido, na ausência de mecanismos para a sua efetiva reivindicação. $O$ acesso à justiça pode, portanto, ser encarado como o requisito fundamental - o mais básico dos direitos humanos - de um sistema jurídico moderno e igualitário que pretenda garantir, e não apenas proclamar os direitos de todos. $O$ enfoque sobre o acesso - o modo pelo qual os direitos se tornam efetivos - também caracteriza crescentemente o estudo do moderno processo civil. [...] Os juristas precisam, agora, reconhecer que as técnicas processuais servem a funções sociais. [...] $O$ 'acesso' não é apenas um direito social fundamental, crescentemente reconhecido; ele é, também, necessariamente, o ponto central da moderna processualística" (cfr. NORTHFLEET, Ellen Gracie (trad.). "Acesso à justiça”, Fabris, Porto Alegre, 2002, pp. 11-13).

${ }^{10}$ Cfr. CINTRA, Antonio Carlos de Araújo; DINAMARCO, Cândido Rangel; GRINOVER, Ada Pellegrini. "Teoria geral do processo", $20^{a}$ ed., Malheiros Editores, São Paulo, 2004, pp. 24-25.

${ }^{11}$ Cfr. CRUZ E TUCCI, José Rogério. “Tempo e processo”, RT, São Paulo, 1997, pp. 87-88.
} 
Dentre as diversas modificações realizadas visando a alcançar tal objetivo, seja por meio da eliminação de formalismos avoengos e desnecessários, seja através da criação de novas técnicas que consigam atender de modo satisfatório às necessidades sociais em constante mutação ${ }^{13}$, a que implicou maior impacto no sistema processual brasileiro foi a introduzida pela Lei n. 11.232/2005, integrante do "Pacto Republicano" e daquela que ficou conhecida como a terceira fase (ou etapa) da reforma do Código de Processo Civil ${ }^{14}$.

Atribuindo o elevado grau de efetividade presente nas tutelas condenatórias envolvendo obrigação de dar, fazer e não fazer ao fato de que nestes casos se prescinde de processo de execução autônomo para sua efetivação, ventilou-se a transposição deste modelo à embaraçosa e pouco efetiva execução de quantia em dinheiro.

Dessa forma, querendo conferir maior efetividade a esta modalidade de tutela condenatória, o legislador reestruturou o método de trabalho estatal destinado à resolução de $\operatorname{conflitos}^{15}$, criando o denominado "processo sincrético", no qual há a prática, sem solução de continuidade da relação jurídica processual, de diversos atos jurisdicionais que eram realizados em processos diferentes (v.g., cautelar, de execução $)^{16}$.

\footnotetext{
${ }^{12}$ Antonio Carlos de Araújo Cintra, Ada Pellegrini Grinover e CÂndido Rangel Dinamarco lecionam que quatro pontos básicos estão intimamente ligados ao acesso à ordem jurídica justa: a) admissão em juízo; b) devido processo legal; c) justiça das decisões; d) efetividade das decisões (cfr. "Teoria geral do processo", $20^{\mathrm{a}}$ ed., Malheiros Editores, São Paulo, 2004, pp. 33-35).

${ }^{13}$ JosÉ CARLOS BARBOSA MOREIRA aponta três tendências reformadoras presentes no processo civil brasileiro: a) simplificação de procedimentos; b) utilização da técnica do processo coletivo como instrumento de defesa de interesses transindividuais; c) atribuição de maiores poderes ao juiz. Estas medidas teriam como objetivo agilizar a marcha dos processos, descongestionar o Judiciário, facilitar a composição de litígios e, consequentemente, tornar mais efetiva a prestação jurisdicional (cfr. "Os novos rumos do processo civil brasileiro", in Temas de Direito Processual: Sexta Série, Saraiva, São Paulo, 1997, pp. 44-75).

${ }^{14}$ Cfr. JORGE, Flávio Cheim; RODRIGUES, Marcelo Abelha; DIDIER JUNIOR, Fredie. "A terceira etapa da reforma processual civil: comentários às Leis n. 11.187 e 11.232, de 2005; 11.276, 11.277 e 11.280, de 2006", Saraiva,São Paulo, 2006; v. tb. GARCIA, Gustavo Filipe Barbosa. "Terceira fase da reforma do Código de Processo Civil", v. 2, Método, São Paulo, 2006.

${ }^{15}$ Trata-se de definição de processo adotada por JoSÉ RoBERTO DOS SANTOS BEDAQUE (cfr. "Efetividade do processo e técnica processual", Malheiros, São Paulo, 2006, p. 36.).

${ }^{16}$ Cfr. BUENO, Cássio Scarpinella. "A nova etapa da reforma do Código de Processo Civil: comentários sistemáticos às Leis n. 11.187, de 19-10-2005, e 11.232, de 22-12-2005”, v. 1, Saraiva, São Paulo, 2006, p. 12.
} 
Buscou-se, pela nova técnica, extirpar do direito brasileiro a tutela condenatória tradicional, efetivada mediante dois processos diferentes, um de cognição e outro de execução. Assim, a eliminação da crise de adimplemento de obrigações deverá ocorrer, de forma uniformizada, em processo único, que se divide em uma etapa cognitiva seguida de uma fase executiva, separadas por uma sentença denominada de executiva lato $\operatorname{sen} \mathrm{su}^{17}$.

Nessa linha, a reforma eliminou, como regra, o processo de execução autônomo ${ }^{18}$, de modo a propiciar a efetivação da tutela condenatória mediante a prática, no mesmo processo, de todos os atos executivos necessários, evitando-se, assim, o ajuizamento de nova ação, bem como das implicações daí decorrentes (v.g., nova citação do devedor) ${ }^{19}$.

Embora louvável o intuito do legislador, a medida adotada

não é imune a críticas.

Em primeiro lugar é necessário considerar que o processo judicial é um procedimento realizado em contraditório, cujas variações internas devem ser abonadas tão-somente pela necessidade de adequar a técnica processual aos objetivos almejados ${ }^{20}$.

Destarte, este novo fenômeno criado pela Lei n. 11.232/05, no qual são praticados, aproveitando-se a mesma relação jurídica processual, atos cognitivos, antecipatórios, acautelatórios e executivos, não representa mais do que mera alteração procedimental, que deve buscar sua justificação na aptidão de obter o

\footnotetext{
${ }^{17}$ Cfr. BEDAQUE, José Roberto dos Santos. "Algumas considerações sobre o cumprimento da sentença condenatória", in Revista do Advogado, n. 85, AASP, São Paulo, maio de 2006, p. 72.

${ }^{18}$ Em tempo: por óbvio o processo de execução autônomo não foi extirpado por completo do ordenamento jurídico brasileiro, sendo ainda preservado para a execução de títulos executivos extrajudiciais e os judiciais formados sem que haja prévia fase judicial cognitiva. Trata-se, no segundo caso, de algumas das hipóteses previstas no art. 475-N, do Código de Processo Civil, tais como a sentença penal condenatória, a sentença arbitral e a sentença estrangeira. Feito o necessário contraponto, retorna-se à análise da inovação trazida pela Lei n. 11.232/05.

${ }^{19}$ Cfr. VAREJÃO, José Ricardo do Nascimento. "As classificações, a lei 11.232/2005 e o 'novo' conceito de sentença", in WAMBIER, Teresa Arruda Alvim (coord.). Aspectos Polêmicos da Nova Execução, 3 : de títulos judiciais, Lei 11.232/2005, RT, São Paulo, 2006, pp. 370-371.

${ }^{20}$ Cfr. BEDAQUE, José Roberto dos Santos. "Efetividade do processo e técnica processual", Malheiros, São Paulo, 2006, p. 56.
} 
fim a que se propõe: propiciar maior efetividade à tutela condenatória de pagamento em dinheiro.

Todavia, o legislador partiu de premissa falsa na formulação da alteração em tela, pois a desnecessidade de se efetivar as tutelas condenatórias de obrigação de dar, fazer ou não fazer em processo autônomo não é causa de sua maior capacidade satisfativa. Não. Muito pelo contrário, o que se verifica é que a desnecessidade de processo de execução autônomo em hipóteses tais é consequência da natural maior efetividade que é inerente a estas modalidades de tutela condenatória.

De fato, há tutelas jurisdicionais que propiciam a plena satisfação do direito trazido a juízo com a simples prolação da decisão pelo magistrado. São aquelas destinadas a solucionar crises de direito material envolvendo a certeza quanto a determinada relação jurídica ou a necessidade de modificação de situação jurídica. Nestas duas hipóteses (tutelas declaratória e constitutiva), o próprio ato decisório do magistrado é suficiente para concretizar o direito postulado, não sendo necessária a prática de qualquer medida posterior. Trata-se de tutelas plenamente satisfativas $^{21}$.

Diferente é a situação em relação à tutela condenatória, já que a crise de direito material decorrente do inadimplemento de uma obrigação não é eliminada com a simples prolação da decisão judicial. A integral satisfação da pretensão somente ocorre mediante a prática de atos materiais aptos a alcançar tal mister ${ }^{22}$, salvo se houver colaboração espontânea do devedor.

Dessa forma, inexistindo adimplemento espontâneo, o credor deverá requerer o cumprimento da obrigação que, a depender da espécie, poderá ser realizado por meio de métodos coercitivos (no caso de obrigações de fazer, não fazer e entregar coisa - v.g., astreintes, ordem, etc.) ou sub-rogativos (na hipótese de

\footnotetext{
${ }^{21}$ Cfr. BEDAQUE, José Roberto dos Santos. "Algumas considerações sobre o cumprimento da sentença condenatória", in Revista do Advogado, n. 85, AASP, São Paulo, maio de 2006, p. 65.

${ }^{22}$ Cfr. BEDAQUE, José Roberto dos Santos. "Algumas considerações sobre o cumprimento da sentença condenatória", in Revista do Advogado, n. 85, AASP, São Paulo, maio de 2006, p. 65.
} 
obrigação de pagar quantia - v.g., penhora, alienação do bem, realização de ativo e pagamento $)^{23}$.

A efetividade da tutela condenatória depende da prática destes atos materiais de execução, pouco importando se se realizam em processo novo ou no mesmo processo.

É certo, porém, não haver dúvida de que a simplificação procedimental tem o condão de conferir celeridade e efetividade, sendo válida, portanto, a opção por método tido pelo legislador como mais eficaz e apto a alcançar o escopo da jurisdição, tal qual a técnica de passagem da cognição à execução sem solução de continuidade da relação jurídica processual.

Contudo, não é a mera eliminação da necessidade de instauração de novo processo autônomo para a satisfação do direito judicialmente reconhecido que irá conferir à tutela condenatória a capacidade de por si só dar cabo do integral cumprimento do comando contido na sentença ${ }^{24}$.

Desse modo, não se pode olvidar que para o credor receber a quantia que lhe é de direito, necessário possua o devedor bens suficientes a tanto; para que o requerente obtenha o quadro a que famoso artista se obrigou a pintar, é preciso que o requerido voluntariamente - ainda que não de forma espontânea - o faça.

Se inexistir patrimônio apto a adimplir a obrigação pecuniária ou se o réu se recusar a realizar obrigação de fazer personalíssima, arcando por sua conta e risco com todas as consequências do descumprimento da decisão judicial, estará configurada situação de não efetividade da tutela condenatória para a qual inexiste alteração legislativa apta a trazer solução ${ }^{25}$.

\footnotetext{
${ }^{23}$ Cfr. BEDAQUE, José Roberto dos Santos. "Algumas considerações sobre o cumprimento da sentença condenatória", in Revista do Advogado, n. 85, AASP, São Paulo, maio de 2006, p. 69.

${ }^{24}$ Cfr. BEDAQUE, José Roberto dos Santos. "Algumas considerações sobre o cumprimento da sentença condenatória", in Revista do Advogado, n. 85, AASP, São Paulo, maio de 2006, pp. 68-69.

${ }^{25}$ Diante de tal situação material geradora de falta de efetividade, afirma-se que "nada mais igual do que a execução antes e depois da reforma promovida pela Lei n. 11.232/2005" (cfr. ASSIS, Araken de. "Manual da execução civil", $10^{\mathrm{a}}$ ed., RT, São Paulo, 2006, p. 7).
} 
Não obstante isso, legemhabemus, tendo sido conferida estrutura inédita ao processo civil brasileiro, a qual demandou alterações na legislação processual aptas a comportá-la. Modificações estas que não se limitaram às técnicas predominantemente realizadas na - agora - fase de execução, visto que, para adaptar o procedimento ao novel "sincretismo processual", incursões legislativas foram necessárias também na fase cognitiva ${ }^{26}$.

Como não há mais solução de continuidade entre cognição e execução, passou a ser flagrantemente inapropriado conceituar sentença como o ato do juiz que extingue o processo, com ou sem análise de mérito ${ }^{27}$.

Abandonou-se o critério topológico vigente na redação original do art. 162, § $1^{\circ}$, do Código de Processo Civil, valendo-se o legislador de definição com base no conteúdo do ato jurisdicional, visto que este não mais possui o condão de necessariamente extinguir o processo ${ }^{28}$. Assim, a sentença tornou-se o ato do juiz que implica alguma das hipóteses contidas nos artigos 267 e 269, do Código ${ }^{29}$.

Nessa mesma toada, foi modificado o art. 463, do Código de Processo Civil, visto ser incompatível com o modelo adotado a ideia de que o juiz, ao prolatar a sentença, cumpre e encerra seu dever jurisdicional. De acordo com a atual sistemática, este ofício pode se estender para além da fase cognitiva, vindo a se encerrar somente ao término da fase de cumprimento de sentença ${ }^{30}$.

\footnotetext{
${ }^{26}$ Cfr. SICA, Heitor Vitor Mendonça. “Algumas implicações do novo conceito de sentença, de acordo com a Lei n. 11.232/2005", in CARMONA, Carlos Alberto (coord.). Reflexões sobre a reforma do Código de Processo Civil, Atlas, São Paulo, 2007, p. 186.

${ }^{27}$ Cfr. CARNEIRO, Athos Gusmão. "Do 'cumprimento da sentença', conforme a Lei n. 11.232/2005. Parcial retorno ao medievalismo? Por que não?”, in Revista do Advogado, n. 85, AASP, São Paulo, maio de 2006, p. 32.

${ }^{28}$ Como é sabido, apesar da literalidade da lei, a sentença, ainda em seu conceito anterior à reforma, raramente de fato encerrava o processo: “Diga-se, aliás, que a sentença só punha 'termo ao processo' se dela não fosse interposto recurso nenhum, e se dela não coubesse a execução imediata prevista em procedimentos especiais... (mesmo assim, remanescia a questão das condenações sucumbenciais)" (cfr. CARNEIRO, Athos Gusmão. "Do 'cumprimento da sentença', conforme a Lei n. 11.232/2005. Parcial retorno ao medievalismo? Por que não?", in Revista do Advogado, n. 85, AASP, São Paulo, maio de 2006, p. 33).

${ }^{29}$ Cfr. OLIANI, José Alexandre Manzano. "Cumprimento da sentença interlocutória que condena ao pagamento de soma, de acordo com a Lei 11.232/05", in SANTOS, Ernane Fidélis (coord.); WAMBIER, Luiz Rodrigues (coord.); NERY JR., Nelson (coord.); WAMBIER, Teresa Arruda Alvim (coord.). Execução civil: estudos em homenagem ao professor Humberto Theodoro Júnior, RT, São Paulo, 2007, pp. 173-174.

30 Além disso, Athos GuSMÃo CARNEIRo observa que desde sempre o juiz praticava seu ofício jurisdicional não somente ao prolatar a sentença, fazendo-o ao longo de todo o processo, "desde que
} 
Ocorre que tais alterações tiveram implicações não previstas pelo legislador, tendo em vista que sua vontade de forma alguma se confunde com a da lei ${ }^{31}$.

O novo conceito de sentença, o qual deixou de contemplar expressamente a extinção do processo como característica definidora, aliado à constatação de que com sua prolação o juiz não mais encerra seu ofício jurisdicional, fez com que parcela da doutrina passasse a admitir ter a Lei n. 11.232/2005 permitido ao juiz fracionar o julgamento do mérito no curso do processo, proferindo tantas sentenças parciais quantas sejam necessárias ao esgotamento da apreciação da integralidade da(s) demanda(s) trazida(s) a juízo ${ }^{32}$.

Ou seja, independentemente de ter o legislador objetivado tão-somente adaptar a etapa cognitiva ao novo modelo de método de trabalho instituído, o fato é que as alterações geraram consequências não esperadas que devem ser enfrentadas pelos operadores do direito.

A realidade desenhada é cristalina: a sentença passou a ser conceituada pelo conteúdo, não sendo mais imprescindível para sua qualificação o efeito de encerrar o processo - ou eventual fase cognitiva ${ }^{33}$. E não há outra opção ao processualista a não ser se debruçar sobre o fenômeno e dele extrair interpretação que

admite a petição inicial, e não apenas ao proferir a sentença; além disso, com a prolação da sentença embora ato culminante do processo, o juiz não acaba o ofício jurisdicional, que prosseguirá com as atividades processuais decorrentes da interposição de recurso e do cumprimento da própria sentença ou do acórdão que eventualmente venha a substituí-la" (cfr. "Do 'cumprimento da sentença', conforme a Lei n. 11.232/2005. Parcial retorno ao medievalismo? Por que não?", in Revista do Advogado, n. 85, AASP, São Paulo, maio de 2006, pp. 33-34).

${ }^{31}$ CARLOS AlBerto CARMONA afirma que durante as reuniões realizadas em Brasília quando da discussão da reforma, em nenhum momento foi abordada a possibilidade do "fatiamento" do julgamento da lide, cabendo ao Superior Tribunal de Justiça decidir acerca da questão à luz de eventuais incompatibilidades do julgamento antecipado parcial com o sistema recursal - ponto que representa um dos objetos de análise do presente trabalho (cfr. "Ensaio sobre a sentença arbitral parcial", in Revista de Processo, n. 165, RT, São Paulo, nov. 2008, p. 14).

${ }^{32}$ Cfr. SICA, Heitor Vitor Mendonça. "Algumas implicações do novo conceito de sentença, de acordo com a Lei n. 11.232/2005", in CARMONA, Carlos Alberto (coord.). Reflexões sobre a reforma do Código de Processo Civil, Atlas, São Paulo, 2007,p. 187.

${ }^{33}$ Cr. NEVES, Daniel Amorim Assumpção. "O novo conceito de sentença de mérito e os problemas recursais", in BRUSCHI, Gilberto Gomes (coord.); SHIMURA, Sérgio (coord.). Execução civil e cumprimento de sentença, v. 2, Método, São Paulo, 2007, p. 77. 
confira ao processo a máxima capacidade de produção de resultados, à luz do devido processo legal.

Dessa forma, a fim de possibilitar a utilização da técnica da desacumulação de demandas - ou melhor, da técnica de decomponibilidade do objeto processual litigioso - por meio da prolação de sentenças parciais ao longo do processo sincrético, defende-se ter sido afastado do ordenamento jurídico brasileiro o princípio da unicidade do julgamento de mérito, sendo possível ao juiz, em homenagem à celeridade e à efetividade processuais, julgar de forma fatiada o objeto litigioso, tão logo haja demandas maduras e prontas a tanto, prosseguindo-se o processo somente em relação àquelas que ensejassem maior dilação probatória.

Trata-se, em parte, de renovação da discussão travada quando da inclusão do $\S 6^{\circ}$ no art. 273 do Código de Processo Civil (antecipação de tutela de parcela incontroversa do pedido), ocasião em que parte da doutrina identificou tal hipótese como decisão calcada em cognição exauriente, representando verdadeiro fracionamento do julgamento do mérito ${ }^{34}$.

Além disso, a possibilidade de prolação de mais de uma sentença ao longo do processo trouxe repercussões significativas na seara recursal, visto que esta não foi contemplada pela reforma, deixando de receber as adaptações necessárias decorrentes da modificação do conceito de sentença.

Diante da impossibilidade de remessa dos autos à instância superior, muito discute a doutrina acerca do recurso cabível contra a sentença parcial. Fala-se em utilização do agravo de instrumento, chegando-se até mesmo à inovação de se propor o emprego de "apelação por instrumento" 35.

\footnotetext{
${ }^{34}$ Cfr. MARINONI, Luiz Guilherme. "Tutela antecipatória e julgamento antecipado. Parte incontroversa da demanda", RT, $5^{\text {a }}$ ed., São Paulo, 2002; DIDIER JUNIOR, Fredie. "Inovações na antecipação dos efeitos da tutela e a resolução parcial do mérito", in Revista de Processo, n. 110, RT, São Paulo, abriljunho de 2003, pp. 225-249.

${ }^{35}$ Cfr. MARTINS, Renato Castro Teixeira. "Apelação por instrumento", in MEDINA, José Miguel Garcia (coord.); CRUZ, Luana Pedrosa de Figueiredo (coord.); CERQUEIRA, Luiz Otávio Siqueira de (coord.); GOMES JR., Luis Manoel (coord.). Os poderes do juiz e o controle das decisões judiciais: estudos em homenagem à professora Teresa Arruda Alvim Wambier, RT, São Paulo, 2008, pp. 836-845.
} 
Destarte, enquanto não são fixadas pela jurisprudência as balizas a serem seguidas, volta a assumir papel de central relevo no sistema o princípio da fungibilidade, que, diante da situação de insegurança criada, encontra atualmente fértil campo de incidência ${ }^{36}$.

Ademais, devem ser analisados, ainda, os reflexos do julgamento fracionado do mérito na formação da coisa julgada material e no manejo de eventual ação rescisória, sendo imprescindível considerar o teor da Súmula n. 401, do Superior Tribunal de Justiça, a qual, ao adotar criticado entendimento, prescreve que " $o$ prazo decadencial da ação rescisória só se inicia quando não for cabível qualquer recurso do último pronunciamento judicial".

Nesse contexto, verifica-se que, além de uma nova proposta de método estatal de solução de conflitos, a Lei n. 11.232/2005 trouxe consigo relevantes incertezas. Há intensa discussão doutrinária quanto (i) ao conceito de sentença; (ii) à possibilidade de julgamento fracionado do mérito; (iii) ao recurso cabível contra a decisão que analisa parcela do mérito; (iv) à formação da coisa julgada material e o início do prazo para ajuizamento de ação rescisória em tais situações.

O objetivo do presente trabalho é examinar o fenômeno do julgamento fracionado do mérito à luz do atual conceito de sentença e suas implicações, a fim de se buscar soluções aptas a extrair o máximo de resultado do processo ${ }^{37}$.

Mister, portanto, enfrentar o tema proposto, tendo em mente o perene conflito de valores existente no âmbito do direito processual civil (segurança $\mathrm{x}$ celeridade ${ }^{38}$ ), o qual deve ser equacionado ${ }^{39}$ pelos aplicadores do direito de

\footnotetext{
${ }^{36}$ Cfr. NEVES. Daniel Assumpção Amorim. "O novo conceito de sentença de mérito e os problemas recursais", in BRUSCHI, Gilberto Gomes (coord.); SHIMURA, Sérgio (coord.). Execução civil e cumprimento de sentença, v. 2, Método, São Paulo, 2007, p. 84.

${ }^{37}$ Cfr. SICA, Heitor Vitor Mendonça. "Algumas implicações do novo conceito de sentença, de acordo com a Lei n. 11.232/2005", in CARMONA, Carlos Alberto (coord.). Reflexões sobre a reforma do Código de Processo Civil, Atlas, São Paulo, 2007, p. 190.

${ }^{38}$ Cfr. BEDAQUE. José Roberto dos Santos. "Efetividade do processo e técnica processual", Malheiros, São Paulo, 2006, p. 49.

${ }^{39}$ José CARLOS BARBOSA MoReira ensina que "no direito, como na vida, a suma sabedoria consiste em conciliar, tanto quanto possível, solicitações contraditórias, inspiradas em interesses opostos e igualmente valiosos, de forma que a satisfação de um deles não implique o sacrifício total de outro"
} 
acordo com as disposições constitucionais aplicáveis, sempre em busca da tão almejada efetividade processual.

(cfr. "Efetividade do processo e técnica processual", in Temas de Direito Processual: Sexta Série, Saraiva, São Paulo, 1997, p. 21). 


\section{SENTENCA E JULGAMENTO DO MÉRITO}

De rigor tecer alguns apontamentos iniciais acerca do conceito de sentença, bem como do corte metodológico imprescindível ao presente estudo, fixando uma primeira e importante premissa.

A definição do provimento judicial em tela consiste em atividade das mais ásperas em sede doutrinária, não havendo formulação unívoca ${ }^{40}$. Diante disso, não se procurará definir sentença em abstrato $^{41}$ - se é que tal empreitada é passível de ser levada a bom termo -, passando-se pela evolução do instituto ao longo das eras, tema deveras complexo ${ }^{42}$.

Buscar-se-á, por sua vez, chegar a um significado para o ato à luz do ordenamento jurídico brasileiro em vigor ${ }^{43}$, de modo que, para os fins ora propostos, é suficiente o cotejo analítico entre as classificações legais de 1973 e 2005.

Apesar da deficiência inerente às definições jurídicas positivadas, visto não possuírem a aptidão de acompanhar de forma satisfatória a

\footnotetext{
${ }^{40}$ Ora, "conceituar sentença é tarefa inglória. Diversos doutrinadores de peso, nacionais e estrangeiros, ao longo de seguidas gerações se debruçaram sobre o assunto, mas mesmo assim ainda não se alcançou uma definição isenta de críticas consideráveis" (cfr. FICHTNER, José Antonio; MONTEIRO, André Luís. "Sentença parcial de mérito na arbitragem", in Temas de arbitragem: primeira série, Renovar, São Paulo, 2010, p. 153).

${ }^{41}$ De acordo com GIUSEPPE CHIOVENDA, sentença "é a provisão do juiz que, recebendo ou rejeitando a demanda do autor, afirma a existência ou ainexistência de uma vontade concreta de lei que lhe garanta um bem ou respectivamente a inexistência ou existência de uma vontade de lei que garanta um bem ao réu. Receber a demanda do autor significa atuar a lei a seu favor, segundo os casos, de modo positivo ou negativo, isto é, afirmando a existência de uma vontade de lei que garanta um bem ao autor ou negando a existência de uma vontade de lei que garanta um bem ao réu. Semelhantemente, rejeitar a demanda significa atuar a lei a favor do réu, segundo os casos, de modo positivo ou negativo, ou negando a existência de uma vontade de lei que garanta um bem ao autor ou afirmando a existência de uma vontade de lei que garanta um bem ao réu" (cfr. "Instituições de direito processual civill", Bookseller, Campinas, 2009, pp. 212-213).

${ }^{42}$ cfr. CRUZ E TUCCI, José Rogério; AZEVEDO, Luis Carlos de. "Lições de história do processo civil romano",1a ed., RT, São Paulo, 2001; v. tb. NORONHA, Carlos Silveira. "Sentença civil - perfil histórico e dogmático", RT, São Paulo, 1995.

${ }^{43}$ Nesse ponto, cabe invocar a lição de BARBOSA MOREIRA inserta em sua clássica obra sobre o juízo de admissibilidade dos recursos cíveis. O mestre carioca afirma a necessidade de se ater "precipuamente aos dados do direito positivo", visto que "não há nenhum céu de puras essências, onde se logre descobrir um conceito de recurso anterior a que revela o sistema da lei". Tal ensinamento aplica-se com idêntica validade se transportado à categoria processual da sentença (cfr. "Juízo de admissibilidade no sistema dos recursos civis", Borsói, Rio de Janeiro, 1968, p. 10).
} 
mutabilidade das relações sociais ${ }^{44}$, o Legislativo pátrio optou por trazer expressamente no bojo da Lei n. 5.869/1973 a categorização dos atos do juiz (art. 162), estabelecendo o que esperava fosse identificado como sentença (art. 162, § $1^{\circ}$ ).

Ora, é sabido que as classificações não são verdadeiras ou falsas, mas sim úteis ou inúteis ${ }^{45}$. Mister, portanto, examinar qual utilidade o legislador vislumbrou existir na classificação proposta, voltando os olhos, ainda que rapidamente, para a ordem jurídica processual que lhe antecedeu.

No Código de Processo Civil de 1939, eram previstos dois tipos de sentenças, contra as quais eram cabíveis recursos também diversos: se a decisão houvesse analisado o mérito da demanda (sentença definitiva), interpunha-se recurso de apelação (artigos 280 a 290); se proferida decisão terminativa, cabia agravo de petição (art. 846). Nessa linha, por tal sistema, o conteúdo do ato determinava o recurso a ser utilizado $^{46}$, gerando situações de incerteza ${ }^{47}$, diante da dificuldade de se definir o próprio conceito de mérito ${ }^{48}$.

Diante desta situação, entendeu-se ser necessária mudança apta a conferir maior utilidade e eficiência ao instrumento estatal de composição de

\footnotetext{
${ }^{44}$ Conforme afirma PEDRO BATISTA MARTINS, "a eficácia normativa se perpetua no tempo quanto mais aberto for o seu conteúdo. Os conceitos, quando positivados, tendem a se distorcer com o tempo, por força da dinâmica das relações jurídicas e do inescapável confronto com o caso concreto, o que expõe, realisticamente, as suas inconsistências e imperfeições" (cfr. "A arbitragem e o mito da sentença parcial”, in CARMONA, Carlos Alberto (coord.); LEMES, Selma Ferreira (coord.); MARTINS, Pedro Batista (coord.). Arbitragem: Estudos em Homenagem ao Prof. Guido Fernando da Silva Soares in memoriam, Atlas, São Paulo, 2007, p. 279).

45 Segundo GENARO CARRIÓ, "las clasificaciones no son ni verdaderas ni falsas, son serviciales o inútiles; sus ventajas o desventajas están supeditadas al interés que guía a quien las formula, y a su fecundidad para presentar un campo de conocimiento de una manera más fácilmente comprensible o más rica en consecuencias prácticas deseables" (cfr. "Notas sobre derecho y lenguaje". 4" edição, AbeledoPerrot, Buenos Aires, 1990, p. 99).

46 Cfr. LUCON, Paulo Henrique dos Santos. "Sentença e liquidação no CPC (Lei $\quad$ n. 11.232/2005)", $\quad$ disponível em http://novo.direitoprocessual.org.br/fileManager/Paulo_Lucon__Sentena_e_liquidao_no_CPC.doc, acessado em 6.6.11, p. 2.

${ }^{47}$ Antevendo eventuais dificuldades práticas, o próprio CPC de 1939 previa expressamente a aplicação da fungibilidade recursal: "Art. 810. Salvo a hipótese de má-fé ou erro grosseiro, a parte não será prejudicada pela interposição de um recurso por outro, devendo os autos ser enviados à Câmara, ou turma, a que competir o julgamento".

${ }^{48}$ Havia divergência acerca da natureza de determinadas decisões judiciais, que "segundo a doutrina eram terminativas, mas os tribunais entendiam que fossem de mérito (falta de legitimidade ad causam)" (cfr. DINAMARCO, Cândido Rangel. "Instituições de direito processual civill", v. III, 5a ed., Malheiros Editores, São Paulo, 2005, p. 653).
} 
litígios, sendo adotado em 1973 critério topológico ${ }^{49}$ para a classificação dos pronunciamentos judiciais, tido como capaz de eliminar esta grande celeuma existente na ordem jurídica processual pretérita: a complexidade e a inexatidão do sistema recursal $^{50}$. Para tanto, empregou-se definição fundada nos efeitos que o ato produziria (“ato pelo qual o juiz põe termo ao processo"), em detrimento de seu conteúdo (“decidindo ou não o mérito da causa").

Objetivou o legislador, destarte, construir conceito de sentença com base em critério tido como coerente, o qual permitia identificar com maior exatidão o recurso adequado a sua impugnação, bem como compatível com a estrutura lógica do método então vigente, no qual havia rígida divisão das etapas cognitiva e executiva em processos autônomos.

A concepção positivada, apesar de cumprir com razoável dose de eficiência o fim a que foi desenhada ${ }^{51}$ - tendo sido elucidadas, ao longo das três décadas em que vigeu, boa parte das dúvidas que ainda eram suscitadas acerca da recorribilidade das decisões ${ }^{52}$-, perdeu a capacidade de atender aos anseios da população.

Em determinado momento histórico, percebeu-se que a simplificação recursal não foi suficiente para atingir a almejada efetividade processual, tendo a comunidade científica e, posteriormente, o legislador considerado como

\footnotetext{
${ }^{49}$ Cfr. BARBOSA MOREIRA, José Carlos. "Comentários ao Código de Processo Civil", v. V, $10^{\mathrm{a}}$ ed., Forense, Rio de Janeiro, 2002, p. 241.

50 Após fazer um panorama das principais deficiências existentes no Código de Processo Civil de 1939, no tocante ao tratamento das questões recursais, as quais, em razão da falta de precisão terminológica e incoerência, causavam sérios transtornos na identificação da natureza da decisão e, consequentemente, do meio de impugnação cabível, ALFREDo BUZAID afirma que um dos objetivos do Código de 1973 foi simplificar o sistema de recursos, definindo sentença e decisão interlocutória por meio de critério coerente e estabelecendo de forma clara o recurso cabível cada uma delas (cfr. BRASIL. Congresso Nacional. “Exposição de motivos do Código de Processo Civil, Lei n. 5.869, de 11 de janeiro de 1973”, disponível em http://www.ombadvocacia.com.br/acervo/CODIGOS/CODIGOPROCESSOCIVIL.PDF, acessado em 6.7.11, pp. 9-11).

${ }^{51}$ Cfr. VAREJÃO, José Ricardo do Nascimento. “As classificações, a lei 11.232/2005 e o 'novo' conceito de sentença", in WAMBIER, Teresa Arruda Alvim (coord.). Aspectos Polêmicos da Nova Execução, 3: de títulos judiciais, Lei 11.232/2005, RT, São Paulo, 2006, p. 373.

52 Cfr. LUCON, Paulo Henrique dos Santos. "Sentença e liquidação no CPC (Lei $\quad n$. 11.232/2005)", $\quad$ disponível em
} http://novo.direitoprocessual.org.br/fileManager/Paulo_Lucon__Sentena_e_liquidao_no_CPC.doc, acessado em 6.6.11, pp. 1-2. 
imperiosa a adoção de novo modelo estatal de solução de conflitos, capaz de superar a dicotomia existente entre cognição e execução - o denominado "processo sincrético" 53.

Adveio, então, a Lei n. 11.232/2005 que alterou a redação do artigo 162, § $1^{\circ}$, do Código de Processo Civil, modificando o critério utilizado na classificação dos atos judiciais. Desta vez entendeu-se ser de utilidade maior ao sistema ter por norte a viabilização do novo modelo de processo, já que a definição anterior obstaria a pretendida eliminação da solução de continuidade entre as etapas cognitiva e executiva da efetivação da tutela condenatória. Assim, a sentença deixou de ser o ato que põe fim ao processo (abandono do critério topológico) para tornar-se o ato do juiz que tem determinado conteúdo previsto em lei ${ }^{54}$ ("implica algumas das situações previstas nos arts. 267 e 269 desta Lei”).

Ora, da singela análise feita verifica-se que houve mudança no conceito positivado de sentença, trocando-se os critérios de classificação do ato com o objetivo de adaptá-lo aos fins buscados pelo legislador. Em um primeiro momento, buscou-se a efetividade do processo por meio da simplificação do sistema recursal, adotando-se critério apto a satisfazer tal necessidade. Posteriormente, visualizou-se que a arquitetura processual existente não mais era suficiente a alcançar o objetivo cobiçado (processo efetivo), tendo sido imprescindível modificar a classificação de sentença até então em vigor, a fim de adaptá-la ao novo modelo sincrético introduzido.

Sendo assim, conclui-se que, para atender aos objetivos decorrentes da política processual adotada em determinada época, é dado ao legislador trabalhar o conceito de sentença, dando-lhe o significado que se mostrar mais compatível aos fins visados ${ }^{55}$, não havendo grande utilidade prática em considerar a

\footnotetext{
${ }^{53}$ Cfr. BUENO, Cássio Scarpinella. "A nova etapa da reforma do Código de Processo Civil: comentários sistemáticos às Leis n. 11.187, de 19-10-2005, e 11.232, de 22-12-2005”, v. 1, Saraiva, São Paulo, 2006, p. 12.

${ }^{54}$ Maiores considerações acerca deste ponto serão realizadas no item 2.2. De todo modo, adianta-se que não foi abandonado integralmente o critério topológico, o qual ainda é empregado na definição das sentenças terminativas.

${ }^{55}$ CÂNDIDO RANGEL DinAmARCOafirma que o legislador de 1973 rompeu "com a tradicional caracterização da sentença segundo o seu conteúdo substancial, consistente em considerar como tal a decisão de mérito" (cfr. "Instituições de direito processual civil", v. III, $5^{\mathrm{a}}$ ed., Malheiros Editores, São Paulo, 2005, p. 653).
} 
sentença unicamente como categoria abstrata, aferível a priori, independentemente do contexto normativo em que está inserido ${ }^{56}$.

Do exposto, é possível fixar uma primeira premissa: o conteúdo e o significado do conceito de sentença é definido pelo legislador ${ }^{57}$, conforme os escopos visados, os quais decorrem da política processual adotada em determinado momento histórico, devendo, portanto, ser analisado à luz da ordem jurídica vigente ${ }^{58}$.

Passa-se, então, à análise mais aprofundada da transição havida entre os modelos de 1973 e 2005.

\subsection{CÓDIGO DE PROCESSO CIVIL DE 1973}

Conforme visto acima, o Código de Processo Civil de 1973 adotou classificação dos atos judiciais com base no maior grau de utilidade por ela proporcionado em comparação com a ordem processual anterior. A vantagem foi identificada na simplificação do sistema recursal. Buscou-se facilitá-lo por meio da adoção de critério eminentemente prático na definição dos atos judiciais recorríveis, circunstância que propiciou uma identificação mais precisa do meio adequado à sua impugnação ${ }^{59}$.

\footnotetext{
${ }^{56}$ Construindo raciocínio semelhante ao exposto, NELSON NERY JR. e RoSA MARIa DE ANDRADE NERY aduzem que "nenhum outro parâmetro anterior ao da lei, por mais importante e científico que seja, poderia ser utilizado para estabelecer a natureza e a espécie do pronunciamento judicial. O critério, fixado ex lege, tinha apenas a finalidade como parâmetro classificatório. Toda e qualquer outra tentativa de classificação do pronunciamento do juiz que não se utilizasse do elemento teleológico deveria ser interpretada como sendo de lege ferenda" (cfr. "Comentários ao Código de Processo Civil e legislação extravagante”, 9ª ed., RT, São Paulo, 2006, p. 372).

${ }^{57}$ Nessa linha, "sentença é o que o legislador diz ser sentença" (cfr. BONDIOLI, Luis Guilherme Aidar. "O novo CPC: a terceira etapa da reforma", Saraiva, São Paulo, 2006, p. 43).

${ }^{58}$ Nesse sentido, "o conceito de sentença é jurídico-positivo, definido pelo legislador de acordo com os objetivos a serem perseguidos. Varia, portanto, de ordenamento para ordenamento" (cfr. LUCCA, Rodrigo Ramina de. "Antecipação de tutela da parcela incontroversa do mérito e o conceito de sentença", disponível

em http://www.abdpc.org.br/abdpc/artigos/Rodrigo\%20Ramina\%20de\%20Lucca.pdf, acessado em 28.6.11., p. 9).

${ }_{59}$ Indo ao encontro do afirmado, PAULO AFONSO DE SOUZA SANT'ANNA entende que, visando a eliminar as dúvidas recursais existentes na vigência do CPC de 1939, o legislador em 1973 "classificou o ato judicial pela sua localização no processo e não mais pelo seu conteúdo, abandonando as determinações doutrinárias e científicas por um critério exclusivamente prático, no intuito de simplificar e dar unidade ao sistema de recursos, a fim de que as partes e os tribunais não mais fossem torturados pelo dilema de caber ou não o recurso, de ter havido ou não erro grosseiro, de estar ou não decidindo o mérito da
} 
Pois bem. No art. 162 foram listados os "atos do juiz", consubstanciados em sentenças, decisões interlocutórias e despachos. Contudo, é de se notar que o legislador foi impreciso ao empregar a expressão destacada, pois esta categoria abrange uma variedade de atos praticados pelo magistrado que não se resumem à exígua lista legal ${ }^{60}$, tais como: (i) oitiva de testemunhas; (ii) oitiva das partes; (iii) inspeção de pessoa ou coisa, (iv) exame do interditando, (v) arrecadação dos bens na herança jacente, etc. Tais atos são qualificados pela doutrina como materiais ${ }^{61}$, sendo irrelevantes do ponto de vista da recorribilidade, de modo que o indigitado dispositivo do Código de Processo Civil evidentemente quis se referir a apenas uma categoria de atos judiciais: os pronunciamentos ou provimentos ${ }^{62}$.

Necessário analisar como se estruturou o sistema de recursos à luz dos provimentos judiciais acima elencados.

Foram previstos pronunciamentos que não ensejariam qualquer interesse recursal, por serem desprovidos de conteúdo decisório. Trata-se dos despachos (art. 162, $\S 3^{\circ}$ ), atos judiciais meramente ordinatórios, destinados a desenvolver o andamento regular da marcha do processo $^{63}$. Como estão relacionados

causa. A classificação da sentença pelo seu efeito (encerrar o processo), e não pelo seu conteúdo, apenas teve o intuito de facilitar o sistema recursal" (cfr. "Sentença parcial", in MEDINA, José Miguel Garcia (coord.); CRUZ, Luana Pedrosa de Figueiredo (coord.); CERQUEIRA, Luiz Otávio Siqueira de (coord.); GOMES JR., Luis Manoel (coord.). Os poderes do juiz e o controle das decisões judiciais: estudos em homenagem à professora Teresa Arruda Alvim Wambier, RT, São Paulo, 2008, p. 456). v. tb. SICA, Heitor Vitor Mendonça. "Algumas implicações do novo conceito de sentença, de acordo com a Lei $n$. 11.232/2005", in CARMONA, Carlos Alberto (coord.). Reflexões sobre a reforma do Código de Processo Civil, Atlas, São Paulo, 2007, p. 188.

60 De acordo com CARlos AlBerto CARMONA, "mal entrou em vigor a nova Lei Processual, já começaram as críticas. Constatavam os doutrinadores, sem dificuldade, que nem todos os atos do juiz seriam classificáveis nas três categorias relacionadas no art. 162, já que o magistrado também pratica atos materiais (oitiva de testemunhas, inquirição de perito, tomada do depoimento das partes, inspeção judicial) e atos de documentação (assinatura de termos e cartas, por exemplo) que não se enquadravam em qualquer dos incisos do dispositivo legal mencionado" (cfr. "Ensaio sobre a sentença arbitral parcial”, in Revista de Processo, n. 165, RT, São Paulo, nov. 2008, p. 11).

${ }^{61}$ Segundo CÂNDIDO RANGEl DinAMARCO, os atos materiais não importam emissão de vontade pelo Estado-juiz (cfr. "Instituições de direito processual civil", v. II, $5^{\mathrm{a}}$ ed., Malheiros Editores, São Paulo, 2005, pp. 491-492).

${ }^{62}$ Cfr. BARBOSA MOREIRA, José Carlos. "Comentários ao Código de Processo Civil”, v. V, 10a ed., Forense, Rio de Janeiro, 2002, pp. 240-241.

${ }^{63}$ Não se desconhece a discussão doutrinária acerca da existência de duas espécies de despacho: despacho stricto sensu e despacho de mero expediente. Contudo, tendo em vista os objetivos propostos, deixa-se de analisá-la nesta sede, fazendo-se, contudo, a indispensável remissão à lição de BARBOSA MOREIRA sobre o tema (cfr. "Comentários ao Código de Processo Civil", v. V, 10ª ed., Forense, Rio de Janeiro, 2002, pp. 243-246). 
exclusivamente ao impulso processual, não possuem o condão de trazer qualquer dano a direito ou interesse das partes ${ }^{64}$, razão pela qual são irrecorríveis, nos termos do art. 504, do CPC. Identificado um provimento judicial sem cunho decisório, ou seja, um despacho, inexiste dúvida quanto ao recurso contra ele cabível: nenhum.

No tocante aos demais atos listados no art. 162, verifica-se um traço em comum: ambos são dotados de conteúdo decisório, de modo que seus efeitos repercutem na esfera jurídica das partes, podendo, assim, ser objeto de revisão através dos meios de impugnação disponíveis. E neste ponto se revela a importância em corretamente identificá-los, visto que vige no ordenamento processual pátrio o princípio da unirrecorribilidade (unicidade ou singularidade), pelo qual para cada decisão existe somente um único recurso cabível, sendo vedada a interposição de mais de um recurso contra a mesma decisão ${ }^{65}$.

Para diferenciá-los o legislador adotou critério topológico (localização ao final do processo) ${ }^{66}$ também chamado de finalístico (finalidade de extinguir o processo) ${ }^{67}$, cujo foco era a eficácia deles emanada ${ }^{68}$ (efeito de encerrar o processo). Diferentes signos para indicar o mesmo fenômeno: o abandono da anterior definição do ato (e do recurso adequado) pelo seu conteúdo para conceituá-lo com base em sua repercussão na continuidade do processo ${ }^{69}$.

\footnotetext{
${ }^{64}$ Cfr. THEODORO JUNIOR, Humberto. "Curso de direito processual civil”, v. I, $40^{\mathrm{a}}$ ed., Forense, Rio de Janeiro, 2003, p. 208.

${ }^{65}$ Cfr. DINAMARCO, Cândido Rangel. "Instituições de direito processual civil”, v. II, 5 a ed., Malheiros Editores, São Paulo, 2005, pp. 496-497; v. tb. BARBOSA MOREIRA, José Carlos. "Comentários ao Código de Processo Civil", v. V, $10^{\mathrm{a}}$ ed., Forense, Rio de Janeiro, 2002, pp. 248-251; JORGE, Flávio Cheim. "Teoria geral dos recursos cíveis", Forense, Rio de Janeiro, 2003, p. 180.

${ }^{66}$ Cfr. DINAMARCO, Cândido Rangel. "Instituições de direito processual civil", v. III, 5 a ed., Malheiros Editores, São Paulo, 2005, p. 655; BARBOSA MOREIRA, José Carlos. "Comentários ao Código de Processo Civil", v. V, $10^{\mathrm{a}}$ ed., Forense, Rio de Janeiro, 2002, p. 241; SICA, Heitor Vitor Mendonça. "Algumas implicações do novo conceito de sentença, de acordo com a Lei n. 11.232/2005", in CARMONA, Carlos Alberto (coord.). Reflexões sobre a reforma do Código de Processo Civil, Atlas, São Paulo, 2007, p. 187;OLIVEIRA, Bruno Silveira de. "Um novo conceito de sentença?" in Revista de Processo, n. 149, RT, São Paulo, julho de 2007, p. 121.

${ }^{67}$ Cfr. BUENO, Cássio Scarpinella. "A nova etapa da reforma do Código de Processo Civil: comentários sistemáticos às Leis n. 11.187, de 19-10-2005, e 11.232, de 22-12-2005”, v. 1, Saraiva, São Paulo, 2006, p. 14; VAREJÃO, José Ricardo do Nascimento. “As classificações, a lei 11.232/2005 e o 'novo' conceito de sentença", in WAMBIER, Teresa Arruda Alvim (coord.). Aspectos Polêmicos da Nova Execução, 3: de títulos judiciais, Lei 11.232/2005, RT, São Paulo, 2006, p. 372.

${ }^{68}$ Cfr. NEVES, Daniel Amorim Assumpção. "O novo conceito de sentença”, in Reforma do CPC: leis 11.187/2005, 11.232/2005, 11.276/2006, 11.276/2006 e 11.280/2006, RT, São Paulo, 2006, p.77.

${ }^{69}$ Não se pode olvidar a existência de posicionamento minoritário da doutrina, segundo o qual, mesmo após o advento do CPC de 1973, a definição de sentença continuou a ser fundada em seu conteúdo, devido à alusão do art. $162, \S 1^{\circ}$, ao julgamento com ou sem exame de mérito e à falta de coerência em se
} 
Nessa linha, o ato decisório que encerrava o processo foi definido como sentença, sendo característica irrelevante ter se dado a extinção do feito com ou sem julgamento de mérito ${ }^{70}$ (art. 162, $\S 1^{\circ}$ ). De outro lado, se o provimento fosse dotado de conteúdo decisório, mas não tivesse aptidão para extinguir o processo $^{71}$, estar-se-ia diante de decisão interlocutória ${ }^{72}$, pouco importando se a matéria objeto de apreciação envolvesse ou não o mérito da demanda ${ }^{73}$ (art. 162, $\S 2^{\circ}$ ). Na primeira hipótese o único recurso cabível seria o de apelação (art. 513); na segunda, seria interponível tão-somente o agravo (art. 522).

Deste modo, observa-se que o legislador introduziu uma espécie de provimento irrecorrível (sem cunho decisório), ao lado de duas modalidades recorríveis (com carga decisória). Para cada uma destas últimas, as quais se diferenciavam pela aptidão ou não de encerrar o processo, atribuiu um único recurso. Não foi contemplada terceira espécie de ato recorrível, circunstância alinhada ao objetivo de espancar as dúvidas ${ }^{74} \mathrm{e}$, consequentemente, conferir maior operabilidade ao sistema $^{75}$.

definir um objeto utilizando-se elemento que não lhe é integrante (no caso, a extinção do processo). Nesse sentido, TERESA ARRUDA AlVIM WAMBIER aduz ter sustentado"desde os últimos anos da faculdade, que se definir sentença como sendo o ato do juiz que põe fim ao processo está equivocado, errado. Jurídica e logicamente, não se pode escolher um critério que esteja fora do objeto definido para definir este objeto" (cfr. "O agravo e o conceito de sentença", in Revista de Processo, n. 144, RT, São Paulo, fevereiro de 2007, p. 253).

${ }^{70}$ Explica CÁSSIO SCARPINElla BuENo que "pela letra do art. 162, $\S 1^{\circ}$, na sua redação original, o critério empregado foi o da finalidade. Sentença é o ato que tem como finalidade encerrar o 'processo', 'pôr termo ao processo', como se lê do dispositivo, tenha, ou não, decidido o 'mérito da causa' (cfr. "A nova etapa da reforma do Código de Processo Civil: comentários sistemáticos às Leis n. 11.187, de 1910-2005, e 11.232, de 22-12-2005”, v. 1, Saraiva, São Paulo, 2006, p. 14).

${ }^{71}$ Cfr. THEODORO JUNIOR, Humberto. "Curso de direito processual civil", 40a ed., Forense, Rio de Janeiro, 2003, p. 207.

${ }^{72}$ Cfr. JORGE, Flávio Cheim. "Teoria geral dos recursos cíveis", Forense, Rio de Janeiro, 2003, p. 29.

${ }^{73}$ De acordo com TeRESA ARRUDA ALVIM WAMBIER, não é o conteúdo específico apresentado pelas interlocutórias "o que as distingue dos demais pronunciamentos judiciais, mas a natureza deste conteúdo, que tem que ser decisória" (cfr. "O novo regime do agravo". $2^{\mathrm{a}}$ ed., RT, São Paulo, 1996, pp. 72-74); v. tb THEODORO JUNIOR, Humberto. "O problema da recorribilidade das interlocutórias no processo civil brasileiro", disponível em http://www.abdpc.org.br/artigos/artigo47.htm, acessado em 7.7.11.

${ }^{74}$ Tanto é que o Código de 1973 não reproduziu a norma atinente à fungibilidade entre recursos, constante expressamente do CPC de 1939, em seu art. 810. Conforme explica BARBOSA MOREIRA, "o atual Código não reproduziu a regra, provavelmente por ter entendido o legislador que a sistemática adotada eliminaria a priori qualquer erro não grosseiro na escolha do recurso" (cfr. "Comentários ao Código de Processo Civil", v. V, $10^{\mathrm{a}}$ ed., Forense, Rio de Janeiro, 2002, p. 249).

${ }^{75}$ Dessa forma, é inegável a vantagem ofertada pelo antigo conceito de sentença, "qual seja, a perfeita e objetiva delimitação da recorribilidade por meio de apelação e, por exclusão, por meio de agravo. Não havia margem a dúvidas e não havia terceira hipótese" (cfr. VAREJÃO, José Ricardo do Nascimento. "As classificações, a lei 11.232/2005 e o 'novo' conceito de sentença", in WAMBIER, Teresa Arruda 
Não obstante a ordenação implementada, a opção do

Código foi criticada pela doutrina, tendo em vista que a realidade forense contrariava o dever-ser positivado pelo legislador ${ }^{76}$.

Apesar do texto legal expresso, a sentença não possuía ontologicamente o condão de necessária e efetivamente extinguir o processo. Isto porque a interposição de recurso fazia com que o processo novamente voltasse a correr perante o tribunal, sendo que o consequente acórdão a ser prolatado substituiria integralmente a sentença (art. 512, do CPC), de modo a advir a extinção do processo não do ato do juiz de primeiro grau, mas da última decisão prolatada em sede recursal ${ }^{77}$.

Além disso, ainda se não interposto recurso algum, era possível que o processo prosseguisse para a tomada de outras providências jurisdicionais necessárias à efetivação da sentença, como nas hipóteses de obrigação de fazer ou não fazer $^{78}$.

Alvim (coord.). Aspectos Polêmicos da Nova Execução, 3: de títulos judiciais, Lei 11.232/2005, RT, São Paulo, 2006, pp. 372-373).

${ }^{76}$ Sobre o ponto, CARMONA pondera que "era fácil de perceber que a sentença obviamente não punha fim ao processo, seja porque a parte, ao interpor recurso de apelação, fazia o processo correr de novo, seja porque havia providências jurisdicionais que o juiz deveria tomar depois da sentença para implementála, prosseguindo o ofício jurisdicional" (cfr. "Ensaio sobre a sentença arbitral parcial", in Revista de Processo, n. 165, RT, São Paulo, nov. 2008, p.11).

${ }^{77}$ Cfr. DINAMARCO, Cândido Rangel. "Instituições de direito processual civil", v. II, $5^{\mathrm{a}}$ ed., Malheiros Editores, São Paulo, 2005, p. 493.

${ }^{78}$ É cediço que "desde as Leis 8.952, de 13.12.1994, que deu nova redação ao art. 461 do CPC, acrescentando os $\$ \$ 1^{\circ}$ a $4^{\circ}$, e 10.444, de 07.05.2002, que deu nova redação ao $\$ 5^{\circ}$, acrescentou o $\$ 6^{\circ}$ e o art. 461-A e seus parágrafos, a sentença proferida em ação que tenha por objeto o cumprimento de obrigação de fazer ou não fazer ou a entrega de coisa, não põe fim ao procedimento de primeiro grau, eis que em qualquer dos casos, além de outras medidas, com fundamento no $\$ 5^{\circ}$ do art. 461, ao qual se reporta o $\$ 3^{\circ}$ do art. 461-A: 'para a efetivação da tutela específica ou a obtenção do resultado prático equivalente, poderá o juiz, de ofício ou a requerimento, determinar as medidas necessárias, tais como a imposição de multa por tempo de atraso, busca e apreensão, remoção de pessoas e coisas, desfazimento de obras e impedimento de atividade noviça, se necessário com requisição de força policial. Ou seja, a sentença não põe fim ao processo, pois ele prossegue para tornar efetiva a prestação da tutela jurisdicional" (cfr. VARGAS, Jorge de Oliveira. "O novo conceito de sentença e o recurso daquela que não extingue o processo: apelação ou agravo de instrumento?,in Revista de Processo, n. 148, RT, São Paulo, junho de 2007, p. 115); v. tb. NEVES, Daniel Amorim Assumpção. "O novo conceito de sentença", in Reforma do CPC: leis 11.187/2005, 11.232/2005, 11.276/2006, 11.276/2006 e 11.280/2006, RT, São Paulo, 2006, pp. 77-79; SANT'ANNA, Paulo Afonso de Souza. "Sentença parcial", in MEDINA, José Miguel Garcia (coord.); CRUZ, Luana Pedrosa de Figueiredo (coord.); CERQUEIRA, Luiz Otávio Siqueira de (coord.); GOMES JR., Luis Manoel (coord.). Os poderes do juiz e o controle das decisões judiciais: estudos em homenagem à professora Teresa Arruda Alvim Wambier, RT, São Paulo, 2008, pp. 458-459; POITTEVIN, Ana González. "Recorribilidade das decisões interlocutórias", Juruá, Curitiba, 2008, p. 16. 
Dessa forma, afirmou-se que, tecnicamente, o processo somente se extinguiria com o trânsito em julgado da decisão (sentença, acórdão ou até mesmo decisão monocrática em grau recursal) que determinasse tal providência ${ }^{79}$.

Em razão das críticas expostas, ponderou a doutrina ser mais adequado entender a extinção do processo como o potencial principal efeito da sentença, ou, então, que tal provimento teria o condão de, ao menos, encerrar o procedimento em primeiro grau de jurisdição ${ }^{80}$.

Ora, apesar dos defeitos e imperfeições notadamente existentes, o conceito desenhado pelo legislador de 1973 atendeu à função para a qual foi construído, simplificando o sistema de recursos ${ }^{81}$. No mais, o critério topológico adotado mostrava-se plenamente compatível no plano teórico com o modelo de resolução de conflitos existente, que se fundava na total separação das atividades de cognição e de execução em processos autônomos. Obtida a sentença no processo cognitivo, este era por tal ato encerrado.

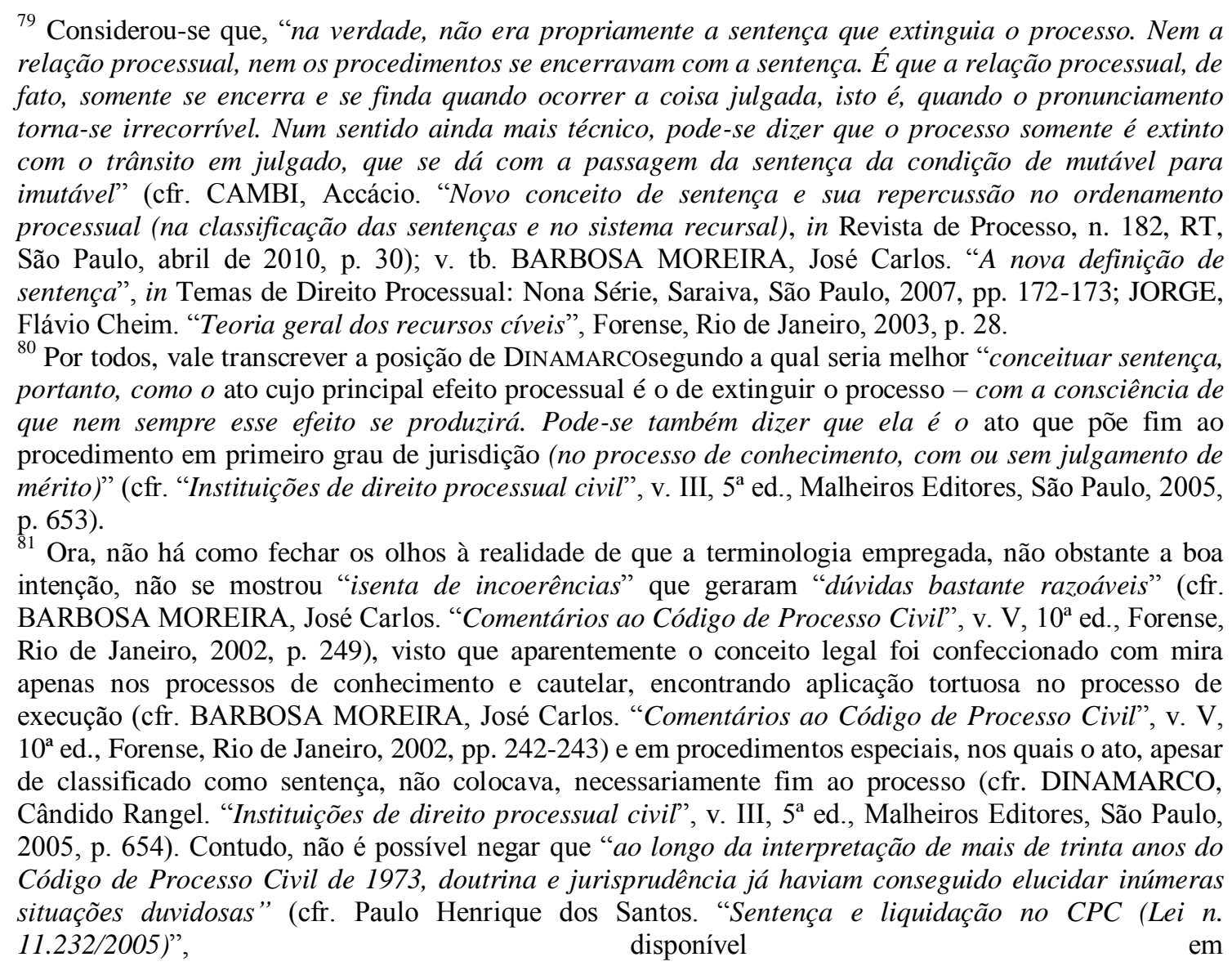
http://novo.direitoprocessual.org.br/fileManager/Paulo_Lucon__Sentena_e_liquidao_no_CPC.doc, acessado em 6.6.11, pp. 1-2). 
Diante disso, de rigor o ajuizamento de outra ação, originando nova relação jurídica processual, desta vez destinada à prática dos atos materiais imprescindíveis à satisfação do direito judicialmente reconhecido, cujo procedimento novamente culminava em sentença, a qual, por sua vez, extinguia o processo de execução de título judicial ${ }^{82}$, atendendo-se, por meio de trabalhoso, porém, consagrado método, aos escopos do processo.

Sendo assim, à luz da premissa fixada no item anterior, o conceito de sentença na redação original do Código de Processo Civil de 1973 tinha como significado o pronunciamento judicial que importava na extinção do processo, independentemente do resultado obtido (exame ou não de mérito), visto que tal construção atendia ao objetivo de simplificação do sistema recursal, dividindo os atos recorríveis em duas categorias estanques e impugnáveis por meios individualizados e bem definidos, guardando, ainda, relação de compatibilidade com o modelo de processo existente, tido até então como o método de trabalho mais adequado à solução de litígios.

As considerações até aqui realizadas tornam possível a fixação de outra premissa: é consequência lógica e inexorável deste sistema a possibilidade de existência de apenas uma sentença por processo, visto que tal ato, ao menos em tese, tinha o condão de, necessariamente, extingui-lo.

Ocorre que, com a evolução do pensamento processualístico, alteraram-se os paradigmas. Aos poucos a doutrina começou a considerar que o modelo até então existente não mais satisfazia de forma adequada e suficiente a missão conferida constitucionalmente ao Judiciário. Fez-se necessária mudança, que veio consubstanciada na Lei n. 11.232/2005.

\footnotetext{
${ }^{82}$ Tratava-se do denominado "princípio da autonomia", pelo qual o processo executivo era ente à parte, ao lado dos processos de cognição e cautelar. (cfr. ASSIS, Araken de. "Manual do processo de execução", $8^{\mathrm{a}}$ ed., RT, São Paulo, 2002, pp. 113-114).
} 


\subsection{LEI 11.232/05}

A reforma de 2005 introduziu no sistema processual brasileiro novel forma de efetivação da tutela condenatória por obrigação de pagar quantia em dinheiro. Visando a conferir maior efetividade ao método de solução de conflitos estatal, o legislador eliminou a dicotomia até então existente, consubstanciada na rígida separação entre cognição e execução em processos autônomos. Tais atividades agora são praticadas em diferentes fases dentro do mesmo processosincrético, sem solução de continuidade da relação jurídica processual.

A concepção de sentença prevista pelo legislador de 1973 tornou-se anacrônica, visto que, à luz do modelo a ser implementado, haveria hipóteses em que o provimento judicial não mais poderia-sequer no plano teórico-encerrar o processo de conhecimento, sob pena de contradição lógica com o novo sistema. Nessa linha, imaginou o legislador quais seriam as situações em que tal incompatibilidade se verificaria e tratou de alterar o conceito de sentença a fim de adaptá-lo a esta estrutura.

Sendo assim, a classificação dos provimentos judiciais existente se mostrou defasada em relação ao modelo de método de trabalho tido pelo Legislativo como mais adequado, de modo que a Lei n. 11.232/2005 modificou a redação do art. $162, \S 1^{\circ}$, do Código de Processo Civil, estabelecendo sentença como " $o$ ato do juiz que implica alguma das situações previstas nos arts. 267 e 269 desta Lei". Deixou-se de prevê-la como o pronunciamento judicial com aptidão para necessariamente extinguir o processo ("ato do juiz que põe termo ao processo"), passando-se a identificá-la como o provimento do juiz que possui determinado conteúdo.

Dessa forma, extirpou-se da definição de sentença a inafastável eficácia extintiva que lhe era conferida pela lei, com o objetivo de harmonizá-la ao modelo processual instituído, o qual não mais supõe a divisão da declaração do direito e de sua efetivação em processos autônomos ${ }^{83}$. Abandonou-se o

\footnotetext{
${ }^{83}$ Segundo Donaldo ARMELIN, “essa alteração descartou do conceito de sentença a necessária eficácia extintiva da relação processual, que lhe era conotada na redação modificada. Isto propiciou a harmonização do conceito de sentença com a nova estrutura do processo, que contempla sem solução de
} 
critério topológico para se classificar o ato através de seu conteúdo ${ }^{84}$, categorização que proporciona ao sistema inegável vantagem, consistente em sua compatibilidade lógica com o processo sincrético.

E, para espancar quaisquer dúvidas acerca da alteração do critério utilizado na classificação dos provimentos judiciais com carga decisória, foi dada nova redação ao art. 463, do CPC, tendo sido dele excluída a regra de que, após prolatar a sentença, "o juiz cumpre e acaba o ofício jurisdicional". Objetivou-se, portanto, mostrar que através da sentença não mais ocorre o forçoso encerramento do processo, o qual deve ser considerado como um único ente, que vai desde a petição inicial até a realização concreta do direito reconhecido ${ }^{85}$.

Desse modo, o fenômeno da extinção do processo não mais é suficiente para identificar determinado pronunciamento judicial como sentença, visto que, encerrada a etapa cognitiva do processo sincrético, haverá seu prosseguimento na fase de cumprimento de sentença. Para que o ato judicial seja

continuidade a declaração em sentido lato, do direito e a sua efetivação mediante uma fase executiva adequada à plena satisfação do direito reconhecido na sentença" (cfr. "Notas sobre sentença parcial e arbitragem", in Revista de Mediação e Arbitragem, n. 18, julho a setembro de 2008, p. 276).

${ }^{84}$ Cfr. BARBOSA MOREIRA, José Carlos. "A nova definição de sentença" in Temas de direito processual: nona série, Saraiva, São Paulo, 2007,p. 172; v. tb. NEVES, Daniel Amorim Assumpção. " $O$ novo conceito de sentença", in Reforma do CPC: leis 11.187/2005, 11.232/2005, 11.276/2006, 11.276/2006 e 11.280/2006, RT, São Paulo, 2006, p. 79; CORTEZ, Cláudia Helena Poggio. "O novo conceito de sentença visto pelos tribunais" in Revista de Processo, n. 171, RT, São Paulo, maio de 2009, p. 283; REDONDO, Bruno Garcia. "Sentença parcial de mérito e apelação em autos suplementares" in Revista de Processo, n. 160, RT, São Paulo, junho de 2008,pp. 143-144; OLIVEIRA, Bruno Silveira de. "Um novo conceito de sentença?" in Revista de Processo, n. 149, RT, São Paulo, julho de 2007, p. 128; VAREJÃO, José Ricardo do Nascimento. "As classificações, a lei 11.232/2005 e o 'novo' conceito de sentença", in WAMBIER, Teresa Arruda Alvim (coord.). Aspectos Polêmicos da Nova Execução, 3: de títulos judiciais, Lei 11.232/2005, RT, São Paulo, 2006, p. 373; SICA, Heitor Vitor Mendonça. "Algumas implicações do novo conceito de sentença, de acordo com a Lei n. 11.232/2005", in CARMONA, Carlos Alberto (coord.). Reflexões sobre a reforma do Código de Processo Civil, Atlas, São Paulo, 2007, p. 188.

${ }^{85}$ Nesse sentido, CÁSSIO SCARPINElla BUENO afirma que "a modificação trazida para a redação dos arts. 162, $\S 1^{\circ}, 267$, caput, 269, caput, e 463, caput, justifica-se muito mais para deixar claro que a sentença não encerra mesmo o 'processo' e que, em função das modificações que passaram a ocupar as diversas 'letrinhas' do art. 475, o 'processo jurisdicional' deve ser pensando, interpretado e aplicado como uma coisa só, que tem início com a propositura da petição inicial (a inércia do Estado-juiz, da 'jurisdição', no sentido de ele dever ser provocado de alguma forma, mesmo que com vícios, parece ser ainda bastante forte, não obstante os avanços da doutrina processual) e que só tem término com a realização concreta do que tiver, perante o Estado-juiz, sido reconhecido como 'o' direito. Seja o direito do autor, porque é vencedor na demanda e realizada concreta e materialmente a sua pretensão (obtém do réu o pagamento da dívida não paga ou a entrega da mercadoria paga mas não entregue, por exemplo); seja o direito do réu porque ele é o vencedor na demanda (a ação é julgada improcedente) e, por este fato, a ele agregada a coisa julgada material, realiza-se também o seu direito" (cfr. "A nova etapa da reforma do Código de Processo Civil: comentários sistemáticos às Leis n. 11.187, de 19-102005, e 11.232, de 22-12-2005”, v. 1, Saraiva, São Paulo, 2006, pp. 15-16). 
classificado como tal, basta, em tese, que possua algum dos conteúdos previstos em lei, sendo de todo irrelevante o momento processual em que é proferido ${ }^{86}$.

Entretanto, como era de se esperar, tais implicações não foram aceitas com passividade pela doutrina, a qual se dividiu quanto à definição do que seria sentença de acordo com o novo conceito legal ${ }^{87}$, consequência natural advinda das modificações legislativas.

Formaram-se três principais correntes:

(i) o único objetivo da Lei n. 11.232/2005 ao modificar o conceito de sentença foi o de possibilitar a implantação do processo sincrético, de modo a não ter sido trazida alteração substancial na definição do ato, que ainda deve ser considerado como aquele que encerra a fase cognitiva do processo ${ }^{88}$;

\footnotetext{
${ }^{86}$ Cfr. OLIANI, José Alexandre Manzano. "Cumprimento da sentença interlocutória que condena ao pagamento de soma, de acordo com a Lei 11.232/05", in SANTOS, Ernane Fidélis (coord.); WAMBIER, Luiz Rodrigues (coord.); NERY JR., Nelson (coord.); WAMBIER, Teresa Arruda Alvim (coord.). Execução civil: estudos em homenagem ao professor Humberto Theodoro Júnior, RT, São Paulo, 2007, p. 173.

${ }^{87}$ Diante dos problemas oriundos da modificação do conceito de sentença, considerou-se ter sido mais adequado o legislador não tê-lo previsto no Código. Nessa linha, enfatizou ATHOS GuSMão CARNEIRO que "a definição agora adotada suscitará críticas; todavia, impende reconhecer a dificuldade em conceituar 'sentença'. Talvez houvesse sido melhor que o Código definisse apenas o despacho e a decisão interlocutória, deixando à doutrina a definição de sentença" (cfr. "Do 'cumprimento da sentença', conforme a Lei n. 11.232/2005. Parcial retorno ao medievalismo? Por que não?" in Revista do Advogado, n. 85, AASP, São Paulo, maio de 2006, p. 33).

${ }^{88}$ Cfr. BARBOSA MOREIRA, José Carlos. "A nova definição de sentença", in Temas de Direito Processual: Nona Série, Saraiva, São Paulo, 2007, p. 177; BUENO, Cássio Scarpinella. "A nova etapa da reforma do Código de Processo Civil: comentários sistemáticos às Leis n. 11.187, de 19-10-2005, e 11.232, de 22-12-2005", v. 1, Saraiva, São Paulo, 2006, p. 17; THEODORO JUNIOR, Humberto. "As novas reformas do Código de Processo Civil", Forense, Rio de Janeiro, 2006, pp. 4-6;MARINONI, Luiz Guilherme; ARENHART, Sérgio Cruz. "Manual do processo de conhecimento", $5^{\mathrm{a}}$ ed., RT, São Paulo, 2006, p. 536; MARTINS, Renato Castro Teixeira. "Apelação por instrumento", in MEDINA, José Miguel Garcia (coord.); CRUZ, Luana Pedrosa de Figueiredo (coord.); CERQUEIRA, Luiz Otávio Siqueira de (coord.); GOMES JR., Luis Manoel (coord.). Os poderes do juiz e o controle das decisões judiciais: estudos em homenagem à professora Teresa Arruda Alvim Wambier, RT, São Paulo, 2008, p. 841; MARTINS, Sandro Gilbert. "Reflexos do novo conceito de sentença (CPC, art. 162, § 1', com a redação dada pela Lei n. 11.232/2005)", in Revista de Processo, n. 163, RT, São Paulo, setembro de 2008, p. 310; SOUZA, Gelson Amaro de; FILHO, Gelson Amaro de Souza. "Sentença - Em busca de uma nova definição" in Repertório de Jurisprudência IOB, n. 5, IOB, São Paulo, $1^{\text {a }}$ quinzena de março de 2009, pp 195-196; CENCI, Fábio; SOUZA, MARCHI, Paola M. Casagrande. "Novo (novo?) conceito de sentença", in Revista Bonijuris, n. 557, Instituto de Pesquisas Jurídicas Bonijuris, Curitiba, abril de 2010, p. XXVII; FRIAS, Jorge Eustácio da Silva. "A multa pelo descumprimento da condenação em quantia certa e o novo conceito de sentença", in Revista dos Tribunais, v. 858, abril de 2007, p. 76; LAZARI, Rafael José Nadim; SOUZA, Gelson Amaro de. "Breves apontamentos sobre a apelação por instrumento", disponível

em http://www.abdpc.org.br/abdpc/artigos/Breves\%20Apontamentos\%20sobre\%20a\%20Apela\%C3\%A7\%C $3 \% \mathrm{~A} 30 \% 20$ por\%20Instrumento\%20-
} 
(ii) a Lei n. 11.232/2005 representou modificação

substancial no conceito de sentença, que agora passa a ser classificado por seu conteúdo, sendo irrelevante para sua definição a noção de eficácia extintiva, seja do processo, seja de fase processual $^{89}$;

(iii) a Lei n. 11.2332/2005 não modificou o conceito de sentença terminativa, visto que esta ainda tem o condão de extinguir o processo, mas, por sua vez, trouxe alteração substancial em relação à sentença de mérito, a qual passou a ser definida exclusivamente por seu conteúdo, independentemente de qualquer eficácia extintiva ${ }^{90}$.

\%20Rafael\%20Jos\%C3\%A9\%20Nadim\%20de\%20LAZARI\%20e\%20Gelson\%20Amaro\%20de\%20SO UZA.pdf, acessado em 28.6.11, p. 9; LUCCA, Rodrigo Ramina de. "Antecipação de tutela da parcela incontroversa do mérito $e$ o conceito de sentença", disponível em http://www.abdpc.org.br/abdpc/artigos/Rodrigo\%20Ramina\%20de\%20Lucca.pdf, acessado em 28.6.11, pp. 13-16; MONTEIRO FILHO, Ralpho Wando de Barros; LUZ, Rolando Maria da. "O novo conceito de sentença", in Atualidade do Processo Civil, vol. I, ABDR, São Paulo, 2007, pp. 150-151; MACHADO, Daniel Carneiro. "O novo conceito de sentença e a natureza jurídica do ato judicial que resolve questões incidentais.", in Revista do Tribunal Regional da $1^{\text {a }}$ Região, v. 22, n. 4, abril de 2010, disponível em http://bdjur.stj.jus.br/xmlui/bitstream/handle/2011/34805/novo_conceito_senten\%C3\%A7a_machado.pdf ?sequence $=1$, acessado em 9.7.11, p. 7; VAREJÃO, José Ricardo do Nascimento. "As classificações, a lei 11.232/2005 e o 'novo' conceito de sentença”, in WAMBIER, Teresa Arruda Alvim (coord.). Aspectos Polêmicos da Nova Execução, 3: de títulos judiciais, Lei 11.232/2005, RT, São Paulo, 2006, p. 391; GRECO, Leonardo. "Primeiros comentários sobre a reforma da execução oriunda da Lei $n$. 11.232/05" in Revista do Advogado, n. 85, AASP, São Paulo, maio de 2006, p. 99.

${ }^{89} \mathrm{Cfr}$. SICA, Heitor Vitor Mendonça. "Algumas implicações do novo conceito de sentença, de acordo com a Lei n. 11.232/2005", in CARMONA, Carlos Alberto (coord.). Reflexões sobre a reforma do Código de Processo Civil, Atlas, São Paulo, 2007, p. 197; OLIVEIRA, Bruno Silveira de. "Um novo conceito de sentença?" in Revista de Processo, n. 149, RT, São Paulo, julho de 2007, p. 124; REDONDO, Bruno Garcia. "Sentença parcial de mérito e apelação em autos suplementares" in Revista de Processo, n. 160, RT, São Paulo, junho de 2008, pp. 143-145; SANT’ANNA, Paulo Afonso de Souza. "Sentença parcial", in MEDINA, José Miguel Garcia (coord.); CRUZ, Luana Pedrosa de Figueiredo (coord.); CERQUEIRA, Luiz Otávio Siqueira de (coord.); GOMES JR., Luis Manoel (coord.). Os poderes do juiz e o controle das decisões judiciais: estudos em homenagem à professora Teresa Arruda Alvim Wambier, RT, São Paulo, 2008, p. 460; AYOUB, Luiz Roberto; PELLEGRINO, Antônio Pedro. "A sentença parcial", in Revista de Arbitragem e Mediação, n. 22, RT, São Paulo, julho-setembro de 2009, pp. 46-48; MILMAN, Fabio. "O novo conceito legal de sentença e suas repercussões recursais: primeiras experiências com a apelação por instrumento", in Revista de Processo, n. 150, RT, São Paulo, agosto de 2007, p. 165; SCARPARO, Eduardo Kochenborger. "Sentenças parciais? Considerações a partir da reforma do art. 162, $\$ 1^{o}$, do Código de Processo Civil", disponível em http://www.scarparo.adv.br/artigos/sent.pdf, acessado em 6.6.11, pp. 12-13; VARGAS, Jorge de Oliveira. "O novo conceito de sentença e o recurso daquela que não extingue o processo: apelação ou agravo de instrumento?", in Revista de Processo, n. 148, RT, São Paulo, junho de 2007, p. 117.

${ }^{90} \mathrm{Cfr}$. BEDAQUE, José Roberto dos Santos. "Algumas considerações sobre o cumprimento da sentença condenatória", in Revista do Advogado, n. 85, AASP, São Paulo, maio de 2006, pp. 71-72; ARMELIN, Donaldo. "Notas sobre sentença parcial e arbitragem", in Revista de Mediação e Arbitragem, n. 18, julho a setembro de 2008, pp. 276 e 282; NEVES, Daniel Amorim Assumpção. "O novo conceito de sentença de mérito e os problemas recursais", in BRUSCHI, Gilberto Gomes (coord.); SHIMURA, Sérgio (coord.). Execução civil e cumprimento de sentença, vol. 2, Método, São Paulo, 2007, pp. 74-75; OLIANI, José Alexandre Manzano. "Cumprimento da sentença interlocutória que condena ao 
A principal consequência advinda da adoção de um ou de outro entendimento reside na possibilidade de prolação de sentenças parciais ao longo do procedimento. Se o inevitável encerramento do processo deixou de figurar entre os efeitos produzidos pelo ato judicial em tela, ter-se-ia tornado logicamente viável - e, como se verá, processualmente desejável - a existência de mais de uma sentença dentro do mesmo processo $^{91}$.

Destarte, se de fato o legislador removeu o óbice que, via de regra, tornava impossível classificar mais de uma decisão dentro do mesmo processo como sentença, e inexistindo impedimento legal e incompatibilidade teórica com o sistema, poderia o juiz proferir tantas decisões com conteúdo apto a qualificá-las como sentença quantas fossem necessárias ao longo do procedimento.

No entanto, tal possibilidade é veementemente negada pelo primeiro - e, ao que tudo indica, majoritário - dos posicionamentos acima expostos. De acordo com esta parcela da doutrina, o fracionamento do julgamento do objeto do processo mediante a prolação de sentenças parciais ao longo do procedimento não é admissível à luz de uma interpretação sistemática do Código de Processo Civil. Isto porque contra cada uma de tais decisões seria interponível o recurso de apelação, o qual implicaria a remessa dosautos do processo ao tribunal, gerando situação de inaceitável balbúrdia processual ${ }^{92}$.

Diante disso, para manter o conceito de sentença coerente com o sistema recursal estruturado - o qual restou intocado por esta reforma -,

pagamento de soma, de acordo com a Lei 11.232/05", in SANTOS, Ernane Fidélis (coord.); WAMBIER, Luiz Rodrigues (coord.); NERY JR., Nelson (coord.); WAMBIER, Teresa Arruda Alvim (coord.). Execução civil: estudos em homenagem ao professor Humberto Theodoro Júnior, RT, São Paulo, 2007, pp. 173-174.

91 Cfr. NEFFA JUNIOR, José Antônio. “Acesso à justiça e recorribilidade imediata das decisões interlocutórias em primeiro grau de jurisdição", disponível em http://www.fdv.br/mestrado/dissertacoes/Jose\%20Antonio\%20Neffa\%20Junior.pdf, acessado em 11.7.11, p. 59; v. tb. OLIVEIRA, Bruno Silveira de. "Um Novo Conceito de Sentença?", in Revista de Processo $\mathrm{n}^{\circ}$ 149, julho de 2007, p. 125.

92 Esse cenário caótico de perturbação da ordem processual, no qual seria necessário remeter os autos ao tribunal a cada apelação interposta, acabaria por implicar gravíssima ofensa à garantia constitucional da razoável duração do processo (art. 5, LXXVIII, da CF) (cfr. MARTINS, Sandro Gilbert. "Reflexos do novo conceito de sentença (CPC, art. 162, § $1^{\circ}$, com a redação dada pela Lei $n$. 11.232/2005)", in Revista de Processo, n. 163, RT, São Paulo, setembro de 2008, p. 311). 
sustentou-se a manutenção da eficácia extintiva na construção da noção de sentença, sendo necessário à decisão, para que pudesse ser classificada como tal, encerrar, ao menos, a fase cognitiva do procedimento. Sendo assim, não teria havido qualquer alteração substancial no conceito de sentença, pois a modificação de redação trazida pela Lei n. 11.232/2005 nada mais objetivou que compatibilizar a definição do ato com o processo sincrético introduzido ${ }^{93}$.

A definição positivada teria sido alterada somente para ser adaptada ao novo modelo de processo de conhecimento/execução ${ }^{94}$. A admissão de prolação de sentenças parciais traria sério e nocivo impacto ao sistema de recursos do Código, jamais tendo sido intenção do legislador modificá-lo, razão por que o ato somente poderá ser classificado como sentença se tiver por conteúdo uma das hipóteses dos artigos 267 e 269, do CPC, e, além disso, esgotar - ou ter aptidão para fazê-lo caso não interposto recurso - o acertamento do direito. Se algo mais, excetuando-se a liquidação, tiver que ser realizado, o ato não será sentença, mas mera decisão interlocutória ${ }^{95}$.

Ademais, o art. 162, $\S 1^{\circ}$, do CPC remete aos artigos 267 e 269 do Código, os quais continuam insertos no Capítulo III de seu Título VI, intitulado "Da extinção do processo" ${ }^{96}$, de modo que seria possível se concluir não ter a Lei n.

\footnotetext{
${ }^{93}$ A prolação da sentença não implica extinção do processo ou esgotamento da função jurisdicional, nada mais significando que o encerramento de uma fase processual, segundo afirma CÁsSIo SCARPINELLA BUENO: "com a reforma empreendida pela Lei $n, 11.232 / 05$, os arts. 162, $\$ 1^{\circ}$, 267, caput, 269, caput, $e$ 463, caput, tiveram sua redação alterada para deixar claro que o proferimento da sentença é, tão somente, a finalização de uma 'etapa', de uma 'fase' do 'processo jurisdicional' e que a sentença não significa - e não deve significar - que o 'processo' encerrou-se e, mais ainda, que o juízo possa considerar que tenha prestado sua atividade jurisdicional como, antes do novo diploma legal, lia se no caput do art. 463" (cfr. "A nova etapa da reforma do Código de Processo Civil: comentários sistemáticos às Leis n. 11.187, de 19-10-2005, e 11.232, de 22-12-2005”, v. 1, Saraiva, São Paulo, 2006, p. 17).

${ }^{94}$ Nessa linha, a exposição de motivos da Lei n. 11.232/2005 deixa claro seu escopo único de tornar viável a adoção do processo sincrético, demonstrando "a nítida intenção do legislador de adotar uma visão mais ampla e finalística do processo, considerando como seu verdadeiro objetivo a satisfação completa e real do direito, sendo a sentença, dentro deste novo contexto normativo, o ato judicial que encerra uma das etapas do processo, sem interromper a atividade jurisdicional" (cfr. MACHADO, Daniel Carneiro. "O novo conceito de sentença e a natureza jurídica do ato judicial que resolve questões incidentais.", in Revista do Tribunal Regional da $1^{a}$ Região, v. 22, n. 4, abril de 2010, disponível em http://bdjur.sti.jus.br/xmlui/bitstream/handle/2011/34805/novo_conceito_senten\%C3\%A7a_machado.pdf ?sequence $=1$, acessado em 9.7.11, p. 84).

${ }^{95}$ Cfr. FRIAS, Jorge Eustácio da Silva. "A multa pelo descumprimento da condenação em quantia certa e o novo conceito de sentença", in Revista dos Tribunais, v. 858, abril de 2007,p. 76.

${ }^{96}$ De acordo com tal argumentação, a "nova redação, apesar dos elogios que possa merecer, em nada altera a velha concepção de sentença como ato por meio do qual o Juiz encerra o processo. Assim era antes e continua sendo agora, depois da reforma pela Lei n. 11.232/05. A moderna redação do art. 162, $\S$
} 
11.232/3005 equiparado às sentenças os atos judiciais que apreciam questões incidentalmente, os quais continuam a ser classificados como decisões interlocutórias.

Tal constatação é reforçada pela própria reforma, que no art. 473-M, $\S 3^{\circ}$, do Código de Processo Civil, estabelece que a decisão que resolve a impugnação ao cumprimento de sentença é recorrível por agravo de instrumento, salvo se extinguir o processo, hipótese em que é cabível apelação ${ }^{97}$. Assim, o viés finalístico ainda persistiria no sistema, não tendo o legislador promovido qualquer alteração na redação do art. $162, \S 2^{\circ}$, do Código.

Essa circunstância, aliada ao fato de que continuaram sendo apenas duas as espécies de provimento judicial com conteúdo decisório, fez com que se ventilasse não ter havido, na verdade, substituição dos critérios utilizados para se conceituar sentença, mas tão-somente o acréscimo de mais um, o conteúdo do ato, ao já - e ainda - existente critério topológico ${ }^{98}$.

$1^{\circ}$, do CPC, ao fazer referência aos arts. 267 e 269, rodou e caiu no mesmo lugar. Os arts. 267 e 269 estão inseridos no Capítulo III do Título VI que cuida exatamente da extinção do processo. O Capítulo III congrega os arts. 267, 268 e 269, todos voltadosà extinção do processo. Logo, se a sentença é ato que implica qualquer das situações dos arts. 267 e 269, do CPC, não resta dúvida de que está cuidando de extinção do processo, como expressamente dispõe o art. 267 e, implicitamente, o art. 269 do CPC" (cfr. SOUZA, Gelson Amaro de; FILHO, Gelson Amaro de Souza. "Sentença - Em busca de uma nova definição" in Repertório de Jurisprudência IOB, n. 5, IOB, São Paulo, $1^{\text {a }}$ quinzena de março de 2009, pp. 195-196).

${ }^{97}$ Nesse sentido, apesar de ser defensor do julgamento antecipado parcial da demanda e da quebra do dogma da unicidade da sentença, afirma MARINONI que "não foi intenção da lei autorizar a equiparação às sentenças de quaisquer atos judiciais que apreciem o mérito, incidentalmente. Tais atos continuam a ser qualificados como decisões interlocutórias, sujeitando-se ao recurso de agravo. Esta conclusão é corroborada pelo próprio texto da lei, já que, tratando da impugnação ao cumprimento da sentença que deixa de ter natureza de processo incidental (embargos) para assumir a conotação de defesa interna ao processo -, esclarece que 'a decisão que resolver a impugnação é recorrivel mediante agravo de instrumento, salvo quando importar extinção da execução, caso em que caberá apelação" (cfr. MARINONI, Luiz Guilherme; ARENHART, Sérgio Cruz. "Manual do processo de conhecimento", 5 a ed., RT, São Paulo, 2006., p. 536); v. tb. cfr. VAREJÃO, José Ricardo do Nascimento. "As classificações, a lei 11.232/2005 e o 'novo' conceito de sentença", in WAMBIER, Teresa Arruda Alvim (coord.). Aspectos Polêmicos da Nova Execução, 3: de títulos judiciais, Lei 11.232/2005, RT, São Paulo, 2006, p. 392).

${ }^{98}$ Como o CPC prevê apenas duas espécies de atos judiciais decisórios, "os elementos classificatórios veiculados na conceituação de sentença repercutem na definição de decisão interlocutória e vice-versa". Dessa forma, tendo sido trazido o critério do conteúdo para a sentença e mantido o conceito de decisão interlocutória, "é inegável reconhecer-se (p. 382) que o critério finalístico remanesce no ordenamento, e não apenas se fazendo presente na definição das interlocutórias, mas de ambas as espécies decisórias. Não houve, portanto, uma substituição, mas sim o acréscimo de um segundo critério distintivo entre sentença e decisão interlocutória" (cfr. VAREJÃO, José Ricardo do Nascimento. "As classificações, a lei 11.232/2005 e o 'novo' conceito de sentença”, in WAMBIER, Teresa Arruda Alvim (coord.). Aspectos Polêmicos da Nova Execução, 3: de títulos judiciais, Lei 11.232/2005, RT, São Paulo, 2006, pp. 382383). 
Nessa linha, a definição de sentença e decisão interlocutória passou a ser dada por meio de dois critérios simultâneos ${ }^{99}$, de modo que a primeira seria todo provimento judicial que tivesse por conteúdo alguma das hipóteses previstas nos artigos 267 e 269, do CPC, e que não resolvesse questão incidente no curso do processo. Por sua vez, decisão interlocutória seria aquela que, sem implicar o conteúdo previsto no art. $162, \S 1^{\circ}$, do Código, solucionasse questão incidente sem extinguir o processo.

Como decorrência do afirmado, por mais inusitado possa parecer, a decisão interlocutória teria sido o provimento judicial a passar por maior alteração, pois a introdução do critério do conteúdo na sistemática fez com que tal ato não mais pudesse conter qualquer das hipóteses previstas artigos 267 e 269, do Código de Processo Civil ${ }^{100}$, exclusivas de abordagem via sentença ${ }^{101}$.

No entanto, a inclusão deste segundo critério distintivo trouxe a possibilidade lógica de uma terceira espécie de ato decisório: o pronunciamento

\footnotetext{
${ }^{99}$ Portanto, para a correta definição dos atos em tela, seria necessária sua adequação simultânea a dois critérios: "em função desse acréscimo e não substituição de critérios, ao percebermos que o conteúdo passou a ser nota positiva na conceituação de sentença (classe 'A'), temos que entender, da mesma forma, que também passou a influir na definição de decisão interlocutória, só que como nota negativa (classe '- $A$ '). O mesmo se diga, de forma inversa, em relação ao critério finalístico veiculado no $\$ 2^{\circ}$. Por outras palavras, a definição de cada espécie decisória passa a ser trabalho de adequação simultânea a dois critérios, sendo que em cada classe um estará presente (nota positiva) e o outro ausente (nota negativa)" (cfr. VAREJÂO, José Ricardo do Nascimento. "As classificações, a lei 11.232/2005 e o "novo' conceito de sentença", in WAMBIER, Teresa Arruda Alvim (coord.). Aspectos Polêmicos da Nova Execução, 3: de títulos judiciais, Lei 11.232/2005, RT, São Paulo, 2006, p. 383).

100 Nesse sentido afirma JosÉ RICARDO DO NASCIMENTO VAREJÃO: "verifica-se, em verdade que a sentença não sofreu qualquer alteração em sua definição, haja vista que é e sempre foi um provimento final e que veicula e sempre veiculou uma das matérias previstas nos arts. 267 e 269 do CPC, por imposição desses preceitos mesmos. Analisando-se bem a nova situação, verificaremos que, em realidade, o que de fato ocorreu foi aalteração do conceito de decisão interlocutória, porquanto a mesma é e sempre foi decisão que decide questão incidente ao processo, entretanto o seuconteúdo não era limitado às questões não reguladas pelos arts. 267 e 269 do CPC, como agora parece ocorrer" (cfr. "As classificações, a lei 11.232/2005 e o 'novo' conceito de sentença”, in WAMBIER, Teresa Arruda Alvim (coord.). Aspectos Polêmicos da Nova Execução, 3: de títulos judiciais, Lei 11.232/2005, RT, São Paulo, 2006, pp. 383-384).

Não obstante discorde da definição de sentença defendida por esta corrente e considere possível a prolação de sentenças parciais, HEITOR VITOR MENDONÇA SICA chegou a conclusão semelhante à ora transcrita quanto ao conceito de decisão interlocutória, afirmando que esta "será todo o provimento que, tendo cunho decisório, não implique situação dos artigos 267 e 269" (cfr. "Algumas implicações do novo conceito de sentença, de acordo com a Lei n. 11.232/2005”, in CARMONA, Carlos Alberto (coord.). Reflexões sobre a reforma do Código de Processo Civil, Atlas, São Paulo, 2007, p. 189).

${ }^{101}$ Considera JORGE DE OLIVEIRA VARGAS “que, em relação ao conteúdo, sentença é um ato que resolve o processo em qualquer das hipóteses dos arts. 267 e 269 do CPC, enquanto que decisão interlocutória, por exclusão, é o ato que resolve questões incidentes não compreendidas nas hipóteses antes citadas" (cfr. "O novo conceito de sentença e o recurso daquela que não extingue o processo: apelação ou agravo de instrumento?”, in Revista de Processo, n. 148, RT, São Paulo, junho de 2007, pp. 112-113).
} 
judicial que, no curso do processo e sem extingui-lo, possua como conteúdo alguma das hipóteses dos artigos 267 e 269, do CPC. Como o sistema recursal - e aqui novamente a crítica nele é fundada - não está dotado dos mecanismos adequados à impugnação deste provimento judicial, far-se-ia necessário realizar uma "reclassificação" do conceito de sentença, para, por meio de interpretação sistemática, dele afastar como critério distintivo preponderante o conteúdo, voltando-se os holofotes uma vez mais para sua eficácia extintiva.

Portanto, visando a evitar problemas na seara recursal, a sentença deve ser considerada apenas como o ato do juiz que encerra a primeira fase do processo em primeiro grau de jurisdição, servindo o critério do conteúdo tão-somente para confirmar a correta aplicação do critério topológico, ou seja, a necessidade de o provimento em tela veicular em seu bojo algum dos conteúdos específicos previstos em $\operatorname{Lei}^{102}$.

De acordo com o entendimento supra, a modificação substancial do conceito de sentença somente poderia ser acatada se acompanhada de reforma estrutural do Código, consistente na adaptação do sistema recursal e na alteração do conceito de decisão interlocutória ${ }^{103}$. Sem tais ajustes não é possível se falar em radical alteração na definição do ato, sob pena de tocar em ponto sensível do sistema de recursos vigente ${ }^{104}$.

\footnotetext{
102 Cfr. VAREJÃO, José Ricardo do Nascimento. “As classificações, a lei 11.232/2005 e o 'novo' conceito de sentença", in WAMBIER, Teresa Arruda Alvim (coord.). Aspectos Polêmicos da Nova Execução, 3: de títulos judiciais, Lei 11.232/2005, RT, São Paulo, 2006, pp. 385, 388 e 390-391.

${ }^{103}$ Assim sendo, "para que se aceite um novo conceito de sentença é necessário que haja uma reforma estrutural do CPC, adequando o sistema recursal aos novos tipos de decisão, bem como modificando o conceito de decisão interlocutória. Por enquanto, a nova redação do art. $161, \S 1^{\circ}$ não parece ter outra função senão a de autorizar, no mesmo processo, a fase de cumprimento de sentença" (cfr. LUCCA, Rodrigo Ramina de. "Antecipação de tutela da parcela incontroversa do mérito e o conceito de sentença", $\quad$ disponível em http://www.abdpc.org.br/abdpc/artigos/Rodrigo\%20Ramina\%20de\%20Lucca.pdf, acessado em 28.6.11, pp. 15-16).

${ }^{104}$ Por tal razão, afirma-se que a Lei 11.232/2005 não teve por escopo alterar a função de simplificação recursal atribuída pelo legislador de 1973 ao conceito de sentença, de modo que o caráter extintivo do ato ainda se mantém: "mas como o conceito codificado de sentença, a partir de 1973, e parece ter sido idêntica a intenção do legislador de 2005, teve como objetivo principal o de sepultar controvérsias quanto ao recurso cabível, pouco importa qual é o tipo de questão que a decisão examina, se processual oude mérito, o que interessa para a sua caracterização como sentença é se ela encerrou conclusivamente a fase cognitiva do processo" (cfr. GRECO, Leonardo. "Primeiros comentários sobre a reforma da execução oriunda da Lei n. 11.232/05" in Revista do Advogado, n. 85, AASP, São Paulo, maio de 2006, pp. 99-100).
} 
Em resumo, segundo esta corrente, embora a redação do dispositivo não faça menção expressa, o ato do juiz qualificado como sentença é tãosomente aquele que finaliza a etapa procedimental de cognição, e apenas dele será cabível recurso de apelação ${ }^{105}$.

Diante da importância das implicações deste ato judicial no que toca ao sistema recursal, não se pode aceitar haja se efetivado alteração significativa em seu conceito, tendo o legislador unicamente sinalizado que o pronunciamento em tela não mais tem o condão de extinguir o processo - agora sincrético -, apenas sendo dotado da capacidade de terminar sua fase cognitiva ${ }^{106}$.

Dessa forma, o ordenamento jurídico não admite o "fatiamento" da análise do objeto do processo por meio da prolação de sucessivas sentenças parciais ao longo do procedimento, visto que se o provimento não se manifestar acerca da integralidade dos pedidos deduzidos em juízo, relegando parcela da demanda para exame posterior, haverá mera decisão interlocutória ${ }^{107}$, visto que, em razão do não encerramento da fase processual, seriam incidentes as questões até então resolvidas $^{108}$.

\footnotetext{
${ }^{105}$ CÁSSIO SCARPINELla BuENO revela ser a preocupação, bem como o consequente raciocínio desenvolvido, decorrente da manutenção da integridade do sistema recursal: "deve-se ter em mente que o proferimento da sentença caracteriza-se, a despeito da nova letra do dispositivo, como o ato que encerra uma fase do procedimento em primeiro grau de jurisdição e que terá, necessariamente, um dos conteúdos dos arts. 267, caput, e 269, caput. E, por isto, por colocar fim a uma fase, a uma etapa, do procedimento em primeiro grau de jurisdição, é que dela caberá o recurso de apelação, de acordo com o art. 513" (cfr. "A nova etapa da reforma do Código de Processo Civil: comentários sistemáticos às Leis n. 11.187, de 19-10-2005, e 11.232, de 22-12-2005”, v. 1, Saraiva, São Paulo, 2006, p. 22).

${ }^{106}$ Cfr. GRECO, Leonardo. "Primeiros comentários sobre a reforma da execução oriunda da Lei $n$. 11.232/05" in Revista do Advogado, n. 85, AASP, São Paulo, maio de 2006, p. 99.

107 Cfr. BUENO, Cássio Scarpinella. "A nova etapa da reforma do Código de Processo Civil: comentários sistemáticos às Leis n. 11.187, de 19-10-2005, e 11.232, de 22-12-2005”, v. 1, Saraiva, São Paulo, 2006, p. 22.

${ }^{108}$ HumberTO THEODORO JÚNIOR assim sintetizou o referido entendimento: "Segundo penso, as 'situações previstas no art. 267 e 269' somente se prestam a configurar sentença (e a desafiar apelação) quando põem fim ao processo ou quando resolvem por inteiro o objeto principal do processo pendente de acertamento em juízo. Para o ato judicial cognitivo ser tratado como sentença é preciso que todo o pedido ou todos os pedidos da inicial tenham sido resolvidos, positiva ou negativamente. Se o pronunciamento não os abrange em toda a extensão, deixando questões para a solução no decisório final do processo, não pode ser havido como sentença. Sua natureza, dentro da lógica do sistema, é a de decisão interlocutória, ou seja, de ato que, no curso do processo, resolve 'questão incidente' (art. 162, $\S$ $2^{\circ}$ ). Pela insuficiência teórica e operacional do conceito de sentença formulado pelo $\$ 1^{o}$ do art. 162, sua real delimitação há de ser feita por exclusão: só se deverá considerar como sentença o ato decisório que não configurar decisão interlocutória. Se se resolve questão incidente (questão que não encerra o acertamento, nem põe fim à relação processual), o pronunciamento sobre qualquer tema dentre os previstos nos arts. 267 e 269 não assumirá a categoria de sentença; será decisão interlocutória, devendo
} 
Com a devida vênia ao posicionamento acima mencionado, não é possível com ele concordar, visto que a $\quad-$ conservadora interpretação defendida não se mostra correta, tendo em vista que ignora por completo a alteração legislativa havida, buscando manter em vigor regras revogadas pelo legislador $^{109}$.

Segundo já afirmado, a sentença não é categoria a ser considerada em abstrato, como ente autônomo, independentemente da ordem jurídica em que está inserta. Não é elemento presente na natureza dotado de significado próprio. Dessa forma, não é possível ao intérprete fugir dessa realidade, ignorando as alterações legislativas em razão de uma suposta maior conformidade de determinada exegese com o vigente sistema recursal ${ }^{110}$.

Nessa linha, apesar de a vontade do legislador não ter sido manifestada expressamente no sentido de permitir o fracionamento do julgamento do mérito (mens legislatoris), bem como a prolação de sentenças parciais, legemhabemus e dela devem os aplicadores do direito extrair a maior efetividade processual possível (mens legis) $^{111}$.

sua impugnação ocorrer por meio de agravo e não de apelação"(cfr. "As novas reformas do Código de Processo Civil", Forense, Rio de Janeiro, 2006,pp. 4-6).

109 Ora, "esta visão conservadora não parece ser sustentável, pois seus autores pretenderiam simplesmente manter em vigor um dispositivo revogado (qual seja, o $\$ 1^{\circ}$ do art. 162, em sua versão original)". Desse modo, ainda que discutível "permitir aos juizes que profiram tantas sentenças parciais quantas julgarem adequadas, de acordo com o paulatino amadurecimento da causa", inexiste dúvida de que "haverá certamente situações em que o juiz poderá, com vantagem, valer-se das sentenças parciais, devendo o sistema recursal ser adaptado à novidade" (cfr. CARMONA, Carlos Alberto. "Ensaio sobre a sentença arbitral parcial", in Revista de Processo, n. 165, RT, São Paulo, nov. 2008, p. 13).

${ }^{110}$ Esta é, também, a posição de HeITOR VITOR MENDONÇA SiCA: "com a mais elevada vênia, sentença não é elemento presente na natureza e portador de significado próprio, a ser simplesmente decifrado pela lei. Sentença é aquilo que a lei processual diz que é e por mais que seu novo conceito tenha vindo a lume de modo descuidado (porquanto e desacompanhado de alterações no sistema recursal), não há como fugir da inexorável realidade: a sentença é, hoje, definida pelo conteúdo. Se esse provimento encerra ou não a instância, isso não mais importa. E se daí surgirão problemas de ordem recursal, isso não autoriza o intérprete a desconsiderar o que está textualmente expresso no artigo $162, \S 1^{o}$, do Código de Processo Civil" (cfr. "Algumas implicações do novo conceito de sentença, de acordo com a Lei n. 11.232/2005", in CARMONA, Carlos Alberto (coord.). Reflexões sobre a reforma do Código de Processo Civil, Atlas, São Paulo, 2007, p. 201).

${ }^{111}$ O relato de CARLOS ALBERTO CARMONA é incisivo: "para quem imaginava que o legislador, como novo conceito do art. 162, § 1, estaria inaugurando a era das sentenças parciais, devo dizer que, durante as reuniões que os membros do Instituto Brasileiro de Direito Processual tivemos em Brasília no distante mês de agosto de 2003, o tema não foi efetivamente objeto de proposta concreta. Em outras palavras, o legislador objetivava a adaptação do conceito à nova realidade do cumprimento de sentenças, sem que houvesse a vontade política de permitir o 'fatiamento' do julgamento da lide, o que criaria 
O principal argumento dos que se negam a admitir o novo conceito do ato decisório em epígrafe reside na dificuldade de sua compatibilização com as características do sistema de recursos do Código, principalmente nos problemas decorrentes da admissão da interposição de sucessivas apelações diante da possibilidade de prolação de mais de uma sentença no mesmo processo.

Não obstante louvável a preocupação, tal circunstância não pode servir de argumento para sustentar interpretação manifestamente contrária à dicção do texto legal ${ }^{112}$, cabendo aos operadores do direito a tarefa de, com base nas regras processuais vigentes, encontrar solução aceitável.

Ora, não se mostra cientificamente correto realizar a classificação de determinado ato como sentença ou decisão interlocutória em função do recurso previsto pela lei como meio apto a impugná-lo ${ }^{113}$. Se o critério de identificação de um provimento jurisdicional fosse sua recorribilidade por apelação ou por agravo estar-se-ia diante de curioso cenário, no qual existiriam decisões que não se encaixariam em quaisquer dessas classes.

Não é necessária muita zetética para demonstrar tal assertiva. Sob esta ótica, indaga-se qual seria a natureza do ato do juiz que resolve

incompatibilidade com o sistema recursal do Código. Mas isso corresponderia, quem sabe, à mens legislatoris; a mens legis vem sendo interpretada de forma bem variada. [...] O Superior Tribunal de Justiça dirá, em tempo mais ou menos curto, a direção a seguir na interpretação do dispositivo legal renovado (art. 162, $\S 1^{\circ}$ ), estabelecendo - esperamos todos! - os parâmetros para o julgamento antecipado de parte da lide" (cfr. "Ensaio sobre a sentença arbitral parcial", in Revista de Processo, n. 165, RT, São Paulo, nov. 2008, p. 14).

${ }^{112}$ Indo ao encontro do afirmado, invoca-se opinião de DANIEL AMORIM AsSUMPÇão NEVES, segundo a qual "como se pode perceber das lições dos doutrinadores que se colocaram contra o novo conceito legal de sentença de mérito, a angústia maior reside no aspecto recursal, em especial na possibilidade de existência de inúmeras sentenças no mesmo processo, o que geraria em consequência inúmeras apelações, acarretando a eternização do procedimento e depondo claramente contra a celeridade processual, maior objetivo perseguido pelo legislador nas recentes alterações do Código de Processo Civil. Apesar de ser compreensível a preocupação com os problemas recursais, a simples negação da modificação legal não pode ser admitida, sob pena de evidente insegurança jurídica. A simples não concordância com os termos da lei não pode ser o suficiente para uma interpretação manifestamente contra legem, simplesmente porque o operador acredita que a determinação legal não se coaduna com aquilo que tal operador espera do ordenamento" (cfr. "O novo conceito de sentença de mérito e os problemas recursais", in BRUSCHI, Gilberto Gomes (coord.); SHIMURA, Sérgio (coord.). Execução civil e cumprimento de sentença, vol. 2, Método, São Paulo, 2007, p. 76).

${ }^{113}$ Cfr. CORTEZ, Cláudia Helena Poggio. "O novo conceito de sentença visto pelos tribunais" in Revista de Processo, n. 171, RT, São Paulo, maio de 2009, p. 285. 
execução fiscal de valor igual ou inferior a 50 (cinqüenta) Obrigações Reajustáveis do Tesouro Nacional - ORTN, considerando-se que o recurso contra ele cabível são os embargos infringentes (art. 34, da Lei n. 6.830/80). Sobre o ponto, ainda, pergunta-se: como identificar o pronunciamento judicial proferido no procedimento dos Juizados Especiais Cíveis, impugnável por recurso inominado (art. 41, da Lei n. 8.099/95) ${ }^{114}$ ?

Nesse sentido, o simples fato de a lei prever determinado recurso como cabível para contrariar um provimento judicial não tem o condão de reconhecê-lo necessariamente como sentença ou decisão interlocutória ${ }^{115}$, sendo perfeitamente possível que o Código estabeleça exceção à regra da correspondência recursal com base em juízo de especialidade, cuja incidência é justificável em razão das circunstâncias procedimentais em que é proferido ${ }^{116}$.

A recorribilidade do ato não pode condicionar sua classificação como uma ou outra espécie decisória, devendo esta ser feita à luz dos conceitos estabelecidos pelo legislador. De tal modo, ainda que não encerre fase procedimental, se determinada decisão se subsume à definição de sentença legalmente prevista, a constatação de eventual dificuldade em interpor recurso contra ela não tem o condão de transformá-la em interlocutória.

\footnotetext{
${ }^{114}$ Não obstante em ambos os dispositivos legais o legislador dê o nome de sentença ao provimento judicial, a partir do momento em que é possível flexibilizar o disposto no critério no art. $162, \S 1^{\circ}$, do CPC, a fim de desconsiderar a modificação nele introduzida pela Lei n. 11.232/2005, nada impede as indigitadas denominações legalmente estabelecidas sejam relidas à luz do critério de classificação por meio da recorribilidade do ato.

${ }^{115}$ Nessa mesma linha, o entendimento de DANIEL AMORIM AsSumpÇão Neves: "o cabimento de determinado recurso pela lei não desvirtua a natureza do pronunciamento recorrível, que deve ser determinado à luz de seu conceito legal, previsto no art. 162, do CPC. Ou seria defensável que o pronunciamento que decide a impugnação à concessão dos benefícios da assistência judiciária é uma sentença, somente porque a Lei 1.060/50, em seu art. 17, prevê o cabimento do recurso de apelação contra tal decisão?" (cfr. "O novo conceito de sentença de mérito e os problemas recursais", in BRUSCHI, Gilberto Gomes (coord.); SHIMURA, Sérgio (coord.). Execução civil e cumprimento de sentença, vol. 2, Método, São Paulo, 2007, pp. 83-84).

${ }^{116}$ Assim, "o fato de determinada decisão dever ser impugnada por agravo não deve, por si só, significar que referida decisão seja necessariamente interlocutória (art. 162, $\$ 2^{\circ}, C P C$ ). Ao contrário, dever-se-ia reconhecer que, a depender do conteúdo da decisão, tratar-se-ia de sentença excepcionalmente impugnável por agravo, em nítida relativização do princípio da correspondência, que, assim como todos os demais princípios, não é absoluto" (cfr. CORTEZ, Cláudia Helena Poggio. "O novo conceito de sentença visto pelos tribunais" in Revista de Processo, n. 171, RT, São Paulo, maio de 2009, p. 288).
} 
A existência da sentença parcial não pode ser atrelada aos meios cabíveis a sua impugnação ${ }^{117}$. Em outras palavras, a conclusão de que não houve alteração no conceito de sentença não pode advir de pretensa dificuldade no manejo de recurso de apelação contra a sentença parcial $^{118}$.

No mais, como reforço argumentativo, o próprio esforço de parcela da doutrina em manter a definição do ato com base no critério topológico, tal qual originalmente prevista no Código de 1973, sendo notável que se chegue até mesmo a considerar a antiga redação do art. 162, $\S 1^{\circ}$, como plenamente compatível com a nova sistemática processual introduzida $^{119}$, revela ser patente que a Lei n. 11.232/2005 trouxe modificação substancial ao conceito de sentença ${ }^{120}$.

Houve nítida substituição do critério finalístico pelo de conteúdo $^{121}$. Destarte, para que seja categorizado como sentença, basta ao provimento

117 Sobre a possibilidade de se admitir sentenças parciais no sistema, afirma SANDRO GILBERT MARTINS que "o aspecto que aqui merece relevo é o seguinte: para ser possível sustentar a existência de uma sentença parcial, é preciso, antes, entender que o conceito de sentença não deve ser atrelado ao de sua recorribilidade. Ou seja, as características do sistema recursal não podem infirmar a existência de uma sentença parcial" (cfr. "Reflexos do novo conceito de sentença (CPC, art. 162, § $1^{o}$, com a redação dada pela Lei n. 11.232/2005)", in Revista de Processo, n. 163, RT, São Paulo, setembro de 2008, p. 309).

${ }^{118}$ Das dificuldades na interposição de apelação não pode decorrer " a conclusão de que o conceito de sentença em nada tenha mudado. Como já o demonstramos, o conceito de sentença mudou e muito. Devemos, apenas, admitir a veracidade desse dado e lidar com suas consequências da melhor maneira possível. [...]Partir da premissa de que a apelação - na hipótese conjeturada - não pode subir nos próprios autos para chegar-se à conclusão de que o conceito de sentença não sofreu alteração de monta é, em suma, tomar a consequência pela causa" (cfr. OLIVEIRA, Bruno Silveira de. "Um novo conceito de sentença?" in Revista de Processo, n. 149, RT, São Paulo, julho de 2007, p. 133).

${ }^{119}$ Vale transcrever o argumento: "em verdade, sequer seria necessária uma alteração redacional para se lograr êxito na adequação do art. 162, $\$ 1^{\circ}$, à nova sistemática implementada. Bastava que se efetuasse uma interpretação evolutiva do preceito legal, a qual consiste na alteração norma, ou seja, do conteúdo de significação construído a partir do texto normativo, sem necessidade de modificação deste último. Essa mudança de interpretação, ao seu turno, pode advir das exigências promovidas por alterações das circunstâncias sociais, históricas ou mesmo jurídicas. Seria suficiente, portanto, uma simples releitura do enunciado normativo de acordo com a nova sistemática imposta" (cfr. VAREJÃO, José Ricardo do Nascimento. "As classificações, a lei 11.232/2005 e o 'novo' conceito de sentença", in WAMBIER, Teresa Arruda Alvim (coord.). Aspectos Polêmicos da Nova Execução, 3: de títulos judiciais, Lei 11.232/2005, RT, São Paulo, 2006, pp. 371-372 - nota de rodapé n. 8).

${ }^{120}$ Tal conclusão é sustentada por BRUNO SILVEIRA DE OlIVEIRA: "Imperioso, sob o ponto de vista da lógica, que saibamos separar as coisas: o problema do processamento da apelação é uma consequência do novo conceito de sentença, por isso mesmo, não implica e não pode implicar a manutenção do conceito antigo (pela razão óbvia de que, se o problema apontado existe, é porque um novo conceito de sentença passou a existir!)" (cfr. "Um novo conceito de sentença?" in Revista de Processo, n. 149, RT, São Paulo, julho de 2007, p. 133).

${ }^{121}$ Cfr. BARBOSA MOREIRA, José Carlos. "A nova definição de sentença" in Temas de direito processual: nona série, Saraiva, São Paulo, 2007,p. 172; NEVES, Daniel Amorim Assumpção. "O novo conceito de sentença”, in Reforma do CPC: leis 11.187/2005, 11.232/2005, 11.276/2006, 11.276/2006 e 11.280/2006, RT, São Paulo, 2006, p. 79; CORTEZ, Cláudia Helena Poggio. "O novo conceito de sentença visto pelos tribunais" in Revista de Processo, n. 171, RT, São Paulo, maio de 2009, p. 283; 
judicial veicular alguma das hipóteses específicas previstas em lei, resolvendo integral ou parcialmente a lide, já que irrelevante o momento processual em que é proferido ${ }^{122}$.

Ademais, se fracionado o julgamento da demanda, a parcela do mérito analisada não se transforma em questão incidente tão-somente em virtude de o exame não ter abrangido a integralidade do objeto trazido a juízo ${ }^{123}$.

Conforme se verá, a admissão do "fatiamento" do julgamento do mérito consiste em enorme avanço no campo da efetividade processual $^{124}$. Não obstante isso, entre os defensores da salutar modificação há uma leve divergência, no que tange à definição da sentença terminativa - a qual também gera reflexos no conceito de decisão interlocutória.

A parcela da doutrina que corretamente entende ter havido a inclusão do critério do conteúdo na definição dos provimentos judiciais é uníssona na

REDONDO, Bruno Garcia. "Sentença parcial de mérito e apelação em autos suplementares" in Revista de Processo, n. 160, RT, São Paulo, junho de 2008,pp. 143-144; OLIVEIRA, Bruno Silveira de. " $U m$ novo conceito de sentença?" in Revista de Processo, n. 149, RT, São Paulo, julho de 2007, p. 128; VAREJÃO, José Ricardo do Nascimento. “As classificações, a lei 11.232/2005 e o 'novo' conceito de sentença", in WAMBIER, Teresa Arruda Alvim (coord.). Aspectos Polêmicos da Nova Execução, 3: de títulos judiciais, Lei 11.232/2005, RT, São Paulo, 2006, p. 373); SICA, Heitor Vitor Mendonça. "Algumas implicações do novo conceito de sentença, de acordo com a Lei n. 11.232/2005", in CARMONA, Carlos Alberto (coord.). Reflexões sobre a reforma do Código de Processo Civil, Atlas, São Paulo, 2007, p. 188.

${ }^{122}$ Cfr. OLIANI, José Alexandre Manzano. “Cumprimento da sentença interlocutória que condena ao pagamento de soma, de acordo com a Lei 11.232/05", in SANTOS, Ernane Fidélis (coord.); WAMBIER, Luiz Rodrigues (coord.); NERY JR., Nelson (coord.); WAMBIER, Teresa Arruda Alvim (coord.). Execução civil: estudos em homenagem ao professor Humberto Theodoro Júnior, RT, São Paulo, 2007, p. 173.

123 Assevera PAULO SANT'ANNA que “para ser considerada sentença, a decisão não precisa ter apreciado a demanda em sua integralidade: basta que verse sobre as matérias previstas nos arts. 267 e 269, como expressa e, agora, corretamente prevê o $\$ 1^{\circ}$ do art. 162. O fato de ser proferida apenas sobre parte da demanda não altera seu objeto. O seu conteúdo (arts. 267 e 269) não se transmuda para 'questão incidente' apenas porque não decidiu todos os pedidos. É sentença, porém parcial. Em outros termos, não é porque a decisão é parcial que o conteúdo da decisão que trata das situações previstas nos arts. 267 e 269 se transforma em 'questão incidente'. A natureza da decisão não se altera apenas porquanto proferida no curso do processo. Será sentença a decisão que tiver por conteúdo os arts. 267 e 269 e será decisão interlocutória a decisão que resolver questão incidente (art. $162, \$ \S 1^{\circ}$ e $2^{\circ}$ ). A sentença não se transforma em decisão interlocutória somente porque não foi proferida no fim da fase de conhecimento do processo. É sentença, porém, parcial" (cfr. "Sentença parcial", in MEDINA, José Miguel Garcia (coord.); CRUZ, Luana Pedrosa de Figueiredo (coord.); CERQUEIRA, Luiz Otávio Siqueira de (coord.); GOMES JR., Luis Manoel (coord.). Os poderes do juiz e o controle das decisões judiciais: estudos em homenagem à professora Teresa Arruda Alvim Wambier, RT, São Paulo, 2008, p. 460).

${ }^{124}$ Cfr. MARTINS, Pedro Batista. "A arbitragem e o mito da sentença parcial”, in CARMONA, Carlos Alberto (coord.); LEMES, Selma Ferreira (coord.); MARTINS, Pedro Batista (coord.). Arbitragem: Estudos em Homenagem ao Prof. Guido Fernando da Silva Soares in memoriam, Atlas, São Paulo, 2007, p. 284 , nota de rodapé n. 37. 
identificação da sentença de mérito. Não obstante isso, tal harmonia não se verifica em relação à classificação da decisão do juiz que não analisa o mérito da demanda.

A disparidade de entendimentos decorre da redação conferida pela Lei n. 11.232/2005 aos artigos 267 e 269, os quais integram o conteúdo do conceito de sentença por força do art. 162, $\S 1^{\circ}$, do Código de Processo Civil.

O legislador substituiu a expressão "julgamento" no caput dos artigos 267 e 269 por "resolução". A doutrina considerou tal modificação positiva, pois, não obstante irrelevante do ponto de vista prático, tornou o texto legal mais preciso por englobar situações em que não havia julgamento de mérito propriamente dito $^{125}$. Todavia, houve quem considerasse tal modificação inapta a conferir maior clareza ao conceito $^{126}$, sendo que se afirmou ter sido negativa a inovação, pois substituiu, sem qualquer vantagem prática, termo já consagrado na doutrina e jurisprudência, o qual, ainda serve para identificar, no direito brasileiro, modalidade de ato administrativo ${ }^{127}$.

Além desta singela alteração, verifica-se que no tocante ao art. 269, a reforma eliminou os termos "extingue-se o processo", passando a constar que "haverá resolução de mérito" nas hipóteses que lista. De outro lado, não se operou a mesma alteração no art. 267, no qual o legislador optou por manter a noção de encerramento do processo, deixando intocada a expressão "extingue-se o processo".

Sendo assim, é possível se concluir que a divergência reside em se entender ter sido adotado um critério de conteúdo puro, aplicável tanto às sentenças definitivas quanto às terminativas, ou, se, ao revés, adotou-se definição

\footnotetext{
${ }^{125}$ Cfr. FRIAS, Jorge Eustácio da Silva. "A multa pelo descumprimento da condenação em quantia certa e o novo conceito de sentença", in Revista dos Tribunais, v. 858, abril de 2007,p. 72.

${ }^{126}$ Cfr. CARNEIRO, Athos Gusmão. "Do 'cumprimento da sentença', conforme a Lei n. 11.232/2005. Parcial retorno ao medievalismo? Por que não?" in Revista do Advogado, n. 85, AASP, São Paulo, maio de 2006, p. 33.

${ }^{127}$ Nesse sentido, considera BEDAQUEque o legislador "inovou para pior. Primeiro, porque a expressão não é usual na doutrina brasileira e a alteração não traz nenhuma vantagem prática. A redação original, além de consagrada, traduzia com fidelidade o correto significado do fenômeno. Também não há vantagem no emprego de palavra que, no Brasil, é utilizada para designar modalidade de ato administrativo" (cfr. "Algumas considerações sobre o cumprimento da sentença condenatória", in Revista do Advogado, n. 85, AASP, São Paulo, maio de 2006, p. 71).
} 
baseada em critério misto: conteúdo para sentenças definitivas e topológico para as sentenças terminativas.

A primeira corrente defende ter sido insatisfatória a reforma na alteração do caput do art. 267, pois o sistema processual não mais está fundado na divisão entre processo de conhecimento e de execução. Nessa linha, não há se falar em "extinção" do processo na definição do conceito de sentença, sob pena de se criar incoerência dentro do sistema sincrético estabelecido. Mais técnico seria, portanto, ter sido adotada a expressão "não há resolução de mérito", à semelhança do caput do art. 269, do Código ${ }^{128}$.

Ao manter a ideia de extinção do processo em relação à sentença terminativa o legislador cometeu equívoco, pois considerou que apenas as sentenças de mérito implicariam fase posterior de cumprimento. Ocorre que ao proferir decisão terminativa o juiz fixa as verbas de sucumbência, as quais serão executadas em etapa procedimental posterior. Dessa forma, mesmo em relação às sentenças processuais é impreciso se falar em encerramento do processo $^{129}$.

Diante disso, parte dos processualistas passou a afirmar que em homenagem à harmonia na definição de sentença, deveria ser considerada como tal o ato que tivesse como conteúdo algumas das hipóteses do art. 267, ainda que não houvesse extinção do processo. Invocando-se interpretação sistemática, a extinção a que se refere o caput do artigo não seria a do processo, mas sim do procedimento em relação a cada uma das questões nele discutidas ${ }^{130}$. Assim, a sentença passou a ser o ato que

\footnotetext{
${ }^{128}$ Cfr. REDONDO, Bruno Garcia. "Sentença parcial de mérito e apelação em autos suplementares" in Revista de Processo, n. 160, RT, São Paulo, junho de 2008, pp. 144-145.

${ }^{129} \mathrm{Cfr}$. SICA, Heitor Vitor Mendonça. "Algumas implicações do novo conceito de sentença, de acordo com a Lei n. 11.232/2005", in CARMONA, Carlos Alberto (coord.). Reflexões sobre a reforma do Código de Processo Civil, Atlas, São Paulo, 2007, pp. 196-197.

${ }^{130}$ JORGE DE OLIVEIRA VARGAS busca compatibilizar a ideia de extinção do processo contida no art. 267 com a classificação do conceito de sentença exclusivamente por meio do critério do conteúdo: "outro argumento que não pode ser desprezado é o de que o art. 267 continua a dizer que extingue-se o processo' sem resolução do mérito, nas hipóteses ali previstas. Aparentemente se mantém, neste aspecto, o conceito de sentença por força de seu efeito, qual seja, o de por fim ao processo, pelo menos em relação às hipóteses do art. 267. Entretanto não se pode fazer uma leitura isolada deste dispositivo, mas sistemática, da qual pode-se extrair que a redação do art. 267 se refere à extinção do procedimento e não do processo, e do procedimento em relação cada uma das partes, ou relativamente a cada uma das questões ali enumeradas" (cfr. "O novo conceito de sentença e o recurso daquela que não extingue o processo: apelação ou agravo de instrumento?", in Revista de Processo, n. 148, RT, São Paulo, junho de 2007, p. 117).
} 
resolvendo ou não o mérito da causa encerra o ofício de julgar do magistrado em relação a uma pretensão formulada ${ }^{131}$.

Necessário, assim, ignorar a parte inicial do caput do art. 267 a fim de manter a coerência na definição do ato. A consequência prática de tal entendimento é a possibilidade se reconhecer a existência de sentenças terminativas parciais $^{132}$.

Em resumo, segundo esta concepção, tanto a resolução de questões de mérito independentemente do resultado do julgamento, quanto aquelas meramente processuais se acolhidas implicariam a prolação de sentença, que poderia ser parcial ou total. Assim, não seria possível decidir questão de mérito por interlocutória, a qual teria como conteúdo somente a rejeição de matéria preliminar. Eis o reduzido âmbito da decisão interlocutória de acordo com esta concepção: o ato do juiz que rejeita alegação envolvendo pressupostos processuais e condições da ação ${ }^{133}$.

Com o devido respeito, tal posicionamento não pode ser aceito, por razões semelhantes às que permitem concluir ter havido alteração no critério classificatório dos pronunciamentos judiciais. Se o legislador ao reformar o Código fez a clara opção em manter a expressão "extingue-seo processo" ao se referir às sentenças terminativas, não se pode simplesmente ignorar, desconsiderar, texto de lei expresso.

Ao contrário do que se verifica com o julgamento fracionado do mérito, que propicia uma tutela jurisdicional mais efetiva com resultados

\footnotetext{
131 Nas palavras de BRUNO GARCIA REDONDO, "sentença deve ser conceituada como o provimento judicial que, resolvendo ou não o mérito da causa, põe termo, em primeiro grau, ao ofício de julgar do magistrado relativamente a um certo pedido. Ou, em outras palavras, sentença é o ato processual final, de inteligência (lógico) e de vontade (ordem, comando) que põe termo ao ofício de julgar do magistrado em relação a uma pretensão formulada" (cfr. "Sentença parcial de mérito e apelação em autos suplementares" in Revista de Processo, n. 160, RT, São Paulo, junho de 2008, p. 144).

${ }^{132}$ É a conclusão de HEITOR VITOR MENDONÇA SICA: "tudo está a recomendar, portanto, que se ignore a parte inicial do caput do artigo 267, e coerentemente à exegese dos artigos $162, \S 1^{\circ}$ e 269, caput, se reconheça que as sentenças terminativas não necessariamente põem fim ao processo. Em outras palavras, do conjunto normativo decorrente da Lei n. 11.232/2005, é também inevitável reconhecer que haja, no curso do processo, sentenças parciais terminativas" (cfr. "Algumas implicações do novo conceito de sentença, de acordo com a Lei n. 11.232/2005", in CARMONA, Carlos Alberto (coord.). Reflexões sobre a reforma do Código de Processo Civil, Atlas, São Paulo, 2007, p. 197).

${ }^{133}$ Cfr. SICA, Heitor Vitor Mendonça. "Algumas implicações do novo conceito de sentença, de acordo com a Lei n. 11.232/2005", in CARMONA, Carlos Alberto (coord.). Reflexões sobre a reforma do Código de Processo Civil, Atlas, São Paulo, 2007, nota de rodapé n. 35, pp. 197-198.
} 
práticos extremamente positivos às partes, não há qualquer vantagem processual em se considerar, ao arrepio do Código de Processo Civil, as decisões processuais que não extinguem o processo como sentenças terminativas parciais ${ }^{134}$.

Nessa linha, e não deixando se perder de vista a circunstância de que sentença é exatamente aquilo que o legislador o diz ser, não há razão para que se desconsidere o texto legal quando a opção inversa se mostra muito mais vantajosa, visto que mantém intocada técnica já consagrada pela doutrina e jurisprudência e que se revela adequada aos fins a que se propõe ${ }^{135}$.

Destarte, a interpretação mais adequada, tanto em relação ao conceito legal quanto à efetividade que se espera do método estatal de solução de conflitos, é no sentido de que a reforma processual não alterou o conceito de sentença terminativa $^{136}$. $\mathrm{O}$ ato judicial deve extinguir integralmente o processo para que seja qualificado como sentença, caso contrário será classificado como decisão interlocutória $^{137}$, ou seja, se não houver resolução do mérito, a decisão somente será

\footnotetext{
${ }^{134}$ Ora, a decisão processual não faz coisa julgada material, não põe fim à lide, não tem o condão de trazer qualquer alteração ao mundo dos fatos.

135 Dessa forma, a manutenção do conceito de sentença terminativa teria o condão de evitar maiores problemas na esfera recursal: "a redação do art. 267, caput, do CPC - "Extingue-se o processo, sem resolução de mérito" -, permitirá ao intérprete defender que, além do conteúdo de um de seus incisos, a decisão somente poderá ser considerada sentença se extinguir o processo. Como o art. 162, $\S 1^{\circ}$, do CPC prevê que a sentença é o ato do juiz que implica uma das situações previstas pelo art. 267 do CPC, será possivel defender que tais situações somente ocorrerão se respeitado o caput do dispositivo, que exige a extinção do processo. Seria interessante forma de conceituar a sentença terminativa, levando-se em conta tanto o seu conteúdo como seu efeito. Resta claro que nessa hipótese o problema recursal estaria definitivamente resolvido, porque somente seria cabivel o recurso de apelação da decisão que, além de ter como conteúdo uma das matérias previstas pelo art. 267 do CPC, também extingue o processo, em respeito ao caput do dispositivo legal"(cfr. NEVES, Daniel Amorim Assumpção. "O novo conceito de sentença”, in Reforma do CPC: leis 11.187/2005, 11.232/2005, 11.276/2006, 11.276/2006 e 11.280/2006, RT, São Paulo, 2006, p. 86).

${ }^{136}$ Esta é a lição de José RoBerto Dos SANTOS BEDAQUe: “de qualquer modo, o artigo 267 não sofreu alteração substancial. Verificada uma das hipóteses nele descrita, o juiz extinguirá o processo sem resolução do mérito, proferindo sentença" (cfr. "Algumas considerações sobre o cumprimento da sentença condenatória", in Revista do Advogado, n. 85, AASP, São Paulo, maio de 2006, p. 71).

${ }_{137}$ Cfr. ARMELIN, Donaldo. "Notas sobre sentença parcial e arbitragem", in Revista de Mediação e Arbitragem, n. 18, julho a setembro de 2008, p. 282.
} 
sentença se encerrar o processo ${ }^{138}$. Dessa forma, a única hipótese de existência de sentença parcial é o julgamento fracionado do mérito ${ }^{139}$

Em síntese, sempre que o juiz analisar o mérito da causa prolatará sentença, independentemente do encerramento do processo. Contudo, se for proferido provimento de cunho meramente processual, este deve extinguir o processo para que seja classificada como sentença. Pelo conceito legal, portanto, este ato pode ou não extinguir processo, visto que o legislador adotou critério misto em sua definição ${ }^{140}$.

Diante das observações até agora tecidas, é possível fixar outra relevante premissa: a Lei n. 11.232/2005 inseriu expressamente no Código de Processo Civil a possibilidade de análise fracionada do objeto do processo por meio de sentenças parciais de mérito, as quais são definidas exclusivamente com base em seu conteúdo, não sendo possível haver sentença terminativa parcial, visto que esta ainda tem o condão de necessariamente extinguir o processo.

\footnotetext{
${ }^{138}$ Cfr. OLIANI, José Alexandre Manzano. "Cumprimento da sentença interlocutória que condena ao pagamento de soma, de acordo com a Lei 11.232/05", in SANTOS, Ernane Fidélis (coord.); WAMBIER, Luiz Rodrigues (coord.); NERY JR., Nelson (coord.); WAMBIER, Teresa Arruda Alvim (coord.). Execução civil: estudos em homenagem ao professor Humberto Theodoro Júnior, RT, São Paulo, 2007, p. 173-174)

${ }^{139}$ Nesse sentido, afirma José AlEXANDRE MANZANOOlani que "as sentenças interlocutórias, por sua vez, somente podem ter como conteúdo parte do meritum causae. Isto porque, segundo os arts. 162 e 267 do CPC, somente são sentenças processuais os pronunciamentos do juiz que decidam sobre matéria processual e que tenham aptidão para implicar a extinção do processo, enquanto são sentenças de mérito os pronunciamentos que se resolvem total ou parcialmente o mérito da causa, independentemente de terem ou não aptidão para por fim ao processo. À luz dessas considerações tem-se que sentença interlocutória é o pronunciamento judicial que não tem aptidão para extinguir o processo e implica uma das situações previstas no art. 269 do CPC, ou seja, que resolve parcialmente o mérito. As sentenças interlocutórias serão sempre sentenças parciais, uma vez que se todo o objeto litigioso for resolvido pela sentença, ela poderá levar à extinção do processo e, por tal razão, será uma sentença final" (cfr. "Cumprimento da sentença interlocutória que condena ao pagamento de soma, de acordo com a Lei 11.232/05", in SANTOS, Ernane Fidélis (coord.); WAMBIER, Luiz Rodrigues (coord.); NERY JR., Nelson (coord.); WAMBIER, Teresa Arruda Alvim (coord.). Execução civil: estudos em homenagem ao professor Humberto Theodoro Júnior, RT, São Paulo, 2007, p. 176).

${ }^{140}$ JosÉ ROBERTO DOS SANTOS BEDAQUE esclarece a situação da seguinte forma: "agora, portanto, sentença pode ou não pôr termo ao processo. Depende do conteúdo do ato e do sentido da decisão. Melhor explicando. Se não houver resolução de mérito, somente será sentença se extinguir o processo. $O$ acolhimento de uma preliminar ou reconhecimento de ofício da ausência de um requisito de admissibilidade do exame do mérito é ato dessa natureza. Já a rejeição de defesas processuais, como não se verifica a extinção do processo, configura decisão interlocutória. O mesmo ocorre se, embora reconhecida a ausência de requisito processual, o processo não for extinto. A declaração de incompetência, por exemplo, é decisão interlocutória, pois o processo prosseguirá em outro órgão jurisdicional. Se o juízo de valor realizado pelo julgador solucionar, ainda que parcialmente, alguns dos pedidos formulados pelas partes, inclusive em reconvenção ou mediante a técnica das ações dúplices, haverá sentença, embora não se verifique a extinção do processo" (cfr. "Algumas considerações sobre o cumprimento da sentença condenatória", in Revista do Advogado, n. 85, AASP, São Paulo, maio de 2006, pp. 71-72).
} 


\section{JULGAMENTO FRACIONADO DO MÉRITO}

O julgamento parcelado e diferido do mérito é meio de atender ao interesse das partes em ver seus litígios resolvidos com inegável maior rapidez, consubstanciando-se, assim, em importante ferramenta de concretização da garantia constitucional de acesso à "ordem jurídica justa" ${ }^{141}$ (art. 5, XXXV, da Constituição Federal), cuja fundamental importância é de crescente reconhecimento, não só pelos operadores do direito, mas por toda a sociedade ${ }^{142}$.

Ocorre que na vigência do conceito de sentença positivado pelo legislador de 1973, a cisão da análise do mérito - embora prevista em alguns procedimentos especiais, tais como a ação de prestação de contas, a ação demarcatória e a ação de consignação em pagamento - não poderia ser admitida como cláusula geral presente no sistema processual brasileiro. Isto porque, por força dos artigos $162, \S 1^{\circ}$, e 459, ambos do Código de Processo Civil, o juiz somente poderia julgar o mérito por meio de sentença, sendo que este ato, em razão de sua eficácia extintiva da relação jurídica processual, somente poderia ser produzido uma única vez no processo, de modo a obstar o emprego datécnica ora em estudo ${ }^{143}$.

No entanto, segundo RAFAEl CORTE Mello, “ $a$ sentença final que resolve integralmente o mérito da causa, proclamando solução a respeito do

\footnotetext{
${ }^{141}$ Cfr. WATANABE, Kazuo. "Acesso à justiça e sociedade moderna", in GRINOVER, Ada Pellegrini (org.); DINAMARCO, Cândido Rangel (org.); WATANABE, Kazuo (org.). Participação e processo. RT, São Paulo, 1988, pp. 128-135.

${ }^{142}$ Nesse sentido, de acordo com MAURO CAPPELlETTI e BRYANT GARTH, "o direito ao acesso efetivo tem sido progressivamente reconhecido como sendo de importância capital entre os novos direitos individuais e sociais, uma vez que a titularidade de direitos é destituída de sentido, na ausência de mecanismos para a sua efetiva reivindicação. $O$ acesso à justiça pode, portanto, ser encarado como o requisito fundamental - o mais básico dos direitos humanos - de um sistema jurídico moderno $e$ igualitário que pretenda garantir, e não apenas proclamara os direitos de todos. O enfoque sobre o acesso - o modo pelo qual os direitos se tornam efetivos - também caracteriza crescentemente o estudo do moderno processo civil. [...] Os juristas precisam, agora, reconhecer que as técnicas processuais servem a funções sociais. [...] $O$ 'acesso' não é apenas um direito social fundamental, crescentemente reconhecido; ele é, também, necessariamente, o ponto central da moderna processualística" (cfr. "Acesso à justiça", Fabris, Porto Alegre, 2002, pp. 11-13).

${ }^{143}$ Nesse sentido, segundo DANIEl Mitidiero, o conceito de sentença previsto no Código Buzaid, em virtude do critério topológico adotado, não permitia "generalizar essas sentenças parciais, isto, é, tornálas encontráveis no procedimento comum, fato então reclamado, inclusive, pela melhor doutrina" (cfr. "Direito fundamental ao julgamento definitivo da parcela incontroversa: uma proposta de compreensão do art. 273, $\S 6^{\circ}$, CPC, na perspectiva do direito fundamental a um processo sem dilações indevidas (art. $5^{\circ}$, LXXVIII, CF/88)", in Revista de Processo, n. 149, p. 113).
} 
objeto litigioso, é um estandarte idealizado que não se repete em todas as situações submetidas ao crivo do Poder Judiciário". O procedimento ordinário, tal qual idealizado pelo legislador de 1973, não era mais suficiente à satisfação das inúmeras e crescentes necessidades sociais ${ }^{144}$.

Adveio, então, a reforma introduzida pela Lei $\mathrm{n}$. 11.232/05, que trouxe significativas mudanças na estrutura do Direito Processual Civil brasileiro, introduzindo o processo sincrético, no qual cognição e execução se desenvolvem sem solução de continuidade da relação jurídica processual. Assim, foi necessário alterar-se o conceito de sentença, a qual passou a ser caracterizada por seu conteúdo, não mais por sua eficácia extintiva.

Dessa forma, abriram-se as portas à possibilidade de fracionamento da análise do mérito, visto que a sentença deixou de ser ato único no processo, o que possibilitou se cogitar da prolação de mais de uma decisão desta natureza no curso processual, cada qual cuidando de parcela do objeto litigioso. $\mathrm{O}$ sistema passou a comportar a existência de uma decisão de mérito abrangendo apenas parte da pretensão trazida em juízo, sem aptidão para encerrar o processo (ou a fase de cognição) em primeiro grau de jurisdição, mas capaz de conter pronunciamento definitivo acerca de uma parte do objeto litigioso ${ }^{145}$.

Nessa linha, CARlos AlBerto CARMOnA, mostrandosefavorável à adoção do julgamento fracionado do mérito em sede de arbitragem, afirma que antes do advento da Lei n. 11.232/05 a sentença era vista como "ato monolítico, final, conclusivo"; era o ato pelo qual tanto o juiz quanto o árbitro encerravam sua função de aplicar o direito ao caso concreto.

Com a modificação do conceito de sentença, bem como com a transformação da ação de liquidação em fase procedimental, desapareceu o óbice - de ordem pública ou, talvez, de caráter meramente cultural - à prolação de sentenças

\footnotetext{
${ }^{144}$ Cfr. MELLO, Rafael Corte. "Sentenças liminares ou sentenças parciais de mérito?”, in ARMELIN, Donaldo (coord.). "Tutelas de urgência e cautelares", Saraiva, São Paulo, 2010, p. 976.

${ }^{145}$ Cfr. VAZ, Paulo Afonso Brum. "Tutela antecipada fundada na técnica da ausência de controvérsia sobre o pedido ( $\$ 6^{\circ}$ do art. 273 do CPC)", in Revista de Processo, n. 131, p. 137.
} 
parciais, técnica que pode e deve ser utilizada para economizar tempo e dinheiro dos sujeitos processuais parciais ${ }^{146}$.

É de se notar que mesmo após a alteração legislativa, ainda há resistência à admissão da viabilidade do fracionamento do exame do mérito. Argumenta-se que a existência de sentenças parciais causaria indesejada balbúrdia processual, consistente na inadequação de tal ato decisório em relação ao sistema recursal vigente ${ }^{147}$, ponto que será analisado mais detidamente no capítulo subsequente.

De todo modo, é possível afirmar desde logo que o fato de haver o risco de ser desencadeada "aconhecida sequência de recursos que tornam o processo uma diabólica antevisão da eternidade" ${ }^{\text {148 }}$ não é circunstância apta a influenciar de forma decisiva na aceitação ou não da cisão do exame do mérito.

Não há qualquer óbice na essência do Direito Processual à prolação da sentença parcial, sendo certo que - respeitado o entendimento contrário ${ }^{149}$ a aparente incompatibilidade, existenteentre tal provimento judicial e o sistema recursal, deve ser contornada pelos operadores do direito.

Exemplo dessa preocupação com os reflexos de tal instrumento na seara recursal pode ser identificado na posição defendida porNELSON NERY JUNIOR E ROSA MARIA DE ANDRADE NERY. Os processualistasconsideram ser possível, à luz da atual sistemática, a prolação de decisões que possuam conteúdo de mérito, mas que não extingam o processo ou a fase de conhecimento em primeiro grau de jurisdição.

\footnotetext{
${ }^{146}$ Cfr. CARMONA, Carlos Alberto. "Ensaio sobre a sentença arbitral parcial", in Revista de Processo, n. 165, RT, São Paulo, novembro de 2008, pp. 17-18.

${ }^{147}$ Cfr. GONÇALVES FILHO, João Gilberto. "O princípio constitucional da eficiência no processo civil". 2010. Tese (Doutorado em Direito Processual) - Faculdade de Direito, Universidade de São Paulo, São Paulo, 2010. Disponível em: <http://www.teses.usp.br/teses/disponiveis/2/2137/tde-17112011085839/>. Acesso em: 2012-07-03, p. 295.

${ }^{148}$ Cfr. CARMONA, Carlos Alberto. "Ensaio sobre a sentença arbitral parcial", in Revista de Processo, n. 165, RT, São Paulo, novembro de 2008, p. 16.

${ }_{149}$ Cfr. FICHTNER, José Antonio; MONTEIRO, André Luís. "Sentença parcial de mérito na arbitragem”, in Temas de arbitragem: primeira série, Renovar, São Paulo, 2010, pp. 187-188.
} 
Assim, consideram viável a cisão do julgamento do mérito, ainda que não classifiquem tais provimentos como sentenças, preferindo denominá-los de "decisões interlocutórias de mérito". A grande razão para evitar a admissão do fenômeno da sentença parcial reside justamente nas dificuldades recursais daí decorrentes, visto que a remessa dos autos ao Tribunal para julgamento da apelação impediria o prosseguimento do processo em primeiro grau de jurisdição ${ }^{150}$.

Trata-se de posição que, ao menos,confere, em certa medida, maior efetividade ao processo, por admitir a imediata apreciação antecipada de demandas já maduras para julgamento, mas que peca por vincular o conceito de sentença às implicações recursais dele decorrentes.

Contudo, com o devido respeito aos adeptos do entendimento de caráter mais tradicional ${ }^{151}$, os provimentos parciais de mérito não podem ser classificados como decisões interlocutórias, pois não é viável considerar a resolução de uma das demandas propostas em juízo como mera questão incidente (art. $162, \S 2^{\circ}$, do Código de Processo Civil), visto que se trata de decisão sobre o próprio objeto do processo $^{152}$.

$\mathrm{O}$ atual conceito legal de sentença enseja o reconhecimento da possibilidade de sua prolação em relação a parcela das pretensões

\footnotetext{
${ }^{150}$ Cfr. NERY JUNIOR, Nelson; NERY, Rosa Maria Andrade. “Código de Processo Civil Comentado e Legislação Extravagante", $10^{\mathrm{a}}$ ed., RT, São Paulo, 2008, p.851; v. tb. LAZARI, Rafael José Nadim; SOUZA, Gelson Amaro de. "Breves apontamentos sobre a apelação por instrumento", disponível em http://www.abdpc.org.br/abdpc/artigos/Breves\%20Apontamentos\%20sobre\%20a\%20Apela\%C3\%A7\%C $3 \%$ A3o\% 20por\%20Instrumento\%20-

\%20Rafael\%20Jos\%C3\%A9\%20Nadim\%20de\%20LAZARI\%20e\%20Gelson\%20Amaro\%20de\%20SO UZA.pdf, acessado em 28.6.11, p. 16; LUCCA, Rodrigo Ramina de. "Antecipação de tutela da parcela incontroversa do mérito $e$ o conceito de sentença", disponível em http://www.abdpc.org.br/abdpc/artigos/Rodrigo\%20Ramina\%20de\%20Lucca.pdf, acessado em 28.6.11, p. 16.

${ }^{151}$ Humberto THEODORO JÚNIOR é expoente da corrente que entende se tratar de interlocutória, afirmando que "para o ato judicial cognitivo ser tratado como sentença é preciso que todo o pedido ou todos os pedidos da inicial tenham sido resolvidos, positiva ou negativamente. Se o pronunciamento não os abrange em toda extensão, deixando questões para solução no decisório final do processo, não pode ser havido como sentença. Sua natureza, dentro da lógica do sistema, é a de decisão interlocutória, ou seja, a de ato que, no curso do processo, 'resolve questão incidente' (art. 162, § 2')" (cfr. "As novas reformas do Código de Processo Civil", $2^{\text {a }}$ ed., Forense, Rio de Janeiro, 2007, pp. 5-6).

${ }^{152}$ Cfr. REDONDO, Bruno Garcia. "Sentença parcial de mérito e apelação em autos suplementares" in Revista de Processo, n. 160, RT, São Paulo, junho de 2008, pp. 151-152.
} 
deduzidas, sendo que a negativa da existência das sentenças parciais causa insegurança jurídica, por retirar a previsibilidade inerente ao ordenamento jurídico ${ }^{153}$.

Nesse sentido, considerando-se que (i) o art. 162, $\S 1^{\circ}$, conceitua sentença como o ato do juiz que contém alguma das situações previstas nos artigos 267 e 269; (ii) o art. 330 afirma que o juiz conhecerá diretamente do pedido proferindo sentença; e (iii) o art. 459 determina que o juiz deva proferir sentença acolhendo ou rejeitando, no todo ou em parte, o pedido do autor, dúvida não há que as decisões que analisam o mérito de forma fracionada devem ser classificadas como sentenças, conquanto que parciais ${ }^{154}$.

Assim, verifica-se frágil o argumento de que, em razão das dificuldades decorrentes do manejo de recurso de apelação, as sentenças parciais de mérito são, na verdade, decisões interlocutórias. Acompanhando o entendimento de PAUlO AFOnSO DE SOUZA SANT'ANNA, é patente que "não é a recorribilidade que deve definir a natureza da decisão. A decisão deve ser definida pelo seu conteúdo"155.

Ora, é a partir da natureza da decisão que se encontra o recurso cabível, não o contrário; eventuais inconveniências recursais daí decorrentes devem ser equacionadas pelos processualistas, com os olhos sempre voltados a extrair a máxima efetividade do processo.

Cumpre registrar a existência, ainda, de entendimento diverso, o qual, também, respeitosamente, não se perfilha. JoÃo GILBERTO GONÇALVES FILHO afirma que, mesmo antes do advento da Lei n. 11.232/2005, já era possível o fracionamento do julgamento de mérito, por força do princípio da eficiência,

\footnotetext{
${ }^{153}$ Cfr. SCARPARO, Eduardo Kochenborger. "Sentenças parciais? Considerações a partir da reforma do art. 162, $\$ 1^{o}$, do Código de Processo Civil", disponível em http://www.scarparo.adv.br/artigos/sent.pdf, acessado em 6.6.11, p. 23.

${ }^{154}$ Cfr. OLIVEIRA, Bruno Silveira de. "Um novo conceito de sentença?" in Revista de Processo, n. 149, RT, São Paulo, julho de 2007, p. 128; v. tb. MITIDIERO, Daniel. "Direito fundamental ao julgamento definitivo da parcela incontroversa: uma proposta de compreensão do art. $273, \S 6^{\circ}, C P C$, na perspectiva do direito fundamental a um processo sem dilações indevidas (art. $5^{\circ}$, LXXVIII, CF/88)", in Revista de Processo, n. 149, p. 113.

${ }^{155}$ Cfr. SANT'ANNA, Paulo Afonso de Souza. "Sentença parcial", in MEDINA, José Miguel Garcia (coord.); CRUZ, Luana Pedrosa de Figueiredo (coord.); CERQUEIRA, Luiz Otávio Siqueira de (coord.); GOMES JR., Luis Manoel (coord.). Os poderes do juiz e o controle das decisões judiciais: estudos em homenagem à professora Teresa Arruda Alvim Wambier, RT, São Paulo, 2008, p. 460.
} 
implicitamente presente na redação originária da Constituição Federal, e, posteriormente, incluído de forma expressa no caput do art. 37.

Assim, nada teria mudado, visto que "o juiz já tinha e tem flexibilidade para tomar medidas no processo que promovam a sua eficiência em casos como o ora examinado, quando não houver norma legal impeditiva e a medida não malferir outro direito ou garantia fundamental das partes (como o contraditório e a ampla defesa, por exemplo)". Nessa linha, a modificação do conceito de sentença "não trouxe nenhuma nova implicação de ordem prática que já não pudesse ser deduzida do princípio constitucional da eficiência, inerente ao sistema" ${ }^{156}$.

Ocorre que, no caso, à luz da redação original do Código de Processo Civil, o ato do juiz destinado a julgar o mérito da demanda era (e continua sendo) a sentença (art. 459), ao passo que esta, necessariamente, tinha o condão de - ao menos conceitualmente - extinguir o processo (art. 162, $\S 1^{\circ}$ ).

Tal constatação, aliada às características do sistema recursal projetado por Buzaid, fundado na - desejada - perfeita correspondência entre decisões judiciais e recursos cabíveis, leva, invariavelmente, à conclusão de que o julgamento do mérito ocorria sempre ao final do processo, a não ser em hipóteses específicas, previstas em lei de forma taxativa (v.g., ação de prestação de contas, ação de consignação em pagamento, ação demarcatória). Sendo assim, não era possível a admissão de uma cláusulageral de análise fracionada do mérito, fato que é comprovado fartamente pela experiência histórica.

Nesse sentido, emborase concorde com a interpretação das normas processuais à luz da Constituição Federal - como é curial no Estado Democrático de Direito, inserido no cenário pós-positivista, em que a força normativa e a máxima efetividade das normas constitucionais são o toque de caixa da hermenêutica

${ }^{156}$ Cfr. GONÇALVES FILHO, João Gilberto. "O princípio constitucional da eficiência no processo civil". 2010. Tese (Doutorado em Direito Processual) - Faculdade de Direito, Universidade de São Paulo, São Paulo, 2010. Disponível em: <http://www.teses.usp.br/teses/disponiveis/2/2137/tde-17112011085839/>. Acesso em: 2012-07-03, p. 300. 
jurídica $^{157}$-, o fato é que não é possível ignorar as disposições processuais infraconstitucionais para fundamentar todo e qualquer aspecto atinente ao desenvolvimento da relação jurídica processual diretamente nas normas constitucionais. Dúvida não há de que a Carta Magna dá suporte de validade à edição de lei que contemple a possibilidade de se fracionar o mérito da causa, justamente com fulcro no princípio da eficiência.

Entretanto, tal circunstância não autoriza o magistrado, cuja atuação é vinculada ao princípio da legalidade, a agir livremente, desde que encontre - com maior ou menor dificuldade - fundamentação em norma ou interpretação contida na Constituição Federal, sob pena de violação a valores processuais, também de quilate constitucional, tais como a segurança jurídica, o contraditório e a ampla defesa. As regras do jogo processual devem ser claras, evitandose surpresas às partes.

Por tais razões, entende-se que a edição da Lei $n$. 11.232/2005 foi um divisor de águas na cisão do julgamento do objeto processual como cláusula geral presente no sistema processual brasileiro. A partir do novo conceito de sentença estabelecido, a eficácia extintiva - seja do processo, seja de fase processual foi removida do ato, de modo que não há mais óbice a sua prolação no curso do processo, dando azo, assim, à cisão da análise do mérito sempre que esta se mostrar viável $^{158}$.

Pois bem. A sentença parcial de mérito torna possível reduzir o litígio de forma gradual e definitiva ${ }^{159}$, desvinculando pretensões que podem ser imediatamente apreciadas daquelas que demandam maior dilação probatória. É vetor da efetividade processual, alinhado ao princípio da razoabilidade e ao Estado

\footnotetext{
${ }^{157}$ Cfr. LENZA, Pedro. "Direito Constitucional Esquematizado”, 12 ed., Saraiva, São Paulo, 2008, pp. 67-77.

${ }^{158}$ Cfr. CARMONA, Carlos Alberto. "Ensaio sobre a sentença arbitral parcial”, in Revista de Processo, n. 165, RT, São Paulo, novembro de 2008, pp. 17-18.

${ }^{159}$ Nesse sentido, afirma OvíDIO ARAÚJO BAPTISTA DA SILVA que "tanto na sentença definitiva quanto na sentença parcial o juiz pronuncia-se sobre o meritum causae de tal modo que o ponto decidido não mais poderá ser controvertido pelas partes naquela relação processual e nem o julgador poderá sobre ele emitir um julgamento divergente, nas fases posteriores do procedimento" (cfr. "Decisões interlocutórias e sentenças liminares", in Da sentença liminar à nulidade da sentença, Forense, Rio de Janeiro, 2001, p. 21).
} 
Democrático de Direito ${ }^{160}$. Se uma das demandas, ou parcela do pedido decomponível, encontra-se madura,desde logo, para julgamento, nos termos do art. 330, do Código de Processo Civil, é ilógico que sua apreciação somente seja feita no momento em que realizada e encerrada a instrução referente a todo o restante do objeto do processo, pois "uma fruta já madura não precisa esperar o amadurecimento de uma outra, ainda verde, para ser colhida"161. Defender o oposto, seja em razão de ausência de previsão legal expressa - argumento que perdeu significativo poder de persuasão com o advento da Lei n. $11.232 / 2005^{162}$-, seja por temer as consequências no âmbito recursal, "configura excesso de formalismo e revela uma visão defasada com relação ao processo civil moderno"163.

Como bem observou LuIZ GUILHERME MARINONI, não há muito sentido em incentivar o jurisdicionado a cumular demandas, sem a possibilidade de, na hipótese de se mostrar vantajoso, julgá-las em momentos diferentes. Num primeiro momento, prestigia-se a economia processual, mas em seguida sepulta-se a tempestividade da tutela jurisdicional ${ }^{164}$. É certo que a cumulação objetiva de pedidos visa a economizar tempo e dinheiro, sendo de interesse tanto das partes quanto do Judiciário. Nessa linha, não se viabilizar a oportuna descumulação de demandas traria prejuízos ao sistema, visto que, em hipóteses tais, seria mais vantajoso ajuizar duas

\footnotetext{
${ }^{160}$ Cfr. MARTINS, Pedro Batista. "A arbitragem e o mito da sentença parcial”, in CARMONA, Carlos Alberto (coord.); LEMES, Selma Ferreira (coord.); MARTINS, Pedro Batista (coord.). Arbitragem: Estudos em Homenagem ao Prof. Guido Fernando da Silva Soares in memoriam, Atlas, São Paulo, 2007, p. 284.

${ }^{161}$ Cfr. DIDIER JR., Fredie. "Inovações na antecipação dos efeitos da tutela e a resolução parcial do mérito", in Revista de Processo, n. 110, RT, São Paulo, abril-junho de 2003, p. 232.

${ }^{162}$ Cfr. FLACH, Rafael. "A súmula 401 do Superior Tribunal de Justiça e a coisa julgada progressiva", in Revista de Processo, n. 185, RT, São Paulo, julho de 2010, p. 181.

${ }^{163}$ Cfr. SILVA FILHO, Ricardo de Oliveira. "A sentença parcial de mérito e o processo civil moderno", in Revista da AJURIS, n. 108, AJURIS, Porto Alegre, dezembro de 2007, pp. 293-294.

${ }_{164} \mathrm{O}$ professor paranaense continua seu raciocínio, afirmando, corretamente, que: "Se ninguém ousaria dizer que o juiz, diante da evidência de parte do direito postulado, deve simplesmente cruzar os braços e assistir à produção de uma prova que somente tem a ver com a outra parcela do direito, não há como não admitir a tutela antecipatória mediante o julgamento antecipado da parcela do pedido ou de um dos pedidos cumulados" (cfr. MARINONI, Luiz Guilherme. "Tutela antecipatória e julgamento antecipado. Parte incontroversa da demanda", RT, $5^{\mathrm{a}}$ ed., São Paulo, 2002, p. 141).

Nesse sentido é a lição de HeITOR Vitor Mendonça SicA, segundo a qual a cisão do julgamento do mérito ou "desacumulação de demandas" bebe da mesma fonte principiológica que a própria cumulação: a economia e a celeridade processuais: "Afinal, não faria sentido que as demandas fossem cumuladas por medida de economia, para que, a partir de então, jamais pudessem ser separadas, mesmo que isso importasse em amarrar o andamento de uma por conta das demais" (cfr. "Algumas implicações do novo conceito de sentença, de acordo com a Lei n. 11.232/2005", in CARMONA, Carlos Alberto (coord.). Reflexões sobre a reforma do Código de Processo Civil, Atlas, São Paulo, 2007, p. 194).
} 
ações, separadamente, mas com o dobro de gastos e de esforço ${ }^{165}$. Não se trata de solução adequada, pois há instrumentos processuais que podem e devem ser empregados para se conseguir resultado dotado da maior efetividade possível.

Verificada a viabilidade do fracionamento do julgamento do objeto do processo, é dever do magistrado proferir sentença parcial, pois a indevida procrastinação de sua apreciação, para o final desenrolar do processo, atenta contra os princípios da efetividade e da celeridade e contra o senso de justiça. Além disso, a decomponibilidade do objeto litigioso não é novidade no sistema, tendo em vista que, mesmo antes da última reforma, já se admitia a homologação de transação, de reconhecimento jurídico do pedido e de desistência do direito sobre que se funda a ação parciais $^{166}$.

Sendo assim, determinar que a parcela do objeto do processo que se encontre pronta para julgamento imediato deva aguardar a completa instrução da parte ainda não madura e que dependa, v.g., de extensa e custosa perícia, atenta contra o bom senso, contra a lógica do razoável e contra a eficiência que deve permear a Administração Pública.Ora, o julgador deve agir como bom condutor do processo, a fim de produzir os melhores resultados visando à satisfação das necessidades do jurisdicionado, que vê no Judiciário a última chama de sua esperança $^{167}$.

Não existindo qualquer relação de dependência material entre os pedidos, nada justifica o travamento do julgamento de alguns deles, que já se encontram maduros, à espera da resolução de todos ${ }^{168}$. De acordo com BRUNO GARCIA

${ }^{165}$ Cfr. MARTINS, Renato Castro Teixeira. "Apelação por instrumento", in MEDINA, José Miguel Garcia (coord.); CRUZ, Luana Pedrosa de Figueiredo (coord.); CERQUEIRA, Luiz Otávio Siqueira de (coord.); GOMES JR., Luis Manoel (coord.). Os poderes do juiz e o controle das decisões judiciais: estudos em homenagem à professora Teresa Arruda Alvim Wambier, RT, São Paulo, 2008, p. 843.

${ }^{166}$ Cfr. FICHTNER, José Antonio; MONTEIRO, André Luís. "Sentença parcial de mérito na arbitragem", in Temas de arbitragem: primeira série, Renovar, São Paulo, 2010, pp. 158-159.

${ }^{167}$ Cfr. MARTINS, Pedro Batista. "A arbitragem e o mito da sentença parcial", in CARMONA, Carlos Alberto (coord.); LEMES, Selma Ferreira (coord.); MARTINS, Pedro Batista (coord.). Arbitragem: Estudos em Homenagem ao Prof. Guido Fernando da Silva Soares in memoriam, Atlas, São Paulo, 2007, pp. 275-276.

${ }^{168}$ Nas irretocáveis palavras de HeITOR VITOR MENDONÇA SiCA, "não faria sentido que as demandas fossem cumuladas por medida de economia, para que, a partir de então, jamais pudessem ser separadas, mesmo que isso importasse em amarrar o andamento de uma por conta das demais" (cfr. "Algumas 
REDONDO, "não há mais razão prática ou jurídica que justifique a postergação indefinida - até a resolução de todos os pedidos da inicial - da satisfação definitiva de um bem da vida que já possa ser efetivamente reconhecido ao credor, por meio de sentença, antes dos demais" ${ }^{\prime 169}$.

A essa consideração, acrescente-se que o julgamento fracionado do mérito poderá ser efetivado em favor do réu, sujeito processual igualmente destinatário da garantia constitucional à duração razoável do processo. Isto porque, sendo a exceção(defesa) direito processual análogo ao deação, é inadmissível a existência de um "processo civil do autor", visto que o tratamento diferenciado dos sujeitos processuais parciais, pela simples razão de um ter movido a demanda antes do outro, implica grave afronta à isonomia.

É necessário observar a paridade de $\operatorname{armas}^{170}$, de modo que, se verificada, desde logo, a improcedência de parcela da pretensão do autor, deve o juiz rejeitá-la imediatamente, prosseguindo o processo em relação à parte ainda carente de instrução processual.

Dessa forma, observa-se que a prolação de sentença parcial não ofende ao contraditório, nem à isonomia, os quais devem ser assegurados às partes. O magistrado oferecerá aos sujeitos processuais parciais as mesmas oportunidades para se manifestar, bem como os mesmos instrumentos lhes estarão à disposição para fazerem valer seus direitos.

implicações do novo conceito de sentença, de acordo com a Lei n. 11.232/2005", in CARMONA, Carlos Alberto (coord.). Reflexões sobre a reforma do Código de Processo Civil, Atlas, São Paulo, 2007, p. 194). ${ }^{169}$ Cfr. REDONDO, Bruno Garcia. "Sentença parcial de mérito e apelação em autos suplementares" in Revista de Processo, n. 160, RT, São Paulo, junho de 2008, p 151.

${ }^{170}$ Cfr. LUCON, Paulo Henrique dos Santos. "Estabilização da tutela antecipada e julgamento parcial do mérito", disponível

em http://direitoprocessual.org.br/fileManager/Paulo_Lucon__Estabilizao_da_tutela_antecipada_e_julgame nto_parcial_do_mrito.doc, acessado em 10.1.12,pp. 26-27. 
O julgamento parcial não implica parcialidade do juiz, mas somente antecipação do exame de parcela do objeto processual, de acordo com seu livre e motivado convencimento ${ }^{171}$.

De acordo com Paulo HenRiQue dos SAntos Lucon, a consequência imediata do julgamento fracionado do mérito "seria a vantajosa redução dothemadecidendumna sentença. A consequência mediata seria a agilização da atividade dos órgãos jurisdicionais", visto que inexistiria a necessidade de reapreciar o quanto já decidido $^{172}$.

De fato, por meio da sentença parcial, o magistrado irá se manifestar pela última vez acerca do pedido julgado, não podendo modificá-lo posteriormente. Trata-se de decisão definitiva, apta a adquirir a qualidade de coisa julgada material, passível de alteração somente pela via recursal ou por ação rescisória $^{173}$.

Nesse sentido, afirma OvíDIO ARAúJo BAPTISTA DA SILVA que tal qual a sentença definitiva, a "parcial também produz coisa julgada e apenas da primeira se distingue por não encerrar inteiramente o procedimento", de modo que em ambas o magistrado "pronuncia-se sobre o meritum causae de tal modo que o ponto decidido não mais poderá ser controvertido pelas partes naquela relação processual e nem o julgador poderá sobre ele emitir um julgamento divergente nas fases posteriores do procedimento" $" 174$.

Diante da imediata e definitiva solução de parte do litígio, a cisão do julgamento oferece inegável potencial de economia de tempo, fator que é

\footnotetext{
${ }^{171}$ Cfr. WALD, Arnoldo. "A validade da sentença arbitral parcial nas arbitragens submetidas ao regime da CCI”, in Revista de Direito Bancário do Mercado de Capitais e da Arbitragem, n. 17, RT, São Paulo, julho a setembro de 2002, p. 332.

${ }^{172}$ Cfr. LUCON, Paulo Henrique dos Santos. "Estabilização da tutela antecipada e julgamento parcial do mérito", disponível

em http://direitoprocessual.org.br/fileManager/Paulo_Lucon_Estabilizao_da_tutela_antecipada_e_julgame nto_parcial_do_mrito.doc, acessado em 10.1.12, p. 19.

${ }^{173}$ Cfr. AYYUB, Luiz Roberto; PELLEGRINO, Antônio Pedro. “A sentença parcial”, in Revista de Arbitragem e Mediação, n. 22, RT, São Paulo, jul.-set./2009, p. 49.

${ }^{174}$ Cfr. SILVA, Ovídio Araújo Baptista da. "Decisões interlocutórias e sentenças liminares", in Da sentença liminar à nulidade da sentença, Forense, Rio de Janeiro, 2001, pp. 20-21.
} 
elemento determinante à configuração da tutela jurisdicional efetiva ${ }^{175}$. Ora, somente a existência de controvérsia acerca dos fatos justifica o desenvolvimento de instrução probatória, de modo que o pronto julgamento se impõe em face da inexistência daquela.

Destarte, se parcela do litígio encontra-se madura, inexistindo em relação a ela qualquer necessidade de produção de provas, não há razão para procrastinar sua apreciação ${ }^{176}$. Não é admissível se aumente propositadamente o tempo fisiológico do processo, atentando-se contra os princípios da celeridade, da efetividade e da duração razoável do processo, adiando-se o julgamento de capítulos maduros para o final do processo ${ }^{177}$.

Ademais, é possível vislumbrar um provável efeito colateral positivo criado pela decisão parcial de mérito sobre o ânimo das partes, em relação a uma composição amigável, visto que a solução definitiva de parcela da lide lhes confere nova visão sobre as possibilidades, os rumos, as chances de vitória e o custo-benefício do processo ${ }^{178}$.

Há, ainda, na doutrina quem admita o julgamento fracionado do mérito, mas imponha-lhe limites que não lhe são próprios, entendimento com o qual, com a devida vênia, não se pode concordar. Afirma-se que a cisão da análise do mérito, na hipótese de improcedência da demanda, somente deve ocorrer quando a decisão parcial realmente significar economia de "tempo, esforços e dinheiro dos serviços judiciários, ou ainda quando exclui de plano um litisconsorte, evitando à parte excluída o desgaste do processo" ${ }^{\text {179. }}$.

175 Cfr. SANT'ANNA, Paulo Afonso de Souza. "Hipóteses para concessão da tutela antecipatória da parte incontroversa da demanda (art. 273, $\$ 6^{\circ}, C P C$ )", in Revista de Processo, n. 121, p. 118.

${ }_{176}$ Cfr. SANT'ANNA, Paulo Afonso de Souza. "Hipóteses para concessão da tutela antecipatória da parte incontroversa da demanda (art. 273, $\S 6^{\circ}, C P C$ )", in Revista de Processo, n. 121, pp. 124-125.

${ }_{177}$ Cfr. ARAÚJO, José Henrique Mouta. "Coisa julgada progressiva \& resolução parcial do mérito", Juruá, Curitiba, 2008, p. 326; v. tb. SANT'ANNA, Paulo Afonso de Souza. "Hipóteses para concessão da tutela antecipatória da parte incontroversa da demanda (art. 273, $\$ 6^{\circ}$, CPC)", in Revista de Processo, n. 121, p. 127.

${ }^{178}$ Cfr. GIUSTI, Gilberto; MARQUES, Ricardo Dalmaso. "Sentenças arbitrais parciais: uma análise prática", in Revista de Arbitragem, n. 26, RT, São Paulo, jul.-set./2010, p. 53.

${ }^{179}$ Cfr. GONÇALVES FILHO, João Gilberto. "O princípio constitucional da eficiência no processo civil". 2010. Tese (Doutorado em Direito Processual) - Faculdade de Direito, Universidade de São Paulo, São Paulo, 2010. Disponível em: <http://www.teses.usp.br/teses/disponiveis/2/2137/tde-17112011085839/>. Acesso em: 2012-07-03, p. 293. 
De outro lado, caso seja situação de se julgar procedente parcela da demanda, tal decisão somente deverá ser proferida se o ganho de tempo for substancial; a economia de alguns poucos meses na apreciação da parcela do pedido maduro não compensa a perda de segurança jurídica, identificada nos problemas recursais daí decorrentes ${ }^{180}$.

Como reforço argumentativo, em relação a ambas as situações, afirma-se que haveria a indesejável sobrecarga dos Tribunais com diversos recursos parciais sobre a mesma demanda, que seria analisada de forma fracionada, diversas vezes e em momentos inapropriados, sendo que o único ganho real da parte beneficiada com o julgamento parcial seria ter seu pedido analisado em segundo grau de jurisdição com maior rapidez ${ }^{181}$.

Dessa forma, o julgamento fracionado do mérito somente poderá ter vez se substancial parcela da lide comportar julgamento imediato $e$ se a parcela restante ensejar considerável dilação temporal para sua instrução (mais de um ano, pelo menos): fora dessas situações a descumulação de demandas implicaria afronta à economia e à celeridade processuais ${ }^{182}$.

Ora, como dito, não se pode acolher tal posicionamento. A técnica da cisão do julgamento de mérito é aplicada em razão da maior celeridade, economia e efetividade processuais, dela extraíveis. Inicialmente, verifica-se que o resultado de mérito da demanda analisada - procedência, parcial procedência ou improcedência - é irrelevante para determinar a viabilidade do julgamento fracionado. Isto porque tal decisão sempre terá o condão de evitar desgastes e esforços dos sujeitos processuais envolvidos, sendo vetor de economia de tempo por abreviar o período de

\footnotetext{
${ }^{180}$ Cfr. GONÇALVES FILHO, João Gilberto. "O princípio constitucional da eficiência no processo civil". 2010. Tese (Doutorado em Direito Processual) - Faculdade de Direito, Universidade de São Paulo, São Paulo, 2010. Disponível em: <http://www.teses.usp.br/teses/disponiveis/2/2137/tde-17112011085839/>. Acesso em: 2012-07-03, p. 295.

181 Cfr. GONÇALVES FILHO, João Gilberto. "O princípio constitucional da eficiência no processo civil”. 2010. Tese (Doutorado em Direito Processual) - Faculdade de Direito, Universidade de São Paulo, São Paulo, 2010. Disponível em: <http://www.teses.usp.br/teses/disponiveis/2/2137/tde-17112011085839/>. Acesso em: 2012-07-03, pp. 295-297.

182 Cfr. GONÇALVES FILHO, João Gilberto. "O princípio constitucional da eficiência no processo civil”. 2010. Tese (Doutorado em Direito Processual) - Faculdade de Direito, Universidade de São Paulo, São Paulo, 2010. Disponível em: <http://www.teses.usp.br/teses/disponiveis/2/2137/tde-17112011085839/>. Acesso em: 2012-07-03, pp. 296-298 e 303-304.
} 
tramitação em primeiro grau de jurisdição, possibilitando desfecho mais rápido ao ponto passível de imediata definição.

Além disso, não é viável avaliar objetiva, precisa e qualitativamente a espera a que as partes em litígio são submetidas, para, a partir daí, chegar-se a uma quantia de tempo cuja espera seria razoável. Se a matéria está pronta para julgamento, qualquer dilação temporal é indevida e atenta contra a economia processual almejada quando da eventual cumulação de pedidos (lembrando-se de que a cumulação de pedidos é apenas uma das situações que podem ensejar a cisão). Ao se verificar parcela da pretensão madura para julgamento, sua imediata eliminação do objeto do processo é de rigor.

Por fim, no tocante aos problemas recursais existentes, cabe à doutrina e à jurisprudência resolvê-los. Visa-se a alcançar uma técnica processual refinada e alinhada à realidade sociológica em que está inserida. Não se pode negar a busca por aquela em razão de temores relacionados a esta, sob pena de se abdicar à evolução científica.

Assim, a recorribilidade de tais decisões é que tem de ser esclarecida (e o será), e não sua prolação evitada, sendo certo que a carga de trabalho dos Tribunais não sofrerá impacto significativo em razão do fracionamento da análise de demandas que desde o início poderiam ter sido propostas em processos separados - e que fatalmente o seriam, caso o autor pudesse ter razoável grau de previsibilidade acerca da eventual demora no trâmite processual referente à globalidade das pretensões trazidas a juízo.

No mais, a doutrina reconhece a existência de duas situações em que ocorre a cisão do julgamento de mérito: (i) a análise de parcela do objeto litigioso do processo; e (ii) o exameisolado de questões de mérito.

$\mathrm{Na}$ primeira delas, referente ao fracionamento do objeto litigioso do processo, o juiz decide sobre uma parcela deste, prosseguindo adiante o feito para a instrução e julgamento das demais. Configura hipótese admitida pelo sistema processual civil brasileiro, de modo que o juiz tem o dever de excluir desde 
logo do objeto litigioso do processo pretensões que se encontrem aptas a receber pronto julgamento. Trata-se de julgamento parcial, proferido por meio de sentença ${ }^{183}$, conforme acima já afirmado.

Sua viabilidade já foi afirmada, inclusive, por GIUSEPPE ChIOvendA. Após conceituar sentença definitiva como " a que decide sobre a demanda, acolhendo-a ou rejeitando-a", o mestre afirma enfaticamente que se "uma demanda, ou apenas parte de uma demanda, ou apenas a ação relativa à reconvenção, ou vice-versa, está em condições de se decidir, a sentença que a acolhe ou rejeita é, entretanto, definitiva, embora parcial"184. Contra tal decisão deveria ser interposto recurso de apelação imediatamente, visto que "a causa pode, em referência à parte não julgada e independente da julgada, prosseguir sem prejuízo" ${ }^{\text {185. }}$.

O processualista italiano, em seguida,exorta ao leitor que não se deve incidir no erro de considerar como definitiva qualquer decisão que resolva questão de mérito, nem confundir sentença definitiva com sentença final ${ }^{186}$.Isto porque "sentença definitiva, no conceito romano e na lógica processual, é a sentença que se pronuncia sobre a demanda judicial, acolhendo-a ou rejeitando-a, ou declarando não poder decidir sobre ela, ou seja, o ato por meio do qual o juiz satisfaz a prestação que lhe cumpre". Assim, todas as demais decisões, sejam processuais ou de mérito, não são sentenças definitivas, visto que preparatórias a habilitar o juiz para a satisfação da "prestação principal, acolhendo ou rejeitando a demanda".

\footnotetext{
${ }^{183}$ Referindo-se a tal fenômeno, afirma CÂNDIDO RANGEL DINAMARCo que "em todos esses casos o processo prosseguirá pelo pedido que restar, mas a teor da conceituação emergente do art. $162, \S 1^{\circ}$, do Código de Processo Civil, esse julgamento parcial será conceituado como sentença" (cfr. "Instituições de direito processual civil", v. III, $6^{a}$ ed., Malheiros, São Paulo, 2009, p. 700).

${ }^{184}$ Cfr. CHIOVENDA, Giuseppe. "Instituições de direito processual civil", Bookseller, Campinas, 2009 , p. 1.209.

${ }^{185}$ Cfr. CHIOVENDA, Giuseppe. "Instituições de direito processual civil”, Bookseller, Campinas, 2009, p. 1.210 .

${ }^{186}$ Cfr. CHIOVENDA, Giuseppe. "Instituições de direito processual civil", Bookseller, Campinas, 2009, pp. 1.210-1.211.

Cumpre anotar que OvíDIO ARAúJO BAPTISTA DA SILvA identifica a presença da aludida confusão entre sentença final e sentença definitiva na própria doutrina processual italiana. Assevera o processualista gaúcho: "Redenti afirma que algumas sentenças não são definitivas por serem parciais. Ora, o oposto a definitivo não é o parcial, mas o provisório. É um erro gramatical e lógico dizer que uma sentença não é definitiva por ser uma sentença parcial. Se ela encerrar o litígio quanto ao ponto decidido, deverá classificada como definitiva, tanto porque define quanto porque põe termo àquele ponto apreciado pelo julgador" (cfr. "Decisões interlocutórias e sentenças liminares", in Da sentença liminar à nulidade da sentença, Forense, Rio de Janeiro, 2001, p. 20).
} 
Nessa linha, sendo possível que o juiz julgue o objeto litigioso do processo de forma fracionada, "em vários momentos, como na hipótese de cumulação de ações, toda sentença que se pronuncia sobre umas das demandas, ou sobre parte da demanda, é definitiva, conquanto que parcial" $" 187$.

Não se pode, entretanto, cindir a análise dos fundamentos da demanda ou da defesa, antecipando-se a solução de questão de mérito, mas sem a prolação da respectiva sentença - ainda que de sentença parcial se tratasse ${ }^{188}$. Isto porque todas as questões envolvendo o mérito devem ser resolvidas em ato único, integrando, assim, a motivação da sentença, nos termos dos artigos 459 e 458, II, do Código de Processo Civil ${ }^{189}$.

Assim, sob pena de nulidade,por indevido fracionamento do julgamento do mérito, em plena afronta aos referidos dispositivos legais, não pode o magistrado, v.g., no despacho saneador, pronunciar-se sobre a inexistência de um dos fatos extintivos alegados pelo réu (como prescrição, decadência, pagamento ou compensação), nem decidir acerca de um dos fatos constitutivos afirmados pelo autor (como culpa do réu), em ambos os casos determinando o prosseguimento do processo para a instrução das demais questões.

Nessa linha, ou o juiz reputa existente alguma questão de mérito, cuja resolução se mostre suficiente a ensejar o imediato julgamento da pretensão a que ela se refere, proferindo, então, sentença, ou deixa para analisar as questões de mérito conjuntamente no momento de sentenciar ${ }^{190}$.

Nesse ponto, é adequado fazer um paralelo entre o julgamento fracionado do mérito e a teoria dos capítulos de sentença. Não obstante sejam construções inconfundíveis, o breve estudo desta pode ser útil à melhor compreensão daquele.

\footnotetext{
${ }^{187}$ Cfr. CHIOVENDA, Giuseppe. "Instituições de direito processual civil”, Bookseller, Campinas, 2009, p. 1.211 .

${ }^{188} \mathrm{O}$ ponto será aprofundado à frente.

189 Cfr. DINAMARCO, Cândido Rangel. "Instituições de direito processual civil”, v. III, 6 ${ }^{\mathrm{a}}$ ed., Malheiros, São Paulo, 2009, pp. 700-701.

${ }^{190}$ Cfr. DINAMARCO, Cândido Rangel. "Instituições de direito processual civil”, v. III, $6^{\mathrm{a}}$ ed., Malheiros, São Paulo, 2009, pp. 701-702.
} 
CÂNDIDO RAngel Dinamarco conceituaos capítulos de sentença como "unidades autônomas do decisório da sentença" ${ }^{191}$. Em se tratando do meritum causae, cada um dos capítulos representa uma deliberação específica, com pressupostos próprios e independes, sendo que bem poderiam "constituir objeto de julgamentos separados em processos distintos e mediante mais de uma sentença"192.

A natureza complexa ou cindível do objeto do processo irá repercutir, necessariamente, na sentença de mérito, que terá tantos capítulos quantos forem os pedidos formulados ${ }^{193}$.

Dessa forma, apesar da existência de diversas concepções acerca da teoria em tela ${ }^{194}$, o que importa para a formação dos capítulos de sentença não é a existência de pluralidade de fundamentos que embasam a demanda (cumulação de causas de pedir), mas sim a possibilidade de haver diversidade de preceitos concretos a serem pronunciados pelo juiz ao sentenciar ${ }^{195}$.

Apesar de existir, em regra, autonomia entre os capítulos de mérito, pode ser que alguns deles sejam dependentes de outros. Tal ocorre quando se verifica a existência de uma relação de prejudicialidade entre pretensões, sendo que o julgamento de uma (prejudicial) irá determinar os rumos do julgamento da outra (prejudicada).

De todo modo, é de se notar que, embora o julgamento da pretensão prejudicial seja determinante do resultado da pretensão prejudicada, esta poderia ter sido deduzida em demanda autônoma ${ }^{196}$.Podem ser citados como exemplos:

\footnotetext{
${ }^{191}$ Cfr. DINAMARCO, Cândido Rangel. "Capítulos de sentença", $4^{\mathrm{a}}$ ed., Malheiros, São Paulo, 2009, p. 35 .

${ }^{192}$ Cfr. DINAMARCO, Cândido Rangel. "Capítulos de sentença", $4^{\mathrm{a}}$ ed., Malheiros, São Paulo, 2009, p. 34.

${ }^{193}$ Cfr. DINAMARCO, Cândido Rangel. "Capítulos de sentença", $4^{\mathrm{a}}$ ed., Malheiros, São Paulo, 2009, pp. 42-43.

${ }^{194}$ Cfr. DINAMARCO, Cândido Rangel. "Capítulos de sentença”, $4^{\mathrm{a}}$ ed., Malheiros, São Paulo, 2009, pp. 18-30.

${ }^{195}$ Cfr. DINAMARCO, Cândido Rangel. "Capítulos de sentença", 4 ed., Malheiros, São Paulo, 2009, p. 11.

${ }^{196}$ Cfr. DINAMARCO, Cândido Rangel. "Capítulos de sentença", 4 a ed., Malheiros, São Paulo, 2009, p.
} 43. 
os juros são excluídos quando o principal não é devido, mas nada impede que, cobrado só o principal, sejam os juros discutidos em ação posterior; a restituição da coisa não é devida quando o contrato não é rescindido, porém, inexiste óbice a buscar somente a rescisão contratual e, posteriormente, pleitear a restituição da coisa; a indenização não é devida se não houver posse a ser protegida, entretanto, assegurada a posse, não há impedimento ao ajuizamento ulterior de ação visando a obter indenização pelos danos causados ao terreno.

São diversas as situações que ensejam o fenômeno da formação dos capítulos de sentença, de mérito e autônomos, as quais podem ser sistematizadas da seguinte maneira: (i) cúmulo - inicial ou ulterior - de pretensões deduzidas em um só processo; (ii) objeto único, mas passível de decomposição ${ }^{197}$.

Dessa forma, o traço comum a todas as hipóteses de capítulos envolvendo o meritumcausae é que "a sentença é uma só e incindível como ato jurídico integrante do procedimento; também um só e formalmente incindível é o decisório que a integra. Mas substancialmente o decisório comporta divisão, sempre que integrado por mais de uma unidade elementar - residindo cada um dessas em dos preceitos imperativos ali ditados" 198 .

Os capítulos de sentença se verificam quando o petitumdá ensejo a decisum formalmente único, mas com diversos itens, decorrentes da existência de pretensões distintas ou de pretensão que possa ser fragmentada, com a característica de que cada uma delas era passível de ser julgada em processos separados - à exceção dos honorários advocatícios e despesas da sucumbência ${ }^{199}$.

Ora, se a natureza do objeto do processo ensejará sentença integrada por mais de uma unidade elementar, não há óbice que cada uma dessas unidades, na hipótese de vierem a se tornar maduras para julgamento antes das demais,

\footnotetext{
${ }^{197}$ Cfr. DINAMARCO, Cândido Rangel. "Capítulos de sentença”, 4ª ed., Malheiros, São Paulo, 2009, p. 64.

${ }^{198}$ Cfr. DINAMARCO, Cândido Rangel. “Capítulos de sentença”, 4ª ed., Malheiros, São Paulo, 2009, p. 63.

${ }^{199}$ Cfr. DINAMARCO, Cândido Rangel. “Capítulos de sentença”, 4ª ed., Malheiros, São Paulo, 2009, p.
} 63. 
seja cindida em sentenças diferentes ${ }^{200}$. Se for possível o plusde serem julgadas separadamente, em processos diferentes, não há como se negar o minusde julgá-las separadamente no mesmo processo ${ }^{201}$.

Assim, o ponto de encontro entre a cisão do julgamento do mérito e a teoria dos capítulos de sentença é justamente esse: o julgamento fracionado do mérito pode incidir nas situações em que se formariam capítulos de mérito autônomos, ou seja, quando houver objeto processual complexo ou decomponível, sendo igualmente irrelevante a existência de cúmulo de fundamentos ou de causas de pedir $^{202}$.

Dito isto, cumpre analisar os pressupostos necessários à validade do julgamento fracionado do objeto processual.

\subsection{ADMISSIBILIDADE}

À luz do Código de Processo Civil de 1973, a cisão do exame do mérito encontrava dois óbices teóricos à sua ampla efetivação.

O primeiro deles era relacionado à ideia de unicidade da sentença, segundo a qual só poderia haver uma decisão desta natureza ao longo do processo. Tal característica era confirmada pela imposição legal de o pedido do autor ser por ela julgado (art. 459), aliada a sua eficácia extintiva da relação processual,

\footnotetext{
${ }^{200}$ Cfr. Cfr. SICA, Heitor Vitor Mendonça. "Algumas implicações do novo conceito de sentença, de acordo com a Lei n. 11.232/2005", in CARMONA, Carlos Alberto (coord.). Reflexões sobre a reforma do Código de Processo Civil, Atlas, São Paulo, 2007, p. 194.

${ }^{201}$ Nesse sentido, pondera RODRIGO GARCIA DA FONSECA que "do ponto de vista substantivo, portanto, cada capítulo da sentença é como se fosse uma sentença parcial em si, reunidos todos os capítulos num único ato judicial, uma sentença abrangente do todo. Ora, se os capítulos - ou quase-sentenças parciais - podem ser reunidos num mesmo ato, mas são essencialmente separáveis, qual a razão jurídica para que não pudessem ser proferidos em momentos diferentes, se assim fosse do interesse dos litigantes e da melhor administração da Justiça, agilizando a resolução do litígio?" (cfr. "A arbitragem e a reforma processual da execução", in Revista de Arbitragem e Mediação, n. 14, RT, São Paulo, jul-set./2007, p. $37)$.

${ }^{202}$ O cúmulo de causas de pedir não enseja, por si só, a cisão do julgamento do mérito, conforme se verá adiante. Isto porque a causa de pedir refletirá uma questão de mérito a ser resolvida na fundamentação da sentença, de modo que, como já dito, a antecipação do julgamento de uma delas importará em decisão nula, por violação aos artigos 459 e 458, II, do Código de Processo Civil.
} 
decorrente do critério topológico adotado pelo legislador para conceituar o indigitado ato (art. 162, $\S 1^{\circ}$ ). Assim, o objeto do processo era integralmente julgado por uma sentença, que, necessariamente extinguia o processo, sendo una e monolítica, portanto.

Não obstante isso, e, talvez, influenciado pela arraigada concepção romana de que sentença é o ato que julga a demanda, acolhendo-a ou rejeitando-a, o próprio Código previa em alguns procedimentos a existência de mais de um ato sentencial, em que o juiz primeiro definia algum aspecto do objeto processual e, em seguida, determinava o prosseguimento do feito para a análise do restante.

É o que ocorria nos procedimentos especiais envolvendo as ações de prestação de contas, demarcatória e de consignação em pagamento, nas quais o legislador, ao prever mais de uma sentença no mesmo processo, afastou-se do princípio da unicidade da sentença, bem como de seu conceito, previsto no art. $162, \S$ $1^{\circ}$, do Código de Processo Civil.

Assim, como se verá, sea unicidade da sentença, desde a vigência do Código de 1973, não era tida como dogma intocável, com a edição da Lei n. 11.232/2005 e a adoção do critério substancial para a definição do ato sentencial, sem qualquer carga extintiva da relação processual, tal princípio não mais pode ser empregado como impediente à admissão do julgamento fracionado do mérito, no sistema processual civil brasileiro.

O segundo impedimento à aplicação da aludida técnica, consiste no princípio da congruência ou da adstrição à demanda, segundo o qual a atuação do magistrado deve observar limites objetivos e subjetivos. Trata-se da "vinculação do juiz aos limites da demanda, sem lhe ser lícito prover para sujeitos diferentes daqueles que figuram na petição inicial (partes da demanda) ou por motivos diferentes dos que houverem sido regularmente alegados (causa de pedir) ou impondo soluções não pedidas ou referentes a bens da vida que não coincidam com o que na petição inicial estiver indicado (petitum)"203.

${ }^{203}$ Cfr. DINAMARCO, Cândido Rangel. "Instituições de direito processual civil", v. III, $6^{\mathrm{a}}$ ed., Malheiros, São Paulo, 2009, p. 277. 
Nessa linha, a sentença parcial de mérito implicaria possível nulidade consistente em ter o magistrado se pronunciado acerca de menos do que fora pedido pelas partes, configurando-se, assim, situação de denegação de justiça, com plena ofensa ao art. 5, $\mathrm{XXXV}$, da Constituição Federal. Assim, a sentença que analisa apenas parte do objeto litigioso do processo seria citra petita, visto que omissa em relação ao restante do petitum, restando violado o dever do juiz de julgar por inteiro a demanda ${ }^{204}$.

Todavia, propor-se-á uma leitura diferente do princípio da adstrição, de modo a compatibilizá-lo com a prolação de sentenças parciais de mérito, proferidas ao longo do processo. A sentença é chamada de parcial, não porque incompleta, mas sim porque não é total, ou seja, não englobou a totalidade das demandas, sem o consequente encerramento da fase cognitiva do processo sincrético, sendo necessária, portanto, a prolaçãode outra sentença, que definirá acerca do restante do objeto processual ${ }^{205}$.

Destarte, em caso de cisão do julgamento do mérito, a adstrição não deverá ser aferida mediante o confronto da sentença parcial com a integralidade do petitum, mas sim ser analisada em dois momentos: o primeiro, considerando a sentença parcial e a demanda por ela solucionada; o segundo, verificando se a totalidade das demandas propostas foram analisadas de forma integral pelas sentenças parciais, proferidas no curso do processo.

Ademais, conforme se demonstrará, ainda que se considerasse viciado o ato (sentença citra petita), as consequências daí decorrentes não ensejariam sua desconstituição. Isto porque se o único defeito da decisão que analisou parcela da demanda for asuposta omissão, deverá ser determinada tão-somente a prolação de outra sentença que abranja o restante do mérito, mantendo-se hígido o ato decisório parcial, como expressão da máxima pas de nulittèsansgrief e da aplicação do art. 248, do Código de Processo Civil. Dessa forma, o princípio da congruência também não pode ser tido, de forma alguma, como obstáculo à cisão do julgamento de mérito.

${ }^{204}$ Cfr. DINAMARCO, Cândido Rangel. "Instituições de direito processual civil", v. III, $6^{\mathrm{a}}$ ed., Malheiros, São Paulo, 2009, p. 279.

${ }^{205}$ Cfr. SOUZA JUNIOR, Sidney Pereira de. "Sentenças parciais no processo civil - consequências no âmbito recursal", Método, São Paulo, 2009, p. 55. 
Além da inexistência dos referidos óbices teóricos - e da plena compatibilidade da técnica com os demais princípios e valores do direito processual civil, em especial a isonomia, o contraditório e a ampla defesa ${ }^{206}$-, há mandamento constitucional que torna imprescindível a criação pelo legislador e a aplicação pelos operadores do direito de mecanismos que sejam aptos a garantir uma tutela jurisdicional tempestiva, dentro de um processo cuja duração seja razoável.

Destarte, dúvidas não há de que o julgamento fracionado do mérito, admitido de forma ampla pelo sistema processual brasileiro com o advento da Lei n. 11.232/2005, é verdadeira imposição constitucional, decorrente do art. $5^{\circ}$, LXXVIII, da Carta Magna.

\title{
3.1.1. PRINCÍPIO DA UNICIDADE DA SENTENCA
}

\author{
Afirma-se que a ideia de unicidade da sentença foi \\ moldada por GIUSEPPE CHIOVENDA ${ }^{207}$, sendo decorrente do princípio da oralidade ${ }^{208}$, o
}

\footnotetext{
${ }^{206}$ Não há qualquer ofensa à isonomia, pois o julgamento fracionado do mérito poderá ser proferido em favor de qualquer dos sujeitos processuais parciais, bastando, para tanto, que a pretensão esteja madura para julgamento. Nessa linha, observa-se que não há violação ao contraditório e à ampla defesa, pois, a análise do objeto do processo se dará após pleno diálogo entre os sujeitos processuais, de modo a se assegurar a possibilidade de as partes efetivamente influírem na formação da convicção do julgador. Garantir que assim seja é dever do juiz, sendo que a cisão do julgamento do mérito não prejudica qualquer providência nesse sentido.

Quanto ao ponto, afirma José ROBERTO DOS SANTOS BEDAQUEque o magistrado deve "conferir conteúdo substancial, não apenas formal, à igualdade de partes, assumindo a direção material do processo. Igualdade, aliás, que constitui o grande fundamento de todos os princípios constitucionais do processo. Estes existem exatamente para garantir o tratamento isonômico das partes, a fim de que elas possam apresentar-se no processo com paridade de armas, ou seja, com chances equivalentes de afirmar suas razões e demonstrar os fatos necessários ao reconhecimento do direito deduzido. Deve haver entre as partes verdadeiro equilíbrio em todo o curso do processo, com a eliminação de qualquer fator de desigualdade entre elas" (cfr. "Os elementos objetivos da demanda examinados à luz do contraditório", in CRUZ E TUCCI, José Rogério (coord.); BEDAQUE José Roberto dos Santos (coord.). "Causa de pedir e pedido no processo civil (questões polêmicas)”, RT, São Paulo, 2002, pp. 21-22).

Assim, o julgamento fracionado do mérito não é violador dos princípios aludidos. Na verdade, somente ocorrerá de forma válida em função deles, devendo ser propiciado de forma isonômica a ambos os litigantes, por meio da efetiva possibilidade de influir na formação da convicção do julgador acerca da parcela da demanda a ser julgada.

${ }^{207}$ Cfr. MARINONI, Luiz Guilherme. "Técnica processual e tutela dos direitos", RT, São Paulo, 2004, pp. 141-142; v. tb. SANT'ANNA, Paulo Afonso de Souza. "Sentença parcial", in MEDINA, José Miguel Garcia (coord.); CRUZ, Luana Pedrosa de Figueiredo (coord.); CERQUEIRA, Luiz Otávio Siqueira de (coord.); GOMES JR., Luis Manoel (coord.). Os poderes do juiz e o controle das decisões judiciais: estudos em homenagem à professora Teresa Arruda Alvim Wambier, RT, São Paulo, 2008, pp. 453-454.
} 
qual representa, no sistema processual civil brasileiro, um "complexo de ideias", consubstanciado em princípios a ele coligados, como os da concentração, da imediação ou imediatidade, da identidade física do juiz e da irrecorribilidade das interlocutórias $^{209}$.

Nessa linha, um sistema processual regido por tais diretrizes deveria prever a concentração dos atos judiciais em poucas audiências realizadas em curto intervalo de tempo, com a instrução e o julgamento da causa ocorrendo concomitante, possibilitando a prolação da decisão pelo julgador que teve contato direto com as partes e com as provas, em sentença única, sendo que eventuais interlocutórias proferidas seriam irrecorríveis em separado.

No entanto, o princípio da oralidade foi bastante mitigado pelo legislador de 1973, que previu exceções à imediatidade, à identidade física do juiz (art. 132) e à realização de audiência de instrução e julgamento (art. 330) e consagrou a recorribilidade em separado das interlocutórias (art. 522), mantendo-se, contudo, o dogma da unicidade do julgamento de mérito (artigos $162, \S 1^{\circ}$, e 459) ${ }^{210}$.

À luz da redação original do atual Código, afirmava-se que, pelo princípio da unicidade, a sentença não poderia se dispersar ao longo do processo, devendo ser prolatada em momento único, quando acarretaria a extinção da relação jurídica processual. Tal incindibilidade estaria relacionada à impossibilidade de extinção parcial do processo ${ }^{211}$.

\footnotetext{
${ }^{208}$ Cfr. CASSOL, Maria Helena. "Perspectivas atuais da tutela antecipada e a quebra do princípio da unicidade da sentença", in Revista da AJURIS, n. 111, AJURIS, Porto Alegre, setembro de 2008, p. 173.

${ }^{209}$ Cfr. CINTRA, Antônio Carlos de Araújo; GRINOVER, Ada Pallegrini; DINAMARCO, Cândido Rangel. "Teoria Geral do Processo", 20ª ed., Malheiros, São Paulo, 2004, p. 326.

${ }^{210}$ Além disso, afirma LuIz GuILHERMe MARINONIque "o projeto de Chiovenda, ligado à oralidade, esvaziou-se tanto na Itália quanto no Brasil. A falta de estrutura do Poder Judiciário para dar conta das inúmeras causas apresentadas tornou impossível a concentração dos atos processuais, enquanto a demora do processo trouxe grande dificuldade para a implementação da identidade física, o que, por consequência lógica, reduziu a zero o benefício que poderia ser trazido pela imediatidade" (cfr. "Técnica processual e tutela dos direitos", RT, São Paulo, 2004, pp. 141-142).

${ }^{211}$ Cfr. BONÍCIO, Marcelo José Magalhães. "Notas dobre a tutela antecipada 'parcial' na nova reforma do Código de Processo Civil", in Revista dos Tribunais, n. 808, fevereiro de 2003, p. 74; v. tb. FONSECA, Rodrigo Garcia da. "A arbitragem e a reforma processual da execução", in Revista de Arbitragem e Mediação, n. 14, RT, São Paulo, jul-set./2007, p.34.
} 
Sendo assim, de acordo com o princípio "dellaunitá $e$ dellaunicitádelladecisione”, “o mérito não deve ser resolvido pelo juiz em partes, pois seria mais adequado considerar toda a sua extensão quando do julgamento" 212. Impossível seria, portanto, fragmentar a análise do mérito, mesmo que diante de parcela da demanda já apta a receber pronto julgamento ${ }^{213}$.

Apesar do tom de definitividade que emana de tais afirmações, o fato é que tal dogma representa, na verdade, um mito, pois o próprio Código de Processo Civil sempre previu, de forma expressa, situações em que, dentro do mesmo processo e em razão da natureza deste, proferir-se-iam mais de uma sentença $^{214}$, que, sendo sucessivas, na verdade, seriam parciais $^{215}$. Assim, em certa medida, o fracionamento da tutela definitiva não se mostra novidade no sistema processual brasileiro, ainda que até então tenha tido sua incidência limitada a casos específicos $^{216}$.

Vejamos. Na ação de consignação em pagamento, fundada em dúvida sobre quem seja o real credor (art. 335, IV, do Código Civil de 2002), o art. 898, do Código de Processo Civil, autoriza o juiz a proferir sentença julgando extinta a obrigação referente ao pagamento, prosseguindo o processo apenas em relação aos consignados, devendo, ainda, ser prolatada mais uma sentença, definindo-se quem efetivamente receberá a quantia ${ }^{217}$. Há, no caso, induvidoso julgamento parcial de mérito, inclusive com exclusão do consignante da relação jurídica processual, a qual prossegue somente com a participação dos supostos credores e ulterior prolação de mais uma sentença $^{218}$.

\footnotetext{
${ }^{212}$ Cfr. MARINONI, Luiz Guilherme. "Técnica processual e tutela dos direitos", RT, São Paulo, 2004, p. 141.

${ }^{213}$ Cfr. DORIA, Rogéria Dotti. "A tutela antecipada em relação à parte incontroversa da demanda”, RT, São Paulo, 2004, p. 110.

${ }^{214}$ Cfr. REDONDO, Bruno Garcia. "Sentença parcial de mérito e apelação em autos suplementares" in Revista de Processo, n. 160, RT, São Paulo, junho de 2008, p. 148.

${ }^{215} \mathrm{Cfr}$. WALD, Arnoldo. "A validade da sentença arbitral parcial nas arbitragens submetidas ao regime da CCr', in Revista de Direito Bancário do Mercado de Capitais e da Arbitragem, n. 17, RT, São Paulo, julho a setembro de 2002, p. 335 .

${ }^{216}$ Cfr. ARAÚJO, José Henrique Mouta. "Coisa julgada progressiva \& resolução parcial do mérito", Juruá, Curitiba, 2008, p. 340; v.tb. AYOUB, Luiz Roberto; PELLEGRINO, Antônio Pedro. "A sentença parcial", in Revista de Arbitragem e Mediação, n. 22, RT, São Paulo, jul.-set./2009, p. 43.

${ }^{217}$ Cfr. REDONDO, Bruno Garcia. "Sentença parcial de mérito e apelação em autos suplementares" in Revista de Processo, n. 160, RT, São Paulo, junho de 2008, p. 148.

${ }^{218}$ Cfr. ARAÚJO, José Henrique Mouta. "Coisa julgada progressiva \& resolução parcial do mérito", Juruá, Curitiba, 2008, pp. 405-407.
} 
Ainda no tocante à consignatória, o art. $899, \S 1^{\circ}$, do Código, permite ao réu, não obstante tenha apresentado contestação, levantar a quantia ou coisa depositada, liberando-se, assim, parcialmente, o autor. Trata-se de evidentesentença parcial de mérito ${ }^{219}$, que soluciona definitivamente a fração da demanda que carece de ulterior instrução probatória ${ }^{220}$.

Situação semelhante é verificada na ação de prestação de contas, na qual é possível sejam proferidas duas sentenças ${ }^{221}$. A primeira delas envolve a existência do dever de prestar contas, não extingue o processo e dá início à prestação propriamente dita. A segunda determina a existência de eventual saldo devedor, constituindo título executivo judicial a dar ensejo à fase de cumprimento de sentença (art. 915, do Código de Processo Civil) ${ }^{222}$. Nítida, portanto, a cisão do julgamento do mérito e a infração ao dogma da unicidade da sentença ${ }^{223}$.

Ademais, é possível apontar a ação de demarcação de terras como processo que comporta a prolação de mais de uma sentença: a primeira aprecia o pedido de demarcação ou divisão, e, então, ordena o prosseguimento do feito para que se realize o procedimento divisório ou demarcatório (art. 958); a segunda homologa a demarcação realizada (art. 966) ${ }^{224}$.

\footnotetext{
${ }^{219}$ Nesse sentido, afirma ANTONIO CARLOS MARCATOque "o ato judicial contendo a declaração de validade e pertinência do depósito (com a consequente exoneração do autor original tanto da obrigação quanto da relação jurídica processual) não é uma simples decisão - mesmo entendida esta como 'sentença interlocutória de mérito' - mas, sim, verdadeira sentença de mérito, contendo o julgamento do pedido consignatório (art. 269, I) e apelável, portanto" (cfr. "Ação de consignação em pagamento", 6 a ed., Malheiros, São Paulo, 2001, pp. 122-123).

${ }^{220}$ Cfr. ARAÚJO, José Henrique Mouta. "Coisa julgada progressiva \& resolução parcial do mérito", Juruá, Curitiba, 2008, p. 338.

${ }^{221}$ Cfr. DINAMARCO, Cândido Rangel. "Instituições de direito processual civil", v. III, $6^{\mathrm{a}}$ ed., Malheiros, São Paulo, 2009, p. 684; v. tb. WAMBIER, Teresa Arruda Alvim. "Os agravos no CPC brasileiro", 4 ed., RT, São Paulo, 2006, p. 107.

${ }^{222}$ Cfr. REDONDO, Bruno Garcia. "Sentença parcial de mérito e apelação em autos suplementares" in Revista de Processo, n. 160, RT, São Paulo, junho de 2008, p. 148; v. tb. CASSOL, Maria Helena. "Perspectivas atuais da tutela antecipada e a quebra do princípio da unicidade da sentença", in Revista da AJURIS, n. 111, AJURIS, Porto Alegre, setembro de 2008, p. 162; AYOUB, Luiz Roberto; PELLEGRINO, Antônio Pedro. "A sentença parcial", in Revista de Arbitragem e Mediação, n. 22, RT, São Paulo, jul.-set./2009, p. 44-45.

${ }^{223}$ Cfr. ARAÚJO, José Henrique Mouta. "Coisa julgada progressiva \& resolução parcial do mérito", Juruá, Curitiba, 2008, pp. 409-412.

${ }^{224}$ Cfr. REDONDO, Bruno Garcia. "Sentença parcial de mérito e apelação em autos suplementares" in Revista de Processo, n. 160, RT, São Paulo, junho de 2008, p. 148; v. tb. CASSOL, Maria Helena. "Perspectivas atuais da tutela antecipada e a quebra do princípio da unicidade da sentença", in Revista da AJURIS, n. 111, AJURIS, Porto Alegre, setembro de 2008, p. 162; AYOUB, Luiz Roberto; PELLEGRINO, Antônio Pedro. "A sentença parcial", in Revista de Arbitragem e Mediação, n. 22, RT, São Paulo, jul.-set./2009, p. 44-45.
} 
Presentes, ainda, outras hipóteses em que o juiz profere sentença sem extinguir o processo, contrariando, assim, o conceito legal então vigente e o dogma da unicidade da sentença. Pode-se citar o processo de insolvência, na qual esta é declarada por sentença, que não encerra a relação jurídica processual (art. 761, do Código de Processo Civil) ${ }^{225}$. Outro exemplo é o contido no art. 361, que prevê a sentença como ato que julga o incidente de exibição de documento ou coisa, em posse de terceiro, prosseguindo o processo em seus ulteriores termos.

Além das situações previstas no próprio Código, não se pode ignorar que a intensa flexibilização, pelos operadores do direito, de regras processuais que expressamente determinam a indivisibilidade da sentença mostrava-se de comum incidência. Tal se verifica com o art. 315, do Código de Processo Civil, que afirma deverem ser julgadas, na mesma sentença, a ação e a reconvenção.

A prática demonstra que em diversas hipóteses a reconvenção é julgada antes da ação, quando, v.g., dá-se sua rejeição liminar, por razões processuais ou até mesmo de mérito ${ }^{226}$ - nesta última situação se configura, de forma incontestável, hipótese de cisão do julgamento de mérito, excepcionalmente admitida pela doutrina e pela jurisprudência, na forma de decisão interlocutória ${ }^{227}$.

De todo modo, o fato é que o ideal de decisório único não pode ser mantido a todo custo, sacrificando-se a celeridade e comprometendo-se a

\footnotetext{
225 Cfr. DINAMARCO, Cândido Rangel. "Instituições de direito processual civil", v. III, 6 $6^{\mathrm{a}}$ ed., Malheiros, São Paulo, 2009, p. 684; v. tb. WAMBIER, Teresa Arruda Alvim. "Os agravos no CPC brasileiro", 4 ed., RT, São Paulo, 2006, p. 107.

${ }^{226}$ Cfr. ARMELIN, Donaldo. "Notas sobre sentença parcial e arbitragem", in Revista de Mediação e Arbitragem, n. 18, julho a setembro de 2008, p. 282.

${ }^{227}$ Nesse sentido é a opinião de HUMBERTO THEODORO JÚNIOR. Afirma o processualista mineiro que em razão do princípio da unicidade, somente haverá sentença se o ato decisório resolver a integralidade dos pedidos postulados. Se abranger apenas parcela deles, de acordo com a lógica do sistema, tratar-se-á de decisão interlocutória, tendo sido resolvida questão incidente (art. 162, § $2^{\circ}$ ) (cfr. "As novas reformas do Código de Processo Civil", 2a ed., Forense, Rio de Janeiro, 2007, pp. 5-6). Entretanto, não se concorda com tal entendimento, visto que a decisão do juiz que acolhe ou rejeita uma demanda não se limita a resolver questão incidental, visto que dá solução definitiva a parcela do objeto do processo. Nas palavras de GIUSEPPE CHIOVENDA, haveria a divisão em parcelas da "prestação principal" a ser realizada pelo juiz (cfr. "Instituições de direito processual civil", Bookseller, Campinas, 2009, p. 1.211).
} 
obtenção de tutela jurisdicional tempestiva, num processo de duração razoável e sem dilações indevidas $^{228}$.

É preciso ter em mente que a unicidade decorre da oralidade, visto que a decisão deveria ser proferida num procedimento concentrado. Tem como objetivo propiciar um julgamento melhor, visto que o juiz que colheu a prova estaria mais capacitado a realizar a cognição da causa. Se o procedimento não é concentrado e se o objetivo de melhor julgar a causa não é obtido, inexisterazão para que o princípio da unidade da sentença seja observado.

Um bom exemplo da situação acima descrita é a hipótese em que uma das demandas cumuladas torna-se madura para julgamento antes das demais. Parece que impedir sua imediata apreciação, prestigiando a unidade da decisão, representaria situação que - longe de prestigiar - acabaria por, paradoxalmente, vulnerar o próprio princípio da oralidade.

Ora, se o juiz que tem contato com as provas deve julgar a lide (imediatidade e identidade física do juiz), não há sentido em procrastinar o julgamento dessa parcela do objeto litigioso do processo para depois da prática de uma série de atos processuais que com ele não possuem relação alguma (violação ao princípio da concentração).

Diante disso, verifica-se que a cisão do julgamento do mérito é alinhada à identidade física do juiz (propicia o imediato exameda demanda pelo magistrado que tem melhores condições para tanto) e à concentração de atos processuais (evita aguardar a prática de atos inúteis que não se relacionam com a demanda julgada), princípios coligados à oralidade, tal como prevista em nosso ordenamento.

Destarte, cultuar de forma irracional uma regra como fim em si mesmo, desprezando sua origem e seus objetivos, de modo a privilegiar, a ferro e fogo, uma anacrônica suposta unidade do ato sentencial, representa visão comprometida

${ }^{228}$ Cfr. CASSOL, Maria Helena. "Perspectivas atuais da tutela antecipada e a quebra do princípio da unicidade da sentença", in Revista da AJURIS, n. 111, AJURIS, Porto Alegre, setembro de 2008, p. 173. 
unicamente com o processo (instrumento) e não com a prestação jurisdicional devida (fim). Assim, acaba por gerar situação esdrúxula e paradoxal, na qual o princípio decorrente acaba por ferir o princípio do qual decorre.

É de se notar que até mesmo no Direito Italiano o princípio chiovendiano "dellaunità e dellaunicitàdelladecisione" encontra-se amplamente mitigado, por força dos artigos 277 e 278 do Código de Processo Civil italiano. Pelo primeiro dispositivo é possível ao juiz condenar desde logo o réu ao pagamento de uma parcela da quantia devida e já comprovada, submetendo o restante do objeto do processo à instrução probatória ainda necessária. Por força do segundo dispositivo é possível proferir uma sentença condenatória genérica, contendo apenas o na debeatur, de modo que o quantum debeaturserá apurado posteriormente em liquidação.

Nestes casos, o Collegioemite uma provvisionale, condenando o réu a pagar a quantia já provada como devida. Assim, nas obrigações de pagar quantia, o direito processual italiano admite a antecipação da parcela do julgamento que independe de maior dilação probatória ${ }^{229}$.

Nessa linha, é curioso notar - prescindindo-se, ainda que por um instante, até mesmo do instituto da sentença parcial para tal fim-que a própria Lei n. 11.232/2005 prevê expressamente a possibilidade de prolação de ao menos três sentenças no bojo do mesmo processosincrético:a primeira delas, proferidadurante a fase de conhecimento, condena o réu ao pagamento de quantia ilíquida; a segunda, que encerra a fase de liquidação ${ }^{230}$, define o quantum debeatur; a última, que julga a impugnação na fase de cumprimento de sentença, extinguindo-a ${ }^{231}$. Ora, diante disso, indaga-se: que unicidade é essa que comporta três atos sentenciais no mesmo processo?

${ }^{229}$ Cfr. DORIA, Rogéria Dotti. "A tutela antecipada em relação à parte incontroversa da demanda", RT, São Paulo, 2004, pp. 120-121; v. tb. MARINONI, Luiz Guilherme. "Tutela antecipatória de parcela do pedido ou de pedido cumulado", in Revista do TST, n. 66, jan.-mar./2000, p. 79.

${ }^{230}$ Cfr. LUCON, Paulo Henrique dos Santos. "Sentença e liquidação no CPC (Lei n. 11.232/2005)", disponível

em http://novo.direitoprocessual.org.br/fileManager/Paulo_Lucon__Sentena_e_liquidao_no_CPC.doc, acessado em 6.6.11, p. 10.

${ }^{231}$ Cfr. SOUZA JUNIOR, Sidney Pereira de. "Sentenças parciais no processo civil - consequências no âmbito recursal”, Método, São Paulo, 2009, pp. 33-35. 
Ademais - e já retornando o foco sobre as sentenças parciais -, a regra do art. 459, do Código de Processo Civil determina que pela sentença o juiz responderá ao pedido do autor, mas, em momento algum, estabelece que deva haver a unificação em uma só decisão de todas as pretensões deduzidas em juízo.

Nada obsta a prolação de mais de uma sentença, cada qual abarcando parcela do objeto litigioso do processo, com a análise das questões de fato e de direito pertinentes, nos termos do art. 458, II, do Código de Processo Civil. Assim, de acordo com PEDRO BATISTA MARTINS, "tais regras apenas afirmam que o juiz deverá julgar o pedido do autor. Nem mais nem menos", não obstaculizando a cisão do julgamento do mérito ${ }^{232}$.

Se o juiz não apura todas as questões exclusivamente de forma simultânea, nem somente ao final da fase cognitiva, não há sentido que deva proferir apenas uma decisão sobre o mérito, sendo viável que profira sentenças parciais ao longo do processo, conforme as demandas amadureçam ${ }^{233}$.

Não é razoável nem proporcional que se privilegie a unicidade do ato sentencial em detrimento da efetividade processual $^{234}$, em plena afronta à nova redação do art. 162, $\S 1^{\circ}$, do Código de Processo Civil ${ }^{235}$.

Além disso, o mito da unicidade da sentença atenta, ainda, contra o princípio da economia processual, visto que deve ser extraído o máximo de resultado na atuação da regra de direito material com o mínimo possível de atos processuais $^{236}$.

\footnotetext{
${ }^{232}$ Cfr. MARTINS, Pedro Batista. "A arbitragem e o mito da sentença parcial", in CARMONA, Carlos Alberto (coord.); LEMES, Selma Ferreira (coord.); MARTINS, Pedro Batista (coord.). Arbitragem: Estudos em Homenagem ao Prof. Guido Fernando da Silva Soares in memoriam, Atlas, São Paulo, 2007, pp. 273-274.

${ }^{233}$ Cfr. REDONDO, Bruno Garcia. "Sentença parcial de mérito e apelação em autos suplementares" in Revista de Processo, n. 160, RT, São Paulo, junho de 2008, p. 147.

${ }^{234}$ Cfr. SOUZA JUNIOR, Sidney Pereira de. "Sentenças parciais no processo civil - consequências no âmbito recursal", Método, São Paulo, 2009, p. 56.

${ }^{235}$ Cfr. REDONDO, Bruno Garcia. "Sentença parcial de mérito e apelação em autos suplementares" in Revista de Processo, n. 160, RT, São Paulo, junho de 2008, p. 150.

${ }^{236}$ Cfr. MARTINS, Pedro Batista. "A arbitragem e o mito da sentença parcial", in CARMONA, Carlos Alberto (coord.); LEMES, Selma Ferreira (coord.); MARTINS, Pedro Batista (coord.). Arbitragem: Estudos em Homenagem ao Prof. Guido Fernando da Silva Soares in memoriam, Atlas, São Paulo, 2007, p. 276.
} 
À luz de tal contexto e da análise sistemática e teleológica dos artigos 162,§ $1^{\circ}$, e 269, caput, do Código de Processo Civil, é possível concluir que o legislador reformista rompeu de vez com o dogma da unicidade do julgamento de mérito $^{237}$, constatação que encontra fundamento de validade nos incisos XXXV e LXXVIII, do art. $5^{\circ}$, da Constituição Federal ${ }^{238}$.

A modificação do conceito de sentença corrigiu as incongruências existentes, visto que a concepção de sentença então vigente, alinhada à ideia de unicidade, não era compatível com a existência de mais de um ato sentencial no mesmo processo $^{239}$; correção esta que foi realizada por meio da definitiva superação do dogma da incindibilidade da sentença ${ }^{240}$.

Assim, dúvida não há de que, sob o prisma do referido princípio, a cisão do exame do objeto processual tornou-se perfeitamente viável no sistema ${ }^{241}$.

\footnotetext{
${ }^{237}$ Cfr. SICA, Heitor Vitor Mendonça. "Algumas implicações do novo conceito de sentença, de acordo com a Lei n. 11.232/2005", in CARMONA, Carlos Alberto (coord.). Reflexões sobre a reforma do Código de Processo Civil, Atlas, São Paulo, 2007, p. 192.

${ }^{238}$ Cfr. OLIANI, José Alexandre Manzano. "Cumprimento da sentença interlocutória que condena ao pagamento de soma, de acordo com a Lei 11.232/05", in SANTOS, Ernane Fidélis (coord.); WAMBIER, Luiz Rodrigues (coord.); NERY JR., Nelson (coord.); WAMBIER, Teresa Arruda Alvim (coord.). Execução civil: estudos em homenagem ao professor Humberto Theodoro Júnior, RT, São Paulo, 2007, pp. 178-179.

${ }^{39}$ Acerca dessas incongruências, CÂNDIDO RANGEl DinAMARCoexplica que "o parcial retorno ao critério substancial para a conceituação da sentença teve o efeito de superar algumas imperfeições conceituais que vinham desde a vigência do Código de Processo Civil. Em vários dispositivos este cedera inconscientemente ao peso da tradição e referia-se a certas decisões como sentenças, exclusivamente pelo fato de elas se manifestarem sobre o mérito, embora não pusessem fim ao processo, nem ao procedimento, em primeiro grau de jurisdição - sem se lembrar que, segundo seu próprio art. $162, \S 1^{\circ}$, sentença era o ato que punha fim ao processo. [...]Mas agora essa incongruência já não existe, porque a sentença já não é definida como ato que põe fim ao processo" (cfr. "Instituições de direito processual civil', v. III, $6^{\text {a }}$ ed., Malheiros, São Paulo, 2009, p. 684).

${ }^{240}$ Cfr. GRECO, Leonardo. "Primeiros comentários sobre a reforma da execução oriunda da Lei $n$. 11.232/05" in Revista do Advogado, n. 85, AASP, São Paulo, maio de 2006, p. 99; v. tb. ARAÚJO, José Henrique Mouta. "Coisa julgada progressiva \& resolução parcial do mérito", Juruá, Curitiba, 2008, pp. 234-235.

${ }^{241}$ Cfr. SICA, Heitor Vitor Mendonça. "Algumas implicações do novo conceito de sentença, de acordo com a Lei n. 11.232/2005", in CARMONA, Carlos Alberto (coord.). Reflexões sobre a reforma do Código de Processo Civil, Atlas, São Paulo, 2007, p. 193.
} 


\subsubsection{PRINCÍPIO DA CONGRUÊNCIA}

O princípio da congruência impõe ao juiz um duplo dever: "o de pronunciar-se sobretodas as pretensõesformuladas pelas partes e o de pronunciar-sesomente sobre os pedidosefetivamente lamentados" ${ }^{242}$. Funciona, portanto, em dois sentidos: mão e contramão ${ }^{243}$.

A regra encontra fundamentação em dois vetores. $\mathrm{O}$ primeiro deles é identificado no princípio dispositivo ${ }^{244}$, sendo certo que, como regra, no sistema processual civil brasileiro, o magistrado não está autorizado a iniciar processo de ofício, não podendo, consequentemente, acrescentar à sua decisão determinado provimento não pleiteado pelas partes, ainda que se trate de direito indisponível $^{245}$.

O outro fundamento do princípio da correlação é a necessidade de respeito ao contraditório ${ }^{246}$, evitando-se surpresa aos litigantes. É necessário que se lhes conceda um mínimo de previsibilidade acerca dos limites do que será decidido, fornecendo elementos para verificação da possível situação mais favorável, bem como da menos favorável, que podem ser obtidas por meio do processo $^{247}$.

Ademais, verifica-se que o dever do juiz de decidir dentro dos limites das pretensões formuladas, sem conceder mais ou coisa diferente da pleiteada, nem omitir-se em relação a nada do que foi demandado, encontra fundamento

\footnotetext{
${ }^{242}$ Cfr. NORONHA, Carlos Silveira. "Sentença civil: perfil histórico-dogmático", RT, São Paulo, 1995, p. 56; v tb. WAMBIER, Teresa Arruda Alvim. "Nulidades do processo e da sentença", $4^{\mathrm{a}}$ ed., RT, São Paulo, 1997, p. 237.

${ }^{243}$ Segundo BARBOSA MoReira, "ao juiz é proibido exceder o pedido ou julgar fora do pedido, mas não nos esqueçamos de que há o dever, para o juiz, de pronunciar-se sobre todo o pedido; nada além do pedido, mas todo o pedido" (cfr. "Correlação entre o pedido e a sentença", in Revista de Processo, n. 83, p. 210).

${ }^{244}$ Cfr. WAMBIER, Teresa Arruda Alvim. "Nulidades do processo e da sentença", $4^{\mathrm{a}}$ ed., RT, São Paulo, 1997, p. 237.

${ }^{245}$ Cfr. BARBOSA MOREIRA, José Carlos. "Correlação entre o pedido e a sentença", in Revista de Processo, n. 83, pp. 208-209.

${ }^{246}$ Cfr. WAMBIER, Teresa Arruda Alvim. "Nulidades do processo e da sentença", $4^{\mathrm{a}}$ ed., RT, São Paulo, 1997, p. 237.

${ }^{247}$ Cfr. BARBOSA MOREIRA, José Carlos. "Correlação entre o pedido e a sentença", in Revista de Processo, n. 83, p. 209.
} 
legal nos artigos 126, 128 e 460, do Código de Processo Civil ${ }^{248}$. Se o juiz conceder mais do que o pedido, haverá sentença ultra petita; se conceder fora do que foi pedido, a decisão será extra petita; se decidir menos do foi pleiteado, o ato decisório será considerado infra ou citra petita ${ }^{249}$.

O vício da decisão que importa ao presente estudo é aquele verificado na situação em que o juiz decide menos do que foi pedido, proferindo sentença infra petita. Segundo a doutrina e a jurisprudência, trata-se de fenômeno que ocorre com maior frequência na hipótese de uma das demandas cumuladas restar não decidida $^{250}$, ou seja, em situação muito semelhante àquela verificada quando da prolação de sentenças parciais. Situações, como dito, semelhantes, mas que em hipótese alguma podem ser confundidas, conforme se demonstrará.

Nas precisas palavras de CÂNDIDO RANGEL DINAMARCO, a sentença citra petita é "aquela à qual falta algum capítulo de mérito indispensável, o que importa denegação de justiça e desconsideração à própria garantia constitucional do direito de ação, sendo dever do juiz pronunciar-se sobre tudo quanto lhe haja sido pedido" ${ }^{251}$.

No entanto, não é o que ocorre com a sentença parcial, visto que o pedido não analisado por ela será objeto de decisão posterior, não havendo se falar em ausência de capítulo de mérito indispensável, nem em violação à garantia constitucional de acesso ao Judiciário.

O aludido defeito processual - tão grave quanto o do julgamento ultra ou extra petita - é decorrente de uma omissão: a sentença “esquece" de

\footnotetext{
${ }^{248}$ Cfr. DINAMARCO, Cândido Rangel. “Capítulos de sentença”, 4ª ed., Malheiros, São Paulo, 2009, p. 77.

249 Cfr. DINAMARCO, Cândido Rangel. "Instituições de direito processual civil”, v. III, 6 ${ }^{\mathrm{a}}$ ed., Malheiros, São Paulo, 2009, pp. 278-279. É importante consignar que nesta mesma passagem o autor estabelece a fundamental diferença entre conceder menos do que foi pedido (v.g., julgar a demanda parcialmente procedente), situação em que não há qualquer error in procedendo, e decidir menos do que foi pedido (v.g., deixar de julgar uma das pretensões formuladas), fenômeno que dá origem à sentença infra petita.

${ }^{250}$ Cfr. WAMBIER, Teresa Arruda Alvim. "Nulidades do processo e da sentença”, 4a ed., RT, São Paulo, 1997, p. 243.

${ }^{251}$ Cfr. DINAMARCO, Cândido Rangel. “Capítulos de sentença”, 4ª ed., Malheiros, São Paulo, 2009, p. 90 .
} 
julgar uma das pretensões ${ }^{252}$. Contudo, tal omissão somente se verifica quando o juiz deixa sem resposta uma demanda ou parte dela, que podia e devia apreciar na ocasião de sentenciar ${ }^{253}$. Ora, na hipótese de sentença parcial, a parte não examinada não era passível de julgamento naquele momento, somente podendo e devendo ser analisada depois de maior dilação probatória, razão pela qual não se configura situação em que o juiz julga menos do que foi pedido. Não há omissão.

Assim, será infra petitaa sentença que se omite acerca de determinada pretensão que deveria ser enfrentada na exata medida do objeto processual analisado. Dessa forma, se o objetivo da decisão era examinar apenas a parcela da demanda, madura para imediato julgamento, não há se falar em qualquer “esquecimento", visto que o restante dos pedidos será analisado, oportunamente.

O julgamento fracionado do mérito não dá origem a sentença infra petita, pois a decisão parcial de mérito não é destinada a encerrar o litígio integralmente. A sentença parcialnão carrega consigo a vocação ao exame da plenitude do objeto do processo, sendo próprio de sua natureza deixar parcelas do litígio para devida análise em momento posterior,no mesmo processo $^{254}$.

Nesse sentido, por não ser destinada à apreciação da totalidade do mérito, não encerrará a atividade cognitiva do juiz em primeiro grau de jurisdição, não sendo possível se falar na presença do vício citra petita, visto que o restante do objeto processual ainda será objeto de decisão pelo magistrado ${ }^{255}$.

Destarte, o diferimento da decisão no curso do processo não indica omissão judicial, nem descumprimento dos deveres judiciais legalmente

${ }^{252}$ Cfr. BARBOSA MOREIRA, José Carlos. "Correlação entre o pedido e a sentença", in Revista de Processo, n. 83, pp. 210 e 214.

${ }^{253}$ Cfr. CAZETTA JÚNIOR, José Jesus. "Cumulação simples de pedidos e julgamento incompleto do recurso especial: variações em tono de uma questão polêmica", in CRUZ E TUCCI, José Rogério (coord.); BEDAQUE José Roberto dos Santos (coord.). "Causa de pedir e pedido no processo civil (questões polêmicas)", RT, São Paulo, 2002, p. 440.

${ }^{254}$ Nesse sentido, afirma RODRIGO GARCIA DA FONSECA que "a sentença parcial é deliberadamente parcial, e não dá fim ao feito (arbitral ou judicial). A sentença infra petita, ao contrário, encerra o caso, mas ao fazê-lo, deixa em aberto questões que deveriam ter sido decididas. As hipóteses são bem diversas" (cfr. "A arbitragem e a reforma processual da execução", in Revista de Mediação e Arbitragem, n. 14, RT, São Paulo, jul.-set./2007, p. 35).

${ }^{255}$ Cfr. ARMELIN, Donaldo. "Notas sobre sentença parcial e arbitragem", in Revista de Mediação e Arbitragem, n. 18, julho a setembro de 2008, p. 284. 
estabelecidos. Ao revés, em face das circunstâncias e especificidades da causa, tal expediente pode se mostrar indispensável à concretização do processo civil de resultados $^{256}$.

À luz deste contexto, é de se notar que os fenômenos da sentença parcial e da sentença infra petita são bastante diversos, inconfundíveis. Nesta última o órgão jurisdicional comete uma ilegalidade, visto que não enfrenta todos os pedidos formulados que deveriam ser analisados naquele momento, sendo proferida decisão incompleta. Já a primeira, ao contrário, não apresenta necessariamente nenhum vício intrínseco: não há qualquer incompletude, visto que examina pedidos específicos, que se encontram maduros para imediato julgamento, sendo que o restante do objeto litigioso do processo, em razão de em relação a ele ser imprescindível maior dilação probatória, será analisado ulteriormente, completando-se, assim, a prestação jurisdicional ${ }^{257}$.

Destarte, é perfeitamente possível seja infra petitauma sentença parcial. Contudo, tal vício se configurará não pelo fato de o exame realizado pelo magistrado não abranger, naquele momento, a integralidade da causa, mas sim em razão de eventualmente existir o julgamento de menos do que foi pedido, naquela parcelada demanda alcançada pela sentença parcial. Assim, a sentença parcial pode ou não ser infra petita, mas não o será, necessariamente, pelo simples fato de ser parcial.

Em verdade, a constatação é óbvia: tal qual a sentença que abrange a integralidade do litígio, a sentença parcial pode sofrer dos mesmos vícios (extra, ultraouinfra petita), em relação à parcela da demanda analisada; mas o simples fato de ser analisada somente parte do objeto processual não macula de qualquer nulidade a decisão.

Estabelecidas essas premissas, chega-se à conclusão de que o princípio da congruência deve ser considerado à luz do segmento de mérito

\footnotetext{
${ }^{256} \mathrm{Cfr}$. WALD, Arnoldo. "A validade da sentença arbitral parcial nas arbitragens submetidas ao regime da CCr”, in Revista de Direito Bancário do Mercado de Capitais e da Arbitragem, n. 17, RT, São Paulo, julho a setembro de 2002, p. 334 .

${ }^{257}$ Cfr. FICHTNER, José Antonio; MONTEIRO, André Luís. "Sentença parcial de mérito na arbitragem", in Temas de arbitragem: primeira série, Renovar, São Paulo, 2010, pp. 160-161.
} 
analisado pela sentença parcial $^{258}$. Nessa linha, afirma, de forma impecável, DONALDO ARMELINque "o julgamento, na sentença, de uns, apenas, e não de todos [os pedidos], configuraria vício infra petita maculando essa decisão. Mas o seu integral julgamento em mais de uma sentença, se e quando isso for reconhecido como admissível, não importaria na configuração desse vício"259.

Dessa forma, o princípio da correlação entre demanda e sentença deve ser examinado em dois momentos diferentes, na hipótese de prolação de sentença parcial de mérito: primeiro, em relação à decisão parcial e à parcela da demanda efetivamente decidida; segundo, no tocante à decisão final e à parcela da demanda que ainda deveria ser apreciada.

Assim, se a sentença parcial enfrentar a integralidade da fração madura para julgamento, não há se falar na existência de vício citra petita, que somente ocorrerá caso a decisão final não abranja a totalidade do restante do objeto processual.

No entanto, ainda que assim não se considere, ou seja, caso o operador do direito realmente não perceba a diferença entre os fenômenos analisados, asseverando que toda sentença parcial é infra petita, verifica-se que nenhuma utilidade prática poderá ser extraída do reconhecimento do indigitado vício. Vejamos.

A consequência natural da violação ao princípio da congruência é a nulidade da sentença. Entretanto, não há dúvidas acerca da viabilidade de aplicação do art. 248, do Código de Processo Civil às sentenças que contenham tal defeito $^{260}$. De acordo com o referido dispositivo legal, a nulidade de uma parte do ato processual não implicará a nulidade das demais partes, dele independentes.

\footnotetext{
${ }^{258}$ Cfr. ARMELIN, Donaldo. "Notas sobre sentença parcial e arbitragem", in Revista de Mediação e Arbitragem, n. 18, julho a setembro de 2008, p. 284.

${ }^{259}$ Cfr. ARMELIN, Donaldo. "Notas sobre sentença parcial e arbitragem", in Revista de Mediação e Arbitragem, n. 18, julho a setembro de 2008, p. 279.

${ }^{260}$ Cfr. BARBOSA MOREIRA, José Carlos. "Correlação entre o pedido e a sentença", in Revista de Processo, n. 83, p. 214; v. tb. DINAMARCO, Cândido Rangel. "Capítulos de sentença", 4" ed., Malheiros, São Paulo, 2009, p. 90.
} 
Como exemplo, pode ser citado o caso de sentença fruto de julgamento ultra petita. Evita-se a anulação da decisão, limitando-se a decotar o excesso verificado, mantendo-se, no mais, o ato decisório ${ }^{261}$.

Nessa linha de raciocínio, com vistas à instrumentalidade do processo, ainda que se considere a sentença parcial como maculada pelo vício citra petita, cogitar de sua anulação seria um grande desserviço à efetividade processual. Isto porque, se a análise da parcela autônoma da demanda efetivamente julgada pela sentença parcial não for, em si mesma, portadora de qualquer vício, anulá-la seria "inutilizar todo o fruto de uma plantação, pelo motivo de uma parte da roça nada haver produzido" 262 .

O provimento judicial infra petitarepresentaria, na verdade, duas sentenças: uma delas, não eivada do vício, e a outra, inexistente, tanto fática quanto juridicamente ${ }^{263}$. Assim, se uma das partes recorrer da sentença parcial, o pior equívoco que o Tribunal poderia cometer seria anulá-la, visto que estaria contaminando a parte autônoma válida, pela parcela viciada, em plena afronta ao art. 248, do Código de Processo Civil.

Sendo assim, na hipótese de reconhecimento do vício, a solução correta consistiria em manter a decisão parcial de mérito e determinar o retorno do processo ao primeiro grau de jurisdição para que a instrução se finalize e o julgamento se complete ${ }^{264}$.

Destarte, ainda que seja reconhecida a sentença parcial como infra petita, a consequência daí decorrente seria seu aproveitamento, determinando-se o prosseguimento do processo para a decisão da parcela restante do objeto do processo, situação que naturalmente ocorreriase se considerasse inexistente o famigerado defeito. Decidir de forma diferente, anulando-se ato que conseguiu alcançar

${ }^{261}$ Cfr. BARBOSA MOREIRA, José Carlos. "Correlação entre o pedido e a sentença", in Revista de Processo, n. 83, p. 214.

${ }^{262}$ Cfr. DINAMARCO, Cândido Rangel. "Capítulos de sentença", $4^{\mathrm{a}}$ ed., Malheiros, São Paulo, 2009, p. 90.

${ }^{263}$ Cfr. WAMBIER, Teresa Arruda Alvim. "Nulidades do processo e da sentença", $4^{\mathrm{a}}$ ed., RT, São Paulo, 1997, pp. 243-244.

${ }^{264}$ Cfr. DINAMARCO, Cândido Rangel. "Capítulos de sentença", $4^{\mathrm{a}}$ ed., Malheiros, São Paulo, 2009, p. 91. 
os objetivos definidos pelo legislador processual, seria visão comprometida com excessivo formalismo, totalmente alheiaà ideia de efetividade processual e de processo civil de resultados.

Diante disso, a conclusão a que se chega é cristalina: não há qualquer utilidade em considerar a sentença parcial como infra petita, tendo em vista que, de todo modo, o resultado prático será idêntico: a manutenção da decisão parcial de mérito e o prosseguimento do processo para o julgamento do objeto processual restante - desde que, obviamente, a parte já julgada não contenha outro vício que a invalide.

Em resumo, o princípio da congruência não pode ser invocado como óbice à cisão do julgamento de mérito, visto que com ele plenamente compatível.

\subsubsection{DIREITO CONSTITUCIONAL À RAZOÁVEL DURACÃO DO PROCESSO}

Há dois valores que se encontram em contraposição no tocante à duração do processo. O primeiro deles é o da segurança jurídica, pelo qual se exige um lapso temporal mínimo para a tramitação do processo (tempo fisiológico). $\mathrm{O}$ segundo é a celeridade, intimamente ligado à efetividade processual, pelo qual o momento da decisão de mérito não deve ser procrastinado mais do que o estritamente necessário (tempo patológico). A razoável duração do processo encontra-se no equilíbrio entre segurança e celeridade ${ }^{265}$ e é prevista em diversos ordenamentos ao redor do globo.

\footnotetext{
${ }^{265}$ Cfr. CRUZ E TUCCI, José Rogério. “Duração razoável do processo (art. 5”, LXXVIII da Constituição Federal)", in MARTINS, Ives Gandra da Silva (coord.); JOBIM, Eduardo (coord.). O Processo na Constituição, QuartierLatin, São Paulo, 2008, p. 324.

Nesse sentido, afirma FRANCISCO DA FONSECA GAJARDONI que "o grande desafio do processo civil contemporâneo reside no equacionamento desses dois valores: tempo e segurança. A decisão judicial tem que compor o litígio no menor tempo possível. Porém, deve respeitar também as garantias da defesa (dueprocessoflaw), sem as quais não haverá decisão segura. Celeridade não pode ser confundida com precipitação. Segurança não pode ser confundida com eternização" (cfr. "O princípio constitucional da tutela jurisdicional sem dilações indevidas e o julgamento antecipadíssimo da lide", in Revista IOB de Direito Civil e Processual Civil, n. 45, jan-fev./2007, pp. 104-105).
} 
A origem do direito a um processo sem dilações indevidas como direito subjetivo pode ser identificada na Convenção Europeia para Salvaguarda dos Direitos do Homem e das Liberdades Fundamentais, de 4 de novembro de 1950, que em seu art. $6^{\circ}, 1$, dispõe: "Toda pessoa tem direito a que sua causa seja examinada equitativa e publicamente num prazo razoável, por um tribunal independente $e$ imparcial instituído por lei, que decidirá sobre seus direitos e obrigações civis ou sobre o fundamento de qualquer acusação em matéria penal contra ela dirigida"266.

Por força de tal disposição, a Itália, depois de embaraçosa situação vivida junto à Corte Europeia de Direitos Humanos ${ }^{267}$, realizou diversas modificações em seu ordenamento jurídico, visando a assegurar de forma efetiva o direito ao processo sem dilações indevidas, sendo que a maior expressão desse movimento se encontra no art. 111, da Constituição italiana:"La giurisdizione si atua mediante ilgiusto processo regolato dela legge. Ogni processo si svolge nel contraddittorio tra le part, in condizione di paritá, davanti a giudice terzo e imparziale. La legge ne assicura La ragionevoledurata"268.

Ainda no direito europeu, a duração razoável do processo é prevista na Constituição da Espanha, de 1978, em seu art. 24.2: “Todos tem direito ao

\footnotetext{
${ }^{266}$ Cfr. CRUZ E TUCCI, José Rogério. "Duração razoável do processo (art. $5^{\circ}$, LXXVIII da Constituição Federal)", in MARTINS, Ives Gandra da Silva (coord.); JOBIM, Eduardo (coord.). O Processo na Constituição, QuartierLatin, São Paulo, 2008, p. 325.

${ }^{267}$ Com fulcro no direito à razoável duração do processo, previsto na Convenção Europeia, os nacionais italianos passaram a acionar a Corte Europeia em razão da excessiva morosidade da Justiça da Itália. Ocorre que foram tantos os processos movidos por tal motivação que a própria Corte Europeia passou a enfrentar morosidade nos julgamentos. A curiosa situação, segundo PAULO HOFFMAN, causou "grave transtorno político à Itália como membro da Comunidade Europeia, além de natural abalo em sua soberania, principalmente em razão da forte pressão exercida pelos demais países, uma vez que tantos foram os processos de cidadãos italianos perante a Corte Europeia que se causou uma morosidade da própria Corte, a qual se viu às voltas com uma carga excessiva de processos em razão da exagerada duração do processo italiano, que não conseguia mais julgar seus próprios casos em tempo adequado. Diante desse quadro, a Itália viu-se obrigada a, inicialmente, introduzir o justo processo em sua Constituição e, às pressas, aprovar uma lei que prevê a possibilidade de os cidadãos italianos requererem indenização perante as próprias Cortes italianas, porquanto a Convenção Europeia somente admite recursos à Corte Europeia quando esgotada a jurisdição no país-membro ou na hipótese de inexistência de lei que preveja a possibilidade de o jurisdicionado exigir determinado direito perante seu próprio país de origem" (cfr. "O direito à razoável duração do processo e a experiência italiana", in WAMBIER, Teresa Arruda Alvim (coord.), WAMBIER, Luiz Rodrigues (coord.), GOMES JR., Luiz Manoel (coord.), FISCHER, Octavio Campos (coord.), FERREIRA, William Santos (coord.), "Reforma do Judiciário", RT, São Paulo, 2005, p. 574).

${ }^{268}$ Cfr. HOFFMAN, Paulo. "O direito à razoável duração do processo e a experiência italiana", in WAMBIER, Teresa Arruda Alvim (coord.), WAMBIER, Luiz Rodrigues (coord.), GOMES JR., Luiz Manoel (coord.), FISCHER, Octavio Campos (coord.), FERREIRA, William Santos (coord.), "Reforma do Judiciário", RT, São Paulo, 2005, pp. 577-578.
} 
juiz ordinário previamente determinadopor lei, à defesa e à assistência de advogado, a ser informado da acusação contra si deduzida, a um processo público sem dilações indevidas e com todas as garantias..." 269 .

Em Portugal, o Código de Processo Civil determina que o processo não deve conter indevidas procrastinações, conforme se observa de seu art. 21: "A protecção jurídica através dos tribunais implica o direito de obter, em prazo razoável, uma decisão judicial que aprecie, com força de caso julgado, a pretensão regularmente deduzida em juízo, bem como a possibilidade de a fazer executar, 270 .

Por sua vez, no direito estrangeiro do continente americano, a "speedytrialclause" é trazida expressamente na $6^{a}$ Emenda à Constituição dos Estados Unidos da América ${ }^{271}$. No Canadá, o processo sem dilações indevidas é previsto no art. 11, b, da Carta Canadense dos Direitos e Liberdades, que afirma: "Toda pessoa demandada tem o direito de ser julgada dentro de um prazo razoável"272.

No âmbito supranacional interamericano, a Convenção Americana sobre Direitos Humanos, da qual o Brasil é signatário e que vige entre nós com força normativa supralegal, determina em seu art. $8^{\circ}$, 1, que "Toda pessoa tem direito de serouvida com as devidas garantias e dentro de um prazo razoável por um juiz ou tribunal competente, independente e imparcial, instituído por lei anterior, na defesa de qualquer acusação penal contra ele formulada, ou para a determinação de seus direitos e obrigações de ordem civil, trabalhista, fiscal ou de qualquer outra natureza..."273.

\footnotetext{
${ }^{269}$ Cfr. CRUZ E TUCCI, José Rogério. "Duração razoável do processo (art. $5^{\circ}$, LXXVIII da Constituição Federal)", in MARTINS, Ives Gandra da Silva (coord.); JOBIM, Eduardo (coord.). O Processo na Constituição, QuartierLatin, São Paulo, 2008, pp. 330-331.

${ }^{270}$ Cfr. CRUZ E TUCCI, José Rogério. "Duração razoável do processo (art. $5^{\circ}$, LXXVIII da Constituição Federal)", in MARTINS, Ives Gandra da Silva (coord.); JOBIM, Eduardo (coord.). O Processo na Constituição, QuartierLatin, São Paulo, 2008, p. 332.

${ }^{271}$ Cfr. CRUZ E TUCCI, José Rogério. "Duração razoável do processo (art. 5", LXXVIII da Constituição Federal)", in MARTINS, Ives Gandra da Silva (coord.); JOBIM, Eduardo (coord.). O Processo na Constituição, QuartierLatin, São Paulo, 2008, p. 334.

${ }^{272}$ Cfr. CRUZ E TUCCI, José Rogério. "Duração razoável do processo (art. $5^{\circ}$, LXXVIII da Constituição Federal)", in MARTINS, Ives Gandra da Silva (coord.); JOBIM, Eduardo (coord.). O Processo na Constituição, QuartierLatin, São Paulo, 2008, p. 334.

${ }^{273}$ Cfr. CRUZ E TUCCI, José Rogério. "Duração razoável do processo (art. $5^{\circ}$, LXXVIII da Constituição Federal)", in MARTINS, Ives Gandra da Silva (coord.); JOBIM, Eduardo (coord.). O Processo na Constituição, QuartierLatin, São Paulo, 2008, p. 335-336.
} 
Finalmente, a Constituição Federal de 1988, já continha sinais claros do reconhecimento pelo Poder Constituinte Originário da necessidade de uma Justiça rápida. Tanto é que no art. 93, II, “c", a presteza foi elencada entre os requisitos para promoção dos magistrados por merecimento. Uma década depois, em 1998, com a Emenda Constitucional n. 19, acrescentou-se a eficiência como princípio fundamental da Administração Pública, previsto no caput do art. 37. Por fim, o Constituinte Derivado editou a Emenda Constitucional n. 45/04, que trouxe a Reforma do Judiciárioe implantou uma série de modificações destinadas a imprimir maior celeridade ao processo $^{274}$.

Segundo José ReNATO NALINI, por meio da EC n. 45/04, o Constituinte derivado "pretendeu motivar o juiz brasileiro. Incluiu a produtividade como critério aferidor de merecimento [93, II, “c”]. Suspendeu as paralisações coletivas, com a interrupção temporária dos serviços judiciais [art. 93, XII]. Ordenou a distribuição imediata de todos os feitos [art. 93, XV]. Não satisfeito, incluiu um inciso a mais na longa enunciação do art. $5^{\circ}$ da Constituição da República, e criou um novo direito fundamental: 'a todos, no âmbito judicial e administrativo, são assegurados a razoável duração do processo e os meios que garantam a celeridade de sua tramitação' [art. 5', LXXVIII]"275.

Sendo assim, a Constituição Federal prevê o direito fundamental de acesso à ordem jurídica justa e efetiva (art. $5^{\circ}, \mathrm{XXXV}$ ), devendo a proteção judicial ser conferida às partes em tempo razoável (art. $5^{\circ}$, LXXVIII, introduzido pela Emenda Constitucional n. 45/04). Dessa forma, o Estado deve organizar seu método de trabalho de forma a dele eliminar toda e qualquer forma de dilação indevida ${ }^{276}$. Não basta garantir o acesso ao Judiciário, é necessário que se

\footnotetext{
274 Cfr. NALINI, José Renato. "Ética da Magistratura”, RT, São Paulo, 2009, p. 34.

${ }^{275}$ Cfr. NALINI, José Renato. "Ética da Magistratura”, RT, São Paulo, 2009, p. 120.

${ }^{276}$ Cfr. MITIDIERO, Daniel. "Direito fundamental ao julgamento definitivo da parcela incontroversa: uma proposta de compreensão do art. $273, \S 6^{\circ}, C P C$, na perspectiva do direito fundamental a um processo sem dilações indevidas (art. 5, LXXVIII, CF/88)", in Revista de Processo, n. 149, pp. 110-111.
} 
assegure a todos a adequada tutela jurisdicional ${ }^{277}$, por meio do devido processo legal efetivo $^{278}$.

Destarte, não há dúvidas de que o direito ao processo sem dilações indevidas integra a ideia de devido processo constitucional, sendo direito fundamental dotado de aplicabilidadeimediata, por força do art. $5^{\circ}, \S 1^{\text {o }}$, da Constituição $^{279}$.

Uma das muitas funções dos direitos fundamentais é servir de baliza à interpretação da legislação infraconstitucional, ou seja, o exercício interpretativo das regras jurídicas deve ser realizado conforme aos direitos fundamentais $^{280}$. Nessa linha, existindo mais de uma interpretação possível a um instituto processual, deve ser prestigiada aquela que garanta com maior intensidade a efetividade dos direitos fundamentais ${ }^{281}$.

Nesse contexto, ganham expressivo relevo disposições contidas no ordenamento jurídico infraconstitucional,vocacionadas a dialogar com o anseio da sociedade por uma justiça mais célere e efetiva.

O próprio Código de Processo Civil de 1973 trouxe regras de aceleração do procedimento, como o julgamento antecipado da lide (art. 330).

O Estatuto da Magistratura impôs aos magistrados os deveres de "não exceder injustificadamente os prazos para sentenciar ou despachar"

\footnotetext{
${ }^{277}$ Cfr. CRUZ E TUCCI, José Rogério. “Duração razoável do processo (art. 5’, LXXVIII da Constituição Federal)", in MARTINS, Ives Gandra da Silva (coord.); JOBIM, Eduardo (coord.). O Processo na Constituição, QuartierLatin, São Paulo, 2008, pp. 324-325.

${ }^{278}$ Cfr. CRUZ E TUCCI, José Rogério. "Duração razoável do processo (art. 5", LXXVIII da Constituição Federal)", in MARTINS, Ives Gandra da Silva (coord.); JOBIM, Eduardo (coord.). O Processo na Constituição, QuartierLatin, São Paulo, 2008, pp. 341-342.

${ }^{279}$ Cfr. CRUZ E TUCCI, José Rogério. "Duração razoável do processo (art. 5", LXXVIII da Constituição Federal)", in MARTINS, Ives Gandra da Silva (coord.); JOBIM, Eduardo (coord.). O Processo na Constituição, QuartierLatin, São Paulo, 2008, p. 342.

${ }^{280}$ Cfr. MITIDIERO, Daniel. "Direito fundamental ao julgamento definitivo da parcela incontroversa: uma proposta de compreensão do art. $273, \S 6^{\circ}, C P C$, na perspectiva do direito fundamental a um processo sem dilações indevidas (art. 5, LXXVIII, CF/88)", in Revista de Processo, n. 149, p. 110.

${ }^{281}$ Cfr. MITIDIERO, Daniel. "Direito fundamental ao julgamento definitivo da parcela incontroversa: uma proposta de compreensão do art. $273, \S 6^{\circ}, C P C$, na perspectiva do direito fundamental a um processo sem dilações indevidas (art. 5, LXXVIII, CF/88)", in Revista de Processo, n. 149, p. 111.
} 
(art. 35, II) e "determinar as providências necessárias para que os atos processuais se realizem nos prazos legais" (art. 35, III).

Mais recentemente, o Código de Ética da Magistratura trouxe a celeridade como verdadeiro comando ético direcionado a todos os juízes, afirmando que lhes cabe "velar para que os atos processuais se celebrem com a máxima pontualidade e para que os processos a seu cargo sejam solucionados em um prazo razoável"'(art. 20) $)^{282}$.

É dever constitucional, legal e ético do magistrado pautar seu comportamento pela celeridade, conduzindo o processo de maneira que sua duração seja razoável, sem dilações indevidas ${ }^{283}$.

Assim, ao CPC alterado pela Lei n. 11.232/2005 deve ser conferida interpretação condizente com a necessidade de prestação jurisdicional célere, em tempo razoável, a fim de dele extrair a máxima efetividade processual ${ }^{284}$.

Mas qual seria o conteúdo de tais expressões? É patente que "duração razoável" e "sem dilações indevidas" são conceitos abertos, de definição complexa ${ }^{285}$. Não obstante isso, a melhor doutrinase inclina a preenchê-los com a ideia de "atrasos ou delongas que se produzem no processo por inobservância dos prazos

\footnotetext{
${ }^{282}$ Cfr. NALINI, José Renato. "Ética da Magistratura”, RT, São Paulo, 2009, p. 120.

${ }^{283}$ Acerca do ponto, vale a integral transcrição da clássica e sempre atual lição de RUI BARBOSA: "Mas a justiça atrasada não é justiça, senão injustiça qualificada e manifesta. Porque a dilação ilegal nas mãos do julgador contraria o direito escrito das partes, e, assim, as lesa no patrimônio, honra e liberdade. Os juízes tardinheiros são culpados, que a lassidão comum vai tolerando. Mas sua culpa tresdobra com a terrível agravante de que o lesado não tem meio de reagir contra o delinqüente poderoso, em cujas mãos jaz a sorte do litígio pendente. Não sejais, pois, desses magistrados, nas mãos de quem os autos penam como as almas do purgatório, ou arrastam sonos esquecidos com as preguiças do mato" (cfr. "Oração aos moços", 6 a ed., Edições Casa de Rui Barbosa, Rio de Janeiro, 2003, p. 40).

${ }^{284}$ Nessa linha, são precisas as afirmações de LuIZ RoBERTO AyOUB e ANTÔNIO PEDRO PELLEGRINO: "Saliente-se, por oportuno, que, trazida pela Lei 11.232/2005, a nova conceituação de sentença é consectário lógico da efetividade da prestação jurisdicional. Isto porque, à vista, por exemplo, de cumulação objetivo simples de pedidos, o juiz de direito, perante um pedido maduro, lançará mão da sentença parcial, seguindo o processo o seu curso no tocante aos demais pedidos (estes pedidos, à guisa de exemplo, exigem dilação probatória). Ao assim proceder, está o magistrado arrimado na Constituição da República (art. 5o, LXXVIII, CF/1988)" (cfr. "A sentença parcial", in Revista de Arbitragem e Mediação, n. 22, RT, São Paulo, jul.-set./2009, p. 50).

${ }^{285} \mathrm{Cfr}$. OLIANI, José Alexandre Manzano. "Cumprimento da sentença interlocutória que condena ao pagamento de soma, de acordo com a Lei 11.232/05", in SANTOS, Ernane Fidélis (coord.); WAMBIER, Luiz Rodrigues (coord.); NERY JR., Nelson (coord.); WAMBIER, Teresa Arruda Alvim (coord.). Execução civil: estudos em homenagem ao professor Humberto Theodoro Júnior, RT, São Paulo, 2007, p. 179.
} 
estabelecidos, por injustificados prolongamentos das etapas mortas que separam a realização de um ato processual de outro, sem subordinação a um lapso temporal previamente fixado e, sempre, sem que aludidas dilações dependam da vontade das partes ou de seus mandatários"286.

De todo modo, não é possível fixar de forma apriorística um conteúdo específico para a regra de duração razoável do processo, não sendo adequado afirmar que as dilações indevidas decorrem do simples desrespeito aos prazos processuais fixados pelo legislador. Apesar das dificuldades inerentes à matéria, a Corte Europeia dos Direitos do Homem adotou três critérios capazes de servir de norte na identificação da razoabilidade na duração do processo no caso concreto. Devem ser levados em conta: (a) a complexidade da causa; (b) o comportamento das partes e de seus procuradores; (c) a atuação do órgão jurisdicional ${ }^{287}$.

Nesse momento, revela-se apropriado examinar se e como o julgamento fracionado do mérito se relaciona com os critérios acima indicados para identificação de um processo sem dilações indevidas. Se a complexidade de uma das demandas cumuladas ou de parcela do pedido decomponível já se encontra elucidada pelos elementos de cognição presentes no processo, adiar sua apreciação implicará dilação processual indevida (primeiro critério). Igualmente, se as partes, por meio de seu comportamento, possibilitam o imediato julgamento de mérito de parcela do objeto processual (v.g., reconhecimento jurídico de um dos pedidos cumulados), não há dúvidas de que postergar a apreciação judicial implicará aumento patológico na duração do processo (segundo critério). Assim, se o magistrado em tais situações deixa de cindir o julgamento do mérito, adiando-o indevidamente, estará atuando de forma incompatível com a razoável duração que se espera do processo (terceiro critério). Portanto, o julgamento fracionado do mérito é ferramenta que assegura um processo efetivo e célere.

\footnotetext{
${ }^{286}$ Cfr. CRUZ E TUCCI, José Rogério. “Tempo e processo”, RT, São Paulo, 1997, p. 67.

${ }^{287}$ Cfr. CRUZ E TUCCI, José Rogério. "Duração razoável do processo (art. $5^{\circ}$, LXXVIII da Constituição Federal)", in MARTINS, Ives Gandra da Silva (coord.); JOBIM, Eduardo (coord.). O Processo na Constituição, QuartierLatin, São Paulo, 2008, pp. 326-327; v. tb. HOFFMAN, Paulo. "O direito à razoável duração do processo e a experiência italiana", in WAMBIER, Teresa Arruda Alvim (coord.), WAMBIER, Luiz Rodrigues (coord.), GOMES JR., Luiz Manoel (coord.), FISCHER, Octavio Campos (coord.), FERREIRA, William Santos (coord.), "Reforma do Judiciário", RT, São Paulo, 2005, p. 586.
} 
Além desses critérios, é possível encontrar na doutrina o entendimento de que a duração razoável do processo pode ser aferida por meio de um juízo de proporcionalidade, passando pela análise de três categorias: adequação, necessidade e proporcionalidade em sentido estrito.

De acordo com tal posição, é preciso, inicialmente, verificar se o tempo eventualmente maior na tramitação do processo é adequado aos fins a que se quer por meio dele alcançar (v.g., uma causa complexa, que demande a realização de custosa e trabalhosa perícia, tende a ter um período de tramitação maior que uma causa versando questão exclusivamente jurídica). Em caso de resposta positiva, passa-se ao exame do segundo elemento, analisando-se se o tempo efetivamente consumido no processo foi estritamente o necessário à prática dos atos tendentes a seu desfecho ou se a marcha processual poderia ter sido realizada de forma mais célere (v.g., independentemente da adequação do maior ou menor prazo de trâmite, eventual dilação decorrente do tempo que o processo fica guardado no escaninho do cartório, em razão de excesso de serviço, não pode ser considerado como necessárioà solução do litígio).Por fim, deve ser constatado se as vantagens alcançadas pelas partes por meio do processo superam as desvantagens decorrentes da demora em seu trâmite. Se a resposta aos três critérios for afirmativa, o processo não terá sofrido dilações indevidas, tendo sido observado o direito constitucional a sua duração razoável ${ }^{288}$.

Nesse sentido, se há demandas cumuladas, sendo que uma delas encontra-se madura para julgamento, enquanto a outra não prescinde da produção de complexa prova pericial, é de rigor concluir que adiar o julgamento da primeira por circunstâncias atribuíveis exclusivamente à segunda, importa, em relação a essa pretensão,numa patenteinadequação na duração do processo, visto que o tempo gasto se mostraria flagrantemente maior do que o apropriado a alcançar o fim almejado (julgamento de mérito da pretensão madura).

Dessa forma, a resposta negativa à primeira das categorias que compõem o juízo de proporcionalidade para aferição da duração razoável do

\footnotetext{
${ }^{288}$ Cfr. GUERREIRO, Mario Augusto Figueiredo de Lacerda. "Critérios para a densificação do conceito de 'prazo razoável' no processo civil", in Revista de Direito do Tribunal de Justiça do Estado do Rio de Janeiro, n. 70, jan-mar/2007, p. 53.
} 
processo já é suficiente à constatação de que inadmitir a cisão do julgamento do mérito implica visão comprometida com um processo civil marcado por dilações temporais indevidas.

A prática de qualquer ato processual posterior ao amadurecimento da demanda para julgamento representa ofensa a este direito fundamental a um processo sem dilações indevidas ${ }^{289}$. Ora, se no curso do processo a controvérsia existente se limitar a matéria de direito, cumpre ao juiz julgá-la desde logo, analisando sem mais delongas o pedido ${ }^{290}$. Não há razão para que tal solução não seja igualmente aplicada na hipótese de apenas parcela da demanda encontrar-se em tal situação, proferindo o juiz, em relação a ela, imediatamente sua decisão.

A decisão sobre o mérito somente poderá ser postergada caso o themadecidendum reclamar dilação probatória, sendo certo que cada vez mais fracos e ilusórios serão os efeitos da sentença quanto mais tardio for o julgamento ${ }^{291}$.

Tendo o magistrado firmado seu entendimento e encerrado a atividade cognitiva em relação a parcela do objeto processual, nada legitima o retardamento de seu julgamento, apenas para sincronizá-lo com o exame do restante da demanda - configurando-se, entre o amadurecimento desta fração e o julgamento final, lapso temporal totalmente estéril. De acordo com BRUNO SILVEIRA DE OLIVEIRA, “perseguir esse 'sincronismo' entre os julgamentos dos vários capítulos da demanda é - além de uma dilação inteiramente inútil - prática perversa para com a parte que tem razão, 292 .

No entanto, há na doutrina quem encare com acentuado ceticismo a possibilidade de cumprimento do direito fundamental inserido pela Emenda Constitucional n. 45/04, afirmando que melhor seria ter sido evitada a desvalorização do texto constitucional, postergando-se a inclusão de tal promessa quando houvesse

${ }^{289}$ Cfr. MITIDIERO, Daniel. "Direito fundamental ao julgamento definitivo da parcela incontroversa: uma proposta de compreensão do art. $273, \S 6^{\circ}$, CPC, na perspectiva do direito fundamental a um processo sem dilações indevidas (art. $5^{\circ}$, LXXVIII, CF/88)”, in Revista de Processo, n. 149, p. 111.

${ }^{290}$ Cfr. ZAVASCKI, Teori Albino. "Antecipação da tutela em face de pedido incontroverso", in Revista Jurídica, n. 301, novembro de 2002, pp. 30-31.

${ }^{291}$ Cfr. CRUZ E TUCCI, José Rogério. "Tempo e processo", RT, São Paulo, 1997, p. 48 e 63-66.

${ }^{292}$ Cfr. "Um novo conceito de sentença?" in Revista de Processo, n. 149, RT, São Paulo, julho de 2007, p. 128. 
mínimas condições fáticas a fornecer esperança de que o tempo de duração do processo pudesse ser controlado ${ }^{293}$.

Ocorre que o direito a um processo sem dilações indevidas tem, além do aspecto de direito subjetivo concedido aos litigantes, um viés nitidamente programático, dirigido ao Estado, na dimensão de todas as suas funções. O Poder Legislativo tem o dever de estruturar procedimentos que possibilitem a concessão de tutela jurisdicional em sintonia com uma racional distribuição do tempo no processo. $\mathrm{O}$ Poder Executivo deve oferecer as condições materiais de estruturação para o adequado funcionamento da função jurisdicional e oferecer o apoio integral para o cumprimento fiel das decisões dela decorrentes. O Poder Judiciário, por seu turno, tem o dever de utilizar da forma adequada os instrumentos processuais, materiais e humanos colocados à sua disposição ${ }^{294}$. A cisão do julgamento do mérito é, sem sombra de dúvida, um desses mecanismos.

Os reflexos do tempo no processo são relevantíssimos. A intempestividade da tutela jurisdicional tende a beneficiar a parte que não tem razão, mantendo-a por mais tempo do que o necessário com o bem da vida que indevidamente possui.

Além disso, tem potencial de acentuar as desigualdades sociais, já que um processo lento pode favorecer a parte mais rica, que, por ter condições de aguardar indefinidamente pelo desfecho de um processo moroso, tem a possibilidade de usar a lentidão do meio estatal de solução de conflitos como barganha para chegar a acordo mais vantajoso para si, oferecendo à parte economicamente hipossuficiente, de forma imediata, pequena parcela do que é realmente devido.

Some-se a isso a circunstância de que quanto mais tempo se passa entre a ocorrência dos fatos originadores do litígio e seu julgamento, menores

\footnotetext{
${ }^{293}$ Cfr. CARMONA, Carlos Alberto. "Reforma da Constituição e processo: promessas e perspectivas", in Revista da Procuradoria Geral do Estado de São Paulo, 61/62, janeiro-dezembro de 2005, p. 8.

${ }^{294}$ Cfr. GAJARDONI, Francisco da Fonseca. "O princípio constitucional da tutela jurisdicional sem dilações indevidas e o julgamento antecipadíssimo da lide", in Revista IOB de Direito Civil e Processual Civil, n. 45, jan-fev. de 2007, pp. 103 e 109.
} 
são as condições que o magistrado possui de oferecer uma tutela jurisdicional de qualidade $^{295}$.

Dessa forma, as sentenças parciais se mostram não apenas como possíveis, mas sim como verdadeira necessidade, à luz do direito constitucional à razoável duração do processo ${ }^{296}$, o qual traz como consequência a impossibilidade de o juiz adiar a concessão da tutela jurisdicional depois de já ter formado sua convicção. Impossibilitar a fragmentação do julgamento da demanda, na hipótese de parcela do objeto processual encontrar-se pronta para imediata decisão, implica inequívoca dilação temporal indevida, afrontando ao art. 5 , LXXVIII, da Constituição Federal ${ }^{297}$.

\subsection{LIMITES}

A justificativa para a desacumulação de demandas por meio da cisão do julgamento de mérito é intimamente ligada aos motivos que levam à própria cumulação, seja inicial ou ulterior.

Tendo em mira um imperativo de economicidade, a parte opta por jungir demandas num mesmo processo. Se por meio de processo único é possível obter solução para os conflitos de interesse existentes, com a prolação de uma só sentença abrangendo a integralidade os pedidos formulados, não há sentido em ajuizar diversas ações ${ }^{298}$. É indiscutível a economia processual alcançada ao se permitir a resolução de várias lides sem a necessidade de uma multiplicidade de processos ${ }^{299}$.

Através do cúmulo de ações obtém-se uma sensível redução nas despesas do processo, facilitando significativamente o acesso ao Judiciário.

${ }^{295}$ Cfr. GAJARDONI, Francisco da Fonseca. "O princípio constitucional da tutela jurisdicional sem dilações indevidas e o julgamento antecipadíssimo da lide", in Revista IOB de Direito Civil e Processual Civil, n. 45, jan-fev. de 2007, pp. 107-108.

${ }^{296}$ Cfr. FONSECA, Rodrigo Garcia da. "A arbitragem e a reforma processual da execução", in Revista de Arbitragem e Mediação, n. 14, RT, São Paulo, jul-set./2007, p. 38.

${ }^{297}$ Cfr. MARINONI, Luiz Guilherme. "Técnica processual e tutela dos direitos", RT, São Paulo, 2004, p. 143.

${ }^{298}$ Cfr. TEIXEIRA, Guilherme Puchalski. "Sentenças objetivamente complexas: impossibilidade do trânsito em julgado parcial", in Revista de Processo n. 162, RT, São Paulo, agosto de 2008, p. 238.

${ }^{299}$ Cfr. ARMELIN, Donaldo. "Notas sobre sentença parcial e arbitragem", in Revista de Mediação e Arbitragem, n. 18, julho a setembro de 2008, p. 280. 
A reunião, num mesmo processo, de demandas que podem ser julgadas em conjunto possibilita a prática uma única vez de atos processuais a elas comuns (v.g., inquirição de testemunhas, vistorias, perícias, diligências de oficial de justiça). Inegável o ganho de celeridade, já que viabiliza a realização de menor quantidade de atos judiciais para se alcançar o mesmo objetivo.

Assim, um único instrumento pode servir de veículo a várias pretensões ${ }^{300}$, as quais, via de regra, devem ser instruídas e julgadas simultaneamente ${ }^{301}$.

Esta necessidade - ao menos inicial - de julgamento simultâneo é decorrência de outro importante fundamento ligado à cumulação de demandas: a harmonia entre julgados. Busca-se evitar a prolação de decisões judiciais contraditórias acerca de pedidos conexos, situação que gera sentimento de injustiça e, consequentemente, de descrédito do Poder Judiciário ${ }^{302}$.

Diante disso, é bastante tranquila a afirmação de que o fenômeno em tela não se funda exclusivamente na conveniência das partes, havendo a presença de relevante interesse público ${ }^{303}$.

E é sob o viés tanto do interesse público quanto do interesse privado que se deve considerar a possibilidade de separação das demandas, na hipótese de o caso concreto demonstrar que o julgamento conjunto não é a melhor opção.

\footnotetext{
${ }^{300}$ Cfr. MALUF, Carlos Alberto Dabus. "Cumulação de ações no processo civil", in Revista de Processo n. 17, RT, São Paulo, jan.-mar./1980, p. 61.

${ }^{301}$ Cfr. GRECO, Leonardo. "Concurso e cumulação de açães", in Revista de Processo, n. 147, RT, São Paulo, maio de 2007, pp. 14-15.

${ }^{302}$ Cfr. GRECO, Leonardo. "Concurso e cumulação de açães", in Revista de Processo, n. 147, RT, São Paulo, maio de 2007, p.15; v. tb. MALUF, Carlos Alberto Dabus. "Cumulação de ações no processo civil', in Revista de Processo n. 17, RT, São Paulo, p. 77.

${ }^{303}$ Cfr. MALUF, Carlos Alberto Dabus. "Cumulação de ações no processo civil", in Revista de Processo n. 17, RT, São Paulo, p. 77; v. tb. Cfr. CAZETTA JÚNIOR, José Jesus. "Cumulação simples de pedidos e julgamento incompleto do recurso especial: variações em tono de uma questão polêmica", in CRUZ E TUCCI, José Rogério (coord.); BEDAQUE José Roberto dos Santos (coord.). "Causa de pedir e pedido no processo civil (questões polêmicas)", RT, São Paulo, 2002, p. 438.
} 
Nesse sentido, se parcela do objeto do processo encontrase pronta para imediato julgamento, ao passo que a outra parte necessita de maior dilação probatória, a desacumulação se mostra medida de expressão da própria economia anteriormente visada, já que reduz sensivelmente o tempo de tramitação processual em relação a fração da demanda. Contudo, a análise não se esgota no maior ganho de celeridade, devendo ser considerada, ainda, a desejada harmonia entre as decisões proferidas pelo Judiciário.

Importante notar que a desacumulação de demandas não é novidade no sistema processual brasileiro. É normal que no processo haja a exclusão de parcela das demandas cumuladas, prosseguindo seu curso em relação às demais. Tratase de fenômeno inverso ao do cúmulo ulterior de demandas, podendo ocorrer, por iniciativa do autor, por ato bilateral das partes ou por imposição do juiz ${ }^{304}$.

O demandante pode desistir parcialmente da ação, reduzindo a quantidade de pedidos cumulados, afastando algum dos fundamentos invocados ou excluindo algum dos litisconsortes passivos. Também é possível que um dos autores exclua a si próprio da relação jurídica processual. Destarte, por iniciativa do autor pode haver a redução ou extinção do cúmulo, tanto no tocante a aspectos objetivos quanto a subjetivos ${ }^{305}$.

Pode, ainda, ocorrer separação de demandas por consenso entre os sujeitos processuais. O exemplo mais claro é a hipótese de celebração de transação quanto a uma das pretensões deduzidas, prosseguindo o processo em relação às demais ${ }^{306}$.

Por sua vez, o juiz tem o poder de reduzir ou extinguir o cúmulo existente, em diversas situações. De acordo com CÂNDIDO RANGEL DINAMARCO "pode, logo ao despachar a petição inicial ou depois, excluir algum dos litisconsortes ou algum dos pedidos formulados pelo autor, ou declarar que um dos fundamentos é

\footnotetext{
304 Cfr. DINAMARCO, Cândido Rangel. "Instituições de direito processual civil", v. II, 6a ed., Malheiros, São Paulo, 2009, p. 183.

305 Cfr. DINAMARCO, Cândido Rangel. "Instituições de direito processual civil", v. II, $6^{\mathrm{a}}$ ed., Malheiros, São Paulo, 2009, p. 183.

${ }_{306}$ Cfr. DINAMARCO, Cândido Rangel. "Instituições de direito processual civil", v. II, 6a ed., Malheiros, São Paulo, 2009, p. 184.
} 
impertinente ou insuscetivel de ser utilizado (erro essencial quanto ao outro cônjuge, alegado em ação de separação judicial). Pode indeferir a reconvenção ou a ação declaratória incidental, sem indeferir a inicial, ou vice-versa (art. 317) etc."307.

Nessa linha, se parcela da demanda encontrar-se madura para julgamento, seja em relação a litisconsortes, seja no tocante a pedidos, o juiz poderá e deverá efetuar a extinção ou a redução do cúmulo existente, proferindo sentença parcial de mérito. Quanto à exclusão de fundamentos, a questão é mais delicada e, portanto, será analisada em tópico separado.

Dessa forma, para que se admita o julgamento fracionado do mérito, é indispensável que o objeto do processo seja complexo, em razão de cumulação de pedidos, ou que o pedido único formulado seja decomponível ${ }^{308}$. Afigurase possível e necessário admitir o desmembramento do objeto litigioso do processo, caso seja possível dividi-lo em frações autônomas, não havendo se falar em error in procedendo $^{309}$.

Sendo assim, é necessário analisar cada uma das hipóteses em que, em tese, é viável a cisão do julgamento do mérito, iniciando o estudo pelo pedido decomponível e, em seguida, passando às diversas modalidades de cumulação de demandas.

Tem-se que o objeto do processo será decomponível sempre que o bem da vida discutido no processo o for. Também será dotado de tal característica quando se mostrar possível conceder ao autor menos do que ele pretende, como ocorre com as coisas passíveis de serem dimensionadas pelo peso, extensão ou quantidade.

\footnotetext{
${ }^{307}$ Cfr. "Instituições de direito processual civil", v. II, 6a ed., Malheiros, São Paulo, 2009, p. 184.

${ }^{308} \mathrm{Cfr}$. OLIANI, José Alexandre Manzano. "Cumprimento da sentença interlocutória que condena ao pagamento de soma, de acordo com a Lei 11.232/05", in SANTOS, Ernane Fidélis (coord.); WAMBIER, Luiz Rodrigues (coord.); NERY JR., Nelson (coord.); WAMBIER, Teresa Arruda Alvim (coord.). Execução civil: estudos em homenagem ao professor Humberto Theodoro Júnior, RT, São Paulo, 2007, p. 180.

${ }^{309}$ Cfr. ARAÚJO, José Henrique Mouta. "Coisa julgada progressiva \& resolução parcial do mérito", Juruá, Curitiba, 2008, p. 236.
} 
Trata-se de divisão ideal do objeto do processo, o qual, embora simples, é tido como sendo formado pela justaposição de duas ou mais pretensões, que gerarão capítulos de sentença decorrentes dessa decomposição ideológica: o juiz julga uma procedente, e a outra improcedente ${ }^{310}$.

O exemplo clássico de objeto processual simples decomponível é indicado nas demandas versando bem fungíveis (v.g., dinheiro), naturalmente suscetíveis de serem quantificados unitariamente ${ }^{311}$.

A decomponibilidade do objeto processual também ocorre na hipótese de ser divisível o bem da vida pleiteado, nos termos do Código Civil. São diviseis os bens passíveis de fracionamento, "sem alteração na sua substância, diminuição considerável de valor ou prejuízo do uso a que se destinam”, ao passo que são indivisíveis as coisas que "não se podem partir sem dano" (art. 87, do Código Civil), bem como aquelas cuja divisão for proibida pela lei.

Assim, a indivisibilidade pode ser física (v.g., um cavalo) ou jurídica (v.g., módulo rural). Sempre que não estiver presente qualquer destas hipóteses de indivisibilidade, é viável a decomposição ideológica do objeto do processo, sendo possível reconhecer que possui direito apenas a uma parte daquilo que foi pleiteado $^{312}$.

Cada parcela do objeto decomposto configura uma unidade autônoma, compondo, ao final, um capítulo da sentença de mérito. Destarte, se a cisão ideal do objeto processual simples pode ocorrer em capítulos diversos e autônomos, nada impede seja realizada por meio de decisões separadas, na hipótese de amadurecimento antecipado de parcela ideal do pedido.

Já aproveitando para citar comum exemplo de sua ocorrência, é cediço que essa modalidade de antecipação é prevista expressamente no

\footnotetext{
${ }^{310}$ Cfr. DINAMARCO, Cândido Rangel. "Capítulos de sentença", $4^{\mathrm{a}}$ ed., Malheiros, São Paulo, 2009, pp. 70-71.

${ }^{311}$ Cfr. DINAMARCO, Cândido Rangel. "Capítulos de sentença", $4^{\mathrm{a}}$ ed., Malheiros, São Paulo, 2009, p. 71.

${ }^{312}$ Cfr. DINAMARCO, Cândido Rangel. "Capítulos de sentença", $4^{\mathrm{a}}$ ed., Malheiros, São Paulo, 2009, pp. $72-73$.
} 
Código de Processo Civil italiano. De acordo com NeLSON NERY JUnIOR, "havendo admissão parcial da pretensão pelo réu, quando, por exemplo, o autor pede 200 e o réu admite a dívida, mas diz que o valor é de 100, na verdade há parte da pretensão sobre a qual não houve controvérsia. Nada obsta que o autor peça o adiantamento da parte incontrovertida, sob a forma de tutela antecipatória, como, aliás bem previsto no art. 186-bis do Código de Processo Civil italiano, introduzido pela reforma que ocorreu naquele país em 1990"313.

Por sua vez, em relação à cumulação de demandas, é possível encontrar na doutrina duas principais classificações ${ }^{314}$.

A primeira delas, tendo por base o elemento diverso nas ações cumuladas, divide as acumulações em objetiva, se o elemento cumulado for o pedido ou a causa de pedir (v.g., cúmulo alternativo de pedidos), ou subjetiva, quando o elemento cumulado se relacionar aos sujeitos processuais parciais (v.g., litisconsórcio) ${ }^{315}$.

Já a segunda, adotando o critério diferenciador do momento em que se forma a cumulação, classifica-a em inicial, se trazida pelo autor na exordial, ou ulterior, caso introduzida em outro momento processual, seja por iniciativa do réu (v.g., reconvenção), de terceiro (v.g., assistência litisconsorcial), ou do próprio

\footnotetext{
${ }^{313}$ Cfr. "Atualidades sobre o processo civil: a reforma do Código de Processo Civil brasileiro de 1994 e de 1995", 2ª ed., RT, São Paulo, 1996, pp. 70-71.

${ }^{314}$ Existem outras classificações, como a proposta com base na natureza do liame entre os pedidos cumulados ou na inexistência de relação entre eles. Por tal viés, as cumulações podem ser simples, condicionais e subordinadas. Na cumulação simples não há qualquer vínculo entre os pedidos. Na cumulação condicional, o vínculo é de exclusão recíproca, de modo que o autor deve fixar a prioridade na ordem de julgamento. Na cumulação subordinada, há dependência lógica entre as pretensões formuladas, seja porque o acolhimento de uma implica a procedência da outra, seja porque a decisão de uma predetermina o resultado do julgamento da outra (ou seja, há prejudicialidade) (Cfr. CAZETTA JÚNIOR, José Jesus. "Cumulação simples de pedidos e julgamento incompleto do recurso especial: variações em tono de uma questão polêmica", in CRUZ E TUCCI, José Rogério (coord.); BEDAQUE José Roberto dos Santos (coord.). "Causa de pedir e pedido no processo civil (questões polêmicas)", RT, São Paulo, 2002, p. 439).

315 Cfr. LEONEL, Ricardo de Barros. "Objeto litigioso do processo e o princípio do duplo grau de jurisdição", in CRUZ E TUCCI, José Rogério (coord.); BEDAQUE José Roberto dos Santos (coord.). "Causa de pedir e pedido no processo civil (questões polêmicas)", RT, São Paulo, 2002, p. 368.
} 
autor (v.g., ação declaratória incidental), podendo se relacionar, em qualquer destes casos, a elementos subjetivos ou objetivos da demanda ${ }^{316}$.

Para o presente trabalho interessa mais a primeira classificação, pois a possibilidade de fracionamento do julgamento do mérito tem mais relação com a natureza do elemento cumulado do que com o momento em que a cumulação ocorre.

Imagine-se que o autor, na inicial, formulou pedido de condenação do réu ao pagamento de indenização e à devolução da coisa. Resta demonstrado que ele tem direito à devolução, enquanto a indenização é controvertida, exigindo maior instrução probatória. Nada obsta seja proferida sentença parcial concedendo-lhe, desde logo e com vocação de solução definitiva, a devolução pleiteada. Contudo, se inicialmente o autor houvesse pedido somente indenização, e antes da citação - ou, então, antes do saneamento, com a concordância do réu - incluísse mais um pedido, envolvendo a devolução da coisa, e se seu direito em relação ao pedido cumulado ulteriormente estivesse demonstrado, nada impediria a cisão do julgamento do mérito.

Assim, é de se notar que o emprego do julgamento fracionado do mérito incide independentemente de se tratar de cúmulo inicial ou posterior de demandas ${ }^{317}$, bastando, a princípio, que, no momento de sua aplicação, o objeto processual apresente-se complexo ou passível de decomposição em frações ideais autônomas.

Assim, pouco importa se o pedido foi formulado desde o início do processo contra determinado sujeito processual, ou se, ao revés, o pedido ou a parte contra quem é dirigido foram introduzidos em momento processual posterior. Interessa, sim, se poderá ser julgado antes do restante do objeto processual.

\footnotetext{
${ }^{316}$ Cfr. GRECO, Leonardo. "Concurso e cumulação de ações", in Revista de Processo, n. 148, RT, São Paulo, junho de 2007, p. 15.

${ }^{317}$ Cfr. SOUZA JUNIOR, Sidney Pereira de. "Sentenças parciais no processo civil - consequências no âmbito recursal”, Método, São Paulo, 2009, p. 91.
} 
Dessa forma, é relevante não o momento da cumulação, mas sim se esta permite a alteração no momento de prolação da decisão. Analisar-se-á, portanto, a viabilidade da cisão do julgamento de mérito à luz dascumulações objetiva (causa de pedir e pedido) e subjetiva (partes) de demandas.

Dito isto, tem-se que a cumulaçãopode ser objetiva ou subjetiva. No primeiro caso, há pluralidade de demandas contra uma ou mais pessoas, ou seja, há mais de uma causa de pedir ou mais de um pedido. No segundo caso, ocorre uma pluralidade de sujeitos em um ou em ambos os polos da relação jurídica processual $^{318}$.

A cumulação objetiva de demandas pode ocorrer por cúmulo de pedidos ou de fundamentos ${ }^{319}$. Entretanto, o cúmulo objetivo por multiplicidade de fundamentos não dá ensejo à complexidade do objeto do processo, visto que, embora vários as razões de fato e de direito invocadas, o resultado útil do processo na vida dos litigantes é sempre um só ${ }^{320}$.

O cúmulo de pedidos, por sua vez, pode ser simples, alternativo, sucessivo ou eventual, devendo atender aos requisitos previstos no art. 292, do Código de Processo Civil: (i) compatibilidade entre pedidos; (ii) unidade de competência absoluta; e (iii) unidade de procedimento ${ }^{321}$.

Ocorre cúmulo subjetivo na hipótese de uma só demanda ser deduzida por e/ou contra mais de um sujeito processual. Pode ser verificado no litisconsórcio, na denunciação da lide, na oposição interventiva, etc. ${ }^{322}$.

\footnotetext{
318 Cfr. SOUZA JUNIOR, Sidney Pereira de. "Sentenças parciais no processo civil - consequências no âmbito recursal", Método, São Paulo, 2009, p. 53.

319 Cfr. DINAMARCO, Cândido Rangel. "Instituições de direito processual civil", v. II, $6^{\mathrm{a}}$ ed., Malheiros, São Paulo, 2009, p. 168.

320 Cfr. DINAMARCO, Cândido Rangel. "Instituições de direito processual civil", v. II, $6^{\mathrm{a}}$ ed., Malheiros, São Paulo, 2009, p. 197.

${ }^{321}$ Cfr. GRECO, Leonardo. "Concurso e cumulação de ações", in Revista de Processo, n. 148, RT, São Paulo, junho de 2007, p. 17.

322 Cfr. DINAMARCO, Cândido Rangel. "Instituições de direito processual civil", v. II, 6a ed., Malheiros, São Paulo, 2009, p. 168.
} 
Nesse diapasão, é possível perceber que as várias modalidades de cumulação objetiva e subjetiva de demandas se relacionam. Normalmente, o cúmulo subjetivo vem acompanhado de uma acumulação objetiva, não obstante seja prescindível a manifestação concomitante dos fenômenos ${ }^{323}$.

De qualquer forma, nessas situações haverá tantos capítulos na sentença quantas forem as demandas cumuladas, variando apenas o grau de intensidade da influência do julgamento de uma sobre os demais ${ }^{324}$.

Nessa linha, à semelhança do que ocorre na hipótese de objeto processual decomponível, se a sentença que julga todas as ações cumuladas pode ser dividida em partes autônomas, é perfeitamente viável que tais parcelas sejam analisadas em decisões autônomas, em sentenças parciais. Resta, no entanto, verificar se a técnica do julgamento fracionado pode ser aplicada em qualquer situação, ou se, ao revés, o aludido grau de intensidade na influência de uma decisão sobre a outra tem o condão de impedir a cisão do exame de mérito.

\subsubsection{CUMULACÃO SUBJETIVA DE DEMANDAS}

A cumulação sob o prisma subjetivo ocorre nas hipóteses em que há uma dilatação dos polos ativo ou passivo da demanda. Verifica-se em diversas situações, sendo as mais comumente indicadas o litisconsórcio, a denunciação da lide, o chamamento ao processo, a assistência, a oposição interventiva, o recurso de terceiro prejudicado, os embargos de terceiro, etc. ${ }^{325}$.

No cúmulo subjetivo, há uma pluralidade de autores e/ou de réus, sendo que as demandas deduzidas se desdobram em relação a cada um dos

\footnotetext{
323 Cfr. LEONEL, Ricardo de Barros. "Objeto litigioso do processo e o princípio do duplo grau de jurisdição", in CRUZ E TUCCI, José Rogério (coord.); BEDAQUE José Roberto dos Santos (coord.). "Causa de pedir e pedido no processo civil (questões polêmicas)", RT, São Paulo, 2002, p. 368.

${ }^{324}$ Cfr. DINAMARCO, Cândido Rangel. "Capítulos de sentença”, 4ª ed., Malheiros, São Paulo, 2009, p. 65.

${ }^{325}$ Cfr. LEONEL, Ricardo de Barros. "Objeto litigioso do processo e o princípio do duplo grau de jurisdição", in CRUZ E TUCCI, José Rogério (coord.); BEDAQUE José Roberto dos Santos (coord.). "Causa de pedir e pedido no processo civil (questões polêmicas)", RT, São Paulo, 2002, p. 368.
} 
sujeitos processuais, visto que o juiz poderá decidir de forma diferente em relação a cada um dos sujeitos processuais. Dessa forma, haverá, via de regra, uma concomitante cumulação objetiva de demandas, ainda que seja formulado pedido único por vários autores e/ou contra vários réus.

Exemplificando, no litisconsórcio passivo comum (seja facultativo ou necessário), é perfeitamente possível que o juiz condene um dos réus a pagar indenização pelos danos materiais causados, enquanto considere que o outro não foi responsável pelo acidente automobilístico.

Ainda nesse cenário, caso tenha havido denunciação da lide promovida à seguradora por um dos réus, nada impede que o juiz o condene no pagamento da indenização, mas julgue improcedente a demanda secundária, exonerando a denunciada do dever de pagar qualquer indenização.

Destarte, em regra, a cumulação subjetiva de demandas, seja inicial ou ulterior, sempre vem acompanhada de um cúmulo objetivo (formando objeto processual complexo), de modo que o juiz, ao decidir, poderá adotar soluções autônomas e diferentes em relação a cada litisconsorte ou sujeito processual, proferindo, assim, sentença com capítulos perfeitamente identificáveis ${ }^{326}$.

Sendo possível a adoção de solução diversa para cada sujeito processual, nada impede que o magistrado cinda o julgamento do mérito, caso o pedido formulado se mostre maduro para julgamento em relação a parcela dos sujeitos processuais. Nessa linha, verificada a possibilidade de redução ou até mesmo de extinção do cúmulo subjetivo, deve o magistrado proferir sentença parcial de mérito, entregando de forma imediata a tutela jurisdicional pleiteada, prosseguindo o processo em relação aos demais litisconsortes.

Exemplificando: autor ajuíza ação de declaratória de inexigibilidade de débito contra dois réus, sob o fundamento de ter ocorrido a prescrição da pretensão à satisfação da obrigação. No entanto, verifica-se desde logo que um dos

\footnotetext{
${ }^{326}$ Cfr. SOUZA JUNIOR, Sidney Pereira de. "Sentenças parciais no processo civil - consequências no âmbito recursal”, Método, São Paulo, 2009, pp. 71-72.
} 
requeridos é menor absolutamente incapaz, mostrando-se manifestamente improcedente o pedido declaratório em relação a ele. Em face de tal situação, deve o juiz proferir sentença parcial de mérito, julgando improcedente o pedido formulado contra o menor, seguindo o processo quanto ao outro demandado, com a consequente extinção do cúmulo subjetivo inicialmente formado.

No entanto, a regra geral acima identificada encontra importante exceção no litisconsórcio unitário. Tal modalidade de litisconsórcio impõe ao magistrado que adote idêntica solução para todos os litisconsortes, de modo que não haverá a divisão da decisão em capítulos diversos, sendo irrelevante ser facultativo ou necessário o litisconsórcio ${ }^{327}$. Assim, embora exista pluralidade de sujeitos em um dos polos da relação jurídica processual, haverá demanda única, visto que a relação jurídica de direito material é uma só. Inexiste, portanto, objeto processual complexo, sendo que a sentença proferida conterá apenas um capítulo de mérito ${ }^{328}$.

Diante disso, não é viável a cisão do julgamento de mérito, proferindo-se sentença parcial para analisar fração da demanda correspondente a apenas um dos litisconsortes, visto que a decisão há de ser necessariamente una. Em outras palavras, não se pode julgar a demanda (ou parte dela) apenas em relação a um dos litisconsortes, prosseguindo o processo em relação aos demais.

Entretanto, nada obsta o fracionamento do julgamento do mérito na hipótese de o objeto processual ser ideologicamente decomponível. Nesse caso, é possível seja proferida sentença parcial de mérito concedendo ou negando apenas parte do objeto litigioso do processo, desde que a decisão abrangendo esta parcela seja idêntica para todos os integrantes do litisconsórcio unitário. Destarte, é possível que se julgue parcela da demanda em relação a todos os litisconsortes, prosseguindo o processo - sem qualquer redução do cúmulo subjetivo - em relação ao objeto processual ainda não analisado.

${ }^{327}$ Cfr. DINAMARCO, Cândido Rangel. "Capítulos de sentença", $4^{\mathrm{a}}$ ed., Malheiros, São Paulo, 2009, pp. 69-70.

${ }^{328}$ Cfr. SOUZA JUNIOR, Sidney Pereira de. "Sentenças parciais no processo civil - consequências no âmbito recursal”, Método, São Paulo, 2009, pp. 71-72. 
Imagine-se que dois coproprietários de imóvel ajuízem ação reinvidicatória contra terceiro que injustamente deteria o bem. No curso da demanda, as partes celebram transação, reconhecendo a propriedade do réu em relação a parcela do imóvel, mas insistem em continuar o litígio em relação à parte não alcançada pelo aludido negócio jurídico. Diante disso, não obstante unitário o litisconsórcio e, portanto, único o objeto litigioso do processo, nota-se que por ser este decomponível, é perfeitamente possível proferir sentença parcial de mérito em relação à fração da demanda já madura para julgamento.

Sendo assim, no litisconsórcio unitário, a decisão parcial de mérito não pode implicar redução ou extinção do cúmulo subjetivo, sob pena de violação à regra de uniformidade de julgamento, mas nada impede que seja proferido tão-somente no tocante à parcela do objeto processual passível de decomposição ideal.

\subsubsection{CUMULACÃ̃ DE PEDIDOS}

Quanto à cumulação de pedidos, a depender de sua natureza, o autor poderá pretender a procedência de todas as demandas cumuladas ou de apenas algumas. Diante disso, a doutrina construiu classificação dividindo-a em própria e imprópria.

É própria nas hipóteses em que se formula mais de um pedido, desejando-se o acolhimento de todos eles ${ }^{329}$. O autor formula uma pluralidade de demandas contra o mesmo réu, sendo todas somadas.

Esta espécie pode ser subdividida em cumulação simples, na qual o juiz decide livremente, sem que o resultado de uma influa no da outra, e

\footnotetext{
${ }^{329}$ Cfr. CRUZ E TUCCI, José Rogério. "Reflexões sobre a cumulação subsidiária de pedidos", in CRUZ E TUCCI, José Rogério (coord.); BEDAQUE José Roberto dos Santos (coord.). "Causa de pedir e pedido no processo civil (questões polêmicas)”, RT, São Paulo, 2002, pp. 281-282; v. tb. DIDIER JR., Fredie. "Ações concorrentes. Prejudicialidade e preliminaridade. Conexão. Suspensão do processo. Litispendência. Continência. Cumulação subsidiária de pedidos. Cumulação ulterior de pedidos. Honorários advocatícios", in Revista Forense, n. 385, Forense, Rio de Janeiro, maio-jun/2006, pp. 237238.
} 
sucessiva, na qual o resultado do primeiro pedido é prejudicial em relação ao julgamento do segundo ${ }^{330}$.

Já na imprópria, devido a circunstâncias presentes no direito material discutido, a procedência de uma pretensão exclui a das demais ${ }^{331}$. Nesse sentido, busca-se o acolhimento de apenas um dos pedidos formulados, com ou sem grau de preferência pela parte que a deduz (respectivamente, cumulação eventual ou subsidiária e cumulação alternativa) $)^{332}$.

Nas cumulações impróprias, os pedidos não se acrescentam, mas se substituem, visto que apenas um deles será acolhido ${ }^{333}$. A integral solução do litígio pode ocorrer de diferentes maneiras, ficando ora a cargo de opção do julgador, observada a ordem preferencial estabelecida pelo postulante (cumulação eventual), ora por conta de uma das partes (cumulação alternativa) ${ }^{334}$.

Há na doutrina quem entenda que somente pode haver a cisão do julgamento do mérito no caso de cumulação simples, visto que inexistiria qualquer grau de dependência entre os pedidos, de modo que o acolhimento ou a rejeição de um não implicaria qualquer decisão acerca dos demais ${ }^{335}$.

Concorda-se que nesta modalidade de cumulação há o mais fértil campo de aplicação da técnica da cisão do julgamento de mérito, justamente

\footnotetext{
${ }^{330}$ Cfr. LEONEL, Ricardo de Barros. "Objeto litigioso do processo e o princípio do duplo grau de jurisdição", in CRUZ E TUCCI, José Rogério (coord.); BEDAQUE José Roberto dos Santos (coord.). "Causa de pedir e pedido no processo civil (questões polêmicas)", RT, São Paulo, 2002, p. 369.

${ }^{331}$ Cfr. CRUZ E TUCCI, José Rogério. "Reflexões sobre a cumulação subsidiária de pedidos", in CRUZ E TUCCI, José Rogério (coord.); BEDAQUE José Roberto dos Santos (coord.). "Causa de pedir e pedido no processo civil (questões polêmicas)", RT, São Paulo, 2002, pp. 281-282.

${ }_{332}$ Cfr. DIDIER JR., Fredie. "Ações concorrentes. Prejudicialidade e preliminaridade. Conexão. Suspensão do processo. Litispendência. Continência. Cumulação subsidiária de pedidos. Cumulação ulterior de pedidos. Honorários advocatícios", in Revista Forense, n. 385, Forense, Rio de Janeiro, maiojun/2006, pp. 237-238.

${ }_{333}$ Cfr. ARAÚJO, José Henrique Mouta. "Coisa julgada progressiva \& resolução parcial do mérito", Juruá, Curitiba, 2008, p. 208.

${ }^{334}$ Cfr. LEONEL, Ricardo de Barros. "Objeto litigioso do processo e o princípio do duplo grau de jurisdição", in CRUZ E TUCCI, José Rogério (coord.); BEDAQUE José Roberto dos Santos (coord.). "Causa de pedir e pedido no processo civil (questões polêmicas)", RT, São Paulo, 2002, p. 369.; v. tb. SOUZA, Rubens Hess Marins de. "A cumulação de demandas no processo civil de conhecimento", in Revista Forense, n. 382, Forense, Rio de Janeiro, nov-dez/2005, p. 39.

${ }_{335}$ Cfr. DORIA, Rogéria Dotti. "A tutela antecipada em relação à parte incontroversa da demanda", RT, São Paulo, 2004, p. 114.
} 
em razão da absoluta autonomia entre os pedidos formulados. Entretanto, conforme se verá, a prolação de sentença parcial de mérito pode ser empregada com maior grau de extensão.

\section{a) CUMULACÃ̃ SIMPLES}

Simples é a cumulação de pedidos autônomos, cuja solução de um independe da resolução dos demais, sendo julgados como se não tivessem sido formulados em conjunto, já que o exame de um deles não determina nem condiciona a análise dos outros ${ }^{336}$. Há duas ou mais pretensões justapostas, buscando o autor seu acolhimento num só processo, ma sem que entre elas haja qualquer preordenação lógica ${ }^{337}$.

Nesse sentido, são absolutamente independentes e autônomos os pedidos formulados ${ }^{338}$, devendo o juiz manifestar-se sobre todos, da forma como bem e motivadamente entender, visto que o resultado de um não influi no julgamento dos demais. Existe apenas uma característica em comum entre as demandas em cúmulo simples: as partes. Seu conteúdo e extensão são diversos, de modo que a reunião no mesmo processo somente foi possível por dizerem respeito aos mesmos sujeitos ativo e passivo ${ }^{339}$.

Exemplos: o autor discute diversos contratos de mútuo contra o mesmo réu, celebrados em momentos diferentes e fundados em causas de pedir diversas $^{340}$; indenização por lucros cessantes e danos emergentes ${ }^{341}$.

\footnotetext{
${ }^{336}$ Cfr. GRECO, Leonardo. "Concurso e cumulação de ações", in Revista de Processo, n. 148, RT, São Paulo, junho de 2007, p. 17.

${ }^{337}$ Cfr. SILVA, Ovídio Araújo Baptista da. "A demanda", in SILVA, Ovídio Araújo Baptista da; GOMES, Fábio. "Teoria geral do processo civil”, $3^{\mathrm{a}}$ ed., RT, São Paulo, 2002, pp. 247-248.

${ }^{338}$ Cfr. LEONEL, Ricardo de Barros. "Objeto litigioso do processo e o princípio do duplo grau de jurisdição", in CRUZ E TUCCI, José Rogério (coord.); BEDAQUE José Roberto dos Santos (coord.). "Causa de pedir e pedido no processo civil (questões polêmicas)", RT, São Paulo, 2002, p. 369.

${ }^{339}$ Cfr. DORIA, Rogéria Dotti. "A tutela antecipada em relação à parte incontroversa da demanda", RT, São Paulo, 2004, p. 113.

${ }^{340}$ Cfr. MALUF, Carlos Alberto Dabus. "Cumulação de ações no processo civil", in Revista de Processo n. 17, RT, São Paulo, p. 66.

${ }^{341}$ Cfr. DINAMARCO, Cândido Rangel. "Capítulos de sentença", $4^{a}$ ed., Malheiros, São Paulo, 2009, p. 65.
} 
A cumulação simples representa cristalino incentivo aos princípios da economia e celeridade, além da contribuição à harmonia entre julgados. Essa modalidade de cumulação é caracterizada pelo fato de que as pretensões poderiam ser objeto de processos autônomos, mas, por conveniência do autor, foram reunidas em processo único. A autonomia entre os pedidos é ampla, podendo receber cada um deles destino diferente dos demais ${ }^{342}$.

Dessa forma, o cúmulo simples nada mais é que a soma de dois ou mais pedidos, que poderiam ser deduzidos sem processos separados. Sendo assim, a ausência de qualquer liame fático entre eles propicia ao juiz decidir livremente sobre cada $\mathrm{um}^{343}$.

Ora, diante desse alto grau de independência é induvidoso que os pedidos cumulados podem amadurecer em momentos diversos do iter procedimental. Caso um deles encontre-se pronto para julgamento antes dos demais, é imperativo que o magistrado profira sentença parcial de mérito, conferindo aos sujeitos processuais a tutela jurisdicional definitiva em relação a esta parcela da demanda.

Note-se que não há qualquer dificuldade em relação a esta modalidade de cumulação, podendo incidir o julgamento fracionado do mérito sobre qualquer dos pedidos cumulados, já que entre eles inexiste preferência ou relação de prejudicialidade.

\section{b) CUMULACÃO SUCESSIVA}

$\mathrm{Na}$ cumulação sucessiva, o autor formula dois ou mais pedidos, sendo que a apreciação dos subsequentes só ocorre se o pedido anterior for acolhido. A rejeição deste implica o não acolhimento daqueles ${ }^{344}$.

\footnotetext{
${ }^{342}$ Cfr. ARAÚJO, José Henrique Mouta. "Coisa julgada progressiva \& resolução parcial do mérito", Juruá, Curitiba, 2008, pp. 203-204.

343 Cfr. DINAMARCO, Cândido Rangel. "Instituições de direito processual civil", v. II, $6^{\mathrm{a}}$ ed., Malheiros, São Paulo, 2009, pp. 169-170.

${ }^{344}$ Cfr. GRECO, Leonardo. "Concurso e cumulação de ações", in Revista de Processo, n. 148, RT, São Paulo, junho de 2007, p. 17.
} 
Como na modalidade anterior, o requerente também espera a procedência da integralidade das demandas, com a peculiaridade acima aludida $^{345}$. Entretanto, a semelhança se encerra aí, pois é facilmente identificável certo grau de dependência entre as demandas sucessivamente cumuladas, pois a decisão acerca do segundo pedido somente se mostra possível caso o primeiro seja julgado procedente $^{346}$ (v.g., ação declaratória de paternidade cumulada com pedido de alimentos $^{347}$; pedido de perdas e danos, que somente será procedente se a pretensão de reintegração na posse for acolhida ${ }^{348}$ ).

A relação existente entre o primeiro pedido e o segundo é de prejudicialidade, de modo que os capítulos que os decidirem também serão marcados por tal relação. São pretensões conexas pela causa de pedir, pois os fundamentos da demanda prejudicial são os mesmos da prejudicada ${ }^{349}$. Muitas vezes consubstanciam-se em questões que comportariam resolução incidenter tantum, mas que, por opção do autor, são colocadas no objeto litigioso do processo ${ }^{350}$.

Trata-se de fenômeno oposto ao que se dá na cumulação alternativa eventual: lá o segundo pedido somente pode ser apreciado diante da improcedência do primeiro. No entanto, é de se notar que a procedência da primeira demanda não influencia no resultado do exame do pedido posterior ${ }^{351}$.

Destarte, é possível o acolhimento da demanda prejudicial e a rejeição da demanda prejudicada (v.g., o réu é declarado pai do autor, mas não é

\footnotetext{
${ }^{345}$ Cfr. LEONEL, Ricardo de Barros. "Objeto litigioso do processo e o princípio do duplo grau de jurisdição", in CRUZ E TUCCI, José Rogério (coord.); BEDAQUE José Roberto dos Santos (coord.). "Causa de pedir e pedido no processo civil (questões polêmicas)", RT, São Paulo, 2002, p. 369.

${ }^{346}$ Cfr. SILVA, Ovídio Araújo Baptista da."Cumulação de demandas e 'execução' de sentença constitutiva", in Da sentença liminar à nulidade da sentença, Forense, Rio de Janeiro, 2001, pp. 352-353; v. tb. DORIA, Rogéria Dotti. "A tutela antecipada em relação à parte incontroversa da demanda", RT, São Paulo, 2004, p.113.

${ }^{347}$ Cfr. MALUF, Carlos Alberto Dabus. "Cumulação de ações no processo civil”, in Revista de Processo n. 17, RT, São Paulo, p. 66.

${ }^{348}$ Cfr. DINAMARCO, Cândido Rangel. "Capítulos de sentença", 4 ed., Malheiros, São Paulo, 2009, p. 65.

${ }^{349}$ Cfr. DINAMARCO, Cândido Rangel. "Instituições de direito processual civil", v. II, $6^{\mathrm{a}}$ ed., Malheiros, São Paulo, 2009, p. 172.

${ }^{350}$ Cfr. ARAÚJO, José Henrique Mouta. "Coisa julgada progressiva \& resolução parcial do mérito", Juruá, Curitiba, 2008, pp. 206-207.

${ }^{351}$ Cfr. SILVA, Ovídio Araújo Baptista da. "A demanda", in SILVA, Ovídio Araújo Baptista da; GOMES, Fábio. "Teoria geral do processo civil”, 3ª ed., RT, São Paulo, 2002, p. 248.
} 
condenado a pagar alimentos; o contrato é declarado válido, mas o réu não é condenado, pois o autor ainda não cumpriu sua obrigação, etc.).

De outro lado, pode haver a procedência da pretensão prejudicada mesmo em face da inadmissibilidade da prejudicial, situação verificada, v.g., na falta de interesse de agir em relação à declaração de paternidade (v.g., registro de nascimento trazido aos autos), que não impede a condenação nos alimentos pleiteados.

Aceita-se, ainda, que ambas sejam consideradas inadmissíveis, ou, ainda, procedentes, parcialmente procedentes ou improcedentes. $\mathrm{O}$ que não é viável, contudo, em razão do aludido nexo de prejudicialidade, é julgar improcedente a demanda principal e procedente a prejudicada ${ }^{352}$.

Diante disso, é possível afirmar que na cumulação sucessiva de demandas, o segundo pedido manejado pelo autor não poderá ser julgado por sentença parcial de mérito, justamente em razão da estreita relação de prejudicialidade existente com o pedido primário, que ainda penderia de apreciação judicial.

Assim, o julgamento fracionado do mérito pode ter como objeto apenas o primeiro pedido, já que autônomo e prejudicial em relação ao segundo; antecipar-se o julgamento do pedido prejudicado não é possível ${ }^{353}$, visto que a controvérsia existente em relação ao primário torna logicamente insustentável o exame do pedido sucessivo ${ }^{354}$.

Exemplo relativamente atual de aplicação da técnica do julgamento fracionado do mérito em cumulação sucessiva de pedidos se verifica em relação à demanda contendo pedidos de divórcio e de fixação de outras providências (v.g., alimentos, guarda dos filhos, alteração de nome, ressarcimento de danos morais,

${ }^{352}$ Cfr. DINAMARCO, Cândido Rangel. "Instituições de direito processual civil", v. II, $6^{\mathrm{a}}$ ed., Malheiros, São Paulo, 2009, p. 173.

353 Cfr. SOUZA JUNIOR, Sidney Pereira de. "Sentenças parciais no processo civil - consequências no âmbito recursal", Método, São Paulo, 2009, pp. 100-101.

${ }^{354}$ Cfr. ZAVASCKI, Teori Albino. "Antecipação da tutela em face de pedido incontroverso", in Revista Jurídica, n. 301, novembro de 2002, p. 33. 
etc.), na qual muitas vezes se mostra necessário o exame da culpa pelo rompimento da sociedade conjugal.

$\mathrm{O}$ advento da EC n. 66/10 trouxe profundas alterações na matéria, dentre as quais a principal foi a de ter eliminado do sistema a separação judicial, de modo que os cônjuges que não mais querem continuar a viver juntos devem requerer de forma direta o divórcio. Diante disso, debatem os civilistas acerca da possibilidade de discussão de culpa na ação de divórcio, prevalecendo a corrente que defende seu não cabimento, sob a justificativa de causar indevida demora processual na resolução da questão e na colocação de um fim ao vínculo matrimonial ${ }^{355}$.

Dúvidas não há de que a culpa, não sendo requisito necessário à decretação do divórcio, pode gerar indevidos atrasos na prestação jurisdicional a ele referente. Todavia, também é certo que sua discussão pode ser imprescindível à resolução de pedidos cumulados, como a fixação de alimentos ou o ressarcimento de danos morais.

Diante disso, configura-se situação que permite a aplicação da técnica do julgamento fracionado do mérito com nítido prestígio da efetividade do processo: estando a pretensão referente ao divórcio madura para julgamento, deve o magistrado proferir sentença parcial de mérito, resolvendo definitivamente essa parcela do litígio, e determinando o prosseguimento do processo para que se instruam os demais pedidos, ocasião em que, se necessário, poderá ser discutida eventual culpa de um dos cônjuges ${ }^{356}$.

As vantagens são significativas: poder-se-á discutir culpa e demais questões que exijam dilação probatória, sem a necessidade de ajuizamento de nova ação e sem qualquer prejuízo ao célere rompimento do vínculo conjugal.

\footnotetext{
355 TARTUCE, Flávio. “Manual de direito civil”, v. único, Método, São Paulo, 2011, pp. 1075-1076.

${ }^{356}$ A jurisprudência já se mostrou sensível a tal situação, proferindo julgamento fracionado do mérito, nos seguintes termos: "incontroverso que as partes são casadas, de rigor a imediata procedência do pedido de divórcio, de acordo com o art. 226, \$6o, da CF, determinando-se o regular andamento do feito em relação aos outros capítulos. Isto porque a extinção do vínculo matrimonial e a cessação da sociedade conjugal não dependem da resolução das outras questões do processo" (cfr. AI n. 990.10.357301-3, Bauru, TJSP, $8^{\mathrm{a}}$ Câm. Dir. Priv., Rel. Des. Caetano Lagrasta, j. 10.11.10, v.u.).
} 


\section{c) CUMULAĊ̃̃O EVENTUAL}

A cumulação eventual, também chamada de subsidiária, é aquela em que há a reunião de dois ou mais pedidos, com manifestação de preferência pelo demandante em relação a um deles (pedido primário e pedido subsidiário) ${ }^{357}$.

Caracteriza-se pelo fato de o pedido subsequente somente ser passível de análise caso o antecedente seja rejeitado. Se este for acolhido, aquele será considerado prejudicado ${ }^{358}$. Dessa forma, o pedido será subsidiário sempre que sua consideração depender da eventualidade de o pedido antecedente não ser acolhido ${ }^{359}$.

Nesta modalidade de cumulação, o autor formula dois ou mais pedidos, mas reconhece que apenas um deles é substantivamente procedente ${ }^{360}$. Há, portanto, duas ou mais formas de se solucionar a crise de direito material trazida a Juízo pelo demandante, mas, em caso de procedência, apenas uma delas poderá ser determinada pelo magistrado ${ }^{361}$.

A característica definidora da cumulação alternativa eventual reside justamente no fato de serem os pedidos excludentes entre si, de modo que o demandante, ao formulá-los, escolhe algum deles como primário, indicando os outros como alternativos, cuja apreciação ocorrerá apenas na eventualidade de improcedência daquele ${ }^{362}$.

${ }^{357}$ Cfr. DINAMARCO, Cândido Rangel. "Instituições de direito processual civil", v. II, 6a ed., Malheiros, São Paulo, 2009, pp. 176-177.

${ }^{358}$ Cfr. GRECO, Leonardo. "Concurso e cumulação de ações", in Revista de Processo, n. 148, RT, São Paulo, junho de 2007, p. 17.

359 Cfr. DINAMARCO, Cândido Rangel. "Instituições de direito processual civil", v. II, 6a ed., Malheiros, São Paulo, 2009, pp. 176-177.

${ }^{360}$ Cfr. CRUZ E TUCCI, José Rogério. "Reflexões sobre a cumulação subsidiária de pedidos", in CRUZ E TUCCI, José Rogério (coord.); BEDAQUE José Roberto dos Santos (coord.). "Causa de pedir e pedido no processo civil (questões polêmicas)", RT, São Paulo, 2002, p. 282.

361 Cfr. SOUZA, Rubens Hess Marins de. "A cumulação de demandas no processo civil de conhecimento", in Revista Forense, n. 382, Forense, Rio de Janeiro, nov-dez/2005, p. 37.

${ }^{362}$ Cfr. SILVA, Ovídio Araújo Baptista da."CCumulação de demandas e 'execução' de sentença constitutiva”, in Da sentença liminar à nulidade da sentença, Forense, Rio de Janeiro, 2001, pp. 352-353. 
O Código de Processo Civil não exige compatibilidade ou nexo substancial entre os pedidos cumulados. Cada uma destas pretensões sucessivas poderia ser veiculada em processo autônomo, mas são agrupadas pelo autor em ordem determinada exclusivamente por força de seu interesse ${ }^{363}$. O que existe é um elo de prejudicialidade entre as demandas, visto que o acolhimento da primeira fulmina o interesse processual em relação à subsidiária ${ }^{364}$.

É pertinente lembrar que, não obstante de corrente uso, a melhor denominação para o pedido antecedente não é "pedido principal", visto que tal expressão faz supor a ideia de um "pedido acessório". Ocorre que o pedido subsequente não tem essa característica de acessoriedade, de modo que é mais correto adotar as expressões "pedido primário" e "pedido subsidiário"365.

Dessa forma, a cumulação eventual é aquela em que os pedidos se substituem, na ordem de sua formulação pelo demandante. Não sendo acolhido o primeiro, examina-se o segundo, e assim sucessivamente. Exemplos: pedido de restituição de coisa, ou faltando essa, indenização pelo valor equivalente; pedido para que o alienante complete a área do imóvel vendido, ou, não sendo possível, que restitua proporcionalmente parte do preço pago ${ }^{366}$; pede-se a condenação na obrigação de fazer, mas, caso esta não seja possível, requer-se o equivalente em dinheiro ${ }^{367}$, etc.

O autor pode ordenar tais pedidos com a preferência que bem entender ${ }^{368}$. Não há indiferença quanto ao resultado, visto que há uma escolha prioritária por ele realizada ${ }^{369}$.

\footnotetext{
${ }^{363}$ Cfr. LEONEL, Ricardo de Barros. "Objeto litigioso do processo e o princípio do duplo grau de jurisdição", in CRUZ E TUCCI, José Rogério (coord.); BEDAQUE José Roberto dos Santos (coord.). "Causa de pedir e pedido no processo civil (questões polêmicas)", RT, São Paulo, 2002, p. 370.

${ }^{364}$ Cfr. CRUZ E TUCCI, José Rogério. "Reflexões sobre a cumulação subsidiária de pedidos", in CRUZ E TUCCI, José Rogério (coord.); BEDAQUE José Roberto dos Santos (coord.). "Causa de pedir e pedido no processo civil (questões polêmicas)", RT, São Paulo, 2002, p. 285.

${ }^{365}$ Cfr. CRUZ E TUCCI, José Rogério. "Reflexões sobre a cumulação subsidiária de pedidos", in CRUZ E TUCCI, José Rogério (coord.); BEDAQUE José Roberto dos Santos (coord.). "Causa de pedir e pedido no processo civil (questões polêmicas)", RT, São Paulo, 2002, p. 283.

${ }^{366}$ MALUF, Carlos Alberto Dabus. "Cumulação de ações no processo civil", in Revista de Processo $\mathrm{n}$. 17, RT, São Paulo, p. 66.

${ }^{367}$ Cfr. DINAMARCO, Cândido Rangel. "Capítulos de sentença", $4^{\mathrm{a}}$ ed., Malheiros, São Paulo, 2009, p. 65.

${ }^{368}$ Cfr. CRUZ E TUCCI, José Rogério. "Reflexões sobre a cumulação subsidiária de pedidos", in CRUZ E TUCCI, José Rogério (coord.); BEDAQUE José Roberto dos Santos (coord.). "Causa de pedir e pedido no processo civil (questões polêmicas)", RT, São Paulo, 2002, p. 283.
} 
Diante disso, se o juiz acolher o pedido primário, apenas o réu terá interesse recursal. No entanto, se o pedido subsidiário foi o acolhido, haverá sucumbência recíproca, de modo que tanto autor e demandado poderão manejar recurso de apelação: o primeiro visando ao acolhimento da pretensão primária; o segundo buscando a integral improcedência da demanda ${ }^{370}$.

A hierarquia das demandas estabelecida pelo autor deverá ser observada pelo magistrado, não podendo passar à análise das posteriores sem rejeitar as anteriores, sob pena de error in procedendo. A sentença sempre deverá analisar primeiramente o pedido primário. Ainda que o réu reconheça o pedido subsidiário, ou este se encontre maduro para imediato julgamento, sua análise somente poderá ocorrer se não acolhida a primeira demanda ${ }^{371}$. Assim, não se mostra viável que o julgador profira sentença parcial de mérito em relação ao segundo pedido, já que seu exame somente se tornará possível caso o pedido primário não seja acolhido ${ }^{372}$.

Entretanto, as possibilidades não se esgotam aí. Entendese que, se o pedido primário for parcialmente procedente, deverá o juiz verificar, hipoteticamente, o resultado do julgamento da pretensão secundária. Na hipótese de esta comportar julgamento de integral procedência, considera-se que o interesse do autor estará mais bem resguardado com o acolhimento do pedido subsidiário do que com a parcial procedência do primário. Assim, se o requerente não faz jus ao recebimento da integralidade do valor, mas tem direito a obter a res de volta, deve o juiz deixar de acolher o primário, expondo suas razões, e julgar procedente o pedido subsidiário, determinando a restituição da coisa ${ }^{373}$.

369 Cfr. DINAMARCO, Cândido Rangel. "Instituições de direito processual civil", v. II, 60 ed., Malheiros, São Paulo, 2009, p. 177.

${ }^{370}$ Cfr. CRUZ E TUCCI, José Rogério. "Reflexões sobre a cumulação subsidiária de pedidos", in CRUZ E TUCCI, José Rogério (coord.); BEDAQUE José Roberto dos Santos (coord.). "Causa de pedir e pedido no processo civil (questões polêmicas)", RT, São Paulo, 2002, p. 289; v. tb. ARAÚJO, José Henrique Mouta. "Coisa julgada progressiva \& resolução parcial do mérito", Juruá, Curitiba, 2008, p. 213.

${ }^{371}$ Cfr. CRUZ E TUCCI, José Rogério. "Reflexões sobre a cumulação subsidiária de pedidos”, in CRUZ E TUCCI, José Rogério (coord.); BEDAQUE José Roberto dos Santos (coord.). "Causa de pedir e pedido no processo civil (questões polêmicas)", RT, São Paulo, 2002, pp. 286-287.

372 Cfr. SOUZA JUNIOR, Sidney Pereira de. "Sentenças parciais no processo civil - consequências no âmbito recursal", Método, São Paulo, 2009, pp. 101-102.

${ }^{373}$ Cfr. CRUZ E TUCCI, José Rogério. "Reflexões sobre a cumulação subsidiária de pedidos", in CRUZ E TUCCI, José Rogério (coord.); BEDAQUE José Roberto dos Santos (coord.). "Causa de pedir e pedido no processo civil (questões polêmicas)", RT, São Paulo, 2002, pp. 287-288. 
Mais complexa é a situação em que ambos os pedidos são parcialmente procedentes $^{374}$. Nesse caso, parece prudente que o juiz julgue parcialmente procedente o pedido que trouxer maiores vantagens práticas ao autor - que não necessariamente será o primeiro, considerando-se as variadas possibilidades envolvendo a extensão da parcial procedência.

Afirma-se que se o juiz rejeita o pedido antecedente, mas não analisa o subsequente, proferirá decisão infra petita ${ }^{375}$, e, portanto, nula ${ }^{376}$. No entanto, esta afirmação não se mostra totalmente precisa.

Diante da comprovada improcedência do pedido antecedente e da necessidade de dilação probatória do pedido subsequente, nada impede que o magistrado pronuncie a improcedência daquele por meio de sentença parcial de mérito, prosseguindo o processo em seus ulteriores termos para o julgamento do pedido subsequente ${ }^{377}$.

Ilustrando, imagine-se situação em que o autor ajuíza demanda pleiteando a devolução da coisa ou, subsidiariamente, a indenização pelosprejuízos sofridos. Há provas suficientes para embasar, por meio de cognição exauriente, a improcedência do pedido antecedente, de restituição da coisa. Contudo, há controvérsia fática a respeito do direito à indenização, que demandará a realização de

\footnotetext{
${ }^{374}$ Cfr. CRUZ E TUCCI, José Rogério. "Reflexões sobre a cumulação subsidiária de pedidos", in CRUZ E TUCCI, José Rogério (coord.); BEDAQUE José Roberto dos Santos (coord.). "Causa de pedir e pedido no processo civil (questões polêmicas)”, RT, São Paulo, 2002, p. 288.

${ }^{375}$ Cfr. DIDIER JR., Fredie. "Ações concorrentes. Prejudicialidade e preliminaridade. Conexão. Suspensão do processo. Litispendência. Continência. Cumulação subsidiária de pedidos. Cumulação ulterior de pedidos. Honorários advocatícios", in Revista Forense, n. 385, Forense, Rio de Janeiro, maiojun/2006, p. 242; v. tb. ARAÚJO, José Henrique Mouta. "Coisa julgada progressiva \& resolução parcial do mérito", Juruá, Curitiba, 2008, p.212.

${ }^{376}$ Cfr. CRUZ E TUCCI, José Rogério. "Reflexões sobre a cumulação subsidiária de pedidos", in CRUZ E TUCCI, José Rogério (coord.); BEDAQUE José Roberto dos Santos (coord.). "Causa de pedir e pedido no processo civil (questões polêmicas)", RT, São Paulo, 2002, p. 288.

${ }^{377}$ Conforme analisado no item 3.1.2, não há qualquer irregularidade no emprego desta técnica, visto que, ainda que se considerasse infra petita o indigitado ato decisório, este deveria ser mantido, porque hígido na parcela do mérito analisada, determinando-se apenas o julgamento do restante do objeto processual- $\mathrm{o}$ que aconteceria, de um jeito ou de outro -, a fim de se sanar a suposta nulidade. Nesse sentido a lição de ARNOLDO WALD, segundo a qual "quando o ato processual puder ser fracionado, a nulidade dele não se comunica às partes hígidas, de sorte que devem ser estas aproveitadas em homenagem ao princípio da instrumentalidade das formas" (cfr. "A validade da sentença arbitral parcial nas arbitragens submetidas ao regime da CCF", in Revista de Direito Bancário do Mercado de Capitais e da Arbitragem, n. 17, RT, São Paulo, julho a setembro de 2002, p. 336).
} 
custosa prova pericial. Diante disso, nada obsta que o magistrado profira sentença parcial de mérito, julgando improcedente o pedido de restituição da coisa, e determine o prosseguimento do processo para que se realize a instrução necessária à apreciação do pedido subsequente.

Neste caso, se o Tribunal vier a acolher recurso interposto pelo autor e, consequentemente, julgar procedente o primeiro pedido, haverá a perda do interesse de agir em relação ao pedido secundário, devendo o processo, quanto a ele, ser extinto sem julgamento de mérito por carência superveniente de ação ${ }^{378}$.

Não obstante óbvio, é salutar esclarecer que tal modalidade de cumulação não comporta sentença parcial de mérito de procedência do pedido antecedente, visto que o juiz, ao assim decidir, estaria proferindo sentença final, já que eventuais pedidos subsequentes restariam prejudicados, nada mais havendo a ser apreciado no processo ${ }^{379}$. Como o próprio nome desta espécie de cumulação indica, os pedidos subsequentes somente serão analisados na eventualidade da inadmissibilidade ou da improcedência do pedido antecedente ${ }^{380}$.

Nesse sentido, importante notar que somente haverá sucumbência do autor caso todos os seus pedidos sejam rejeitados, visto que é impossível o acolhimento da integralidade das pretensões por ele ajuizadas. Assim, se for julgado procedente, ainda que somente o pedido subsidiário, a sucumbência será integral do réu ${ }^{381}$. Destarte, a fixação de honorários advocatícios, na hipótese de prolação de sentença parcial - a qual, como dito, somente poderá ser de improcedência de pedido antecedente - deverá ser realizada somente na sentença final do procedimento, diante das especificidades desta espécie de cumulação.

\footnotetext{
${ }^{378}$ Cfr. SOUZA JUNIOR, Sidney Pereira de. "Sentenças parciais no processo civil - consequências no âmbito recursal”, Método, São Paulo, 2009, pp. 101-102.

${ }^{379}$ Cfr. SOUZA JUNIOR, Sidney Pereira de. "Sentenças parciais no processo civil - consequências no âmbito recursal”, Método, São Paulo, 2009, pp. 101-102.

${ }^{380} \mathrm{Cfr}$. SOUZA, Rubens Hess Marins de. "A cumulação de demandas no processo civil de conhecimento", in Revista Forense, n. 382, Forense, Rio de Janeiro, nov-dez/2005, pp. 37-38.

381 Cfr. DIDIER JR., Fredie. "Ações concorrentes. Prejudicialidade e preliminaridade. Conexão. Suspensão do processo. Litispendência. Continência. Cumulação subsidiária de pedidos. Cumulação ulterior de pedidos. Honorários advocatícios", in Revista Forense, n. 385, Forense, Rio de Janeiro, maiojun/2006, pp. 242-243.
} 


\section{d) PEDIDO ALTERNATIVO}

Por fim, a doutrina entende que nos casos de pedido alternativo, tal qual previsto no art. 288, do Código de Processo, não há qualquer espécie de cumulação de demandas ${ }^{382}$. Isto porque, não obstante sejam formulados dois pedidos, ambos se referem a uma só pretensão, já que o acolhimento de qualquer deles é suficiente à integral satisfação dos interesses do autor. Assim, inexiste cumulação ${ }^{383}$.

Nesta categoria, em razão das peculiaridades do direito material envolvido, uma das partes tem a possibilidade de cumprir sua obrigação de mais de uma maneira. Assim, somente se poderia falar em cumulação no tocante ao bem da vida (pedido mediato), mas não em relação à tutela jurisdicional (pedido

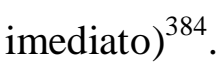

Se ao devedor couber a escolha da forma como será cumprida a obrigação, deve o autor formular o pedido na petição inicial de modo que seja assegurada ao réu a faculdade de escolher, devendo o juiz velar pela existência dessa alternatividade ${ }^{385}$.

O demandante, sem imputar qualquer hierarquia ou preferência entre os pedidos, indica que a satisfação da situação da vida buscada por meio da tutela jurisdicional pode ocorrer por mais de uma maneira. Diferentemente do cúmulo subsidiário, inexiste qualquer subordinação entre os pedidos alternativos, contendo-se o autor com a procedência de qualquer deles ${ }^{386}$. Exemplo: o autor pleiteia

\footnotetext{
${ }^{382}$ Cfr. GRECO, Leonardo. "Concurso e cumulação de açães", in Revista de Processo, n. 148, RT, São Paulo, junho de 2007, p. 17.

${ }^{383}$ Cfr. SOUZA JUNIOR, Sidney Pereira de. "Sentenças parciais no processo civil - consequências no âmbito recursal”, Método, São Paulo, 2009, p. 89.

${ }^{384}$ Cfr. LEONEL, Ricardo de Barros. "Objeto litigioso do processo e o princípio do duplo grau de jurisdição", in CRUZ E TUCCI, José Rogério (coord.); BEDAQUE José Roberto dos Santos (coord.). "Causa de pedir e pedido no processo civil (questões polêmicas)", RT, São Paulo, 2002, p. 369.

${ }^{385}$ Cfr. SILVA, Ovídio Araújo Baptista da. "A demanda", in SILVA, Ovídio Araújo Baptista da; GOMES, Fábio. "Teoria geral do processo civil”, 3ª ed., RT, São Paulo, 2002, p. 246.

${ }^{386}$ Cfr. ARAÚJO, José Henrique Mouta. "Coisa julgada progressiva \& resolução parcial do mérito", Juruá, Curitiba, 2008, p. 208.
} 
ocumprimento da obrigação mediante pagamento em dinheiro ou transferência da propriedade de determinado bem imóvel ${ }^{387}$.

Destarte, o pedido alternativo não se confunde com os pedidos alternativamente cumulados. Neste último caso há, efetivamente, uma cumulação de demandas, sendo que a segunda somente é analisada na hipótese de não acolhimento da primeira. Já no pedido alternativo, não há qualquer cúmulo: a demanda é única ${ }^{388}$.

Em face da indiferença do autor em relação a qual dos pedidos alternativos pretende seja julgado procedente, o juiz possui a liberdade de acolher qualquer deles, segundo seu motivado entendimento. Dessa forma, o acolhimento de qualquer dos pedidos é suficiente para que a demanda seja julgada integralmente procedente, e não procedente em parte ${ }^{389}$.

Sendo assim, impossível que se profira sentença parcial de procedência de qualquer dos pedidos alternativos, visto que se trataria, na verdade, de decisão final.

Entretanto, é possível imaginar a prolação de decisão parcial de improcedência de um dos pedidos alternativos (v.g., autor pleiteia o cumprimento da obrigação mediante pagamento de quantia em dinheiro ou mediante a cessão de quotas hereditárias de pessoas vivas). Neste caso, eliminar-se-ia um dos bens da vida (pedido mediato) visados pelo autor, prosseguindo o processo para o exame de seu direito à obtenção do bem da vida restante. Todavia, como a procedência de qualquer dos pedidos alternativos satisfaz integralmente a pretensão (que é única) do demandante, verifica-se que os honorários advocatícios somente deverão ser fixados ao final do processo, tendo em vista que, neste momento, não seria possível a aferição da sucumbência.

\footnotetext{
${ }^{387}$ Cfr. DINAMARCO, Cândido Rangel. "Capítulos de sentença", $4^{\mathrm{a}}$ ed., Malheiros, São Paulo, 2009, p. 65.

${ }^{388}$ Cfr. SILVA, Ovídio Araújo Baptista da. "A demanda", in SILVA, Ovídio Araújo Baptista da; GOMES, Fábio. "Teoria geral do processo civil”, 3ª ed., RT, São Paulo, 2002, p. 247.

389 Cfr. DINAMARCO, Cândido Rangel. "Instituições de direito processual civil", v. II, 6a ed., Malheiros, São Paulo, 2009, pp. 175-176.
} 
Também é possível imaginar a prolação de uma sentença parcial de mérito, caso o pedido alternativo seja decomponível, aplicando, mutatis mutandis, o quanto já dito acerca do tema.

\subsubsection{CUMULACÃO DE FUNDAMENTOS}

No cúmulo de fundamentos o autor pretende resultado prático único, consistente na obtenção do bem da vida indicado na petição inicial. Para tanto, traz um conjunto de fundamentos destinados a embasar o pedido, de modo a alargar as possibilidades de julgamento ${ }^{390}$.

Identifica-se a cumulação de fundamentos sempre que cada um deles for, de forma autônoma, apto a ensejar a conclusão de procedência da pretensão do demandante ${ }^{391}$.

Contudo, o cúmulo objetivo por multiplicidade de fundamentos não gera complexidade do objeto processual, visto que o resultado útil pretendido com o processo sempre será o mesmo ${ }^{392}$.

A doutrina alemã muito discutiu acerca do conceito de objeto do processo (Stretgegenstand), na tentativa de definir qual seria seu conteúdo. Após décadas de debates, chegou-se ao entendimento de que o objeto do processo deve ser identificado na pretensão que o demandante deduz (Anspruch), por meio do pedido (Antrag). Essa pretensão é o que se denomina mérito, e a atividade cognitiva realizada pelos sujeitos processuais é destinada a fornecer elementos que possibilitem ao juiz emitir pronunciamento que solucione a lide ${ }^{393}$.

\footnotetext{
390 Cfr. DINAMARCO, Cândido Rangel. "Instituições de direito processual civil”, v. II, 6 ${ }^{\mathrm{a}}$ ed., Malheiros, São Paulo, 2009, p. 178.

391 Cfr. DINAMARCO, Cândido Rangel. "Instituições de direito processual civil”, v. II, 6 $6^{\mathrm{a}}$ ed., Malheiros, São Paulo, 2009, p. 178.

392 Cfr. DINAMARCO, Cândido Rangel. "Instituições de direito processual civil”, v. II, 6 $6^{\mathrm{a}}$ ed., Malheiros, São Paulo, 2009, p. 197.

${ }^{393}$ Cfr. DINAMARCO, Cândido Rangel. “Capítulos de sentença”, 4ª ed., Malheiros, São Paulo, 2009, p.
} 51. 
Assim, nas palavras de CÂNDIDO RANGEl DinAmARCO, "julgar o mérito é conceder ou negar a tutela jurisdicional postulada pelo autor - no segundo caso, concedendo-a ao réu. Quer se acolha ou rejeite a demanda do autor, julgar o mérito é sempre dispor sobre a pretensão deduzida" 394.

Diante disso, conclui-se que o objeto do processo reside somente no pedido, não abarcando a causa de pedir. $\mathrm{O}$ postulante requer ao juiz situação mais favorável que a por ele descrita, e justamente na resposta judicial a este pleito é que se identifica o meritum causae. Tanto é assim que o Código expressamente determina que somente o dispositivo da sentença é apto a adquirir a imutabilidade da coisa julgada material, a qual não alcança as questões (de mérito ou processuais) resolvidas na fundamentação. É da parte dispositiva que emanam os efeitos capazes de trazer alteração à vida das pessoas ${ }^{395}$.

Dessa forma, não é possível se confundir as questões de mérito, extraídas das causas de pedir e de resistir alegadas pelas partes, que precisam ser resolvidas pelo magistrado para que este profira pronunciamento acerca da situação mais favorável pleiteada pelo demandante, com a própria decisão acerca do bem da vida visado. As questões de mérito integram o objeto de conhecimento do juiz ${ }^{396}$; já o objeto do processo limita-se à pretensão deduzida ${ }^{397}$.

É importante, ademais, anotar a existência de divergência doutrinária na atribuição de nomes a esses fenômenos. Há quem empregue a expressão objeto do processo como sinônima de objeto de conhecimento do juiz, abarcando todas as questões de mérito cuja resolução é necessária para que se profira decisão acerca da pretensão deduzida. Por sua vez, reserva-se a expressão objetolitigioso do processo para

\footnotetext{
${ }^{394}$ Cfr. "Capítulos de sentença", 4 ed., Malheiros, São Paulo, 2009, p. 51.

${ }^{395}$ Cfr. DINAMARCO, Cândido Rangel. "Capítulos de sentença”, 4ª ed., Malheiros, São Paulo, 2009, pp. 58-59.

${ }^{396}$ Mais uma vez, busca-se apoio no escólio de DinAMARCo para a precisa definição de objeto de conhecimento do juiz: "é o conjunto de todo o material lógico que o espírito deste capta e elabora de modo a saber se julgará o mérito e como o julgará" (cfr. "Instituições de direito processual civil", v. II, $6^{\mathrm{a}}$ ed., Malheiros, São Paulo, 2009, p. 191).

${ }^{397}$ Cfr. DINAMARCO, Cândido Rangel. “Capítulos de sentença”, 4ª ed., Malheiros, São Paulo, 2009, p.
} 60 . 
identificação do meritum causae, da pretensão deduzida, da situação da vida mais favorável pleiteada ${ }^{398}$.

Trata-se de cenário indesejado, visto que a diversidade de denominações torna ainda mais delicado o estudo de tema já bastante complexo ${ }^{399}$. No presente trabalho, as expressões objeto do processo e objeto litigioso do processo foram empregadas para identificar a pretensão deduzida, enquanto a expressão objeto de conhecimento do juiz foi utilizada para fazer referência às demais questões trazidas pelas partes e que deverão ser solucionadas pelo magistrado na fundamentação de sua sentença.

As questões de mérito, assim, são os fundamentos trazidos na petição inicial ou na defesa (v.g., existência ou não de culpa nos litígios envolvendo responsabilidade civil; existência ou não de pagamento em demandas versando cobrança de quantia, etc.). São matérias analisadas e solucionadas, incidenter tantum, pelo magistrado no momento de fundamentar sua sentença, não trazendo qualquer vinculação para o futuro, visto que não integram o decisum (artigos 458, II, e 469, I, do Código de Processo Civil) ${ }^{400}$.

Somente são abrangidas pela coisa julgada material as questões que integrem o objeto do processo em sentido estrito, estando fora do campo de proteção por ela oferecido aqueles pontos controvertidos que forem solucionados

\footnotetext{
${ }^{398}$ Cfr. LEONEL, Ricardo de Barros. "Objeto litigioso do processo e o princípio do duplo grau de jurisdição", in CRUZ E TUCCI, José Rogério (coord.); BEDAQUE José Roberto dos Santos (coord.). "Causa de pedir e pedido no processo civil (questões polêmicas)", RT, São Paulo, 2002, pp. 351-352.

399 Acerca da diversidade de nomenclaturas atribuídas ao fenômeno, explica DinAMARCO que: "alguns preferem dizer objeto litigioso, em vez de objeto do processo. Mas só se pode conceber em um ser a qualidade de objeto quando considerado em relação aum outro ser: nenhum ser é objeto em si mesmo. Pelo aspecto linguístico, o vocábulo alemãoStreitgegenstandautoriza as duas traduções. Da justaposição dos dois substantivosStreit (lide, processo) eGegenstand(objeto) pode resultar o entendimento de que o primeiro adjetiva o segundo (dai objeto litigioso) mas pode-se também extrair a ideia de algo que se relaciona a algo (daí, objeto do processo). Os italianos preferemoggettodel processo $e$ os autores de língua espanhola, objeto litigioso. Há também quem prefira objeto litigioso do processo" (Cfr. "Instituições de direito processual civil", v. II, $6^{\mathrm{a}}$ ed., Malheiros, São Paulo, 2009, nota 1, p. 185).

${ }^{400}$ Cfr. DINAMARCO, Cândido Rangel. "Capítulos de sentença", $4^{\mathrm{a}}$ ed., Malheiros, São Paulo, 2009, p.
} 61. 
como premissa lógica da questão principal. As matérias conhecidas, mas não decididas, são irrelevantes à configuração ou não da coisa julgada ${ }^{401}$.

Nessa linha, em relação à possibilidade de cisão do exame de causas de pedir ou de resistir, CÂNDIDO RANGEL DiNAMARCO afirma que a eliminação de uma delas não prejudica a análise das demais, devendo o processo prosseguir em relação aos fundamentos não atingidos. O exemplo citado é o de uma ação coletiva proposta com fundamento em responsabilidade subjetiva, nos termos dos artigos 186 e 927, do Código Civil, e em responsabilidade objetiva, prevista no Código de Defesa do Consumidor. Excluído um destes fundamentos, deve o processo continuar pelo outro, visto que autonomamente suficiente a apoiar a procedência do pedido ${ }^{402}$.

Embora pareça, num primeiro momento, adequada a conclusão de que, afastada parcela das causas de pedir da demanda, o processo deva prosseguir quanto aos fundamentos não excluídos, não se mostra correto sequer permitir ao juiz que elimine ou reduza, no curso do processo, o cúmulo objetivo de fundamentos. Isto porque tal providência encontraria óbice nos artigos 458, II, e 459, do Código de Processo Civil, que estabelecem a necessidade de o juiz enfrentar a integralidade das questões de méritoreferentes a uma pretensão na fundamentação da sentença, não podendo cindir tal análise em diversas decisões ao longo do processo.

Nessa linha, as cisões do julgamento de mérito podem ocorrer em duas situações:

(i) em relação a parcelas do objeto do processo, decidindo o juiz acerca de uma das pretensões e determinando o prosseguimento do processo em relação ao restante;

(ii) no tocante a fundamentos da demanda ou da defesa, antecipando-se o julgamento de alguma questão de mérito suscitada pelas partes, sem, contudo, definir a parcela do objeto do processo a ela correspondente.

\footnotetext{
${ }^{401}$ Cfr. BEDAQUE, José Roberto dos Santos. "Os elementos objetivos da demanda examinados à luz do contraditório", in CRUZ E TUCCI, José Rogério (coord.); BEDAQUE José Roberto dos Santos (coord.). "Causa de pedir e pedido no processo civil (questões polêmicas)", RT, São Paulo, 2002, p. 27.

${ }^{402}$ Cfr. DINAMARCO, Cândido Rangel. "Instituições de Direito Processual Civil", v. II, $6^{\mathrm{a}}$ ed., Malheiros, São Paulo, 2009, p. 193.
} 
Note-se que o próprio DinAMARCO apenas admite a primeira hipótese como espécie de cisão do exame de mérito válida à luz do sistema processual civil brasileiro, considerando, ainda, tal decisão como sentença parcial $^{403}$.

Por sua vez, a segunda situação encontraria óbice no princípio da unidade estrutural da sentença, previsto expressamente no CPC: todas as questões de mérito devem ser analisadas na fundamentação da sentença (art. 458, II), no mesmo momento em que o magistrado define a procedência ou a improcedência da demanda (art. 459) $)^{404}$.

Não se trata, contudo, de fenômeno novo. Na verdade, ocorria com certa frequiência, mesmo antes do advento da Lei n. 11.232/05 $5^{405}$.

Ainda quanto à cumulação de causas de pedir, há na doutrina quem identifique utilidade na decisão do juiz que a extingue ou reduz. Afirmase que daí poderiam ser extraídas consequências úteis e importantes aos sujeitos processuais, de modo que seria dever do juiz afastar, de forma diferida, fundamentos da demanda que se mostrassem inverídicos. O exemplo invocado é o da ação de despejo, fundada na falta de pagamento e no desvio de finalidade na utilização do imóvel. Verificando que o pagamento dos aluguéis encontra-se em dia, o magistrado deveria cindir o julgamento do mérito, definindo, desde logo, tal situação. Isto porque não se poderia pensar "que essa antecipação na resolução da demanda não tenha nenhuma utilidade ao réu, muito pelo contrário, servirá, sobretudo, como prova de que, não

\footnotetext{
${ }^{403}$ Vale transcrever o excerto: "O sistema processual civil brasileiro comporta aquela primeira espécie de cisão, sendo dever do juiz excluir desde logo do objeto do processo eventuais pretensões insuscetíveis de julgamento de mérito (um pedido juridicamente impossível, ilegitimidade ad causam do autor ou do réu em relação a um dos pedidos etc.), ou mesmo, em alguns casos, julgá-las pelo próprio mérito (prescrição, decadência). Em todos esses casos o processo prosseguirá pelo pedido que restar, mas a teor da conceituação emergente do art. 162, $\S 1^{\circ}$, do Código de Processo Civil, esse julgamento parcial será conceituado como sentença" (cfr. "Instituições de direito processual civil", v. III, $6^{\mathrm{a}}$ ed., Malheiros, São Paulo, 2009, p. 700).

${ }^{404}$ Cfr. DINAMARCO, Cândido Rangel. "Instituições de direito processual civil", v. III, $6^{\mathrm{a}}$ ed., Malheiros, São Paulo, 2009, p. 701.

${ }^{405}$ Nesse sentido, afirma PAULO HENRIQUE DOS SANTOS LUCON que "isso já ocorria no regime anterior, quando o juiz, no curso do processo, afastava a alegação de prescrição e decadência, cindindo a decisão de mérito" (cfr. "Sentença e liquidação no CPC (Lei n. 11.232/2005)", disponível em http://novo.direitoprocessual.org.br/fileManager/Paulo_Lucon__Sentena_e_liquidao_no_CPC.doc, acessado em 6.6.11, pp. 7-8).
} 
obstante sofra uma cobrança judicial, foi reconhecida sua adimplência por sentença" ${ }^{\text {406. }}$.

Não obstante louvável a preocupação com a celeridade e a efetividade do processo demonstrada por tal posicionamento, não é possível com ele concordar. Isto porque, conforme já afirmado, o juiz não pode cindir o julgamento de questões de mérito, sem que, ao fazê-lo, julgue, também, a pretensão a que nelas encontra solução. Ora, se a pertinência ou impertinência de um dos fundamentos da demanda encontra-se devidamente demonstrada, e a parte tem interesse que o juiz sobre ele decida de forma autônoma, deverá ajuizar ação declaratória incidental.

Através da referida demanda incidental, aquele ponto que antes constituía mera questão de mérito, integrante do objeto de cognição do juiz, passará a fazer parte do objeto litigioso do processo. Dessa forma, poderá o juiz pronunciar sobre a questão em decisão com aptidão a adquirir a qualidade de coisa julgada material. Contudo, sem que seja ajuizada a ação de declaração incidental, a decisão do magistrado que analisa apenas um dos fundamentos da demanda é nula, por afronta ao art. 458, II, e 459, do Código de Processo Civil.

A desacumulação de demandas, por meio de sentença parcial de mérito, é ferramenta destinada à redução do objeto litigioso do processo, seja ele complexo ou decomponível. O simples fato de a acumulação de fundamentos não trazer qualquer reflexo na complexidade - e nem na decomponibilidade - do objeto litigioso do processo já é indício de que o fracionamento de sua análise - além de violar regras do Código - não traz qualquer resultado prático útil ao processo. Ora, a decisão que afasta um dos fundamentos da demanda ou da defesa, sem julgar a pretensão a ele correspondente, não tem o condão de satisfazer ou de rejeitar o pedido, quer o mediato, quer o imediato: o litígio permanece vivo.

Diante disso, é possível concluir que a autorização de prolação de sentenças parciais, trazida pela Lei n. 11.232/05, não alcança o

\footnotetext{
${ }^{406}$ Cfr. SOUZA JUNIOR, Sidney Pereira de. "Sentenças parciais no processo civil - consequências no âmbito recursal”, Método, São Paulo, 2009, pp. 95-96.
} 
proferimento de decisões interlocutórias que examinem apenas questões de mérito, sem implicar qualquer das hipóteses previstas no art. 269, do CPC.

Dessa forma, pode o magistrado reconhecer a existência de prescrição ou decadência em relação a um dos pedidos formulados, proferindo sentença parcial de mérito, nos termos dos artigos 162, § $1^{\circ}$, c.c. 269 , IV, do Código. Entretanto, não deverá assim proceder para rejeitar eventual alegação de prescrição ou decadência referente a um dos pedidos formulados sem que o julgue, na mesma decisão, já que tal hipótese não se enquadra no art. 269, de modo que não se estaria diante de sentença parcial, mas, sim, de decisão interlocutória (art. 162, $\left.\S 2^{\circ}\right)^{407}$.

A sede adequada para a resolução de questões de mérito não são as decisões interlocutórias, mas sim a parte da fundamentação da sentença, nos termos dos artigos 458 e 469, do Código. Inviável, portanto, a cisão do exame do mérito nessa última hipótese.

A resolução de questões de mérito fora da sentença afronta, ainda, os artigos $5^{\circ}$ e 325 do Código de Processo Civil, os quais reservam para a sentença a resolução de questões prejudiciais de mérito. Há, assim, verdadeira reserva do julgamento do mérito para as sentenças, sejam parciais ou finais ${ }^{408}$.

Nesse sentido, a cisão do julgamento de questões de mérito produz decisão reputada como nula pela doutrina ${ }^{409}$, a qual tem o condão de trazer graves e indesejadas consequências ao sistema, visto prevalecer o entendimento pela sua aptidão à aquisição da qualidade de coisa julgada material ${ }^{410}$.

Pense-se na hipótese em que o juiz, ao sanear o processo, rejeita a alegação de prescrição, contra a qual o réu interpõe agravo de instrumento, sem

${ }^{407} \mathrm{Cfr}$. SICA, Heitor Vitor Mendonça. "Algumas implicações do novo conceito de sentença, de acordo com a Lei n. 11.232/2005", in CARMONA, Carlos Alberto (coord.). Reflexões sobre a reforma do Código de Processo Civil, Atlas, São Paulo, 2007, pp. 195-196.

${ }^{408}$ Cfr. SICA, Heitor Vitor Mendonça. "Preclusão processual civil", Atlas, São Paulo, 2006, pp. 195 e 202.

${ }^{409}$ Cfr. DINAMARCO, Cândido Rangel. "Instituições de direito processual civil", v. III, $6^{\mathbf{a}}$ ed., Malheiros, São Paulo, 2009, p. 702.

${ }^{410}$ Cfr. DINAMARCO, Cândido Rangel. "Nova era do processo civil", $1^{\mathrm{a}}$ ed., Malheiros, São Paulo, 2004, pp. 280-289. 
se discutir a irregularidade procedimental ocorrida. Negado provimento ao recurso, após regular dilação probatória, é proferida sentença de procedência do pedido formulado pelo autor, cujo resultado é mantido pelo Tribunal, ao julgar o recurso de apelação, transitando materialmente em julgado o respectivo acórdão.

Ao se imaginar eventual ação rescisória por infração às regras processuais referentes à rejeição da prescrição surge o seguinte impasse: (i) o acórdão que manteve o julgamento de primeiro grau não poderia ser alvo da impugnação por esse fundamento, já que sobre ele não se pronunciou; (ii) a decisão interlocutória que analisou a questão não poderia ser objeto de rescisória, visto que somente sentenças de mérito podem ser rescindidas (art. 485, caput, do CPC).

Diante disso, para resolver essa situação extraordinária, entende-se que o campo de cabimento da ação rescisória deve ser excepcionalmente ampliado, sob pena de denegação de acesso à Justiça ${ }^{411}$. Admitir-se-ia, portanto, o ajuizamento de rescisória contra interlocutórias de mérito.

Contudo essa posição não é isenta de críticas na doutrina. Há quem defenda que a referida decisão interlocutória não transitaria materialmente em julgado, justamente por força do art. 469, do CPC, o qual exclui do manto da coisa julgada material tanto a motivação da sentença (inciso I), quanto a apreciação incidental de questão prejudicial (inciso III).

Dessa forma, na situação acima desenhada, o ajuizamento da rescisória contra a interlocutória de mérito se mostraria inviável, por ausência de interesse de agir, já que, em relação a ela, não haveria coisa julgada material a ser rescindida.

No entanto, embora tal decisão seja insuscetível de adquirir imutabilidade, a referida questão prejudicial não poderia ser reapreciada em outros processos com o fim de transgredir o decisum transitado em julgado, tendo em

\footnotetext{
${ }^{411}$ Cfr. WAMBIER, Teresa Arruda Alvim. "Os agravos no CPC brasileiro", $4^{\mathrm{a}}$ ed., RT, São Paulo, 2006, p. 113; v. tb. DINAMARCO, Cândido Rangel. "Instituições de direito processual civil", v. III, $6^{\mathrm{a}}$ ed., Malheiros, São Paulo, 2009, p. 702.
} 
vista que a sentença de mérito, posteriormente proferida, traria consigo o efeito preclusivo da coisa julgada (art. 474, do Código).

Destarte, para evitar prejuízos à parte, deveria ser admitido o ajuizamento da rescisória contra ambas as decisões: a que cindiu o exame da questão de mérito e a que decidiu o mérito da demanda. Rescindir-se-ia o errôneo comando do decisum, pelo fundamento equivocadamente afastado na interlocutória ${ }^{412}$.

Trata-se de construção engenhosa, mas que acaba por incidir na mesma dificuldade apontada em relação à primeira solução: ao acrescentar a sentença proferida ao final ao objeto da rescisão, não elimina a necessidade de se atacar a decisão interlocutória de mérito pela via da ação rescisória.

Contudo, não parece necessário nem adequado rescindir, nem utilizar a decisão interlocutória viciada para resguardar os interesses do sujeito processual prejudicada. Isto porque os reflexos da indigitada decisão incidirão sobre a sentença a ser proferida e sobre esse ato devem ser concentrados os esforços da parte, para que seja corrigida a equivocada apreciação antecipada de questão de mérito incidental.

Destarte, é possível pensar em uma terceira saída. À luz dos artigos $162, \S \S 1^{\circ}$ e $2^{\circ}$, e 269 , ambos do CPC, embora a decisão do juiz que tenha por objetivo analisar apenas um dos fundamentos de mérito da demanda deva ser classificada como interlocutória, é possível verificar a existência de significativa semelhança entre esse provimento jurisdicional e a sentença maculada pela ausência de dispositivo.

Nas duas hipóteses examinam-se apenas questões de mérito trazidas ao conhecimento do magistrado, sem que esse profira qualquer decisão acerca do objeto do processo, remanescendo vivo o litígio, visto que não respondida a pretensão formulada pelo demandante.

${ }^{412}$ Cfr. SICA, Heitor Vitor Mendonça. "Preclusão processual civil”, Atlas, São Paulo, 2006, pp. 203-204. 
E, como se sabe, a doutrina atribui à sentença sem dispositivo o vício da inexistência ${ }^{413}$, pois a falta da parte decisória implica ausência de resolução do conflito deduzido perante o Poder Judiciário ${ }^{414}$. Tratar-se-ia de um arremedo que sequer poderia qualificar-se propriamente como sentença ${ }^{415}$, não sendo apto ao trânsito em julgado ou à imunização por preclusão ${ }^{416}$. Eventual questão decidida em decisão maculada por tal vício poderia ser rediscutida pelas partes em qualquer momento e grau de jurisdição.

Contudo, a doutrina aponta que as sentenças inexistentes devem ser declaradas como tal, para que deixem de produzir efeitos ${ }^{417}$. Ocorre que a sentença sem dispositivo não tem eficácia, já que desprovida de qualquer comando tendente à modificação da realidade: é ato inexistente, nulo e ineficaz. Desnecessário seria, portanto, o ajuizamento de qualquer ação declaratória autônoma visando a extirpar do mundo jurídico efeitos que não se operaram.

Diante da similitude entre as situações, é possível atribuirlhes as mesmas consequências jurídicas. A decisão interlocutória que soluciona incidentalmente questão de mérito seria juridicamenteinexistente, incapaz de gerar quaisquer efeitos. Além disso, não teria aptidão à aquisição da qualidade de coisa julgada, seja formal ou material, não podendo sequer ser alcançada pela preclusão ${ }^{418}$.

\footnotetext{
${ }^{413}$ Embora haja certa controvérsia acerca da categoria da inexistência no direito processual, o fato é que o Código a contempla de forma explícita, ao determinar serem inexistentes os atos praticados por advogado sem mandato (art. 37) (cfr. WAMBIER, Teresa Arruda Alvim. "Nulidades do processo e da sentença", $4^{\mathrm{a}}$ ed., RT, São Paulo, 1997, p. 230).

${ }^{414}$ Cfr. DINAMARCO, Cândido Rangel. "Instituições de direito processual civil", v. III, $6^{\mathrm{a}}$ ed., Malheiros, São Paulo, 2009, p. 713; v. tb. WAMBIER, Teresa Arruda Alvim. "Nulidades do processo e da sentença", $4^{\mathrm{a}}$ ed., RT, São Paulo, 1997, p. 354; BARBOSA MOREIRA, José Carlos. "Item do pedido sobre o qual não houve decisão. Possibilidade de reiteração noutro processo", in Temas de direito processual civil, $2^{\mathrm{a}}$ série, Saraiva, 1988, p. 241.

${ }^{415}$ Cfr. VIGLIAR, José Marcelo Menezes. "Pedido genérico e projeto de sentença", in CRUZ E TUCCI, José Rogério (coord.); BEDAQUE José Roberto dos Santos (coord.). "Causa de pedir e pedido no processo civil (questões polêmicas)", RT, São Paulo, 2002, p. 332.

${ }^{416}$ Cfr. WAMBIER, Teresa Arruda Alvim. "Os agravos no CPC brasileiro", $4^{\mathrm{a}}$ ed., RT, São Paulo, 2006, p. 489.

${ }^{417}$ Cfr. WAMBIER, Teresa Arruda Alvim. "Nulidades do processo e da sentença", $4^{\mathrm{a}}$ ed., RT, São Paulo, 1997, p. 232.

${ }^{418}$ Indo parcialmente ao encontro do que afirmado, HeITOR VITOR MENDONÇA SiCA sustenta que não haveria preclusão pro iudicato, visto que a referida cisão decorria de error in procedendo, consubstanciando-se, assim, em nulidade processual (cfr. "Preclusão processual civil", Atlas, São Paulo, 2006, p. 204).
} 
Assim, o magistrado pode edeve reexaminar a questão ao proferir sentença final, seja para retificar ou confirmar o quanto decidido em momento processual inoportuno. Se não o fizer haverá decidido, na sentença, questão prejudicada sem se manifestar sobre questão prejudicial, proferindo provimento jurisdicional em afronta aos artigos $2^{\circ}, 5^{\circ}, 325,458$, II e 459, do Código de Processo Civil.

Pela posição ora defendida, a decisão interlocutória que cinde o julgamento de questões de mérito é inexistente, enquanto a sentença subsequente, proferida sem o reexame do ponto analisado na referida interlocutória, é nula, pois não resolve integralmente a causa trazida a juízo (sentença citra petita).

De um lado, o primeiro provimento - inexistente - pode se sujeitar a controle jurisdicional pela via recursal ou não: tal insurgência, embora possível para fins de trazer a marcha processual de volta a seus regulares trilhos, é irrelevante, pois a questão decidida não gera eficácia extraprocessual, nem é objeto de preclusão, devendo ser obrigatoriamente reexaminada na sentença. De outro, caso o segundo provimento - citra petita-não seja consertado dentro do processo por meio de recurso de apelação, poderá ser atacado pela via da ação rescisória, dentro do prazo decadencial bienal.

Dessa forma, duas opções se abrem à parte prejudicada em relação à sentença que analisa a demanda sem reenfrentar a questão de mérito indevidamente antecipada:

(i) provocar o controle jurisdicional pela via recursal, sanando-o no âmbito da mesma relação jurídica processual;

(ii) ajuizar ação rescisória, no biênio decadencial, contra a sentença, sob o fundamento de essa ser citra petita, já que não analisado um dos fundamentos da demanda (ou da defesa) que mantém nítida relação de prejudicialidade com a questão principal, condicionando, assim, o resultado do julgamento do mérito. 


\subsection{ART. 273, $\$ 6^{\circ}:$ ANTECIPACÃO DE TUTELA OU JULGAMENTO ANTECIPADO?}

Até o advento da Lei n. 10.444/02, o sistema processual privilegiava de forma excessiva o princípio da unicidade da sentença em detrimento da efetividade processual.

Era curiosa a situação existente: caso o réu não contestasse a demanda, estaria configurada hipótese de julgamento antecipado da lide, nos termos do art. 330, do CPC; entretanto, se houvesse impugnação a apenas parcela dos pedidos formulados pelo autor, o juiz não estava autorizado a proferir nenhum pronunciamento sobre a parte incontrovertida, devendo o autor aguardar todo o trâmite processual para obter o bem da vida pleiteado.

Destarte, era irrelevante se o réu impugnasse todas as pretensões formuladas pelo autor ou apenas parte delas: o tempo de esperar era rigorosamente o mesmo. Com a introdução do $\S 6^{\circ}$ ao art. 273 essa situação foi mitigada, pois foi criada a possibilidade de o juiz conceder tutela antecipada em relação à parcela do objeto processual não controvertida pelo réu. Eliminou-se, assim, grande parte da angústia suportada pelo autor ${ }^{419}$.

Trata-se de técnica processual que potencializa as consequências do descumprimento do ônus da impugnação específica (art. 302, do $\mathrm{CPC})^{420}$, sendo capaz de incentivar o réu a contestar a demanda de forma mais diligente $^{421}$ e de melhor assegurar os interesses do autor, na hipótese de incontrovérsia parcial.

\footnotetext{
${ }^{419}$ Cfr. BONÍCIO, Marcelo José Magalhães. "Notas sobre a tutela antecipada 'parcial' na nova reforma do Código de Processo Civil", in Revista dos Tribunais, n. 808, fevereiro de 2003, p. 78-79.

${ }^{420} \mathrm{Cfr}$. BONÍCIO, Marcelo José Magalhães. "Notas sobre a tutela antecipada 'parcial' na nova reforma do Código de Processo Civil", in Revista dos Tribunais, n. 808, fevereiro de 2003, p. 73.

${ }^{421}$ Cfr. LUCON, Paulo Henrique dos Santos. "Estabilização da tutela antecipada e julgamento parcial do mérito", disponível

em http://direitoprocessual.org.br/fileManager/Paulo_Lucon_Estabilizao_da_tutela_antecipada_e_julgame nto_parcial_do_mrito.doc, acessado em 10.1.12, pp. 15-16.
} 
A "tutela antecipada" é mecanismo de reequilíbrio na distribuição do tempo no processo. Não é justo que o autor tenha que aguardar o decurso do processo de conhecimento para obter bem da vida cuja pretensão não foi resistida pelo réu. Assim, não se trata de técnica de tutela de urgência ou cautelar, nem punitiva, mas sim de tutela da evidência, de modo a não prejudicar o autor que tem razão com uma demora desnecessária na satisfação de seu direito ${ }^{422}$.

Diferentemente dos demais casos de antecipação dos efeitos da tutela, em que se estabelece conflito entre os princípios da segurança jurídica e da efetividade do processo, no caso do art. $273, \S 6^{\circ}$, não há tal colisão, existindo simples "ação afirmativa em benefício do princípio constitucional da efetividade" 423 , diante da incontrovérsia existente.

O grande idealizador da tutela do incontroverso foi LUIZ GUILHERME MARINONI que defendeu, em clássica obra, a possibilidade de antecipação da própria tutela - e não somente de seus efeitos ${ }^{424}$. A adoção de sua sugestão pelo legislador contou expressamente da exposição de motivos do Projeto de Lei n. 3.476, que deu origem à Lei n. 10.444/02 225 .

Todavia, a possibilidade de antecipação de tutela em relação a parte do pedido ou dos pedidos que se tornasse incontroversafoi inserida em nosso ordenamento no $\S 6^{\circ}$ do art. 273 , o qual é destinado a regular a antecipação dos efeitos da tutela a ser concedida.

Assim, embora se trate de instituto que trabalha com situação de incontrovérsia processual, a forma como foi concebido pelo legislador fez nascer significativa controvérsia doutrinária acerca de sua natureza jurídica.

\footnotetext{
${ }^{422}$ Cfr. VAZ, Paulo Afonso Brum. "Tutela antecipada fundada na técnica da ausência de controvérsia sobre o pedido ( $\$ 6^{\circ}$ do art. 273 do CPC)", in Revista de Processo, n. 131, pp. 128-129.

${ }^{423}$ Cfr. ZAVASCKI, Teori Albino. "Antecipação da tutela em face de pedido incontroverso", in Revista Jurídica, n. 301, novembro de 2002, p. 31.

${ }^{424} \mathrm{Cfr}$. MARINONI, Luiz Guilherme. "Tutela antecipatória e julgamento antecipado: parte incontroversa da demanda", $5^{\mathrm{a}}$ ed., RT, São Paulo, 2002.

${ }^{425}$ Cfr. ARAÚJO, José Henrique Mouta. "Tutela antecipada do pedido incontroverso: estamos preparados para a nova sistemática processual?”, in Revista de Processo, n. 116, p. 212.
} 
De um lado, MARINONI indica que a indigitada técnica seria semelhante ao art. 277, 2, do Codicediproceduracivile ${ }^{426}$. De acordo com a regra processual italiana, "oCollegio, a apreciar o mérito, deve decidir, em princípio, todas as demandas cumuladas, exaurindo a matéria a ser decidida. Contudo, assegura-se ao Collegio a possibilidade de limitar a decisão a algumas demandas, no caso em que se reconhece que somente para estas não é necessária uma ulterior instrução, e se a sua pronta definição é de interesse relevante para a parte que a requereu" "427. Destarte, tratar-se-ia de decisão dotada de definitividade, visto que fundada em cognição exauriente, ou seja, estar-se-ia diante de julgamento antecipado de parcela da demanda.

De outro lado, há quem identifique semelhança entre o art. $273, \S 6^{\circ}$, do CPC, e o art. 186-bis, do CPC italiano ${ }^{428}$. Para essa corrente, tratar-se-ia de hipótese de antecipação de efeitos práticos da tutela, concedida por meio de decisão provisória, proferida à luz de cognição sumária ${ }^{429}$, à semelhança das demais hipóteses previstas no próprio art. 273.

Entretanto, a demonstrar a complexidade do tema, a própria doutrina italiana se divide acerca da natureza jurídica da tutela concedida nesse dispositivo.

\footnotetext{
426“'Art. 277. (Pronuncia sul merito)

[....].
}

Tuttavia il collegio, anche quando il giudice istruttore gli ha rimesso la causa a norma dell'articolo 187 primo comma, può limitare la decisione ad alcune domande, se riconosce che per esse soltanto non sia necessaria un'ulteriore istruzione, e se la loro sollecita definizione è di interesse apprezzabile per la parte che ne ha fatto istanza".

${ }^{427} \mathrm{Cfr}$. MARINONI, Luiz Guilherme. "Tutela antecipatória e julgamento antecipado: parte incontroversa da demanda", $5^{\text {a }}$ ed., RT, São Paulo, 2002, p. 142.

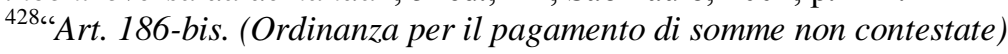

Su istanza di parte il giudice istruttore può disporre, fino al momento della precisazione delle conclusioni, il pagamento delle somme non contestate dalle parti costituite. Se l'istanza è proposta fuori dall'udienza il giudice dispone la comparizione delle parti ed assegna il termine per la notificazione. processo.

L'ordinanza costituisce titolo esecutivo e conserva la sua efficacia in caso di estinzione del

L'ordinanza è soggetta alla disciplina delle ordinanze revocabili di cui agli articoli 177, primo e secondo comma, e 178, primo comma".

${ }^{429}$ Cr. BARBOSA MOREIRA, José Carlos. "Tutela de urgência e efetividade do direito", in Temas de direito processual, $8^{\mathrm{a}}$ série, Saraiva, São Paulo, 2004, p. 102; v. tb. BEDAQUE, José Roberto dos Santos. "Tutela cautelar e tutela antecipada: tutelas sumárias e de urgência (tentativa de sistematização)", $5^{\mathrm{a}}$ ed., Malheiros, São Paulo, 2009, pp. 362-363; BONÍCIO, Marcelo José Magalhães. "Notas sobre a tutela antecipada 'parcial' na nova reforma do Código de Processo Civil", in Revista dos Tribunais, n. 808, fevereiro de 2003, p. 73. 
Parcela da doutrina entende que, não obstante o legislador tenha atribuído o nome de ordinanza a essa decisão, trata-se, na verdade, de um provimento fundado em cognição plena ${ }^{430}$. Contudo, outra parte dos processualistas considera o provimento como mera antecipação dos efeitos da sentença final ${ }^{431}$.

Não obstante atribuir-se naturezas jurídicas flagrantemente díspares ao instituto, a controvérsia existente se explica, na medida em que ambas encontram fundamentos comuns: (i) inexiste razão ou princípio moral, ético ou jurídico que justifique o descumprimento de obrigações incontroversas; (ii) o processo não pode ser ferramenta de abuso de direito, pois é meio de realização do direito material e não expediente de procrastinação de seu cumprimento ${ }^{432}$.

De todo modo, afirma-se, em uníssono, que quanto menor for a controvérsia, menor tempo deve ser necessário para que o processo termine. Não há razão para se impor às partes o ônus de esperar o mesmo intervalo de tempo para o julgamento de pretensões controversas e incontroversas ${ }^{433}$.

Pois bem. Há, na doutrina pátria, três correntes acerca da natureza jurídica da decisão proferida com fulcro no art. 273, § $6^{\circ}$, do Código:

(i) Trata-se de decisão fundada em cognição exauriente, dotada de definitividade e apta a adquirir a coisa julgada material. Seria hipótese de

\footnotetext{
${ }^{430}$ Nesse sentifo, afirma ANDREA PROTO PISANI: "L'ordinanza (di pagamento ovvero di consegna o rilascio) è emanata dal giudice istruttore <nei limiti in cui ritiene già raggiunta la prova>. Nonostante il carattere non felice dell'espressione la dottrina è assolutamente concorde nel ritenere cha l'ordinanza, perchè emanabile solo a istruzione esaurita, è um provvedimento a cognizione piena. La formula sopra riportata sarebbe tata utilizzata dal legislatore non per richiamare ad una inesistente dell'acertamento, bensì solo per evidenziare che non l'ordinanza il giudice istruttore poù irtenere anche solo parzialmente fondata la domanda" (cfr. "Lezioni di diritto processuale civile", $4^{\mathrm{a}}$ ed. Napoli: Juvene, 2002, p. 624).

${ }^{431}$ É a lição de Michele Tarufo, Luigi PaOlo Gomoglio e ConRAdo FerRi: "Ora, gli artt. 186 bis, 186 ter e 186 quarter c.p.c. disciplinano atti giudiziali inquadrabili nella categoria sistematica dei c.d. provvedimenti anticipatori e interinali di condanna, la cui specifica funzione - entro il genus degli accertamenti con prevalente funzione esecutiva - è quella di anticipare, in determinati momenti che precedono la definizione del giudizio di primo grado, il soddisfacimento del diritto controverso e gli effetti esecutivi della sentenza finale" (cfr. "Lezioni sul processo civile", $2^{\mathrm{a}}$ ed., Bologna: Mulino, 1995, p. 684).

${ }^{432}$ Cfr. WAMBIER, Luiz Rodrigues. "Considerações sobre a parte incontroversa da demanda na ação movida pelo devedor: os arts. 49 e 50 da Lei 10.391/2004", in Revista de Processo, n. 143, pp. 31-32.

${ }^{433}$ Cfr. DORIA, Rogéria Dotti. "A tutela antecipada em relação à parte incontroversa da demanda”, RT, São Paulo, 2004, p. 80.
} 
fracionamento do julgamento do mérito, seja por decisão interlocutória ou por sentença $\operatorname{parcial}^{434}$.

(ii) Trata-se de decisão fundada em cognição exauriente, mas que não é dotada de definitividade, nem é capaz de transitar materialmente em julgado, visto que o ordenamento brasileiro veda a cisão do julgamento de mérito. Seria hipótese excepcional de concessão de antecipação dos efeitos práticos da tutela, fundada em cognição plena ${ }^{435}$.

(iii) Trata-se de decisão fundada em cognição sumária, provisória, revogável e insuscetível de transitar materialmente em julgado, como

\footnotetext{
${ }^{434}$ Cfr. SICA, Heitor Vitor Mendonça. "Preclusão processual civil", Atlas, São Paulo, 2006, p. 205; v. tb. THEODORO JR., Humberto. As novas reformas do Código de Processo Civil, $2^{\mathrm{a}}$ ed., Forense, Rio de Janeiro, 2007, p. 45; MITIDIERO, Daniel. "Direito fundamental ao julgamento definitivo da parcela incontroversa: uma proposta de compreensão do art. $273, \S 6^{\circ}$, CPC, na perspectiva do direito fundamental a um processo sem dilações indevidas (art. $5^{\circ}$, LXXVIII, CF/88)", in Revista de Processo, $\mathrm{n}$. 149, pp. 111-112; AYOUB, Luiz Roberto; PELLEGRINO, Antônio Pedro. "A sentença parcial", in Revista de Arbitragem e Mediação, n. 22, RT, São Paulo, jul.-set./2009, p. 45; ARAÚJO, José Henrique Mouta. "Tutela antecipada do pedido incontroverso: estamos preparados para a nova sistemática processual?", in Revista de Processo, n. 116, pp. 213-216; DALL'ALBA, Felipe Camilo. “Julgamento antecipado ou antecipação dos efeitos da tutela do pedido incontroverso?", in Revista de Processo, $\mathrm{n}$. 128, p. 221; SANT'ANNA, Paulo Afonso de Souza. "Sentença parcial", in MEDINA, José Miguel Garcia (coord.); CRUZ, Luana Pedrosa de Figueiredo (coord.); CERQUEIRA, Luís Otávio Sequeira de (coord.); Junior, Luiz Manoel Gomes (coord). "Os poderes do juiz e o controle das decisões judiciais", RT, São Paulo, 2008, p. 452; CASSOL, Maria Helena. "Perspectivas atuais da tutela antecipada e a quebra do princípio da unicidade da sentença", in Revista da AJURIS, n. 111, AJURIS, Rio Grande do Sul, setembro de 2008, p. 173; DIDIER JUNIOR, Fredie. "Inovações na antecipação dos efeitos da tutela e a resolução parcial do mérito", in Revista de Processo n. 110, RT, São Paulo, abril-junho de 2003, pp. 233-234; OLIANI, José Alexandre Manzano. "Cumprimento da sentença interlocutória que condena ao pagamento de soma, de acordo com a Lei 11.232/05", in SANTOS, Ernane Fidélis (coord.); WAMBIER, Luiz Rodrigues (coord.); NERY JR., Nelson (coord.); WAMBIER, Teresa Arruda Alvim (coord.). Execução civil: estudos em homenagem ao professor Humberto Theodoro Júnior, RT, São Paulo, 2007, p. 181; SILVA FILHO, Ricardo de Oliveira. "A sentença parcial de mérito e o processo civil moderno", in Revista da AJURIS, n. 108, AJURIS, Porto Alegre, dezembro de 2007, pp. 286-287; SOUZA JUNIOR, Sidney Pereira de. "Sentenças parciais no processo civil - consequências no âmbito recursal", Método, São Paulo, 2009, p. 104; JORGE, Flávio Cheim; RODRIGUES, Marcelo Abelha; DIDIER JUNIOR.,Fredie. "A nova reforma processual", $2^{\mathrm{a}}$ ed. Saraiva, 2003, São Paulo, p. 72.

${ }^{435}$ Cfr. DINAMARCO, Cândido Rangel. "A reforma da reforma", Malheiros, São Paulo, 2002, pp.95-96 e 100-102; v. tb. LUCON, Paulo Henrique dos Santos. "Estabilização da tutela antecipada e julgamento parcial do mérito", disponível em http://direitoprocessual.org.br/fileManager/Paulo_Lucon_Estabilizao_da_tutela_antecipada_e_julgame nto_parcial_do_mrito.doc, acessado em 10.1.12, pp. 17 e 25; BONÍCIO, Marcelo José Magalhães. "Notas sobre a tutela antecipada 'parcial' na nova reforma do Código de Processo Civil", in Revista dos Tribunais, n. 808, fevereiro de 2003, p. 77; TERRA, Rogério Luiz dos Santos. "A antecipação de tutela do pedido incontroverso: questões polêmicas derivadas do art. 273, $\S 6^{\circ}$, do Código de Processo Civil", in Revista Forense, vol. 412, p. 258; DORIA, Rogéria Dotti. "A tutela antecipada em relação à parte incontroversa da demanda", RT, São Paulo, 2004, p. 117; LOPES, João Batista. "Tutela antecipada no processo civil brasileiro", RT, São Paulo, $3^{\mathrm{a}}$ ed., 2007, pp. 176-178; LUCCA, Rodrigo Ramina de. "Antecipação de tutela da parcela incontroversa do mérito e o conceito de sentença", disponível em http://www.abdpc.org.br/abdpc/artigos/Rodrigo\%20Ramina\%20de\%20Lucca.pdf, acessado em 28.6.11, p. 8 .
} 
qualquer outra modalidade de antecipação dos efeitos da tutela, obedecendo às regras processuais gerais pertinentes à categoria ${ }^{436}$.

Considera-se prevalecer na doutrina o primeiro entendimento, segundo o qual o provimento proferido com base no art. $273, \S 6^{\circ}$, do CPC, é uma decisão definitiva de mérito, apta ao trânsito em julgado material ${ }^{437}$.

Não há dúvidas de que, na antecipação de tutela, efeitos práticos do provimento futuro é que são antecipados e não a própria tutela, sendo fundada em cognição sumária a decisão que a concede ${ }^{438}$. Entretanto, para essa primeira corrente, a reforma trazida pela Lei n. 10.444/02, apesar de não expressamente o consignar, introduzira verdadeira hipótese de cisão do exame do mérito, não se tratando de mera antecipação de efeitos sociais de pronunciamento ulterior, visto que a decisão proferida seria fundada em cognição exauriente ${ }^{439}$.

A antecipação em tela não seria baseada em urgência, nem em juízo de probabilidade $e^{440}$. Isto porque a parcela do objeto processual incontroversa estaria madura para julgamento, não sendo necessária a produção de outras provas ${ }^{441}$. Não haveria se falar, portanto, em cognição sumária.

\footnotetext{
${ }^{436}$ Cfr. BEDAQUE, José Roberto dos Santos. "Tutela cautelar e tutela antecipada: tutelas sumárias e de urgência (tentativa de sistematização)", $5^{\text {a }}$ ed., Malheiros, São Paulo, 2009, p. 361; v. tb. CARNEIRO, Athos Gusmão. "Da antecipação de tutela", Forense, Rio de Janeiro, 2002, p. 60; VAZ, Paulo Afonso Brum. "Tutela antecipada fundada na técnica da ausência de controvérsia sobre o pedido ( $\$ 6^{\circ}$ do art. 273 do CPC)", in Revista de Processo, n. 131, pp. 139 e 141; NOTARIANO JUNIOR, Antonio; BRUSCHI, Gilberto Gomes. "O julgamento antecipado da lide e a antecipação de tutela em caso de pedidos incontroversos", in ARMELIN, Donaldo (coord.). "Tutelas de urgência e cautelares: estudos em homenagem a Ovídio A. Baptista da Silva", Saraiva, São Paulo, 2010, pp. 133-134; RIBEIRO, Darci Guimarães. "A garantia constitucional do contraditório e as presunções contidas no $\S 6^{\circ}$ do art. 273 do $C P C$ ", in ARMELIN, Donaldo (coord.). "Tutelas de urgência e cautelares: estudos em homenagem a Ovídio Araújo Baptista da Silva”, Saraiva, São Paulo, 2010, p. 356.

${ }^{437}$ Cfr. WAMBIER, Teresa Arruda Alvim. "O agravo e o conceito de sentença", in Revista de Processo, n. 144, RT, São Paulo, fevereiro de 2007, p. 251.

${ }^{438}$ Cfr. ARAÚJO, José Henrique Mouta. "Tutela antecipada do pedido incontroverso: estamos preparados para a nova sistemática processual?", in Revista de Processo, n. 116, p. 215.

439 Cfr. ARAÚJO, José Henrique Mouta. "Tutela antecipada do pedido incontroverso: estamos preparados para a nova sistemática processual?", in Revista de Processo, n. 116, p. 213.

${ }^{440}$ Cfr. ARAÚJO, José Henrique Mouta. "Coisa julgada progressiva \& resolução parcial do mérito", Juruá, Curitiba, 2008, p. 324.

${ }^{441}$ Cfr. SANT'ANNA, Paulo Afonso de Souza. "Sentença parcial", in MEDINA, José Miguel Garcia (coord.); CRUZ, Luana Pedrosa de Figueiredo (coord.); CERQUEIRA, Luís Otávio Sequeira de (coord.); Junior, Luiz Manoel Gomes (coord). "Os poderes do juiz e o controle das decisões judiciais", RT, São Paulo, 2008, p. 452.
} 
Nessa linha de raciocínio, seria equívoco considerar sumária a cognição somente em razão de a decisão sobre a parte incontroversa do objeto processual ser proferida em momento anterior ao julgamento do restante da demanda. A cognição seria exauriente, pois fundada na totalidade de provas necessárias ao julgamento daquela parcela do mérito ${ }^{442}$.

Dessa forma, o art. $273, \S 6^{\circ}$, do $\mathrm{CPC}$, conteria uma sentença camuflada de tutela antecipada, pois, havendo incontrovérsia, o exame realizado pelo magistrado seria baseado em juízo de cognição plena, não havendo se falar em verossimilhança ou em probabilidade ${ }^{443}$.

Sendo assim, a decisão que a concede teria aptidão a adquirir a qualidade de coisa julgada material ${ }^{444}$, de modo que o juiz não poderia confirmá-la, modificá-la ou revogá-la em decisão posterior ${ }^{445}$, limitando-se a apreciar a parcela do objeto processual ainda não julgada ${ }^{446}$.

Ademais, a interpretação do art. $273, \S 6^{\circ}$, do CPC, à luz do direito fundamental à razoável duração do processo (art. 5º LXXVIII, da CF), levaria à conclusão de que não se trata de mera antecipação dos efeitos da sentença final, mas de verdadeiro julgamento de mérito antecipado da parcela não controvertida da demanda ${ }^{447}$.

\footnotetext{
${ }^{442}$ Cfr. SANT'ANNA, Paulo Afonso de Souza. "Sentença parcial", in MEDINA, José Miguel Garcia (coord.); CRUZ, Luana Pedrosa de Figueiredo (coord.); CERQUEIRA, Luís Otávio Sequeira de (coord.); Junior, Luiz Manoel Gomes (coord). "Os poderes do juiz e o controle das decisões judiciais", RT, São Paulo, 2008, p. 452.

${ }^{443}$ Cfr. THEODORO JUNIOR, Humberto. As novas reformas do Código de Processo Civil, $2^{\mathrm{a}}$ ed., Forense, Rio de Janeiro, 2007, p. 45; v. tb. AYOUB, Luiz Roberto; PELLEGRINO, Antônio Pedro. "A sentença parcial", in Revista de Arbitragem e Mediação, n. 22, RT, São Paulo, jul.-set./2009, p. 45.

${ }^{444}$ Cfr. ARAÚJO, José Henrique Mouta. "Tutela antecipada do pedido incontroverso: estamos preparados para a nova sistemática processual?", in Revista de Processo, n. 116, p. 216.

${ }^{445} \mathrm{Cfr}$. SOUZA JUNIOR, Sidney Pereira de. "Sentenças parciais no processo civil - consequências no âmbito recursal", Método, São Paulo, 2009, p. 107.

${ }^{446} \mathrm{Cfr}$; JORGE, Flávio Cheim; RODRIGUES, Marcelo Abelha; DIDIER JUNIOR.,Fredie. "A nova reforma processual", $2^{\mathrm{a}}$ ed. Saraiva, 2003, São Paulo, p. 72.

${ }^{447} \mathrm{Cfr}$. MITIDIERO, Daniel. "Direito fundamental ao julgamento definitivo da parcela incontroversa: uma proposta de compreensão do art. $273, \S 6^{\circ}, C P C$, na perspectiva do direito fundamental a um processo sem dilações indevidas (art. $5^{\circ}$, LXXVIII, CF/88)", in Revista de Processo, n. 149, pp. 111-112.
} 
Nesse sentido, após a entrada em vigor da Lei n. 11.232/2005, parte da doutrina passou a considerar que o art. $273, \S 6^{\circ}$ realmente representa hipótese de julgamento parcial de mérito ${ }^{448}$.

Antes da alteração do conceito de sentença, o grande argumento para classificar a tutela do incontroverso como antecipação de efeitos práticos era a circunstância de a lei determinar que o mérito somente poderia ser definido por meio de sentença, sendo essa o único provimento judicial apto a transitar materialmente em julgado (artigos 459 e 467, do CPC). Contudo, com a última reforma processual, o princípio da unicidade da sentença foi quebrado, de modo que as hipóteses de incontrovérsia parcial do objeto do processo possibilitariam a prolação de sentença parcial de mérito, sendo essa a natureza da técnica processual introduzida pela Lei n. $10.444 / 02^{449}$.

Dessa forma, tratar-se-ia de pronunciamento judicial fundado em cognição exauriente ${ }^{450}$, visto que desnecessária a produção de qualquer outra prova para sua prolação ${ }^{451}$. Haveria, portanto, verdadeiro julgamento fracionado antecipado $^{452}$, com decisão apta a decidir definitivamente o litígio ${ }^{453}$ e a transitar materialmente em julgado ${ }^{454}$.

Como exemplo e reforço argumentativo, comparam-se as situações de ausência total e parcial de contestação. Se há cumulação de pedidos e um deles resta incontrovertido, porque não contrariado na resposta ofertada pelo réu,

\footnotetext{
${ }^{448}$ Cfr. SICA, Heitor Vitor Mendonça. "Algumas implicações do novo conceito de sentença, de acordo com a Lei n. 11.232/2005", in CARMONA, Carlos Alberto (coord.). Reflexões sobre a reforma do Código de Processo Civil, Atlas, São Paulo, 2007, p. 194.

${ }^{449}$ Cfr. SICA, Heitor Vitor Mendonça. "Preclusão processual civil", Atlas, São Paulo, 2006, p. 205.

${ }^{450}$ Cfr. SILVA FILHO, Ricardo de Oliveira. "A sentença parcial de mérito e o processo civil moderno", in Revista da AJURIS, n. 108, AJURIS, Porto Alegre, dezembro de 2007, pp. 286-287.

${ }^{451}$ Cfr. OLIANI, José Alexandre Manzano. "Cumprimento da sentença interlocutória que condena ao pagamento de soma, de acordo com a Lei 11.232/05", in SANTOS, Ernane Fidélis (coord.); WAMBIER, Luiz Rodrigues (coord.); NERY JR., Nelson (coord.); WAMBIER, Teresa Arruda Alvim (coord.). Execução civil: estudos em homenagem ao professor Humberto Theodoro Júnior, RT, São Paulo, 2007, p. 181.

${ }^{452}$ Cfr. CASSOL, Maria Helena. "Perspectivas atuais da tutela antecipada e a quebra do princípio da unicidade da sentença", in Revista da AJURIS, n. 111, AJURIS, Rio Grande do Sul, setembro de 2008, p. 173.

${ }^{453}$ Cfr. SOUZA JUNIOR, Sidney Pereira de. "Sentenças parciais no processo civil - consequências no âmbito recursal", Método, São Paulo, 2009, p. 104.

${ }^{454}$ Cfr. DALL'ALBA, Felipe Camilo. "Julgamento antecipado ou antecipação dos efeitos da tutela do pedido incontroverso?”, in Revista de Processo, n. 128, p. 221.
} 
haverá, em princípio, campo propício para a aplicação do art. $273, \S 6^{\circ}$, do CPC. Todavia, se as pretensões cumuladas fossem pleiteadas em processos distintos e esse mesmo pedido restasse igualmente incontrovertido, mas em razão da revelia do réu, configurar-se-ia hipótese de julgamento antecipado da lide (art. 330, II, do CPC) ${ }^{455}$, em decisão apta a resolver o litígio definitivamente.

Ora, se o réu não contestar ou não impugnar de forma específica a integralidade dos fatos, estar-se-á diante de incontrovérsia, situação que gera presunção de veracidade e autoriza o julgamento antecipado da lide (art. 330, II). Não haveria qualquer razão teórica ou prática a se obstar a aplicação dessa mesma conclusão ao caso de parcela dos pedidos restar incontroversa ${ }^{456}$, representando incongruência lógica a atribuição de efeitos jurídicos díspares a situações em tudo semelhantes.

Assim, se a incontrovérsia em relação à integralidade dos pedidos enseja o julgamento antecipado, capaz de produzir coisa julgada material, tal consequência deveria igualmente ocorrer na hipótese de apenas um ou parcela dos pedidos mostrar-se incontroversa. A hipótese de pedido incontroverso (art. 273, § $6^{\circ}$ ) encontrar-se-ia implicitamente contida nas de julgamento antecipado (art. 330) ${ }^{457}$.

Destarte, de acordo com essa primeira corrente, o legislador foi infeliz ao inserir a tutela do incontroverso entre as hipóteses previstas no art. 273, do Código ${ }^{458}$, pois não se trata de instrumento vocacionado a antecipar somente efeitos, mas, sim, a própria tutela ${ }^{459}$. Equivocada, portanto, a topologia dada $^{460}$, devendo a técnica ter sido introduzida no art. 330, do CPC, como hipótese de

\footnotetext{
${ }^{455}$ Cfr. ARAÚJO, José Henrique Mouta. "Coisa julgada progressiva \& resolução parcial do mérito", Juruá, Curitiba, 2008, p. 314.

${ }^{456}$ Cfr. ARAÚJO, José Henrique Mouta. "Coisa julgada progressiva \& resolução parcial do mérito", Juruá, Curitiba, 2008, p. 317.

${ }^{457}$ Cfr. ARAÚJO, José Henrique Mouta. "Coisa julgada progressiva \& resolução parcial do mérito", Juruá, Curitiba, 2008, p. 323.

${ }^{458}$ Cfr. AYOUB, Luiz Roberto; PELlEGRINO, Antônio Pedro. "A sentença parcial", in Revista de Arbitragem e Mediação, n. 22, RT, São Paulo, jul.-set./2009, p. 45.

${ }^{459}$ Cfr. AYOUB, Luiz Roberto; PELlEGRINO, Antônio Pedro. "A sentença parcial", in Revista de Arbitragem e Mediação, n. 22, RT, São Paulo, jul.-set./2009, p. 45.

${ }_{460}$ Cfr. SOUZA JUNIOR, Sidney Pereira de. "Sentenças parciais no processo civil - consequências no âmbito recursal”, Método, São Paulo, 2009, p. 106.
} 
julgamento antecipado de parcela da lide ${ }^{461}$, proferido com base em cognição exauriente e em decisão apta a transitar materialmente em julgado ${ }^{462}$.

Apesar de impressionarem, atualmente os argumentos não convencem. Dúvidas não há de que essa construção doutrinária foi muito importante no contexto em que desenvolvida, visto que possibilitou o início da discussão acerca da cindibilidade do exame do objeto do processo e da necessária mitigação do princípio da unicidade da sentença ${ }^{463}$. Através da então novel técnica introduzida, o legislador criou uma brecha que poderia ser explorada pelos operadores do direito a fim de conferir maior efetividade ao processo.

No entanto, com o advento da Lei n. 11.232/2005, houve o completo rompimento do dogma da unicidade do julgamento de mérito, sendo perfeitamente admissível sua cisão em sentenças parciais, proferidas no curso do procedimento, na medida em que as pretensões cumuladas (ou parcela da pretensão decomponível) amadurecerem.

Dessa forma, a incontrovérsia por ausência de contestação tornou-se apenas uma das hipóteses que, em tese, poderiam ensejar a prolação de sentença parcial de mérito, a qual, à luz do vigente ordenamento jurídico processual, teria por fundamento os artigos $162, \S 1^{\circ}$, e 330 , do Código de Processo Civil, sendo desnecessária qualquer remissão ao art. $273, \S 6^{\circ}$.

Destarte, a interpretação defendida por essa parcela da doutrina tornou-se, com a devida vênia, desnecessária. O contexto processual possibilita a prolação de sentenças parciais de mérito, bastando esteja a matéria madura para julgamento - independentemente de tal ter ocorrido por descumprimento do art. 302, do CPC, ou por outra razão, v.g., demonstração por prova documental ou reconhecimento

\footnotetext{
${ }^{461}$ Cfr. SILVA FILHO, Ricardo de Oliveira. "A sentença parcial de mérito e o processo civil moderno", in Revista da AJURIS, n. 108, AJURIS, Porto Alegre, dezembro de 2007, p. 293.

${ }^{462}$ Cfr. DIDIER JUNIOR, Fredie. "Inovações na antecipação dos efeitos da tutela e a resolução parcial do mérito", in Revista de Processo n. 110, RT, São Paulo, abril-junho de 2003, pp. 233-234.

${ }^{463}$ Cfr. SICA, Heitor Vitor Mendonça. "Algumas implicações do novo conceito de sentença, de acordo com a Lei n. 11.232/2005", in CARMONA, Carlos Alberto (coord.). Reflexões sobre a reforma do Código de Processo Civil, Atlas, São Paulo, 2007, p. 195; v. tb. BONÍCIO, Marcelo José Magalhães. "Notas sobre a tutela antecipada 'parcial' na nova reforma do Código de Processo Civil", in Revista dos Tribunais, n. 808, fevereiro de 2003, pp. 73-74.
} 
jurídico do pedido. Nesse sentido, é possível afirmar que a ampliação das hipóteses de cisão do julgamento de mérito por meio da prolação de sentenças parciais atende melhor ao direito fundamental à duração razoável do processo e torna desnecessário conferir interpretação ampliativa à técnica contida no art. $273, \S 6^{\circ}$, do CPC.

Além disso, defender que o art. 273, $\S 6^{\circ}$, do Código, encerra hipótese de julgamento parcial de mérito antecipado implica reconhecer sua revogação tácita pela última reforma processual havida. Ainda que se considere ter a Lei n. 10.444/02 inserido no sistema uma hipótese de cisão do exame do mérito, é imperioso admitir que a Lei n. 11.232/05 criou a possibilidade de fracionamento do julgamento do mérito sempre que tal medida se mostre viável. Assim, englobou a situação anteriormente prevista, cuidando integralmente da matéria, de modo a incidir o disposto no art. $2^{\circ}, \S 1^{\circ}$, da Lei de Introdução às normas do Direito Brasileiro ${ }^{464}$.

Entretanto, caso se considere que o art. $273, \S 6^{\circ}$, do Código, realmente é técnica de antecipação dos efeitos da tutela, é possível salvá-lo do ostracismo jurídico e dele extrair consequências práticas úteis, conforme se verá adiante.

No entanto, ainda entre os que defendem a natureza de antecipação de efeitos da tutela, diverge a doutrina.

A segunda corrente acima listada considera - à semelhança da primeira - que a decisão proferida com base no art. $273, \S 6^{\circ}$, do CPC, seria pronunciamento jurisdicional calcado em cognição exauriente, configurando situação ontologicamente idêntica àquela verificada no julgamento antecipado da demanda. Não remanesceria qualquer dúvida quanto à existência do direito material, no tocante à parcela do objeto processual incontroversa ${ }^{465}$.

\footnotetext{
464، Art. $2^{2}$ Não se destinando à vigência temporária, a lei terá vigor até que outra a modifique ou revogue.

$I^{\circ}$ A lei posterior revoga a anterior quando expressamente o declare, quando seja com ela incompatível ou quando regule inteiramente a matéria de que tratava a lei anterior.

[..]".

${ }^{465}$ Cfr. LUCON, Paulo Henrique dos Santos. "Estabilização da tutela antecipada e julgamento parcial do mérito", disponível

em http://direitoprocessual.org.br/fileManager/Paulo_Lucon__Estabilizao_da_tutela_antecipada_e_julgame nto_parcial_do_mrito.doc, acessado em 10.1.12, p. 17.
} 
Contudo, em razão de o sistema processual brasileiro - ao menos antes do advento da Lei n. 11.232/05 - não admitir o fracionamento do julgamento do mérito, a única solução aceitável seria considerar a técnica em tela como hipótese de mera antecipação dos efeitos da tutela ${ }^{466}$.

Destarte, tratar-se-ia de tutela antecipada fundada em cognição exauriente ${ }^{467}$, já que não seria possível a produção de qualquer outra prova até a prolação da sentença ${ }^{468}$. O único óbice a sua caracterização como julgamento antecipado seria o dogma da incindibilidade do exame do mérito ${ }^{469}$.

Esse o entendimento de CÂNDIDO RANGEl DinAmarco, divulgado em trabalho produzido antes do advento da Lei n. 11.232/2005: "ficando incontroverso apenas um ou alguns dos fatos constitutivos descritos nacausa petendi $e$ restando outros a provar, o sistema processual brasileiro repele o parcial julgamento do mérito ainda quando os fatos incontroversos (ou mesmo comprovados por documentos) sejam suficientes para fundamentar esse julgamento parcial. É para essa situação que o novo dispositivo autoriza a parcial antecipação da tutela jurisdicional forte na premissa de que, sendo incontroverso o fato, configura-se uma superlativa probabilidade de sua ocorrência, muito mais vigorosa que a exigida pelo art. 273 , caput" ${ }^{470}$.

\footnotetext{
${ }^{466}$ Cfr. BONÍCIO, Marcelo José Magalhães. "Notas sobre a tutela antecipada 'parcial' na nova reforma do Código de Processo Civil", in Revista dos Tribunais, n. 808, fevereiro de 2003, p. 77; v. tb. LUCON, Paulo Henrique dos Santos. "Estabilização da tutela antecipada e julgamento parcial do mérito", disponível em http://direitoprocessual.org.br/fileManager/Paulo_Lucon__Estabilizao_da_tutela_antecipada_e_julgame nto_parcial_do_mrito.doc, acessado em 10.1.12; TERRA, Rogério Luiz dos Santos. "A antecipação de tutela do pedido incontroverso: questões polêmicas derivadas do art. 273, $\S 6^{\circ}$, do Código de Processo Civil", in Revista Forense, vol. 412, p. 258.

${ }^{467}$ Cfr. LUCCA, Rodrigo Ramina de. "Antecipação de tutela da parcela incontroversa do mérito e o conceito de sentença", disponível em http://www.abdpc.org.br/abdpc/artigos/Rodrigo\%20Ramina\%20de\%20Lucca.pdf, acessado em 28.6.11, p. 8.

${ }^{468}$ Cfr. DORIA, Rogéria Dotti. "A tutela antecipada em relação à parte incontroversa da demanda”, RT, São Paulo, 2004, pp. 118-133.

${ }^{469}$ Cfr. DORIA, Rogéria Dotti. "A tutela antecipada em relação à parte incontroversa da demanda", RT, São Paulo, 2004, p. 117.

${ }^{470}$ Cfr. "A reforma da reforma", Malheiros, São Paulo, 2002, pp. 95-96.
} 
Dessa forma, diferentemente do sistema italiano, o brasileiro não admitiria o julgamento fracionado do mérito, trabalhando apenas com a possibilidade de antecipação dos efeitos da tutela, sempre em caráter provisório ${ }^{471}$.

Não se trataria, assim, de parcial julgamento antecipado do mérito, visto que, quando da entrada em vigor da Lei n. 10.444/02, ainda vigia com significativa força o dogma pelo qual o mérito deve ser julgado por apenas uma sentença no processo $^{472}$.

Nesse sentido, como as demais modalidades de tutela antecipada, a decisão acerca da parcela não controvertida do objeto litigioso do processo não possuiria o atributo da definitividade, devendo ser, necessariamente, confirmada, modificada ou revogada até o julgamento de mérito ${ }^{473}$.

Destarte, o julgamento realizado, embora fundado em cognição exauriente, somente se tornaria definitivo depois de confirmado pela sentença posteriormente proferida ${ }^{474}$ :haveria decisão calcada em cognição plena dos elementos de informação, mas, excepcionalmente, provisória $^{475}$.

Cumpre, novamente, utilizar o exemplo da ausência total e parcial de resposta do réu para ilustrar o entendimento dessa parcela da doutrina. Dúvida não há que a revelia total do réu enseja a presunção de veracidade das alegações do autor e, consequentemente, o julgamento antecipado da lide (art. 330, II, do CPC), com decisão apta ao trânsito em julgado material.

\footnotetext{
${ }^{471}$ Cfr. BONÍCIO, Marcelo José Magalhães. "Notas sobre a tutela antecipada 'parcial' na nova reforma do Código de Processo Civil", in Revista dos Tribunais, n. 808, fevereiro de 2003, p. 79.

${ }^{472}$ Cfr. DINAMARCO, Cândido Rangel. "A reforma da reforma", Malheiros, São Paulo, 2002, pp. 100102.

${ }^{473}$ Cfr. LUCON, Paulo Henrique dos Santos. "Estabilização da tutela antecipada e julgamento parcial do mérito", http://direitoprocessual.org.br/fileManager/Paulo_Lucon__Estabilizao_da_tutela_antecipada_e_julgame nto_parcial_do_mrito.doc, acessado em 10.1.12, p. 18.

${ }^{474}$ Cfr. LUCON, Paulo Henrique dos Santos. "Estabilização da tutela antecipada e julgamento parcial do mérito", http://direitoprocessual.org.br/fileManager/Paulo_Lucon_Estabilizao_da_tutela_antecipada_e_julgame nto_parcial_do_mrito.doc, acessado em 10.1.12, p. 25.

${ }_{475}$ Cfr. LOPES, João Batista. "Tutela antecipada no processo civil brasileiro", RT, São Paulo, $3^{\mathrm{a}}$ ed., 2007, pp. 177-178.
} 
Entretanto, a ausência parcial de impugnação não renderia a mesma consequência, justamente em razão da vedação legal à cisão do julgamento de mérito $^{476}$. Assim, mesmo estando presentes todos os requisitos autorizadores do julgamento antecipado da lide, o juiz deveria se limitar a antecipar os efeitos práticos dele decorrentes (art. 273, $\S 6^{\circ}$ ), devendo aguardar o momento processual oportuno, para, em uma só sentença, julgar a totalidade do objeto do processo.

É forçoso reconhecer que essa corrente perdeu fôlego com o advento da Lei n. 11.232/05, visto que rompido o dogma da unicidade do julgamento de mérito. Assim, admitida a possibilidade de cisão do exame do objeto do processo, esse entendimento acabará por desembocar no primeiro, já que a cognição plena permite prolação de decisão apta a solucionar o litígio definitivamente e a transitar materialmente em julgado - circunstância já reconhecida pela doutrina ${ }^{477}$.

De todo modo, caso, mesmo após a última reforma, seja negada a possibilidade de cindir o julgamento do mérito, não parece adequado afirmar que se trata de antecipação dos efeitos da tutela e, ao mesmo tempo, que a atividade cognitiva exercida pelo magistrado é exauriente.

Ora, se a cognição é realizada de forma plena, o juízo concebido será de certeza e não de probabilidade. O aprofundado exame da relação de direito material controvertida não é adequado à prolação de decisão antecipatória dos efeitos da tutela, a qual deve ser fundada em juízo de verossimilhança. A própria justificativa da existência da tutela antecipada é a impossibilidade de se aguardar o aprofundamento da atividade cognitiva em razão dos prejuízos decorrentes da insatisfação do direito alegado pelo autor.

Destarte, ainda que o legislador venha a denominar de provisória uma tutela definitiva, tal equívoco não tem o condão de alterar a natureza jurídica do provimento. Nesse sentido, se se considerar exaurientea atividade cognitiva

\footnotetext{
${ }^{476}$ Cfr. LOPES, João Batista. "Tutela antecipada no processo civil brasileiro", RT, São Paulo, $3^{\mathrm{a}}$ ed., 2007, p. 176.

${ }^{477}$ Cfr. SICA, Heitor Vitor Mendonça. “Preclusão processual civil”, Atlas, São Paulo, 2006, p. 205.
} 
exercida pelo juiz ao proferir decisão com fulcro no art. $273, \S 6^{\circ}$, do $\mathrm{CPC}$, a primeira corrente se mostra largamente preferível em relação à segunda, por conferir maior efetividade ao instrumento estatal de solução de litígios. A resolução definitiva da crise de direito material não pode ser postergada em razão de empecilhos formais desprovidos de qualquer teleologia. Repita-se: a forma não pode ser considerada como um fim em si mesmo.

Finalmente, chega-se à terceira posição existente na doutrina: o art. $273, \S 6^{\circ}$, do CPC, prevê hipótese de antecipação dos efeitos da tutela, com requisitos próprios, mas, ainda assim, provisória e revogável, visto que concedida por decisão fundada em juízo de verossimilhança.

Não obstante o legislador tenha se referido a "antecipação de tutela" ao redigir o art. 273, a doutrina é pacífica ao considerar que tal expressão deve ser lida como antecipação dos efeitos da tutela, e não da própria tutela. Nesse sentido, é importante observar que foi empregada no $\S 6^{\circ}$ a expressão "também", circunstância que revela ter o legislador se referido de forma inequívoca aos casos do caput do art. 273: hipóteses de antecipação dos efeitos da tutela. Além disso, se de julgamento antecipado se tratasse, a técnica processual em tela teria sido inserta na Seção “Do Julgamento Antecipado da Lide", ao lado do art. 330, do Código ${ }^{478}$.

Contudo, é cediço que na atividade hermenêutica a interpretação gramatical deve ser tida apenas como ponto de partida ${ }^{479}$. Apesar de mostrar-se favorável ao fim que ora se propõe, esse método não tem o condão de esgotar o assunto, devendo a investigação prosseguir.

De extrema utilidade à correta determinação da natureza jurídica da tutela jurisdicional é o critério que leva em conta sua estrutura. Sob esse prisma, a tutela pode ser definitiva e final ou provisória e instrumental.

\footnotetext{
${ }^{478}$ Cfr. VAZ, Paulo Afonso Brum. "Tutela antecipada fundada na técnica da ausência de controvérsia sobre o pedido ( $\$ 6^{\circ}$ do art. 273 do CPC)", in Revista de Processo, n. 131, p. 138.

${ }^{479}$ Cfr. FERRAZ JUNIOR, Tércio Sampaio. "Introdução ao estudo do direito: técnica, decisão, dominação", $2^{\mathrm{a}}$ ed. Atlas, São Paulo, 1994, p. 287.
} 
A tutela jurisdicional definitiva e final é normalmente fundada em cognição exauriente e fruto de juízo de certeza, sendo destinada a solucionar de forma perene o litígio, por meio da aplicação coercitiva da regra de direito material ao conflito, encerrando, assim, a crise existente. É verificada, v.g., no julgamento antecipado da lide, o qual é proferido em cenário de suficiência probatória (art. 330, I, do Código) $)^{480}$.

Entretanto, excepcionalmente o legislador pode admiti-la com base em cognição sumária, assumindo como suficiente para sua produção o juízo de probabilidade do direito afirmado ${ }^{481}$. É o que ocorre em nosso sistema com o julgamento antecipado com base na revelia.

Por sua vez, a tutela jurisdicional provisória e instrumental é destinada a repelir o perigo de dano causado por algum acontecimento ou pelo mero estado de insatisfação do direito controvertido. Tem conteúdo conservativo ou antecipatório. Trata-se da hipótese contida no art. 273, do CPC, que prevê tutela jurisdicional inapta a solucionar definitivamente o litígio, visto que limitada à antecipação de alguns dos efeitos práticos decorrentes da futura tutela jurisdicional definitiva $^{482}$.

A tutela antecipada é concedida com base numa avaliação provisória dos dados acerca da questão a ser definida, orientando-se o magistrado por critérios de plausibilidade e verossimilhança do direito afirmado pelo demandante, sem analisar a procedência ou a improcedência do pedido ${ }^{483}$.

É dita sumária a cognição superficial, que não se aprofunda no sentido vertical ${ }^{484}$. Nesse sentido, a profundidade da cognição deve

\footnotetext{
${ }^{480}$ Cfr. BEDAQUE, José Roberto dos Santos. "Tutela cautelar e tutela antecipada: tutelas sumárias e de urgência (tentativa de sistematização)", $5^{\mathrm{a}}$ ed., Malheiros, São Paulo, 2009, p. 366.

${ }^{481}$ Cfr. BEDAQUE, José Roberto dos Santos. "Tutela cautelar e tutela antecipada: tutelas sumárias e de urgência (tentativa de sistematização)”, $5^{\mathrm{a}}$ ed., Malheiros, São Paulo, 2009, p. 366.

${ }^{482}$ Cfr. BEDAQUE, José Roberto dos Santos. "Tutela cautelar e tutela antecipada: tutelas sumárias e de urgência (tentativa de sistematização)", $5^{\text {a }}$ ed., Malheiros, São Paulo, 2009, pp. 366-368.

${ }^{483}$ Cfr. SILVA, Ovídio Araújo Baptista da. "Conteúdo da sentença e mérito da causa”, in Sentença e coisa julgada: ensaios e pareceres, $4^{\mathrm{a}}$ ed., Forense, Rio de Janeiro, 2006, p. 234.

${ }^{484}$ Cfr. WATANABE, Kazuo. "Da cognição no processo civil", 2 ed., CEBEPEJ, São Paulo, 1999, p. 125.
} 
guardar relação de adequação com o momento do procedimento em que ocorre o exame pelo juiz, com a natureza dos fatos alegados e do direito discutido, com a natureza do provimento judicial pleiteado e com as demais especificidades do caso concreto. A cognição sumária não serve, via de regra, à declaração da certeza de um direito, mas, sim, como instrumento de sua tutela ${ }^{485}$.

No mais, as decisões fundadas em cognição superficial não tem aptidão à aquisição da autoridade da coisa julgada material ${ }^{486}$. Não se trata, portanto, de decisões de mérito, pois: (i) dada sua provisoriedade, o provimento limitarse-ia a regular o conflito de interesses no curso do processo; e (ii) tem eficácia meramente endoprocessual ${ }^{487}$.

Nessa linha, a ausência de controvérsia por falta de impugnação não tem o condão de gerar certeza jurídica, não ensejando atividade de cognição exauriente. O julgamento daí decorrente é baseado em verossimilhança, visto que não há exame aprofundado da relação jurídica de direito material trazida a Juízo: analisa-se o mérito apenas à luz das alegações tecidas pelo autor.

Se o réu não contesta algum dos pedidos ou parcela do pedido, incide uma presunção relativa de veracidade sobre as consequiências jurídicas pretendidas pelo autor, em razão da incontrovérsia existente. Ocorre que essa presunção - justamente por ser relativa - admite contrariedade, de modo que o réu poderá pleitear a produção de provas em sentido contrário, as quais, sendo pertinentes, devem ser deferidas pelo juiz. Dispensa-se tão-somente o autor do ônus de provar o fato constitutivo de seu direito (art. 334, IV, do CPC), mas o réu terá o ônus e a possibilidade de afastar a presunção relativa que se instalou ${ }^{488}$.

\footnotetext{
${ }^{485}$ Cfr. WATANABE, Kazuo. "Da cognição no processo civil", $2^{\mathrm{a}}$ ed., CEBEPEJ, São Paulo, 1999, p. 128.

${ }^{486}$ Cfr. WATANABE, Kazuo. "Da cognição no processo civil", 2a ed., CEBEPEJ, São Paulo, 1999, p. 142.

${ }^{487}$ Cfr. SILVA, Ovídio Araújo Baptista da. "Conteúdo da sentença e mérito da causa", in Sentença e coisa julgada: ensaios e pareceres, $4^{\text {a }}$ ed., Forense, Rio de Janeiro, 2006, p. 237.

${ }^{488}$ Cfr. RIBEIRO, Darci Guimarães. "A garantia constitucional do contraditório e as presunções contidas no $\$ 6^{\circ}$ do art. 273 do CPC", in ARMELIN, Donaldo (coord.). "Tutelas de urgência e cautelares: estudos em homenagem a Ovídio Araújo Baptista da Silva”, Saraiva, São Paulo, 2010, pp. 353-354.
} 
É importante observar que o direito de defesa mediante exercício do regular contraditório não se esgota na fase postulatória (apresentação de contestação), mostrando-se presente ao longo de todo o processo ${ }^{489}$.

Assim, a antecipação de tutela concedida pelo juiz com base no art. 273, $\S 6^{\circ}$, não impede o réu de buscar produzir provas em sentido contrário à presunção relativa de veracidade das alegações tecidas pelo autor, instalada em razão da incontrovérsia formal ${ }^{490}$.

O legislador não adotou técnica de tutela sumária e definitiva. Autorizou somente medida provisória, fundada na incontrovérsia, sendo inerente a tal provimento judicial sua revogabilidade e a reversibilidade de seus efeitos $^{491}$.

Quanto ao ponto, afirma JOSÉ ROBERTO DOS SANTOS BEDAQUE que a decisão proferida por meio do art. $273, \S 6^{\circ}$, assim como a sentença de mérito fundada em revelia, é fruto de juízo de verossimilhança. Assim, nas duas hipóteses haveria presunções legais que "não produzem convicção no espírito do julgador, que se limita a impor a consequência prevista em lei, sem prévia cognição exauriente sobre a situação fática" ${ }^{, 492}$.

Existindo cumulação de pedidos ou pedido único cindível e ausência de impugnação em relação a sua totalidade, a antecipação dos efeitos da futura tutela se justifica em razão da verossimilhança das alegações e da inexistência de controvérsia sobre a pretensão. É situação semelhante à da revelia, na qual a presunção

\footnotetext{
${ }^{489}$ Cfr. RIBEIRO, Darci Guimarães. "A garantia constitucional do contraditório e as presunções contidas no $\$ 6^{\circ}$ do art. 273 do CPC", in ARMELIN, Donaldo (coord.). "Tutelas de urgência e cautelares: estudos em homenagem a Ovídio Araújo Baptista da Silva”, Saraiva, São Paulo, 2010, p. 354.

${ }^{490}$ Cfr. RIBEIRO, Darci Guimarães. "A garantia constitucional do contraditório e as presunções contidas no $\$ 6^{\circ}$ do art. 273 do CPC", in ARMELIN, Donaldo (coord.). "Tutelas de urgência e cautelares: estudos em homenagem a Ovídio Araújo Baptista da Silva”, Saraiva, São Paulo, 2010, p. 354.

${ }^{491}$ Cfr. BEDAQUE, José Roberto dos Santos. "Tutela cautelar e tutela antecipada: tutelas sumárias e de urgência (tentativa de sistematização)", $5^{\mathrm{a}}$ ed., Malheiros, São Paulo, 2009, p. 361.

${ }^{492} \mathrm{Cfr}$. BEDAQUE, José Roberto dos Santos. "Tutela cautelar e tutela antecipada: tutelas sumárias e de urgência (tentativa de sistematização)", $5^{\text {a }}$ ed., Malheiros, São Paulo, 2009, nota de rodapé n. 119, pp. 361-362.
} 
de veracidade dos fatos e o consequente julgamento antecipado podem ser afastados (artigos 319 e 333, II, do CPC), caso a narração contida na inicial não seja plausível ${ }^{493}$.

Aponta-se que considerar o art. 273, $\S 6^{\circ}$, como tutela antecipada implicaria a necessidade de sua confirmação, modificação ou de revogação na sentença ao final proferida. Tal situação geraria uma incongruência, pois conferiria ao réu contumaz a dupla oportunidade de impugnar matéria em relação a qual desde o início não teve interesse em controverter (agravo de instrumento contra a antecipação e apelação contra a sentença). Haveria, assim, grave ameaça à segurança jurídica e a celeridade da marcha processual $^{494}$.

Entretanto, o óbice aventado encontra solução relativamente simples. Se o réu voluntariamente deixou de contestar determinado pedido, sobre o qual incidiu a antecipação de tutela, ter-se-ia configurado fato impeditivo de seu direito de recorrer: se no primeiro momento concordou com as alegações do autor, não pode posteriormente vir a impugná-las, tendo ocorrido, assim, preclusão lógica. Destarte, mantido o mesmo cenário processual probatório, o réu não poderia insurgir-se contra a tutela antecipada concedida.

Portanto, a instrução probatória seria assim aproveitada pelas partes e pelo magistrado:

(i) em relação à parcela do objeto processual incontroversa, o bem da vida estaria na posse do autor (se concedida a antecipação de tutela), liberando-o de qualquer ônus probatório e assegurando-se ao réu a possibilidade de produzir provas que elidam a presunção relativa estabelecida contra si;

\footnotetext{
${ }^{493}$ Cfr. BEDAQUE, José Roberto dos Santos. "Tutela cautelar e tutela antecipada: tutelas sumárias e de urgência (tentativa de sistematização)", $5^{\mathrm{a}}$ ed., Malheiros, São Paulo, 2009, p. 361.

${ }^{494}$ Cfr. TERRA, Rogério Luiz dos Santos. "A antecipação de tutela do pedido incontroverso: questões polêmicas derivadas do art. 273, $\S 6^{\circ}$, do Código de Processo Civil", in Revista Forense, vol. 412, pp. 259-260.
} 
(ii) no tocante ao pedido controvertido, o bem da vida, via de regra, permaneceria na posse do réu, sendo que ambas as partes deverão convencer o juiz da veracidade de suas alegações ${ }^{495}$.

$\mathrm{O}$ art. 273, $\S 6^{\circ}$, compreende apenas autorização para a antecipação dos efeitos da tutela de pedido ou parcela de pedido não controvertidos pelo réu ${ }^{496}$, não configurando hipótese de sentença ou interlocutória definitiva parcial $^{497}$.

Trata-se de decisão fundada em cognição sumária, tendo natureza provisória ${ }^{498}$.Contudo, é importante observar que o legislador atribuiu à contumácia do réu a consequência de autorização ao julgamento antecipado da lide nas hipóteses de revelia total, criando excepcional situação de tutela sumária e definitiva. Por que, então, adotar solução diversa nos casos de revelia parcial e total, se ambas as situações são, em tese, substancialmente idênticas?

Argumenta-se que pode haver dúvidas acerca da extensão da contestação, dificultando a identificação de pedidos que tenham sido efetivamente controvertidos, ainda que implicitamente ${ }^{499}$.

Além disso, aceitar que se forme a coisa julgada material sobre parcela da demanda, a partir de simples presunção relativa de veracidade decorrente de não impugnação, é desconsiderar que eventual aprofundamento da cognição possa revelar que um fato comum a todas as pretensões não ocorreu conforme alegado na petição inicial ${ }^{500}$.

\footnotetext{
495 Cfr. RIBEIRO, Darci Guimarães. "A garantia constitucional do contraditório e as presunções contidas no $\S 6^{\circ}$ do art. 273 do CPC", in ARMELIN, Donaldo (coord.). "Tutelas de urgência e cautelares: estudos em homenagem a Ovídio Araújo Baptista da Silva”, Saraiva, São Paulo, 2010, p. 357.

${ }^{496} \mathrm{Cfr}$. VAZ, Paulo Afonso Brum. "Tutela antecipada fundada na técnica da ausência de controvérsia sobre o pedido ( $\$ 6^{\circ}$ do art. 273 do CPC)", in Revista de Processo, n. 131, p. 141.

${ }^{497}$ Cfr. NOTARIANO JUNIOR, Antonio; BRUSCHI, Gilberto Gomes. "O julgamento antecipado da lide e a antecipação de tutela em caso de pedidos incontroversos", in ARMELIN, Donaldo (coord.). "Tutelas de urgência e cautelares: estudos em homenagem a Ovídio A. Baptista da Silva”, Saraiva, São Paulo, 2010, pp. 133-134.

${ }^{498}$ Cfr. RIBEIRO, Darci Guimarães. "A garantia constitucional do contraditório e as presunções contidas no $\S 6^{\circ}$ do art. 273 do CPC", in ARMELIN, Donaldo (coord.). "Tutelas de urgência e cautelares: estudos em homenagem a Ovídio Araújo Baptista da Silva", Saraiva, São Paulo, 2010, p. 356.

${ }^{499}$ Cfr. CARNEIRO, Athos Gusmão. "Da antecipação de tutela", Forense, Rio de Janeiro, 2002, p. 60.

${ }^{500}$ Cfr. OLIVEIRA, Bruno Silveira de. "Um novo conceito de sentença?" in Revista de Processo, n. 149, RT, São Paulo, julho de 2007, pp. 129-130.
} 
Imagine-se que o autor ajuíze demanda com pedidos condenatórios, versando indenização por danos morais e materiais decorrentes de acidente automobilístico. O réu contesta, impugnando apenas os danos morais, sob a alegação de não ter o autor os experimentado. Diante disso, o juiz antecipa a tutela, com base no art. $273, \S 6^{\circ}$, do CPC, no tocante ao pedido de indenização por danos materiais, não tendo as partes interposto qualquer recurso. Durante a instrução probatória resta demonstrado que o causador do acidente na verdade foi o próprio autor, visto que, instantes antes da colisão, desrespeitou as regras de trânsito.

Se se considerar que a antecipação concedida foi somente de efeitos da tutela, nada obstará o julgamento de improcedência integral da demanda; se se considerar antecipada a própria tutela, a decisão a respeito dos danos materiais não poderá ser revista, visto que transitada materialmente em julgado.

Não há dúvidas acerca da possibilidade de conflito lógico entre duas coisas julgadas ${ }^{501}$. No entanto, tal situação deve ser evitada, ainda mais se se tratar de decisões proferidas no mesmo processo, sendo uma delas fundada em mera cognição sumária dos elementos de informação ${ }^{502}$.

Ademais, considerar o art. $273, \S 6^{\circ}$, como antecipação dos efeitos da tutela atende aos objetivos previstos pelo legislador quando de sua edição: colocar imediatamente o bem da vida na posse do autor que, aparentemente, tem razão. É inegável a eficácia do regime de efetivação dos efeitos antecipados da tutela, destinados à imediata satisfação do direito do autor ${ }^{503}$.

Diante disso, com o prosseguimento do processo, poderá o juiz concluir pela improcedência do pedido incontroverso, cassando a tutela antecipada

\footnotetext{
${ }^{501}$ Cfr. CHIOVENDA, Giuseppe. "Instituições de direito processual civil", Bookseller, Campinas, 2009, p. 495.

${ }_{502}$ As hipóteses de reconhecimento jurídico parcial do pedido, transação parcial, renúncia parcial e suficiência probatória em relação a parcela do objeto do processo ensejam prolação de decisão fundada em cognição exauriente, não estando insertas, portanto, no campo de aplicação do art. 273 , § $6^{\circ}$, do CPC, que se limita a situações de cognição superficial, como adiante se verá.

${ }_{503}$ Cfr. VAZ, Paulo Afonso Brum. "Tutela antecipada fundada na técnica da ausência de controvérsia sobre o pedido ( $\$ 6^{\circ}$ do art. 273 do CPC)", in Revista de Processo, n. 131, p. 139.
} 
eventualmente concedida ${ }^{504}$. No caso de revelia total essa situação, em regra, não se verificará, já que a integralidade do objeto processual será examinada a um só tempo, não havendo margem para a prolação de decisões contraditórias no mesmo processo.

Estabelecidas essas premissas, é de se concluir que não existe razão para conferir interpretação extensiva ao art. 330, II, do CPC, aos casos de incontrovérsia parcial por não impugnação, conferindo matizes de definitividade a uma decisão fundada em cognição superficial, vocacionada, portanto, à provisoriedade, pois instrumental.

Sendo assim, é possível constatar que a técnica inserta no $\S 6^{\circ}$ do art. 273 é tipicamente uma antecipação dos efeitos da tutela final ${ }^{505}$, e não a antecipação da própria tutela, pois:

(i) não é fundada em cognição exauriente, visto que proferida em cenário de ausência de impugnação especificada dos fatos, capaz de gerar tão-somente presunção relativa de veracidade das alegações do autor;

(ii) apesar de situação semelhante à da revelia total, não há aqui expressa autorização legal para a concessão de tutela definitiva com base em cognição sumária;

(iii) não se destina a solucionar de forma definitiva o litígio;

(iv) visa a afastar os efeitos deletérios do tempo causados pelo estado de insatisfação do direito pleiteado.

Há, ainda, quem entenda que se trate de decisão que antecipa efeitos práticos da tutela final, inapta a transitar materialmente em julgado, mas que ficaria acobertada pela preclusão, não sendo necessário seu reexame quando da prolação da sentença. Assim, a decisão final apenas faria menção à antecipação concedida, julgando prejudicado o referido pedido: como não há resistência seria

\footnotetext{
${ }^{504}$ Cfr. BEDAQUE, José Roberto dos Santos. "Tutela cautelar e tutela antecipada: tutelas sumárias e de urgência (tentativa de sistematização)", $5^{\mathrm{a}}$ ed., Malheiros, São Paulo, 2009, p. 369.

${ }^{505} \mathrm{C} \mathrm{fr}$. BEDAQUE, José Roberto dos Santos. "Tutela cautelar e tutela antecipada: tutelas sumárias e de urgência (tentativa de sistematização)", $5^{\text {a }}$ ed., Malheiros, São Paulo, 2009, p. 369.
} 
desnecessária a tutela jurisdicional, de modo a implicar ausência de interesse de agir em relação à parcela incontroversa da demanda ${ }^{506}$.

Entretanto, não se pode concordar com tal solução. As condições da ação devem ser analisadas in statuassertionis, ou seja, à luz das informações narradas na petição inicial.O fato de a matéria restar incontrovertida, longe de implicar carência de ação por falta de interesse de agir, indica situação em que o magistrado, ao sentenciar, deve resolver essa parcela do litígio com julgamento de mérito, porque presente situação autorizadora da procedência da demanda.

Se há condições de solucionar o litígio de forma definitiva, com decisão apta a adquirir a qualidade de coisa julgada material, não há sentido em prejudicar o autor que tem razão, concedendo-lhe tutela jurisdicional menos intensa que aquela efetivamente devida.

Verificada a natureza de antecipação de efeitos da tutela, concedida por decisão fundada em cognição sumária dos elementos de informação presentes nos autos, resta analisar os requisitos para a aplicação da técnica contida no art. 273, $\S 6^{\circ}$, do Código de Processo Civil.

Dispõe o Código que poderá haver concessão de tutela antecipada "quando um ou mais dos pedidos cumulados, ou parcela deles, mostrar-se incontroverso".

Apesar de a letra da lei fazer referência a "um ou mais dos pedidos cumulados ou parcela deles", deve-se admitir a aplicação da técnica sempre que a controvérsia girar apenas sobre parte de pedido único decomponível ${ }^{507}$.

\footnotetext{
506 Trata-se do entendimento adotado por ROGÉRIO LUIZ DOS SANTOS TERRA: "A solução de julgar prejudicado determinado tema encontra ampla aceitação nos usos e costumes do Poder Judiciário, ao deparar-se o magistrado com situação faticamente consolidada e que não mais represente uma 'pretensão resistida' de modo que sobre tal ponto (assim tido por prejudicado) não mais seja necessária a tutela jurisdicional" (cfr. "A antecipação de tutela do pedido incontroverso: questões polêmicas derivadas do art. 273, $\S 6^{\circ}$, do Código de Processo Civil", in Revista Forense, vol. 412, p. 259).

${ }^{507}$ Cfr. BEDAQUE, José Roberto dos Santos. "Tutela cautelar e tutela antecipada: tutelas sumárias e de urgência (tentativa de sistematização)", $5^{\mathrm{a}}$ ed., Malheiros, São Paulo, 2009, p. 362; v. tb. ZAVASCKI, Teori Albino. "Antecipação da tutela em face de pedido incontroverso", in Revista Jurídica, n. 301, novembro de 2002, pp. 30 e 33; VAZ, Paulo Afonso Brum. "Tutela antecipada fundada na técnica da ausência de controvérsia sobre o pedido ( $\$ 6^{\circ}$ do art. 273 do CPC)", in Revista de Processo, n. 131, p.
} 
O dispositivo comporta, portanto, interpretação extensiva, podendo incidir também nas hipóteses de pedido único decomponível formulado pelo autor e de demanda formulada pelo réu (v.g., reconvenção, pedido contraposto) ${ }^{508}$. Assim, deve incidir sempre que a incontrovérsia permitir antecipação dos efeitos da tutela em relação a parcela do objeto do processo: Lex minus dixit quamvoluit ${ }^{509}$.

Há na doutrina quem afirme que a incontrovérsia de pedido, ou de parte dele, ocorre em três hipóteses ${ }^{510}$ :

(i) não contestação (incontrovérsia fática);

(ii) reconhecimento jurídico parcial do pedido, renúncia parcial ou transação parcial (incontrovérsia jurídica); e

(iii) suficiência probatória (incontrovérsia fática e

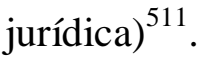

Entretanto, para fins de aplicação do art. $273, \S 6^{\circ}$, do CPC, somente se deve considerar adequada a primeira das situações, já que a única em que o magistrado exerce atividade cognitiva superficial. As duas últimas consubstanciam hipótese em que o juízo proferido pelo magistrado será fundado em cognição exauriente, configurando caso de prolação de sentença parcial de mérito, nos exatos termos dos artigos $162, \S 1^{\circ}$, e 269 , do $\mathrm{CPC}^{512}$.

129; SOUZA JUNIOR, Sidney Pereira de. "Sentenças parciais no processo civil - consequências no âmbito recursal", Método, São Paulo, 2009, p. 110.

${ }^{508}$ Cfr. DINAMARCO, Cândido Rangel. "A reforma da reforma", Malheiros, São Paulo, 2002, p. 94.

${ }^{509}$ Cfr. DINAMARCO, Cândido Rangel. "A reforma da reforma”, Malheiros, São Paulo, 2002, p. 94.

${ }^{510} \mathrm{Cfr}$. MITIDIERO, Daniel. "Direito fundamental ao julgamento definitivo da parcela incontroversa: uma proposta de compreensão do art. $273, \S 6^{\circ}$, CPC, na perspectiva do direito fundamental a um processo sem dilações indevidas (art. $5^{\circ}$, LXXVIII, CF/88)", in Revista de Processo, n. 149, pp. 109-110.

${ }^{511}$ Cfr. SANT'ANNA, Paulo Afonso de Souza. "Hipóteses para concessão da tutela antecipatória da parte incontroversa da demanda (art. 273, $\S 6^{\circ}, C P C$ )", in Revista de Processo, n. 121, p. 119.

${ }_{512}$ Sobre a manifesta disparidade entre as situações e a necessidade de tratá-las diferenciadamente, afirma JOSÉ ROBERTO DOS SANTOS BEDAQUE que "a antecipação fundada na ausência parcial de controvérsia não se confunde com as situações em que, por força de atos unilaterais ou bilaterais, a pretensão é total ou parcialmente admitida (arts. 269, inc. II e III). Aqui há manifestação expressa de vontade e a decisão homologatória não tem natureza provisória. Se o reconhecimento ou a transação versar sobre parte do pedido, essa parcela será definitivamente excluída do processo. Existe diferença ontológica entre reconhecer a eficácia a atos expressos de disposição das partes e presumir que a falta de controvérsia implica aceitação da pretensão pelo réu" (cfr. "Tutela cautelar e tutela antecipada: tutelas sumárias e de urgência (tentativa de sistematização)", $5^{\text {a }}$ ed., Malheiros, São Paulo, 2009, p. 363).

CÂNDIDO RANGEL DINAMARCo também sinaliza que as hipóteses não devem ser confundidas, já que geram consequências jurídicas flagrantemente distintas: "A situação do art. $273, \S 6^{\circ}$, não se 
Nessa linha, as situações em que o réu reconhece parcialmente o pedido, as partes celebram transação parcial ou o autor desiste parcialmente do direito material discutido são diferentes da mera ausência de impugnação. Em tais casos não há qualquer presunção relativa passível de elisão mediante dilação probatória, visto que se está diante de certeza jurídica, pois configurada uma das hipóteses previstas nos artigos 269, do CPC (incisos II, III e V). Assim, não configuram cenário apto a ensejar a incidência do art. $273, \S 6^{\circ}$, mas caso de julgamento fracionado de mérito por meio de sentença parcial ${ }^{513}$.

O legislador se referiu a pedido incontroverso e não a fatos incontroversos, pois nem sempre sobre esses incidem as consequências jurídicas buscadas pelo autor. Destarte, o fato pode ser incontroverso, mas o pedido pode não encontrar respaldo na ordem jurídica, de modo que a antecipação de tutela não poderá ser concedida ${ }^{514}$. Trata-se da aplicação dos brocardos latinos da mihifactumdabotibiiuse iuranovitcuria $^{515}$.

Nem sempre o silêncio do réu leva à procedência da pretensão do autor. O juiz deve verificar se daqueles fatos, sobre os quais recai presunção relativa de veracidade, decorrem as consequências jurídicas pleiteadas pelo demandante ${ }^{516}$.

Destarte, a incontrovérsia deve levar em conta também a convicção do juiz, que deve considerar verossímil a versão dos fatos trazida pelo

confunde com o reconhecimento do pedido (art. 269, II), a renúncia ao direito (art. 269, V) ou a transação (art. 269, IV) (p. 98). O art. 273, $\S 6^{\circ}$, cuida da incontrovérsia quanto aos fatos, enquanto os demais dispositivos da incontrovérsia quanto ao direito" (cfr. "A reforma da reforma", Malheiros, São Paulo, 2002, p. 99).

513 Cfr. RIBEIRO, Darci Guimarães. "A garantia constitucional do contraditório e as presunções contidas no $\$ 6^{\circ}$ do art. 273 do CPC", in ARMELIN, Donaldo (coord.). "Tutelas de urgência e cautelares: estudos em homenagem a Ovídio Araújo Baptista da Silva”, Saraiva, São Paulo, 2010, p. 358.

${ }^{514}$ Cfr. VAZ, Paulo Afonso Brum. "Tutela antecipada fundada na técnica da ausência de controvérsia sobre o pedido ( $\$ 6^{\circ}$ do art. 273 do CPC)", in Revista de Processo, n. 131, p. 131; v. tb. RIBEIRO, Darci Guimarães. "A garantia constitucional do contraditório e as presunções contidas no $\S 6^{\circ}$ do art. 273 do $C P C$ ", in ARMELIN, Donaldo (coord.). "Tutelas de urgência e cautelares: estudos em homenagem a Ovídio Araújo Baptista da Silva”, Saraiva, São Paulo, 2010, p. 353.

515 Cfr. SANT'ANNA, Paulo Afonso de Souza. "Hipóteses para concessão da tutela antecipatória da parte incontroversa da demanda (art. 273, $\$ 6^{\circ}, C P C$ )”, in Revista de Processo, n. 121, p. 120.

${ }_{516}$ Cfr. DORIA, Rogéria Dotti. "A tutela antecipada em relação à parte incontroversa da demanda", RT, São Paulo, 2004, p. 93. 
autor $^{517}$, de modo que se se mostrar manifesta a improcedência da pretensão do demandante, a mera ausência de impugnação não ensejará a concessão da tutela $\operatorname{antecipada}^{518}$.

Além disso, a contestação parcial, apta a gerar presunção relativa de veracidade em relação às alegações não controvertidas, deve ser entendida de forma mais ampla, alcançando toda situação em que, sendo ônus exclusivamente seu, o réu deixe de produzir determinada prova pertinente ou requeira sua produção apenas em relação a parte dos fatos apresentados em sua resposta ${ }^{519}$.

Há, ainda, na doutrina, posicionamento que confere uma interpretação ainda mais elástica ao dispositivo legal, no sentido de que a contestação desprovida de razoabilidade e de seriedade deve, também, dar ensejo à incidência do art. $273, \S 6^{\circ}$. Assim, atentando-se à finalidade da norma, afirma-se que se os fundamentos da contestação forem manifestamente descabidos ou improcedentes, deverá o pedido ser considerado incontroverso ${ }^{520}$.

Dúvidas não há de que a aferição de "razoabilidade" e de "seriedade" é tarefa dotada de elevado grau de subjetivismo, o que conduziria a indesejada situação de insegurança jurídica. Entretanto, são indicadas algumas balizas objetivas para auxiliar o aplicador do direito, as quais cumpririam a função de nortear a interpretação e de dotar o sistema da previsibilidade necessária:

(i) contestação fundada exclusivamente na negativa de fato

notório (art. 334, I);

(ii) defesa fundada na negativa de fato que goze de presunção legal de veracidade (art. 334, IV);

\footnotetext{
${ }^{517}$ Cfr. ZAVASCKI, Teori Albino. "Antecipação da tutela em face de pedido incontroverso", in Revista Jurídica, n. 301, novembro de 2002, p. 32.

${ }^{518}$ Cfr. ZAVASCKI, Teori Albino. "Antecipação da tutela em face de pedido incontroverso", in Revista Jurídica, n. 301, novembro de 2002, p. 31.

${ }^{519}$ Cfr. LUCON, Paulo Henrique dos Santos. "Estabilização da tutela antecipada e julgamento parcial do mérito", disponível

em http://direitoprocessual.org.br/fileManager/Paulo_Lucon_Estabilizao_da_tutela_antecipada_e_julgame nto_parcial_do_mrito.doc, acessado em 10.1.12,p. 15 .

${ }_{520}$ Cfr. ZAVASCKI, Teori Albino. "Antecipação da tutela em face de pedido incontroverso", in Revista Jurídica, n. 301, novembro de 2002, p. 32.
} 
(iii) contestação com fundamento que contraria decisões de caráter vinculante (v.g., controle concentrado de constitucionalidade; súmulas vinculantes);

(iv) defesa fundada em entendimento contrário à jurisprudência dominante dos Tribunais Superiores ${ }^{521}$.

Todavia, por mais ampla que seja a interpretação visando a extrair a máxima efetividade da técnica em tela, há limites a se observar na definição da incontrovérsia apta a ensejar a antecipação dos efeitos da tutela. Havendo controvérsia jurídica, a confissão, em depoimento pessoal, apenas sobre os fatos, não autoriza a antecipação de tutela ${ }^{522}$. Idêntica consequência se verifica com a defesa de mérito indireta, por meio da qual o réu, embora concordando com os fatos constitutivos narrados na inicial, traz fato impeditivo, modificativo ou extintivo do direito do autor (artigos 326 e 333, II, do CPC) ${ }^{523}$. Além das defesas de mérito indiretas, diante de alegação de empecilhos de ordem processual, como litispendência, coisa julgada, incompetência ou carência de ação, não poderá incidir o art. $273, \S 6^{\circ}$, ainda que não controvertido diretamente o pedido do autor ${ }^{524}$.

Nessa linha, a ausência de impugnação, seja total ou parcial, somente ocorre se houver citação válida, verificando-se nas seguintes situações:

(i) réu não comparece em juízo tempestivamente;

(ii) réu comparece em juízo, mas não apresenta

contestação;

(iii) réu apresenta contestação, mas não impugna de forma específica os fatos;

\footnotetext{
${ }^{521}$ Cfr. ZAVASCKI, Teori Albino. "Antecipação da tutela em face de pedido incontroverso", in Revista Jurídica, n. 301, novembro de 2002, pp. 32-33.

${ }^{522}$ Cfr. VAZ, Paulo Afonso Brum. "Tutela antecipada fundada na técnica da ausência de controvérsia sobre o pedido ( $\$ 6^{\circ}$ do art. 273 do CPC)", in Revista de Processo, n. 131, p. 132.

${ }^{523}$ Cfr. BONÍCIO, Marcelo José Magalhães. "Notas sobre a tutela antecipada 'parcial' na nova reforma do Código de Processo Civil", in Revista dos Tribunais, n. 808, fevereiro de 2003, p. 73; v. tb. VAZ, Paulo Afonso Brum. "Tutela antecipada fundada na técnica da ausência de controvérsia sobre o pedido $\left(\S 6^{\circ}\right.$ do art. 273 do CPC)", in Revista de Processo, n. 131, p. 132; SANT'ANNA, Paulo Afonso de Souza. "Hipóteses para concessão da tutela antecipatória da parte incontroversa da demanda (art. 273, $\S 6^{\circ}$, CPC)", in Revista de Processo, n. 121, p. 120.

${ }_{524}$ Cfr. ZAVASCKI, Teori Albino. "Antecipação da tutela em face de pedido incontroverso", in Revista Jurídica, n. 301, novembro de 2002, p. 32.
} 
(iv) réu apresenta contestação, mas impugna apenas

parcela dos fatos ${ }^{525}$

Contudo, a ausência de impugnação, por si só, não gera a presunção relativa de veracidade das alegações do autor. $\mathrm{O}$ descumprimento, pelo réu, do ônus da impugnação específica somente trará tal consequência se ausentes as causas obstativas previstas nos artigos 302 e 320, do CPC:

(i) fatos que não admitem confissão, aqui também entendidos os relativos a direitos indisponíveis;

(ii) petição inicial desacompanhada de instrumento público necessário à comprovação dos fatos;

(iii) matéria unicamente de direito; e

(iv) fatos alegados na inicial contrariados pela defesa, considerada em seu conjunto, ou, então, por contestação oferecida por algum dos demais litisconsortes ${ }^{526}$.

Diante disso, há na doutrina quem afirme que a antecipação de tutela da parcela incontroversa do objeto processual não pode ser concedida nos casos em que não incidem os efeitos da revelia ${ }^{527}$.

Nesse sentido, é corrente a afirmação de que se se tratar de direitos indisponíveis, havendo contestação parcial, não seria possível a antecipação da tutela, tendo em vista que a confissão, a revelia e a não contestação nessa situação não geram consequências desfavoráveis ao réu ${ }^{528}$.

\footnotetext{
${ }^{525}$ Cfr. VAZ, Paulo Afonso Brum. "Tutela antecipada fundada na técnica da ausência de controvérsia sobre o pedido ( $\$ 6^{\circ}$ do art. 273 do CPC)", in Revista de Processo, n. 131, p. 131.

${ }^{526}$ Cfr. LUCON, Paulo Henrique dos Santos. "Estabilização da tutela antecipada e julgamento parcial do mérito", disponível http://direitoprocessual.org.br/fileManager/Paulo_Lucon_Estabilizao_da_tutela_antecipada_e_julgame nto_parcial_do_mrito.doc, acessado em 10.1.12, pp. 15-16; v. tb. SANT'ANNA, Paulo Afonso de Souza. "Hipóteses para concessão da tutela antecipatória da parte incontroversa da demanda (art. 273, $\$ 6^{\circ}$, CPC)", in Revista de Processo, n. 121, p. 119.

${ }^{227}$ Cfr. FERREIRA, William Santos. "Aspectos polêmicos e práticos da nova reforma processual civil", Forense, Rio de Janeiro, 2003, p. 203.

${ }^{528}$ Cfr. DORIA, Rogéria Dotti. "A tutela antecipada em relação à parte incontroversa da demanda", RT, São Paulo, 2004, pp. 107-108.
} 
Somente poderia ser aplicado o art. $273, \S 6^{\circ}$, do CPC, no caso de demandas versando direitos disponíveis. A indisponibilidade impediria a incidência da presunção de veracidade dos fatos narrados na inicial, em razão do manifesto interesse público existente nessa categoria de direitos ${ }^{529}$.

Assim, diante da indisponibilidade do direito, embora haja incontrovérsia formal entre as partes, a lei impõe ao juiz que examine com profundidade o pedido do autor, não incidindo qualquer presunção de veracidade ${ }^{530}$.

Todavia, parece necessário examinar a teleologia da vedação contida nos artigos 302 e 320, do CPC. Trata-se de hipóteses em que, não obstante tenha o réu deixado de contrariar alegações do autor, sobre essas não incidiria presunção de veracidade, de modo a obstar o julgamento antecipado (art. 330 c.c. art. 319, do CPC).

Conforme afirmado acima, o julgamento com base em revelia total é medida excepcional adota pelo legislador, o qual, em razão da contumácia do réu, autorizou, de forma atípica, a resolução definitiva do litígio com base em cognição superficial dos elementos de informação presentes nos autos. Em hipótese especial, a lei autoriza o magistrado a conceder tutela jurisdicional sumária e definitiva.

Diante disso, é possível concluir que, ao estabelecer situações em que se veda a presunção de veracidade decorrente da não impugnação, o legislador nada mais fez que excepcionar a excepcional regra autorizadora de julgamento definitivo com base em cognição sumária. Nos casos acima listados, em razão do interesse público existente no direito discutido, o julgamento antecipado e definitivo da lide estaria obstado, devendo a instrução processual prosseguir, a fim de possibilitar ao magistrado proferir decisão fundada em cognição exauriente. Assim, nas referidas hipóteses, quis o legislador que o procedimento seguisse seu curso normal, devendo o juiz conceder tutela jurisdicional fundada em cognição plena.

\footnotetext{
${ }^{529}$ Cfr. BONÍCIO, Marcelo José Magalhães. "Notas sobre a tutela antecipada 'parcial' na nova reforma do Código de Processo Civil", in Revista dos Tribunais, n. 808, fevereiro de 2003, p. 74.

${ }_{530}$ Cfr. ZAVASCKI, Teori Albino. "Antecipação da tutela em face de pedido incontroverso", in Revista Jurídica, n. 301, novembro de 2002, p. 32.
} 
Ocorre que o art. 273, $\S 6^{\circ}$, é antecipação de efeitos da tutela, concedida com base em cognição sumária, não contemplando situação de julgamento antecipado e definitivo da parcela do objeto processual incontrovertida. Desse modo, não parece adequado trazer para seu campo de aplicação os óbices previstos pela lei quanto ao julgamento definitivo fundado em cognição superficial.

Apesar de proferidas com arrimo em cognição dotada de semelhante profundidade, não há qualquer correspondência entre as decisões que julgam antecipadamente a lide com base em revelia total e as que somente antecipam efeitos de tutela jurisdicional futura em relação a parcela incontrovertida do objeto processual. Às primeiras o legislador atribuiu excepcional definitividade, enquanto as segundas são perfeitamente revogáveis no curso do procedimento. Destarte, onde não há a mesma razão, não pode incidir o mesmo direito.

Dessa forma, é de se concluir ser o art. $273, \S 6^{\circ}$, do CPC, perfeitamente aplicável às hipóteses em que não se verificam os efeitos da revelia, bastando haver incontrovérsia das alegações do autor e as consequências jurídicas por ele pretendidas serem, em tese, compatíveis com o ordenamento jurídico.

Suponha-se que o autor ajuíze contra determinado município ação declaratória de inexistência de débitos tributários, referentes a IPTU e ISS. Caso houvesse revelia total, o julgamento antecipado da lide estaria obstado, tendo em vista a indisponibilidade do direito discutido ${ }^{531}$ : incidiria a vedação legal de concessão de tutela definitiva com base em cognição sumária. Entretanto, caso o ente público contestasse apenas a pretensão referente ao ISS, deixando incontrovertidos os fatos quanto ao IPTU, nada obstaria que o magistrado, com base na cognição sumária dos elementos presentes nos autos, antecipasse os efeitos da declaração pretendida pelo autor em relação a esse tributo. Proferiria, assim, decisão provisória e revogável, aplicando-se de forma efetiva o art. $273, \S 6^{\circ}$, do CPC, sem incidir em qualquer óbice legal, teórico ou prático.

\footnotetext{
${ }^{531}$ Cfr. AgRg no REsp n. 1.137.177-SP, STJ, $2^{\text {a }}$ T., Rel. Min. HUMBERTO MARTINS, j. 18.2.10, in DJe de 2.3.10; EDcl no REsp n. 724.111-RJ, STJ, $1^{\text {a }}$ T., Rel. Min. LUIZ FUX, j. 17.12.09, inDJe de 12.2.10.
} 
No mais, tem-se entendido que a técnica não alcança as situações em que o pedido não impugnado seja dependente de outro pedido, regularmente controvertido, como sói ocorrer na cumulação sucessiva de pedidos.

Nesse caso, se o autor pleitear o reconhecimento da paternidade e a condenação ao pagamento de alimentos, ainda que o réu conteste apenas o pedido declaratório não será possível ao juiz antecipar a tutela, com base no art. $273, \S$ $6^{\circ}$, em relação ao pedido condenatório. Outro exemplo: autor requer a anulação do contrato e a condenação do réu a pagar os prejuízos existentes. Ainda que o réu impugne apenas o pedido desconstitutivo, não poderá ser antecipada a tutela em relação ao pedido condenatório ${ }^{532}$.

Trata-se de nexo de dependência muito semelhante àquele verificado no art. 248, do CPC, atinente ao campo das nulidades processuais. Uma vez anulado um ato processual, todos aqueles que dele dependam também deverão ser $\operatorname{atingidos}^{533}$.

Seriam, em síntese, três os requisitos necessários à incidência do art. 273, $\S 6^{\circ}$ : (i) incontrovérsia do pedido; (ii) verossimilhança das alegações; (iii) não subordinação do pedido incontroverso a questão prejudicial ${ }^{534}$.

Como se trata de antecipação dos efeitos da tutela, é necessário prévio requerimento do autor, pois é inviável, via de regra, sua concessão exofficiopelo magistrado ${ }^{535}$.

\footnotetext{
${ }^{532}$ Cfr. BONÍCIO, Marcelo José Magalhães. "Notas sobre a tutela antecipada 'parcial' na nova reforma do Código de Processo Civil", in Revista dos Tribunais, n. 808, fevereiro de 2003, p. 76-77.

${ }^{533}$ Cfr. BONÍCIO, Marcelo José Magalhães. "Notas sobre a tutela antecipada 'parcial' na nova reforma do Código de Processo Civil", in Revista dos Tribunais, n. 808, fevereiro de 2003, p. 76.

${ }_{534}$ Cfr. ZAVASCKI, Teori Albino. "Antecipação da tutela em face de pedido incontroverso", in Revista Jurídica, n. 301, novembro de 2002, p. 33.

${ }^{535} \mathrm{Cfr}$. VAZ, Paulo Afonso Brum. "Tutela antecipada fundada na técnica da ausência de controvérsia sobre o pedido ( $\$ 6^{\circ}$ do art. 273 do CPC)", in Revista de Processo, n. 131, p. 134.

Entretanto, se se considerar hipótese de julgamento antecipado parcial, tal requerimento será desnecessário, pois ao órgão jurisdicional compete a direção do processo, devendo velar pela pronta solução do litígio (art. 125, II, do CPC) (cfr. MITIDIERO, Daniel. "Direito fundamental ao julgamento definitivo da parcela incontroversa: uma proposta de compreensão do art. $273, \S 6^{\circ}, C P C, n a$ perspectiva do direito fundamental a um processo sem dilações indevidas (art. $5^{\circ}$, LXXVIII, CF/88)", in Revista de Processo, n. 149, p. 112).
} 
Para a concessão dessa modalidade de tutela antecipada não se exigem o risco de dano irreparável ou de difícil reparação ${ }^{536}$. Não é necessário o periculum in mora $^{537}$ ou o propósito protelatório do réu, bastando a incontrovérsia em relação a parcela dos pedidos ${ }^{538}$.

Afirma-se que a irreversibilidade dos efeitos antecipados também não é requisito a ser observado ${ }^{539}$, visto que na antecipação concedida com fulcro no art. $273, \S 6^{\circ}$, o risco de o magistrado errar é baixíssimo ${ }^{540}$, em razão da presunção de veracidade dos fatos e da dispensa de produção de provas (artigos $302 \mathrm{e}$ 334, III e IV, do CPC) ${ }^{541}$. Contudo, é possível a concessão da antecipação de tutela com base em parcial incontrovérsiasem a concomitante incidência de presunção de veracidade (v.g., direitos indisponíveis), situação em que a reversibilidade do provimento deve ser observada.

Entende-se que não se aplica a revogabilidade das tutelas de urgência ${ }^{542}$. No entanto, embora se trate de antecipação de tutela fundada na incontrovérsia sobre o pedido, sua revogação pelo magistrado se mostra admissível, sempre que o aprofundamento da cognição demonstrar a improcedência do pedido do autor.

Ainda para a parcela da doutrina que entende ser extremamente improvável a revogação da medida concedida, é possível pensar em alguns casos em que essa necessariamente deverá ocorrer. Se houver colusão entre as partes para prejudicar terceiros, o juiz deverá, ao saber da fraude, revogar a antecipação

\footnotetext{
${ }^{536}$ Cfr. VAZ, Paulo Afonso Brum. "Tutela antecipada fundada na técnica da ausência de controvérsia sobre o pedido ( $\$ 6^{\circ}$ do art. 273 do CPC)", in Revista de Processo, n. 131, p. 135.

${ }_{537}$ Cfr. DINAMARCO, Cândido Rangel. "A reforma da reforma", Malheiros, São Paulo, 2002, pp. 9697.

${ }^{538}$ Cfr. BONÍCIO, Marcelo José Magalhães. "Notas sobre a tutela antecipada 'parcial' na nova reforma do Código de Processo Civil", in Revista dos Tribunais, n. 808, fevereiro de 2003, p. 77.

${ }_{539}$ Cfr. BONÍCIO, Marcelo José Magalhães. "Notas sobre a tutela antecipada 'parcial' na nova reforma do Código de Processo Civil", in Revista dos Tribunais, n. 808, fevereiro de 2003, p. 77; v. tb. VAZ, Paulo Afonso Brum. "Tutela antecipada fundada na técnica da ausência de controvérsia sobre o pedido ( $\$ 6^{\circ}$ do art. 273 do CPC)", in Revista de Processo, n. 131, p. 135; DORIA, Rogéria Dotti. "A tutela antecipada em relação à parte incontroversa da demanda", RT, São Paulo, 2004, pp. 124-125.

${ }^{540} \mathrm{Cfr}$. BONÍCIO, Marcelo José Magalhães. "Notas sobre a tutela antecipada 'parcial' na nova reforma do Código de Processo Civil", in Revista dos Tribunais, n. 808, fevereiro de 2003, p. 77.

${ }^{541}$ Cfr. DINAMARCO, Cândido Rangel. "A reforma da reforma", Malheiros, São Paulo, 2002, p. 97.

${ }^{542}$ Cfr. AYOUB, Luiz Roberto; PELLEGRINO, Antônio Pedro. "A sentença parcial", in Revista de Arbitragem e Mediação, n. 22, RT, São Paulo, jul.-set./2009, p. 45.
} 
concedida e extinguir o processo sem resolução de mérito ${ }^{543}$. Outra hipótese de revogação admitida pela doutrina se verifica nos casos de revelia em que a contumácia poderia ser relevada, tendo o réu deixado de contestar por ignorância ou outra razão de natureza social. Por fim, é possível revogação na hipótese de devolução do prazo para contestar (art. 183, $\S 1^{\mathrm{o}}$ e $2^{\mathrm{o}}$, do CPC) ${ }^{544}$.

Assim, a decisão proferida com fulcro no art. $273, \S 6^{\circ}$, do Código de Processo Civil, pode ser revista a qualquer momento (art. 273, § $4^{\circ}$, do CPC) e deverá ser necessariamente confirmada na sentença ${ }^{545}$. Trata-se de antecipação dos efeitos da tutela: outorga-se antecipadamente a eficácia social da futura sentença ${ }^{546}$. Assim, aplicam-se, em princípio, o regime geral previsto no art. 273: (i) é necessário requerimento da parte; (ii) é possível haver revogação ou modificação a qualquer tempo; (iii) tem caráter provisório ${ }^{547}$.

Por fim, nota-se que a lógica do sistema não foi observada pelo legislador reformador ${ }^{548}$. De um lado, é cediço que a revelia total induz, ao menos em princípio, julgamento antecipado, nos termos dos artigos 319 e 330, II, do Código. Proferida a sentença nessa condição, eventual recurso de apelação interposto será dotado de efeito suspensivo (art. 520, do CPC), obstando a realização de execução provisória. De outro lado, se houver revelia parcial, poderão, em tese, ser antecipados os efeitos da futura tutela jurisdicional, os quais serão passíveis de imediata efetivação. Ao final, proferida a sentença e confirmada a antecipação anteriormente concedida, os respectivos efeitos não sofrerão qualquer alteração.

\footnotetext{
${ }^{543}$ Cfr. ZAVASCKI, Teori Albino. "Antecipação da tutela em face de pedido incontroverso", in Revista Jurídica, n. 301, novembro de 2002, pp. 31-32.

${ }^{544}$ Cfr. VAZ, Paulo Afonso Brum. "Tutela antecipada fundada na técnica da ausência de controvérsia sobre o pedido ( $\$ 6^{\circ}$ do art. 273 do CPC)”, in Revista de Processo, n. 131, pp. 135-136.

${ }^{545}$ Cfr. BONÍCIO, Marcelo José Magalhães. "Notas sobre a tutela antecipada 'parcial' na nova reforma do Código de Processo Civil", in Revista dos Tribunais, n. 808, fevereiro de 2003, p. 79.

Entretanto, para quem entende que se trata de julgamento parcial antecipado, é totalmente descabido falar em revogação, visto que a sentença é dotada de definitividade. Além disso, não se exigiria o requisito de reversibilidade, já que se trataria de provimento com caráter definitivo, apto a ser objeto de execução definitiva (cfr. ARAÚJO, José Henrique Mouta. "Tutela antecipada do pedido incontroverso: estamos preparados para a nova sistemática processual?", in Revista de Processo, n. 116, p. 218).

${ }^{546} \mathrm{Cfr}$. ZAVASCKI, Teori Albino. "Antecipação da tutela em face de pedido incontroverso", in Revista Jurídica, n. 301, novembro de 2002, pp. 33-34.

${ }^{547}$ Cfr. ZAVASCKI, Teori Albino. "Antecipação da tutela em face de pedido incontroverso", in Revista Jurídica, n. 301, novembro de 2002, p. 34.

${ }_{548}$ Cfr. LOPES, João Batista. "Tutela antecipada no processo civil brasileiro", RT, São Paulo, $3^{\mathrm{a}}$ ed., 2007, p. 177.
} 
Nítida a incongruência, visto que a decisão antecipatória seria mais eficaz que o próprio provimento definitivo. Destarte, cumpre ao intérprete corrigir a imperfeição legislativa ${ }^{549}$. Ainda que haja pedido único e esse seja incontroverso, sendo hipótese, portanto, de incidência do art. 330, do CPC, deve ser concomitantemente antecipada a tutela com fulcro no art. $273, \S 6^{\circ}$, a fim de que eventual recurso de apelação interposto pelo réu seja recebido apenas no efeito devolutivo, abrindo-se ao autor as portas da execução provisória. Caso assim não se procedesse, estar-se-ia criando situação que fere a razoabilidade, já que a sentença proferida seria menos eficaz que a antecipação dos efeitos da tutela ${ }^{550}$.

Em resumo, a Lei n. 10.444/02 foi o marco que despertou a doutrina pátria para a necessidade de desacumulação de demandas no curso do processo $^{551}$. Com o art. $273, \S 6^{\circ}$, o legislador deu um passo em direção à cindibilidade da sentença, permitindo o exame antecipado de um dos pedidos não impugnados ${ }^{552}$.

Com a inclusão do $\S 6^{\circ}$ no art. 273 , do CPC, criou-se nova modalidade de tutela antecipada, passível de concessão em razão da parcial ausência de controvérsia, sendo desnecessária a presença dos requisitos previstos nos incisos I e II do art. 273. Contudo, falta, ainda, ao legislador harmonizar a eficácia dos julgamentos proferidos com fundamento em incontrovérsia, incluindo um inciso ao art. 520, do CPC, de forma a possibilitar que o julgamento proferido com base em revelia seja imediatamente eficaz ${ }^{553}$.

É importante observar que não há qualquer óbice no sistema ao julgamento antecipado parcial, com decisão dotada de definitividade e apta ao trânsito em julgado, com o prosseguimento do processo em relação à parte controvertida. Entretanto, conforme assevera BEDAQUE, "a simples antecipação de

\footnotetext{
${ }^{549}$ Cfr. BEDAQUE, José Roberto dos Santos. "Tutela cautelar e tutela antecipada: tutelas sumárias e de urgência (tentativa de sistematização)", $5^{\text {a }}$ ed., Malheiros, São Paulo, 2009, p. 363.

${ }^{550} \mathrm{Cfr}$. VAZ, Paulo Afonso Brum. "Tutela antecipada fundada na técnica da ausência de controvérsia sobre o pedido ( $\$ 6^{\circ}$ do art. 273 do CPC)", in Revista de Processo, n. 131, pp. 129-130.

${ }^{551} \mathrm{Cfr}$. SICA, Heitor Vitor Mendonça. "Algumas implicações do novo conceito de sentença, de acordo com a Lei n. 11.232/2005", in CARMONA, Carlos Alberto (coord.). Reflexões sobre a reforma do Código de Processo Civil, Atlas, São Paulo, 2007, p. 195.

${ }^{552}$ Cfr. BONÍCIO, Marcelo José Magalhães. "Notas sobre a tutela antecipada 'parcial' na nova reforma do Código de Processo Civil", in Revista dos Tribunais, n. 808, fevereiro de 2003, pp. 73-74.

${ }_{553} \mathrm{Cfr}$. BEDAQUE, José Roberto dos Santos. "Tutela cautelar e tutela antecipada: tutelas sumárias e de urgência (tentativa de sistematização)", $5^{\text {a }}$ ed., Malheiros, São Paulo, 2009, p. 369.
} 
efeitos não gera resultado definitivo, pois nada obsta que o juiz, durante a instrução, entenda inexistente o direito, embora incontroversa a afirmação do autor. É claro que a contestação parcial torna altamente provável o acolhimento da pretensão não atacada, mas não está afastada a possibilidade de improcedência do pedido, cujos efeitos foram antecipados por força do $\S 6^{o, 554}$.

Assim, a sentença parcial de mérito é categoria autônoma, devendo ser reservada para os cenários de certeza jurídica e de suficiência probatória, sendo possível concluir pela convivência harmoniosa entre as duas técnicas no ordenamento jurídico.

Dessa forma, é possível separar bem os dois cenários. Na hipótese contida no art. 273, § $6^{\circ}$, do CPC, o juiz concede antecipação dos efeitos da tutela, visto que, diante de ausência de impugnação específica, profere decisão baseada em cognição superficial, incidente sobre o objeto processual incontroverso, mas passível de modificação por meio de instrução probatória. Trata-se, portanto, de decisão interlocutória fundada em juízo de verossimilhança, provisória e revogável. De outro lado, caso não haja mera ausência de impugnação, mas verdadeiro cenário de suficiência probatória ou de certeza jurídica, o juiz antecipará a própria tutela, proferindo sentença parcial de mérito, dotada de definitividade e apta a adquirir a qualidade de coisa julgada material ${ }^{555}$.

Aceitar que se forme a coisa julgada material sobre parcela da demanda, a partir de simples presunção relativa de veracidade decorrente de não impugnação, é desconsiderar que eventual aprofundamento da cognição possa revelar que um fato comum a todas as pretensões não ocorreu conforme alegado na petição inicial $^{556}$. Assim, a antecipação de tutela evitaria eventual conflito entre julgados, caso fato comum a todos os pedidos viesse a ser demonstrado de forma diferente de como

\footnotetext{
${ }^{554}$ Cfr. BEDAQUE, José Roberto dos Santos. "Tutela cautelar e tutela antecipada: tutelas sumárias e de urgência (tentativa de sistematização)", $5^{\mathrm{a}}$ ed., Malheiros, São Paulo, 2009, p. 362.

${ }_{555}$ Cfr. RIBEIRO, Darci Guimarães. "A garantia constitucional do contraditório e as presunções contidas no $\S 6^{\circ}$ do art. 273 do CPC", in ARMELIN, Donaldo (coord.). "Tutelas de urgência e cautelares: estudos em homenagem a Ovídio Araújo Baptista da Silva”, Saraiva, São Paulo, 2010, p. 359.

${ }_{556}$ Cfr. OLIVEIRA, Bruno Silveira de. "Um novo conceito de sentença?" in Revista de Processo, n. 149, RT, São Paulo, julho de 2007, pp. 129-130.
} 
narrado na inicial, assegurando a harmonia entre decisões prolatadas no mesmo processo $^{557}$.

Considerar o art. $273, \S 6^{\circ}$, como antecipação dos efeitos da tutela é solução adequada, pois produz os efeitos práticos desejados, sem retirar do magistrado a possibilidade de revogar a antecipação, caso conclua, à luz dos elementos de cognição posteriormente produzidos, pela improcedência do pedido, ainda que incontroverso 558 .

Destarte, o entendimento ora defendido permite extrair consequências práticas úteis do art. $273, \S 6^{\circ}$, do CPC, salvando-o da revogação tácita ao diferenciá-lo das hipóteses de julgamento antecipado de parcela do objeto processual por meio de sentença parcial.

\subsection{TRATAMENTO DA MATÉRIA NO DIREITO ESTRANGEIRO}

Cumpre verificar breve notícia acerca de como alguns ordenamentos jurídicos estrangeiros contemplam a cisão do julgamento de mérito.

$\mathrm{Na}$ Itália, entende-se que o legislador não pode simplesmente limitar a noção de sentença ao ato final de julgamento, pois, em atenção ao princípio dell'adattabilitàdel processo alleesigenzedella causa, é perfeitamente possível que o Collegiose encontre em situação na qual não é possível esgotar sua função jurisdicional com apenas uma sentenza definitiva ${ }^{559}$.

Nessa linha, o princípio da concentração está expresso no comma 1 do art. 277, do CodicediProceduraCivile, segundo o qual

${ }^{557}$ Cfr. OLIVEIRA, Bruno Silveira de. "Um novo conceito de sentença?" in Revista de Processo, n. 149, RT, São Paulo, julho de 2007, p. 131.

${ }^{558}$ Cfr. BEDAQUE, José Roberto dos Santos. "Tutela cautelar e tutela antecipada: tutelas sumárias e de urgência (tentativa de sistematização)", $5^{\mathrm{a}}$ ed., Malheiros, São Paulo, 2009, pp. 362-363.

${ }^{559} \mathrm{Cfr}$. CAMARDI, Giuseppe. "Le sentenze non definitive su questioni preliminari di mérito", tesi di dottorato apresentada à Universitá di Bologna, disponível em <http://amsdottorato.cib.unibo.it/771/1/Tesi_Camardi_Giuseppe.pdf>, acessado em 16.7.2012, pp. 24-25. 
"ilCollegioneldeliberare sul merito deve decideretutteledomandeproposte". No entanto, conforme apontam Federico CARPI, VitTORIO COLESANTI e Michele TARUfFO, há exceções: "a fronte del principio generale enunciato nel c. 1 dell'articolo in esame, il legislatore del codice ha introdotto alcune deroghe allo scopo di conferire elasticità e capacità di adattamento al sistema. Sono infatti previste eccezioni al principio di concentrazione, in base alle quali il collegio pronuncia sentenze che non esauriscono la materia del contendere e che non definiscono il giudizio"560.

Os exemplos mais clarosde exceção à regra da unicidade de julgamento de mérito são os artigos 277, comma2, e 278, do Codice ${ }^{561}$.

OCodicediProceduraCivile prevê expressamente as sentenças parciais no art. 277, o qual, em seu comma 2, dispõe que o Collegio, ao verificar que algumas demandas prescindam de ulterior instrução, enquanto outras ainda necessitem de maior dilação probatória, poderá decidir imediatamente as que estejam maduras para julgamento ${ }^{562}$.

Nesses casos, afirma a doutrina italiana que decisão parcial exaure totalmente o pedido em relação à parcela da demanda decidida, sendo dotada de definitividade ${ }^{563}$.

Para a aplicação da técnica em tela é imprescindível a presença de dois requisitos ${ }^{564}$ :

(i) a existência simultânea de demandas maduras para julgamento e de outras que necessitem de maior instrução probatória;

\footnotetext{
${ }^{560} \mathrm{Cfr}$. "Commentario breve al codice di procedura civile”, $4^{\mathrm{a}}$ ed., Padova: CEDAM, 2002, p. 828.

${ }^{561}$ Cfr. MANDRIOLI, Crisanto. "Diritto processuale civile”, v. II, 14a ed., Torino, 2002, p. 287

${ }^{562}$ Cfr. DALL'ALBA, Felipe Camilo. “Julgamento antecipado ou antecipação dos efeitos da tutela do pedido incontroverso?", in Revista de Processo, n. 128, p. 219.

${ }^{563}$ Nesse sentido, assevera FRANCESCO PAOLO LUISO: "la sentenza exaurisce in maniera completa la richiesta de tutela relativa ad uma domanda, e respetto a questa la sentenza è definitiva, perché la sucessiva sentenza, relativa ad uma diversa domanda, na é in grado di assorbine la portata procettiva, com invece accade per la sentenze non definitive"" (cfr. "Diritto processuale civile", 2a ed., Giuffrè, Milano, 1999, p. 192).

${ }^{564}$ Cfr. CAMARDI, Giuseppe. "Le sentenze non definitive su questioni preliminari di mérito", tesi di dottorato apresentada à Universitá di Bologna, disponível em <http://amsdottorato.cib.unibo.it/771/1/Tesi_Camardi_Giuseppe.pdf>, acessado em 16.7.2012, p. 151.
} 
(ii) o manifesto interesse da parte no imediato julgamento da parcela madura do objeto litigioso do processo.

Assim, exemplificando, no direito italiano é perfeitamente viável que, em demanda contendo pedidos de resolução de contrato e de ressarcimento de danos, o órgão julgador declare a extinção da avença e remeta o pedido indenizatório à instrução. A decisão sobre a parcela restante do mérito não terá qualquer influência sobre aquela já resolvida por sentença parcial ${ }^{565}$.

Há outra hipótese de julgamento fracionado do mérito no direito italiano. De acordo com o art. 278, segunda parte, o Collegio, em caso de condenação ilíquida, pode, desde logo, condenar o réu ao pagamento de quantia que já esteja provada. Apesar de o Codice identificar essa decisão como uma provvisionale, entende-se que se trata, na verdade, de uma sentenzaparzialedimerito, apta à aquisição da qualidade de coisa julgada material ${ }^{566}$.

A utilidade do instituto é significativa, visto que reduz o tempo necessário à satisfação do direito do autor. Ao possibilitar que o credor obtenha imediatamente o que já está comprovado, sem que seja necessário aguardar a prova do montante integral do dano, a técnica reduz sensivelmente a duração patológica do processo $^{567}$.

Não obstante isso, a corrente doutrinária majoritária entende que o órgão julgador não pode cindir o julgamento, emitindo condannagenerica,sem que haja pedido da parte, sob pena de violação ao princípio da adstrição ${ }^{568}$.

\footnotetext{
${ }^{565}$ Cfr. LUISO, Francesco Paolo. "Diritto processuale civile", $2^{\mathrm{a}}$ ed., Giuffrè, Milano, 1999, pp. 193-194.

${ }^{566}$ ANDREA PROTO PISANI assim identifica a hipótese em tela: "qualora nel corso del processo venga raggiunta la prova non solo dell'illegittimità dell'ato e dela sua potenzialità danosa (an), ma venga provata anche una parte dell'ammontare del danno (uma parte del quantum), sempre e solo su istanza di parte, il giudice può accoppiare ala sentenza di condanna genérica anche uma sentenza parziale, di condanna in senso stretto, com cui inizia la liquidazione del danno (condanna provvisionale)" (cfr. "Lezioni di diritto processuale civile", Napoli, Jovene, 1994, p. 188).

${ }^{567}$ Cfr. PISANI, Andrea Proto. "Lezioni di diritto processuale civile", Napoli, Jovene, 1994, p. 188.

${ }^{568} \mathrm{Cfr}$. CAMARDI, Giuseppe. "Le sentenze non definitive su questioni preliminari di mérito", tesi di dottorato apresentada à Universitá di Bologna, disponível em $<$ http://amsdottorato.cib.unibo.it/771/1/Tesi_Camardi_Giuseppe.pdf>, acessado em 16.7.2012, pp. 217218.
} 
Além dessas duas hipóteses em relação às quais não há muita divergência, existeuma terceira situação no sistema processual civil italiano que costuma ser apontada como hipótese de julgamento fracionado do mérito. Trata-se da previsão contida no art. 279, comma 2, n. 4, segundo o qual o Collegio pronuncia sentenza "quando, decidendo alcune delle questioni di cui ai numeri 1, 2 e 3, non definisce il giudizio e impartisce distinti provvedimenti per l'ulteriore istruzione della causa".

Entretanto, muito se discute acerca do seu conteúdo, entendendo, parcela da doutrina, que o juiz poderia fracionar o julgamento não apenas por demanda, mas também por questão de mérito ${ }^{569}$, o que ampliaria sobremaneira o conteúdo das sentenze $e^{570}$. O tema é controvertido, havendo três correntes a seu respeito $^{571}$ :

(i) privilegiando uma interpretação literal, a sentenza non definitiva pode ser proferida para decidir qualquer questão de mérito;

(ii) o termo "questioni" não deve ser interpretado de forma puramente técnica, de modo que a sentenza non definitiva deve ser proferida apenas no julgamento de demandas e não de meras questões;

(iii) a norma autoriza, ao mesmo tempo, a prolação de sentenças que decidam questões de mérito e sentenças que decidam algumas demandas.

Essa discussão, no sistema processual brasileiro, seria análoga àquela envolvendo a possibilidade de desacumulação de fundamentos da demanda ou da defesa, no curso do processo. Como já afirmado no tópico

\footnotetext{
${ }^{569}$ É o entendimento de LUIGI MONTESANO: "in particolare, l'attuale art. 279 consente la sentenza parziale non solo su questioni 'preliminari', cioè potenzialmente definitive di tutta la causa (ad es. , quando sia giudicata una eccezione di prescrizione o di carente interesse olegittimazione ad causam), ma pur quando il giudice, investito dell'esame unitario di una domanda, ritenga possibile, allo stato del processo, risolvere e precludere ogni contestazione sui singoli aspetti della stessa domanda, ancorché non decisivi sul se, sul come o sul quanto del suo accoglimento o rigetto [...]" (cfr. "Sentenza parziale su questione di merito non 'preliminare' di domanda 'indivisibile", in Riv. dir. proc. 1970, p. 330).

${ }^{570} \mathrm{Cfr}$. CAMARDI, Giuseppe. "Le sentenze non definitive su questioni preliminari di mérito", tesi di dottorato apresentada à Universitá di Bologna, disponível em <http://amsdottorato.cib.unibo.it/771/1/Tesi_Camardi_Giuseppe.pdf>, acessado em 16.7.2012, pp. 61-62.

${ }^{571} \mathrm{Cfr}$. CAMARDI, Giuseppe. "Le sentenze non definitive su questioni preliminari di mérito", tesi di dottorato apresentada à Universitá di Bologna, disponível em <http://amsdottorato.cib.unibo.it/771/1/Tesi_Camardi_Giuseppe.pdf〉, acessado em 16.7.2012, pp. 66-69.
} 
correspondente, entende-se não ser possível o fracionamento do julgamento de questões, por ofensa ao disposto nos artigos $2^{\circ}, 5^{\circ}, 325,458$, II e 459, do Código de Processo Civil.

Há, ainda, outro ponto controvertido na doutrina italiana envolvendo a cisão do julgamento do mérito. Na cumulação de demandas entre os mesmos sujeitos processuais, há quem afirme que a decisão que analisa apenas uma delas, com prosseguimento do procedimento, mas sem determinar a separação do processo e sem analisar sucumbência, é sentenza non definitiva, devendo ser objeto de riserva de impugnazione. É a posição majoritária ${ }^{572}$. Há, também, o entendimento de que se trata de sentenza definitiva e não suscetível de riserva de impugnazione ${ }^{573}$. A distinção é relevante justamente pela possibilidade ou não de imediata impugnação do ato decisório $^{574}$.

Finalmente, à semelhança do quanto afirmado em relação ao Brasil após o advento da Emenda Constitucional n. 66/10, no direito italiano é admitido o fracionamento do julgamento de mérito em relação às ações de separação judicial e de divórcio, conforme previsto, respectivamente, nos artigos 709-bis, do Codice, e $4^{\circ}$, comma12, da legge $898 / 1970^{575}$.

\footnotetext{
${ }^{572}$ É de se observar que o fato de ser denominada de non definitiva não faz com que a sentenza seja privisória, tendo relação apenas com a extensão do objeto processual por ela analisado: " $L a$ giurisprudenza distingue tra sentenze definitive e non definitive, nel senso che è definitive la decisione che esarisca l'oggeto della controversia, attribuendo o negando il bene in contestazione, senza necessità di ulteriore pronunce sul l'oggeto della domanda cui si riferisce la decisione del giudizio (Cass. 14 settembre 1972, n. 2378) mentre no è definitiva la sentenza che, nell'ipotesi di più questione relative alla stessa domanda, ne decida una, dispondendo l'ulteriore instruzione (Cass. 18 aprile 1977, n. 1422; Cass. 11 novembre 1974, n. 3539). Ovviamente le statuizioni della sentenza non definitiva non possono essere modificate dalla sentenza definitiva, perchè il carattere definitivo si riferisce solo all non integralità della decisione (Cass. 5 novembre 1977, n. 4720)" (cfr. SATTA, Salvatore. Diritto processuale civile, Padova: Casa Editrice Dott. Antonio Milani, 1981, p. 365).

${ }^{573} \mathrm{Cfr}$. CAMARDI, Giuseppe. "Le sentenze non definitive su questioni preliminari di mérito", tesi di dottorato apresentada à Universitá di Bologna, disponível em <http://amsdottorato.cib.unibo.it/771/1/Tesi_Camardi_Giuseppe.pdf>, acessado em 16.7.2012, pp. 131137.

${ }^{574}$ Nessa linha, a definição da natureza do ato é importante para a correta identificação do recurso cabível: "Ė certo che il problema assume un rilevante aspetto pratico poiché la distinzione tra sentenza definitiva e non definitiva è determinante agli effetti dell'impugnabilità imediata" (cfr. COMOGLIO, Luigi Paolo; FERRI, Corrado; TARUFFO, Michele. "Lezioni sul processo civile", Bologna: Il Mulino, 1995, p. 650).

${ }^{575}$ De acordo com GIUSEPPE CAMARDI, "si tratta, evidentemente, di una disposizione che, con uma sentenza non definitiva non subordinata ad alcuna istanza di parte, mira a rendere più rapida la decisione sul divorzio, nell'ipotesi in cui le stesse parti si trovino d'accordo sul punto, ma siano, invece, 'in contrasto sulle domande accessorie di natura economica o su quelle che riguardano l'affidamento dei figli" (cfr. "Le sentenze non definitive su questioni preliminari di mérito", tesi di dottorato apresentada à Universitá 
No tocante a outros ordenamentos jurídicos, pode se

afirmar o seguinte:

(i) no Chile, o art. 172, do Codigo de Procedimiento Civil $^{576}$, prevê expressamente a possibilidade de desacumulação de demandas. Trata-se de regra que prestigia a economia processual, permitindo ao órgão julgador apreciar demandas cumuladas que amadurecerem antes das demais. Nesse caso, deverão ser formados autos suplementares para a execução da decisão parcial de mérito ${ }^{577}$;

(ii) na França, é possível, de acordo com o art. 544, do Nouveau Code de ProcédureCivile ${ }^{578}$, que as decisões interlocutórias decidam parte da questão principal, hipótese em que serão objeto de appel, sendo que a jurisprudência da Cour de Cassation apresenta grande controvérsia acerca do significado da expressão "partiedu principal" 579 ;

(iii) na Alemanha, é possível que decisões interlocutórias resolvam parte do objeto litigioso do processo, sendo consideradas como "julgamento final" (Endurteil) e recorríveis por apelação (Berufung) (ZPO, § 511) ${ }^{580}$.

(iv) em Portugal, a cisão do julgamento de mérito é admitida pelo art. 510, 5, do $\mathrm{CPC}^{581}$, em demandas envolvendo direito possessório,

<http://amsdottorato.cib.unibo.it/771/1/Tesi_Camardi_Giuseppe.pdf>, acessado em 16.7.2012, pp. 178179).

576 "Art. 172. Cuandoenunmismojuicio se ventilen dos o más cuestiones que puedan ser resueltas separada o parcialmente, sin que elloofrezcadificultad para la marcha delproceso, y alguna o algunas de dichascuestiones o parte de ellas, lleguen al estado de sentencia antes de que termine elprocedimientoenlas restantes, podráel tribunal fallar desde luegolasprimeras. En este caso se formará cuaderno separado con compulsas de todas laspiezasnecesarias para dictarelfallo y ejecutarlo, a costa del que solicite laseparación".

${ }^{577}$ Cfr. SEGUEL, Alejandro Romero. "La acumulación inicial de acciones", Santiago: Conosur, 2000, p. 18.

578 "Art. 544. Les jugements qui tranchentdansleurdispositifunepartie du principal etordonnentunemesured'instruction on unemesureprovisoirepeuventêtreimmédiatement frappes d'appelcomme les jugements qui tranchent tout le principal. Il en est de meme lorsque le jugement qui statue surune exception de procédure, une fin de non-recevoirou tout autre incident met fin à linstance". ${ }_{579}$ Cfr. WAMBIER, Teresa Arruda Alvim. "Os agravos no CPC brasileiro", $4^{\mathrm{a}}$ ed., RT, São Paulo, 2006, pp. 89-90.

${ }_{580}$ Cfr. WAMBIER, Teresa Arruda Alvim. "Os agravos no CPC brasileiro", $4^{\mathrm{a}}$ ed., RT, São Paulo, 2006, p. 90 .

581 “ARTIGO 510. ${ }^{\circ}$ (Despacho saneador)

[...] 
sendo a decisão proferida recorrível por apelação ${ }^{582}$. Além dessa disposição legal expressa, a doutrina admite uma aplicação extensiva da técnica, conforme ensina JosÉ JOÃo BAPTISTA: "no entanto, sempre que o estado do processo (face aos elementos de prova dele constantes neste momento) o permitir, sem necessidade portanto de mais provas, o juiz deverá conhecer e decidir sobre o mérito da causa, quanto à totalidade ou parte do pedido ou pedidos (incluindo o pedido reconvencional) ou sobre alguma exceção peremptória (invocada pelo réu ou do conhecimento oficioso), quer julgue procedente ou improcedente (já que a lei, após a revisão do CPC, não distingue, diferentemente do que sucedia anteriormente)". Nessas situações, "caso o juiz no saneador decida sobre o mérito da causa ou julgue procedente ou improcedente alguma exceção peremptória, o saneador terá o valor de sentença (é o chamado 'saneador-sentença'),"583.

5 - Nas acções destinadas à defesa da posse, se o réu apenas tiver invocado a titularidade do direito de propriedade, sem impugnar a posse do autor, e não puder apreciar-se logo aquela questão, o juiz ordena a imediata manutenção ou restituição da posse, sem prejuízo do que venha a decidir-se a final quanto à questão da titularidade do direito".

${ }^{582}$ Cfr. RIBEIRO, José Antunes. "Código de processo civil anotado", Coimbra: Verbo Jurídico, 2006, p. 224.

${ }^{583}$ Cfr. "Processo civil I: Parte geral e processo declarativo", 8 a ed., Coimbra: Coimbra Editora, 2006, pp. 413-414. 


\section{IMPLICACÕES NO SISTEMA RECURSAL}

Admitida a existência do julgamento fracionado do mérito mediante sentença parcial, a questão do recurso cabível contra tal pronunciamento judicial é tormentosa na doutrina.

\subsection{RECURSO CABÍVEL CONTRA A SENTENCA PARCIAL DE MÉRITO}

Afirma-se que a regra da correspondência dos recursos implicaria a necessidade de interposição de apelação, o que, por sua vez, traria tumulto processual incompatível com a finalidade da própria reforma trazida pela Lei $\mathrm{n}$. 11.232/2005. Isto porque, recebido o apelo, os autos do processo deveriam ser remetidos ao tribunal, inviabilizando por completo seu prosseguimento no tocante à parte da demanda ainda não decidida em primeiro grau de jurisdição ${ }^{584}$.

Outra dificuldade apontada pelos processualistas consiste na identificação do recurso cabível na hipótese de o juiz, no mesmo ato, excluir alguns dos litisconsortes passivos por ilegitimidade ad causam, reconhecer a prescrição da pretensão de parcela da pretensão do autor, e deferir tutela antecipada em relação à porção remanescente do pedido. Tal situação faria ressurgir discussão há muito superada, consistente na possibilidade de utilização de mais de um recurso contra a mesma decisão ${ }^{585}$.

Além disso, sustenta-se que as sugestões corriqueiramente ventiladas a fim de vencer os óbices indicados, consubstanciadas no manejo de agravo de instrumento ou de apelação "por instrumento", não poderiam ser adotadas, pois sua admissão contra a sentença parcial dependeria de atuação legislativa federal (art. 22, I, da Constituição da República), em razão dos princípios da tipicidade e da taxatividade

${ }^{584}$ Cfr. NEVES, Daniel Amorim Assumpção. “O novo conceito de sentença”, in Reforma do CPC: leis 11.187/2005, 11.232/2005, 11.276/2006, 11.276/2006 e 11.280/2006, RT, São Paulo, 2006, pp. 82-83.

585 Cfr. VAREJÃO, José Ricardo do Nascimento. “As classificações, a lei 11.232/2005 e o 'novo' conceito de sentença", in WAMBIER, Teresa Arruda Alvim (coord.). Aspectos Polêmicos da Nova Execução, 3: de títulos judiciais, Lei 11.232/2005, RT, São Paulo, 2006, p. 386. 
dos recursos. Diante disso, há expressiva corrente - a qual se pode até mesmo afirmar majoritária - considerando não ser viável a existência de tal provimento judicial em nosso sistema ${ }^{586}$.

Contudo, não se pode concordar com a conclusão acima, visto que torna inviável técnica processual de grande utilidade ao método estatal de resolução de conflitos.

Não se nega a existência de problemas práticos decorrentes do emprego do julgamento fracionado do mérito por meio de sentença $\operatorname{parcial}^{587}$. Ocorre que tais intempéries são passíveis de superação, sem traumas ao sistema e sem negativa de vigência às normas processuais integrantes do sistema de recursos. A partir da análise das hipóteses recursais que, em tese, poderiam ser utilizadas, buscar-se-á alcançar solução apta a propiciar os fins almejados ${ }^{588}$.

\footnotetext{
${ }^{586}$ Cfr. MACHADO, Daniel Carneiro. "O novo conceito de sentença e a natureza jurídica do ato judicial que resolve questões incidentais.", in Revista do Tribunal Regional da $1^{\text {a }}$ Região, v. 22, n. 4, abril de 2010, $\quad$ p. $9, \quad$ disponível em http://bdjur.stj.jus.br/xmlui/bitstream/handle/2011/34805/novo_conceito_senten\%C3\%A7a_machado.pdf ?sequence $=1$, acessado em 9.7.11.

587 Acerca do ponto, TERESA ARRUdA Alvim WAMBIER assevera que "A fragmentação da causa, com a admissibilidade de apelação contra cada uma das sentenças 'parciais' proferidas ao longo do processo antes da sentença 'final', com a consequente paralisação do procedimento, se admitida, protrairia a resolução integral da lide, o que não é desejável, e contraria a finalidade do processo, que é a resolução integral e o mais rapidamente possível da lide" (cfr. "Os agravos no CPC brasileiro", $4^{\mathrm{a}}$ ed., RT, São Paulo, 2006, p. 113).

${ }^{588}$ Nesse sentido, afirma HORÁCIO WANDERLEI RODRIGUES que o processualista deve perceber o caráter ético da ciência processual, sob pena de "não se inserir no contexto político, econômico, cultural e social de seu tempo, continuando a ver as questões de acesso à justiça apenas como problemas a serem resolvidos através da criação de novos instrumentos técnico-processuais ou da correção dos existentes, estará auxiliando na manutenção de reprodução do status quo. É preciso que o sistema processual seja visto não somente como um instrumento de solução de conflitos intersubjetivos (aspecto inegavelmente importante) ou mesmo difusos, coletivos ou individuais homogêneos, mas também e fundamentalmente como instrumento político de realização da justiça social, escopo maior do Estado contemporâneo" (cfr. "Acesso à justiça no direito processual brasileiro", Acadêmica, São Paulo, 1994, p. 128, apud BEDAQUE, José Roberto dos Santos. "Os elementos objetivos da demanda examinados à luz do contraditório", in CRUZ E TUCCI, José Rogério (coord.); BEDAQUE José Roberto dos Santos (coord.). "Causa de pedir e pedido no processo civil (questões polêmicas)", RT, São Paulo, 2002, p, nota de rodapé n. 7, pp. 17-18).
} 


\subsection{APELACÃO OU AGRAVO DE INSTRUMENTO?}

A doutrina, de um modo geral, se divide entre os que defendem ser cabível o recurso de agravo de instrumento e aqueles que entendem interponível a apelação.

Os primeiros consideram que haveria maiores benefícios ao sistema se os atos proferidos no curso do procedimento, que, sem encerrá-lo, tivessem por conteúdo alguma das hipóteses do artigo 269, do Código de Processo Civil, não fossem considerados como sentença para fins de recorribilidade. Isto porque enquanto não finalizada a etapa cognitiva, não seria possível a remessa dos autos ao tribunal, consequência inexorável da interposição da apelação, sob pena de se frustrarem os escopos do processo ${ }^{589}$, em plena afronta à própria garantia constitucional da razoável duração do processo ${ }^{590}$.

Nessa linha, somente seriam considerados como sentenças - para fins de interposição de recurso - os provimentos judiciais que esgotassem toda a análise do mérito ou que concluíssem, em relação à integralidade do objeto do processo, pela impossibilidade de seu exame. Tratar-se-ia, assim, de sentenças excepcionalmente recorríveis por agravo de instrumento ${ }^{591}$.

Aduz-se, ainda, que nunca foi exclusividade das sentenças analisar o mérito, nos termos do art. 269, do CPC. Desde antes do advento da Lei n. 11.232/2005 era comum que decisões interlocutórias veiculassem matéria meritória, razão pela qual não há qualquer novidade no manejo do agravo de instrumento ${ }^{592}$.

\footnotetext{
${ }^{589}$ Cfr. SANT'ANNA, Paulo Afonso de Souza. "Sentença parcial", in MEDINA, José Miguel Garcia (coord.); CRUZ, Luana Pedrosa de Figueiredo (coord.); CERQUEIRA, Luiz Otávio Siqueira de (coord.); GOMES JR., Luis Manoel (coord.). Os poderes do juiz e o controle das decisões judiciais: estudos em homenagem à professora Teresa Arruda Alvim Wambier, RT, São Paulo, 2008, pp. 460-461.

${ }^{590} \mathrm{Cfr}$. VARGAS, Jorge de Oliveira. "O novo conceito de sentença e o recurso daquela que não extingue o processo: apelação ou agravo de instrumento?”, in Revista de Processo, n. 148, RT, São Paulo, junho de 2007, p. 116.

${ }^{591}$ Cfr. WAMBIER, Luis Rodrigues; WAMBIER, Teresa Arruda Alvim; MEDINA, José Miguel Garcia. "Breves comentários à nova sistemática processual civil", vol. 2, RT, São Paulo, 2006, pp. 36-38; v. tb. WAMBIER, Teresa Arruda Alvim. "O conteúdo das decisões judiciais como fator determinante para sua classificação e para a indicação dos recursos cabiveis", in Revista de Processo, n. 162, pp. 284-285.

${ }^{592}$ Cfr. MARTINS, Sandro Gilbert. "Reflexos do novo conceito de sentença" (CPC, art. 162, $\S 1^{o}$, com a redação dada pela Lei n. 11.232/2005)", in Revista de Processo, n. 163, RT, São Paulo, setembro de 2008, p. 309.
} 
Não obstante o respeito e a consideração de que é digna a posição supra, com ela não se pode corroborar. É muito mais benéfico ao recorrente utilizar o recurso de apelação:

(i) o recurso é recebido, via de regra, no efeito suspensivo, enquanto o agravo depende de concessão pelo relator no tribunal;

(ii) a sustentação oral é permitida somente no julgamento do recurso de apelação;

(iii) eventual recurso extraordinário ou especial interposto contra a decisão não ficará retido;

(iv) o julgamento da apelação conta com revisor, o que não ocorre no $\operatorname{agravo}^{593}$;

(v) possibilidade de interposição de embargos infringentes contra o acórdão que julga a apelação, embora haja construção jurisprudencial admitindo o expediente excepcionalmente em relação ao agravo de instrumento ${ }^{594}$.

Nessa linha, a interposição de apelação atende melhor ao devido processo legal, em sintonia com o art. $5^{\circ}, \mathrm{LV}$, da Constituição Federal ${ }^{595}$.

Além disso, o prazo para a interposição do agravo de instrumento é consideravelmente menor que o previsto para o manejo da apelação, havendo disparidade, também, em relação ao preço do preparo ${ }^{596}$. Sua interposição não é realizada no primeiro grau de jurisdição, o que inviabiliza o emprego de técnicas de aceleramento do procedimento, como o art. 518, $\S 1^{\circ}$, do Código de Processo Civil, e

\footnotetext{
${ }^{593}$ Cfr. SILVA FILHO, Ricardo de Oliveira. "A sentença parcial de mérito e o processo civil moderno", in Revista da AJURIS, n. 108, AJURIS, Porto Alegre, dezembro de 2007, p. 296.

${ }^{594}$ Cfr. NEVES, Daniel Amorim Assumpção. "O novo conceito de sentença de mérito e os problemas recursais", in BRUSCHI, Gilberto Gomes (coord.); SHIMURA, Sérgio (coord.). Execução civil e cumprimento de sentença, vol. 2, Método, São Paulo, 2007, pp. 80-81.

${ }^{595}$ Cfr. MILMAN, Fabio. "O novo conceito legal de sentença e suas repercussões recursais: primeiras experiências com a apelação por instrumento", in Revista de Processo, n. 150, RT, São Paulo, agosto de 2007.p. 166.

${ }^{596} \mathrm{Cfr}$. SICA, Heitor Vitor Mendonça. "Algumas implicações do novo conceito de sentença, de acordo com a Lei n. 11.232/2005", in CARMONA, Carlos Alberto (coord.). Reflexões sobre a reforma do Código de Processo Civil, Atlas, São Paulo, 2007, p. 203.
} 
retira da parte contrária oportunidade de manifestar eventual inconformismo contra a decisão por meio de interposição adesiva de recurso, incabível em relação ao agravo ${ }^{597}$.

No mais, cria, ao arrepio da lei, nova hipótese de juízo de retratação de sentença, podendo ainda estar sujeito à sua conversão em retido pelo relator, caso entende ausentes os requisitos do art. 522, do Código ${ }^{598}$.

Neste ponto, pertinente observar que o ordenamento jurídico brasileiro contempla como regra a utilização do agravo na modalidade retida, sendo apenas três as hipóteses de cabimento do recurso por meio de instrumento:

(i) decisão do juiz que não recebe recurso de apelação;

(ii) decisão do juiz que define os efeitos em que o recurso

de apelação é recebido;

(iii) decisão capaz de causar à parte lesão grave ou de difícil reparação.

Trata-se de situações em que não é possível à parte aguardar seja a revisão condicionada à subida de recurso interposto ao final, de modo que a lei permite a imediata recorribilidade. Por óbvio, apenas a última delas interessa à recorribilidade da sentença parcial, sendo viável imaginar, portanto, situações em que tal decisão não implicaria situação apta a possibilitar a interposição por meio de instrumento, devendo ser utilizado o agravo retido. Entretanto, tal quadro não se mostra tecnicamente correto, pois não é admissível a interposição de dois recursos diferentes para impugnar atos decisórios de mesma natureza jurídica ${ }^{599}$.

\footnotetext{
${ }^{597}$ Cfr. MARTINS, Renato Castro Teixeira. "Apelação por instrumento", in MEDINA, José Miguel Garcia (coord.); CRUZ, Luana Pedrosa de Figueiredo (coord.); CERQUEIRA, Luiz Otávio Siqueira de (coord.); GOMES JR., Luis Manoel (coord.). Os poderes do juiz e o controle das decisões judiciais: estudos em homenagem à professora Teresa Arruda Alvim Wambier, RT, São Paulo, 2008, pp. 839-840.

${ }^{598} \mathrm{Cfr}$. VARGAS, Jorge de Oliveira. "O novo conceito de sentença e o recurso daquela que não extingue o processo: apelação ou agravo de instrumento?”, in Revista de Processo, n. 148, RT, São Paulo, junho de 2007, p. 116.

599 Sobre o ponto, DANIEl AMORIM AssumpÇÃo NeVEs afirma que "algumas hipóteses de pronunciamento parcial do mérito poderiam ser consideradas como potencialmente danosas e por isso tal decisão seria recorrível por agravo de instrumento. Por outro lado, concluir-se-ia que outras situações não gerariam tais condições, sendo o pronunciamento recorrível por agravo retido. [...] O que se pretende demonstrar é a absoluta falta de técnica de se considerar dois recursos diferentes para decisões de mesmo conteúdo, e pela previsão legal de mesma natureza" (cfr. NEVES, Daniel Amorim Assumpção. "O novo conceito de sentença de mérito e os problemas recursais", in BRUSCHI, Gilberto
} 
Outra potencial consequência deletéria advinda da utilização do agravo de instrumento consiste na impossibilidade de reiteração de eventual agravo retido interposto contra interlocutória envolvendo resolução de questão incidente ligada a parcela do mérito analisada pela sentença parcial.

Imagine-se que o juiz indefira pedido de produção de determinada prova, interpondo a parte interessada agravo retido, e, na sequência, o magistrado profira sentença parcial julgando improcedente a pretensão veiculada. Ora, se admitido o agravo de instrumento contra esta decisão haveria mais um problema procedimental a se resolver, envolvendo o veículo adequado para a reiteração do agravo retido (art. 523 e $\S 1^{\circ}$, do Código) ${ }^{600}$.

A utilização de recurso de agravo de instrumento contra a sentença parcial, além de violar a regra da correspondência, macula o princípio da isonomia, pois trata de forma diferente situações que estão em pé de igualdade, ofendendo, assim, ao art. $5^{\circ}$, caput, da Constituição ${ }^{601}$.

Diante disso, há quem defenda a aplicação integral ao agravo de instrumento das regras atinentes ao processamento e julgamento da apelação, a fim de se manter íntegro o princípio constitucional da isonomia. Formalmente, ter-seia um agravo, mas, na substância, estar-se-ia diante de uma apelação. Assim, deveriam ser admitidos embargos infringentes, sustentação oral, revisor, subida imediata de recursos extraordinários, ação rescisória, etc. ${ }^{602}$.

Gomes (coord.); SHIMURA, Sérgio (coord.). Execução civil e cumprimento de sentença, v. 2, Método, São Paulo, 2007, p. 79).

${ }^{600} \mathrm{Cfr}$. SICA, Heitor Vitor Mendonça. "Algumas implicações do novo conceito de sentença, de acordo com a Lei n. 11.232/2005", in CARMONA, Carlos Alberto (coord.). Reflexões sobre a reforma do Código de Processo Civil, Atlas, São Paulo, 2007, p. 202.

${ }^{601} \mathrm{Cfr}$. VARGAS, Jorge de Oliveira. "O novo conceito de sentença e o recurso daquela que não extingue o processo: apelação ou agravo de instrumento?", in Revista de Processo, n. 148, RT, São Paulo, junho de 2007, pp. 115-116.

${ }^{602}$ Cfr. MITIDIERO, Daniel. "Direito fundamental ao julgamento definitivo da parcela incontroversa: uma proposta de compreensão do art. $273, \S 6^{\circ}, C P C$, na perspectiva do direito fundamental a um processo sem dilações indevidas (art. $5^{\circ}$, LXXVIII, CF/88)", in Revista de Processo, n. 149, p. 116; v. tb. SOUZA JUNIOR, Sidney Pereira de. "Sentenças parciais no processo civil - consequências no âmbito recursal”, Método, São Paulo, 2009, p. 118 e 126-128. 
Ocorre que o manejo do agravo representaria fusão entre os artigos 513 e 522, do Código de Processo Civil, de modo a criar situação na qual o recurso a ser interposto contra a decisão dependeria do momento processual em que ela fosse proferida. Assim, haveria somente a transferência para a seara recursal da dificuldade em se harmonizar os conceitos de sentença e decisão interlocutória ${ }^{603}$.

Há, ainda, os que consideram que o provimento parcial de mérito é sentença, mas que, em razão das especificidades existentes, deve ser interposto agravo de instrumento, mitigando-se o princípio da correspondência ${ }^{604}$. Exemplificando, afirmam que há diversas situações em que a lei traz exceções à correlação, trazendo sentenças recorríveis por agravo de instrumento: (i) a decisão que julga a liquidação de sentença (art. 475-H, do CPC); (ii) a decisão que rejeita, no mérito, a impugnação ao cumprimento de sentença (art. 475-M, § 3, do CPC); (iii) decisão que decreta a falência (artigos 100 e 189, da Lei de Falências) ${ }^{605}$.

Para essa corrente, os princípios, tal qual o da correspondência, incidem em grau variado, a depender da situação concreta. Diferem, portanto, da norma jurídica que tem aplicação imediata e incondicional pelo processo de subsunção dos fatos à norma.

Nesse sentido, com base nas teorias de Alexy e Dworkin, afirma SIDNEY PEREIRA DE SOUZA JÚNIOR que "o princípio da correspondência, não obstante tenha validade e informe a legislação processual civil, vem sofrendo, gradativamente, um processo de enfraquecimento, o que faz com que seja suplantado por outros princípios (v.g.,celeridade e razoável duração do processo) nessas situações concretas de análise do recurso cabível contra sentenças parciais"

${ }^{603}$ Cfr. VAREJÃO, José Ricardo do Nascimento. "As classificações, a lei 11.232/2005 e o 'novo' conceito de sentença", in WAMBIER, Teresa Arruda Alvim (coord.). Aspectos Polêmicos da Nova Execução, 3: de títulos judiciais, Lei 11.232/2005, RT, São Paulo, 2006, p. 389.

${ }^{604}$ Cfr. SOUZA JUNIOR, Sidney Pereira de. "Sentenças parciais no processo civil - consequências no âmbito recursal”, Método, São Paulo, 2009, p. 122.

${ }^{605}$ Cfr. WAMBIER, Teresa Arruda Alvim. "Nulidades do processo e da sentença", 6 a ed., RT, São Paulo, 2007, pp. 35 e 123.

${ }^{606}$ Cfr. SOUZA JUNIOR, Sidney Pereira de. "Sentenças parciais no processo civil - consequências no âmbito recursal”, Método, São Paulo, 2009, pp. 123-125. 
Ora, o legislador previu expressamente na lei a correspondência que deve existir entre os recursos e as decisões judiciais. Dessa forma, embora se considere possível, em tese, eventual mitigação do princípio da correlação na hipótese de conflito com outros princípios, entende-se que tal expediente se mostra desnecessário no caso de sentenças parciais. Nessa linha, é perfeitamente possível se adotar quanto à recorribilidade dessas decisões, solução jurídica compatível com o sistema recursal vigente, sem a necessidade de mitigação de qualquer princípio processual.

No mais, nem se argumente que a existência da sentença parcial ressuscitaria discussão envolvendo a possibilidade de interposição de mais de um recurso contra a mesma decisão.

Suponha-se que o juiz decida questões interlocutórias (v.g., exclusão de litisconsorte com fulcro no art. 267, do CPC ou concessão de tutela antecipada) no corpo do mesmo provimento judicial em que acolhe um dos pedidos deduzidos pelo autor, fracionando o julgamento do mérito. Como o pronunciamento judicial em tela implicou algum dos conteúdos do art. 269, do Código, somente é possível classificá-lo como sentença - parcial, no caso, pois não apreciada integralmente a matéria deduzida em juízo - dotada de diferentes capítulos.

Assim, ainda que haja diferentes capítulos tratando de matérias de natureza diversa, todos eles serão impugnáveis por um único recurso: apelação. A solução proporcionada pela teoria dos capítulos da sentença resolve plenamente o problema ${ }^{607}$.

Ora, a simplista negativa de existência de uma sentença parcial de mérito, classificando-a como interlocutória com objetivo único de afastar o cabimento do recurso de apelação, não enfrenta a situação de forma adequada, visto que deixa sem resposta problemas que não podem ser ignorados ${ }^{608}$.

${ }^{607}$ Cfr. DINAMARCO, Cândido Rangel. "Instituições de direito processual civil", $5^{\mathrm{a}}$ ed., Malheiros Editores, São Paulo, 2005, pp. 665-670.

${ }^{608}$ Não se pode admitir a referida conclusão simplista. Atribuir tratamento diferente a situações substancialmente idênticas, tão-somente para afastar a interposição de apelação contra a decisão parcial de mérito cria mais problemas que soluções (cfr. NEVES, Daniel Amorim Assumpção. "O novo conceito 
Dúvida não há de que de sentença cabe apelação ${ }^{609}$, devendo os operadores do direito buscar as compatibilizações necessárias à extração da maior dose de efetividade possível do instrumento estatal.

\section{3. ÓBICES PROCEDIMENTAIS E POSSÍVEIS SOLUCÕES}

Estabelecida a apelação como o recurso adequado para impugnação das sentenças interlocutórias, cumpre examinar as propostas destinadas a eliminar os problemas procedimentais verificados, elegendo-se, ao final, a técnica que representar maior ganho em termos de efetividade processual.

Há, em síntese, dois posicionamentos acerca da melhor forma de se processar a apelação contra a sentença parcial:

(i) a formação de um instrumento, com cópia das peças necessárias à cognição da matéria pelo tribunal ${ }^{610}$;

\footnotetext{
de sentença de mérito e os problemas recursais", in BRUSCHI, Gilberto Gomes (coord.); SHIMURA, Sérgio (coord.). Execução civil e cumprimento de sentença, v. 2, Método, São Paulo, 2007, p. 81).

${ }^{609}$ Nesse sentido, é importante observar que o próprio art. 513 do CPC, ao prever o cabimento de apelação contra sentenças, faz referência expressa, entre parênteses, aos mesmos dispositivos constantes no art. 162, § 1": "artigos 267 e 269" (cfr. SICA, Heitor Vitor Mendonça. "Algumas implicações do novo conceito de sentença, de acordo com a Lei n. 11.232/2005", in CARMONA, Carlos Alberto (coord.). Reflexões sobre a reforma do Código de Processo Civil, Atlas, São Paulo, 2007, pp. 186-209, p. 201).

${ }^{610}$ Cfr. OLIVEIRA, Bruno Silveira de. "Um novo conceito de sentença?" in Revista de Processo, n. 149, RT, São Paulo, julho de 2007, p. 133; BUENO, Cássio Scarpinella. "A nova etapa da reforma do Código de Processo Civil: comentários sistemáticos às Leis n. 11.187, de 19-10-2005, e 11.232, de 22-12-2005", v. 1, Saraiva, São Paulo, 2006; TESHEINER, José Maria Rosa. "Nova sistemática processual civil", $2^{\mathrm{a}}$ ed., Plenum, Caxias do Sul, 2006; OLIANI, José Alexandre Manzano. "Cumprimento da sentença interlocutória que condena ao pagamento de soma, de acordo com a Lei 11.232/05", in SANTOS, Ernane Fidélis (coord.); WAMBIER, Luiz Rodrigues (coord.); NERY JR., Nelson (coord.); WAMBIER, Teresa Arruda Alvim (coord.). Execução civil: estudos em homenagem ao professor Humberto Theodoro Júnior, RT, São Paulo, 2007; CORTEZ, Cláudia Helena Poggio. "O novo conceito de sentença visto pelos tribunais", in Revista de Processo, n. 171, RT, São Paulo, maio de 2009; VARGAS, Jorge de Oliveira. "O novo conceito de sentença e o recurso daquela que não extingue o processo: apelação ou agravo de instrumento?", in Revista de Processo, n. 148, RT, São Paulo, junho de 2007; THEODORO JUNIOR, Humberto. "As novas reformas do Código de Processo Civil", Forense, Rio de Janeiro, 2006; MARTINS, Renato Castro Teixeira. "Apelação por instrumento", in MEDINA, José Miguel Garcia (coord.); CRUZ, Luana Pedrosa de Figueiredo (coord.); CERQUEIRA, Luiz Otávio Siqueira de (coord.); GOMES JR., Luis Manoel (coord.). Os poderes do juiz e o controle das decisões judiciais: estudos em homenagem à professora Teresa Arruda Alvim Wambier, RT, São Paulo, 2008; MILMAN, Fabio. " $O$ novo conceito legal de sentença e suas repercussões recursais: primeiras experiências com a apelação por instrumento", in Revista de Processo, n. 150, RT, São Paulo, agosto de 2007.
} 
(ii) a formação de autos suplementares, nos quais haveria o prosseguimento do processo em primeiro grau de jurisdição para julgamento da parcelo do mérito ainda não analisada ${ }^{611}$.

A primeira corrente considera que, como não houve encerramento da fase cognitiva por meio da sentença parcial, de modo que o processo prossegue em relação à parcela da demanda ainda não julgada, não é possível que os autos sejam remetidos à instância superior de imediato ${ }^{612}$.

Dessa forma, o recurso de apelação deve ser processado em autos apartados ${ }^{613}$, devidamente instruídos com as cópias suficientes à compreensão da matéria objeto de inconformismo ${ }^{614}$.

Com a utilização da apelação por instrumento estaria plenamente respeitado o princípio da isonomia ${ }^{615}$, visto que a parte não se sujeitaria a um trâmite recursal diferente unicamente em razão do momento processual em que a decisão foi prolatada ${ }^{616}$.

${ }^{611}$ Cfr. DIDIER JR., Fredie. "Inovações na antecipação dos efeitos da tutela e a resolução parcial do mérito", in Revista de Processo, n. 110, RT, São Paulo, abril-junho de 2003; NEVES, Daniel Amorim Assumpção. "O novo conceito de sentença de mérito e os problemas recursais", in BRUSCHI, Gilberto Gomes (coord.); SHIMURA, Sérgio (coord.). Execução civil e cumprimento de sentença, v. 2, Método, São Paulo, 2007; REDONDO, Bruno Garcia. "Sentença parcial de mérito e apelação em autos suplementares", in Revista de Processo, n. 160, RT, São Paulo, junho de 2008; SILVA FILHO, Ricardo de Oliveira. "A sentença parcial de mérito e o processo civil moderno", in Revista da AJURIS, n. 108, AJURIS, Porto Alegre, dezembro de 2007; SICA, Heitor Vitor Mendonça. "Algumas implicações do novo conceito de sentença, de acordo com a Lei n. 11.232/2005", in CARMONA, Carlos Alberto (coord.). Reflexões sobre a reforma do Código de Processo Civil, Atlas, São Paulo, 2007.

${ }^{612}$ Trata-se de uma das preocupações apontadas por BRUNO SILVEIRA DE OlIVEIRA: "Ficamos, então com três certezas: (i) o conceito de sentença mudou; (ii) da sentença cabe apelação [art. 513]; (iii) a apelação interposta de sentença que julgar um dos capítulos da demanda não pode subir nos próprios autos do processo" (cfr. "Um novo conceito de sentença?" in Revista de Processo, n. 149, RT, São Paulo, julho de 2007, p. 133).

${ }_{613}$ Cfr. BUENO, Cássio Scarpinella. "A nova etapa da reforma do Código de Processo Civil: comentários sistemáticos às Leis n. 11.187, de 19-10-2005, e 11.232, de 22-12-2005”, v. 1, Saraiva, São Paulo, 2006, p. 20.

${ }^{614}$ Cfr. TESHEINER, José Maria Rosa. "Nova sistemática processual civil", $2^{\mathrm{a}}$ ed., Plenum, Caxias do Sul, 2006, p. 44.

${ }^{615}$ Cfr. OLIANI, José Alexandre Manzano. "Cumprimento da sentença interlocutória que condena ao pagamento de soma, de acordo com a Lei 11.232/05", in SANTOS, Ernane Fidélis (coord.); WAMBIER, Luiz Rodrigues (coord.); NERY JR., Nelson (coord.); WAMBIER, Teresa Arruda Alvim (coord.). Execução civil: estudos em homenagem ao professor Humberto Theodoro Júnior, RT, São Paulo, 2007, nota de rodapé n. 19, p. 181.

${ }^{616}$ Cfr. CORTEZ, Cláudia Helena Poggio. "O novo conceito de sentença visto pelos tribunais", in Revista de Processo, n. 171, RT, São Paulo, maio de 2009, pp. 290-291. 
Ademais, se admitido o agravo de instrumento seria necessário que se modificasse seu rito de julgamento, passando-se a permitir revisão, sustentação oral e embargos infringentes ${ }^{617}$, a fim de se resguardar o direito ao contraditório e à ampla defesa $^{618}$.

Sendo assim, além de obedecer à regra da correspondência, tal saída atenderia de forma mais satisfatória ao devido processo legal $^{619}$.

Afirma-se, ainda, que o processamento por instrumento da apelação não representaria criação de recurso novo, não havendo se falar em violação ao princípio da taxatividade ${ }^{620}$. Desnecessária seria, portanto, qualquer modificação legislativa, bastando a aplicação analógica das regras referentes ao agravo de instrumento $^{621}$.

Nesse sentido, o processamento por instrumento seguiria o mesmo procedimento da apelação contra sentença final, com a única peculiaridade de que, após realizado o primeiro juízo de admissibilidade do recurso e colhidas as contrarrazões, seria efetuada a remessa do recurso em autos separados ${ }^{622}$.

${ }^{617}$ Cfr. DIDIER JR., Fredie. "Inovações na antecipação dos efeitos da tutela e a resolução parcial do mérito", in Revista de Processo, n. 110, RT, São Paulo, abril-junho de 2003, p. 240; v. tb. MARTINS, Sandro Gilbert. "Reflexos do novo conceito de sentença (CPC, art. 162, § $1^{\circ}$, com a redação dada pela Lei n. 11.232/2005)", in Revista de Processo, n. 163, RT, São Paulo, setembro de 2008, p. 309.

${ }^{618}$ TERESA ARRUDA ALVIM WAMBIER, inicialmente, era favorável à impugnação da sentença parcial por meio de agravo de instrumento com efeito suspensivo. Entretanto, após maior reflexão, concluiu que a apelação por instrumento seria mais adequada, pois "essa é a solução que realmente preserva o Princípio da Isonomia, o Princípio da Isonomia no sentido amplíssimo, quer dizer, a parte não pode ter uma solução diferente com relação ao pedido que foi decidido precocemente e ao pedido que vai ser decidido depois. Porque se houver um agravo de instrumento com efeito suspensivo, a parte vai ficar privada da revisão, vai ficar privada de fazer sustentação oral, o recurso não é o mesmo" (cfr. WAMBIER, Teresa Arruda Alvim. "O agravo e o conceito de sentença", in Revista de Processo, n. 144, RT, São Paulo, fev/2007, p. 252).

${ }^{619} \mathrm{Cfr}$. VARGAS, Jorge de Oliveira. "O novo conceito de sentença e o recurso daquela que não extingue o processo: apelação ou agravo de instrumento?", in Revista de Processo, n. 148, RT, São Paulo, junho de 2007, p. 117.

${ }^{620}$ Cfr. THEODORO JUNIOR, Humberto. "As novas reformas do Código de Processo Civil", Forense, Rio de Janeiro, 2006, pp. 52-53.

${ }^{621}$ Cfr. MARTINS, Renato Castro Teixeira. "Apelação por instrumento", in MEDINA, José Miguel Garcia (coord.); CRUZ, Luana Pedrosa de Figueiredo (coord.); CERQUEIRA, Luiz Otávio Siqueira de (coord.); GOMES JR., Luis Manoel (coord.). Os poderes do juiz e o controle das decisões judiciais: estudos em homenagem à professora Teresa Arruda Alvim Wambier, RT, São Paulo, 2008, p. 842.

${ }^{622}$ Cfr. MILMAN, Fabio. "O novo conceito legal de sentença e suas repercussões recursais: primeiras experiências com a apelação por instrumento", in Revista de Processo, n. 150, RT, São Paulo, agosto de 2007, p. 169. 
Observe-se, no mais, que não há nenhum artigo de lei que determine a subida da apelação nos próprios autos do processo, expediente realizado somente em respeito à força da tradição ${ }^{623-624}$.

De outro lado, a solução alternativa consiste na formação de autos suplementares ${ }^{625}$. Tal seria mais adequada porque a interposição da apelação por instrumento mostrar-se-ia como medida de lege ferend ${ }^{626}$, por implicar violação ao princípio da taxatividade e da tipicidade dos recursos, de modo que os aplicadores do direito não poderiam inovar, criando modalidade recursal não prevista em lei federal ${ }^{627}$. Para o manejo da apelação por instrumento não se poderia prescindir de reforma legislativa prevendo expressamente tal mecanismo ${ }^{628}$.

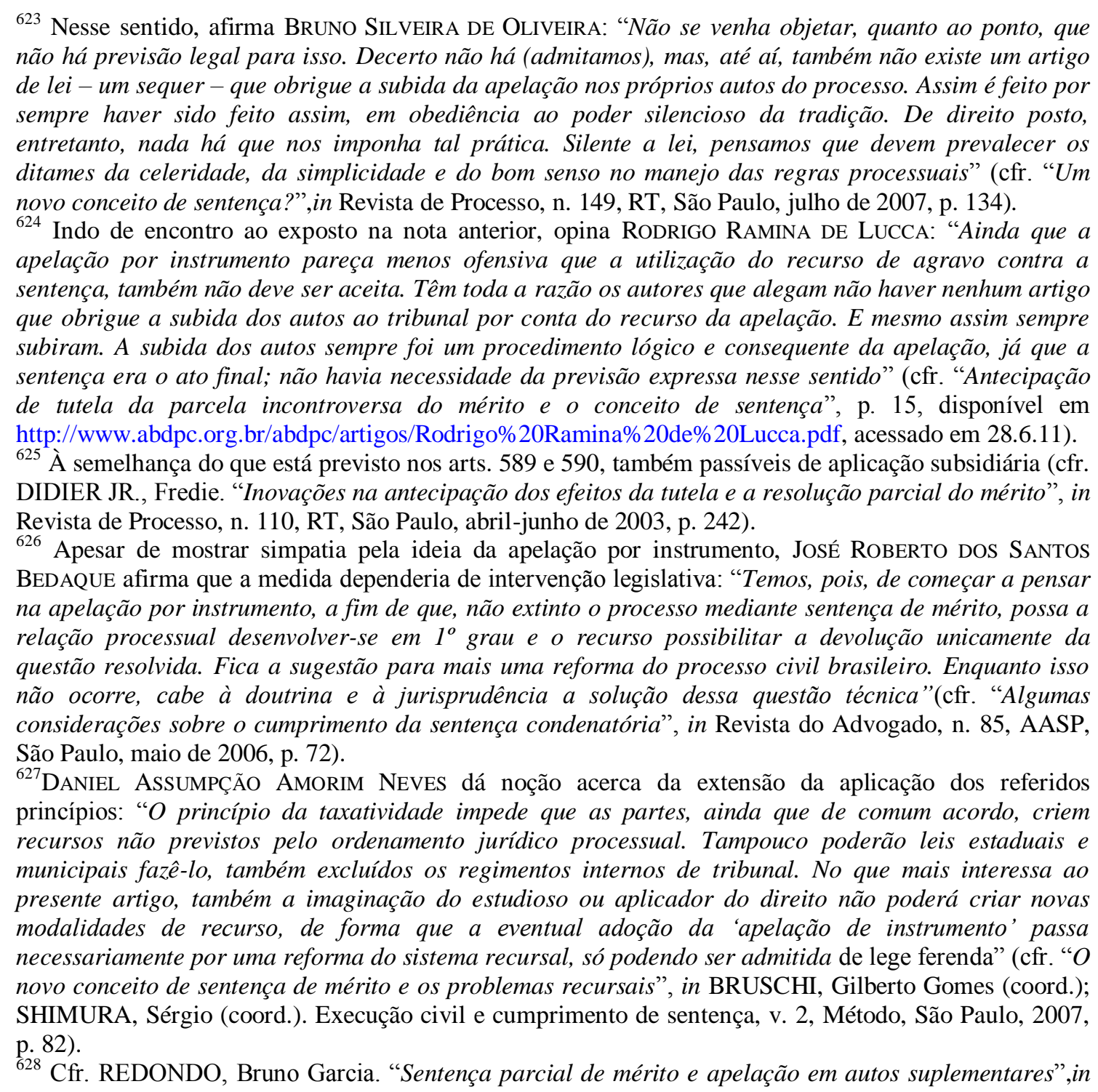
Revista de Processo, n. 160, RT, São Paulo, junho de 2008, p. 152; v. tb. SOUZA JUNIOR, Sidney 
Sendo assim, a formação de autos suplementares consubstanciar-se-ia na hipótese menos traumática ao sistema, visto que permaneceriam em primeiro grau de jurisdição, propiciando o julgamento da parcela do mérito ainda não analisada ${ }^{629}$, e viabilizando o imediato exame do apelo contra a sentença parcial pelo tribunal.

Nessa linha, seria de responsabilidade da parte interessada a correta formação dos autos suplementares, incidindo, na espécie, o art. 365, IV, do Código de Processo Civil, quanto à autenticidade das cópias extraídas ${ }^{630}$.

Dessa forma, criar-se-ia instrumento semelhante a uma "carta de sentença", permitindo o prosseguimento da fase cognitiva do processo, em relação ao que não foi abordado na sentença parcial, enquanto os autos originais subiriam ao segundo grau para exame da apelação interposta, à semelhança do que, corriqueiramente, ocorre com a execução provisória, na hipótese de interposição de apelo sem efeito suspensivo ${ }^{631}$.

Sobre o ponto, CÂNDIDO RANGEl DinAMARCO ensina que "Não há dificuldade prática para que assim se faça, porque um dos dois processos utilizará os autos principais e o outro, cópias a serem extraídas daqueles. A jurisprudência vem preferindo que nos autos principais flua o processo de execução e

Pereira de. "Sentenças parciais no processo civil - consequências no âmbito recursal", Método, São Paulo, 2009, pp. 133-138.

${ }^{629}$ Cfr. SILVA FILHO, Ricardo de Oliveira. "A sentença parcial de mérito e o processo civil moderno", in Revista da AJURIS, n. 108, AJURIS, Porto Alegre, dezembro de 2007, p. 296; v. tb. GONÇALVES FILHO, João Gilberto. "O princípio constitucional da eficiência no processo civil". 2010. Tese (Doutorado em Direito Processual) - Faculdade de Direito, Universidade de São Paulo, São Paulo, 2010. Disponível em: <http://www.teses.usp.br/teses/disponiveis/2/2137/tde-17112011-085839/>. Acesso em: 2012-07-03, p. 298.

${ }^{630}$ Cfr. NEVES, Daniel Amorim Assumpção. "O novo conceito de sentença de mérito e os problemas recursais", in BRUSCHI, Gilberto Gomes (coord.); SHIMURA, Sérgio (coord.). Execução civil e cumprimento de sentença, v. 2, Método, São Paulo, 2007, pp. 82-83.

Neste ponto cumpre anotar que o autor em um primeiro momento considerava interponível contra a sentença parcial o agravo de instrumento, tendo corretamente alterado seu entendimento (cfr. NEVES, Daniel Amorim Assumpção. "O novo conceito de sentença", in Reforma do CPC: leis 11.187/2005, 11.232/2005, 11.276/2006, 11.276/2006 e 11.280/2006, RT, São Paulo, 2006, pp. 84-85).

${ }^{631} \mathrm{Cfr}$. SICA, Heitor Vitor Mendonça. "Algumas implicações do novo conceito de sentença, de acordo com a Lei n. 11.232/2005", in CARMONA, Carlos Alberto (coord.). Reflexões sobre a reforma do Código de Processo Civil, Atlas, São Paulo, 2007, p. 205. 
na carta de sentença (hoje, meras cópias) a liquidação, mas o contrário também conduziria ao mesmo efeito" ${ }^{\text {,632. }}$.

Com efeito, não há nenhum dispositivo legal que impeça essa solução, de modo que sua adoção se impõe por força do princípio da eficiência ${ }^{633}$. Trata-se, portanto, de mecanismo compatível com o atual sistema recursal, capaz de garantir todas as vantagens da impugnação da sentença parcial por apelação por instrumento (v.g., efeito suspensivo, prazo, preparo, possibilidade de reiteração de agravos retidos, revisão, sustentação oral, interposição de embargos infringente), sem a desvantagem da discussão acerca da necessidade de intervenção legislativa.

O que se conclui dessa análise é que as técnicas do julgamento fracionado do mérito e da sentença parcial são repelidas pela doutrina unicamente por conta das dificuldades procedimentais que acarretam no plano recursal.

Ora, tanto é que, para se verificar a extrema e inegável utilidade do emprego destes mecanismos, basta imaginar um cenário em que tais problemas materiais não existam, como o propiciado pelo processo eletrônico. Nessa situação hipotética a interposição de recurso contra a sentença parcial seria realizada de forma muito simples, com o envio de cópia digital das peças processuais ao tribunal ${ }^{634}$.

Diante disso, é evidente que dificuldades práticas não podem servir de óbice a inviabilizar ferramentas processuais capazes de conferir significativa efetividade ao método estatal de resolução de conflitos, devendo os processualistas realizar, à luz do ordenamento vigente, as adaptações procedimentais necessárias.

\footnotetext{
${ }^{632}$ Cfr. "Capítulos de sentença", $4^{\mathrm{a}}$ ed., Malheiros, São Paulo, 2009, p. 127).

${ }^{633}$ Cfr. GONÇALVES FILHO, João Gilberto. "O princípio constitucional da eficiência no processo civil". 2010. Tese (Doutorado em Direito Processual) - Faculdade de Direito, Universidade de São Paulo, São Paulo, 2010. Disponível em: <http://www.teses.usp.br/teses/disponiveis/2/2137/tde-17112011085839/>. Acesso em: 2012-07-03, p. 299.

${ }^{634}$ Cfr. SCARPARO, Eduardo Kochenborger. "Sentenças parciais? Considerações a partir da reforma do art. 162, $\S 1^{\circ}$, do Código de Processo Civil", p. 16, disponível em http://www.scarparo.adv.br/artigos/sent.pdf, acessado em 6.6.11.
} 


\subsection{APLICACÃO DO PRINCÍPIO DA FUNGIBILIDADE RECURSAL}

Do exposto no item anterior, verifica-se haver grande discussão doutrinária acerca da adequada interposição de recursos contra as sentenças parciais de mérito.

Nesse contexto, ganha importante relevo a incidência do princípio da fungibilidade, o qual tem estreita relação com o requisito de admissibilidade recursal denominado cabimento. Esse requisito, segundo BARBOSA MOREIRA, é formado por dois aspectos complementares: “ $o$ da recorribilidade $d a$ decisão e o da propriedade do recurso interposto. Para ensejar o juízo positivo de admissibilidade, além de ser obviamente necessário que a decisão comporte algum recurso, cumpre o recurso interposto coincida com aquele que a lei aponta como o adequado ao caso" ${ }^{, 635}$.

Embora inexistam dúvidas acerca da recorribilidade do ato decisório em tela, o novo conceito de sentença suscitou grandes divergências acerca da correta identificação dos provimentos judiciais e, consequentemente, da propriedade ou adequação dos recursos contra eles interponíveis, se apelação ou agravo de instrumento ${ }^{636}$.

A confusão existente foi gerada pela omissão e pela ambiguidade do legislador na promoção da reforma, não sendo possível atribuí-la às partes $^{637}$.

\footnotetext{
${ }^{635} \mathrm{Cfr}$. BARBOSA MOREIRA, José Carlos. "Juízo de admissibilidade no sistema dos recursos civis", Borsói, Rio de Janeiro, 1968, p. 47.

${ }^{636}$ Cfr. SOUZA JUNIOR, Sidney Pereira de. "Sentenças parciais no processo civil - consequências no âmbito recursal”, Método, São Paulo, 2009, p. 142.

${ }^{637}$ Cfr. NEVES, Daniel Amorim Assumpção. "O novo conceito de sentença de mérito e os problemas recursais", in BRUSCHI, Gilberto Gomes (coord.); SHIMURA, Sérgio (coord.). Execução civil e cumprimento de sentença, v. 2, Método, São Paulo, 2007, p. 85; v. tb. VARGAS, Jorge de Oliveira. " $O$ novo conceito de sentença e o recurso daquela que não extingue o processo: apelação ou agravo de instrumento?", in Revista de Processo, n. 148, RT, São Paulo, junho de 2007, p. 117.
} 
A ideia de que a parte não poderia ser prejudicada por erro do tribunal deu origem, na Alemanha, ao princípio do recurso indiferente (SowohlalsauchTheorie). Essa concepção prevaleceu sobre a teoria objetiva, pela qual o recurso correto seria aquele adequado ao aspecto intrínseco da decisão, bem como sobre a subjetiva, segundo a qual o recurso cabível seria aquele considerado correto pelo tribunal $^{638}$.

Construiu-se, então, o princípio do maior favor (Grundsatz der Meistbegünstigung), segundo o qual não é aceitável, em qualquer hipótese, que a parte venha a ser prejudicada por erro do Judiciário. Nessa linha, se o magistrado de forma errônea chama de decisão interlocutória um provimento que, na verdade, é sentença, não se pode apenar a parte por ter interposto agravo de instrumento no lugar de apelação. Transportando essa ideia ao Direito Brasileiro, deve-se entender que sua aplicação não se limita a provimentos judiciais, alcançando também situações geradas pelo sistema, pela lei, que, da mesma forma, não podem prejudicar o recorrente ${ }^{639}$.

Assim, se a parte não pode ser prejudicada por situação de indefinição a que não deu causa, deve ser aplicado o princípio da fungibilidade - antes previsto no art. 810, do Código de Processo Civil de 1939, mas ainda vigente entre nós, implicitamente ${ }^{640}$.

O legislador de 1973 abandou a adoção expressa do princípio da fungibilidade, pois, diante da então perfeita correspondência prevista entre decisão judicial e recurso cabível, considerou que não haveria qualquer dúvida a respeito do cabimento de recursos ${ }^{641}$.

\footnotetext{
${ }^{638}$ Cfr. WAMBIER, Teresa Arruda Alvim. "Os agravos no CPC brasileiro", $4^{\mathrm{a}}$ ed., RT, São Paulo, 2006, p. 172.

${ }^{639}$ Cfr. WAMBIER, Teresa Arruda Alvim. "Os agravos no CPC brasileiro", $4^{\mathrm{a}}$ ed., RT, São Paulo, 2006, pp. 172-173.

${ }^{640}$ Cfr. REDONDO, Bruno Garcia. "Sentença parcial de mérito e apelação em autos suplementares",in Revista de Processo, n. 160, RT, São Paulo, junho de 2008, p. 154; v. tb. WAMBIER, Teresa Arruda Alvim. "Os agravos no CPC brasileiro", $4^{\mathrm{a}}$ ed., RT, São Paulo, 2006, p. 158.

${ }^{641}$ Cfr. NEVES, Daniel Amorim Assumpção. "O novo conceito de sentença de mérito e os problemas recursais", in BRUSCHI, Gilberto Gomes (coord.); SHIMURA, Sérgio (coord.). Execução civil e cumprimento de sentença, v. 2, Método, São Paulo, 2007, p. 84; v. tb. WAMBIER, Teresa Arruda Alvim. "Os agravos no CPC brasileiro", $4^{\mathrm{a}}$ ed., RT, São Paulo, 2006, p. 159.
} 
Entretanto, a certeza visada nunca foi alcançada, tendo surgido diversas questões duvidosas que foram solucionadas satisfatoriamente pela doutrina e pela jurisprudência ${ }^{642}$.

De todo modo, não obstante não haja regra expressa, a existência da fungibilidade, no sistema processual vigente, decorre do art. 250, do Código de $1973^{643}$. Trata-se de disposição ampla e abrangente relacionada ao princípio da instrumentalidade das formas, do qual a fungibilidade é expressão no tocante ao âmbito recursal. Nessa linha, as formas não são fins em si mesmas, mas, sim, veículos para se alcançar determinados objetivos; caso esses tenham sido alcançados, eventual irregularidade formal torna-se irrelevante ${ }^{644}$.

Além da instrumentalidade, a fungibilidade é ligada aos seguintes princípios processuais:

(i) não há nulidade sem prejuízo;

(ii) conservação ou aproveitamento, pelo qual as atividades dos órgãos públicos não devem, na medida do possível, ser desperdiçadas;

(iii) busca da verdade, visto que a maior participação dos sujeitos processuais proporciona um melhor material de cognição ao juiz ${ }^{645}$.

Destarte, se há situação apta a ensejar a incidência do princípio da fungibilidade, essa deve ser admitida, caso não haja qualquer prejuízo às partes, como medida de aproveitamento de atos processuais úteis e de efetividade processual, na busca da melhor solução ao litígio.

\footnotetext{
${ }^{642}$ Exemplo: exclusão de litisconsorte, para a qual se definiu o recurso cabível como sendo o de agravo de instrumento (cfr. DINAMARCO, Cândido Rangel. "Instituições de direito processual civil", v. II, p. 352; v. tb. WAMBIER, Teresa Arruda Alvim. "Os agravos no CPC brasileiro", 4" ed., RT, São Paulo, 2006, p. 192).

${ }^{643}$ Cfr. SOUZA JUNIOR, Sidney Pereira de. "Sentenças parciais no processo civil - consequências no âmbito recursal", Método, São Paulo, 2009, p. 139.

${ }^{644}$ Cfr. WAMBIER, Teresa Arruda Alvim. "Os agravos no CPC brasileiro", $4^{\mathrm{a}}$ ed., RT, São Paulo, 2006, p. 163.

${ }^{645}$ Cfr. WAMBIER, Teresa Arruda Alvim. "Os agravos no CPC brasileiro", $4^{\mathrm{a}}$ ed., RT, São Paulo, 2006, pp. 173-174.
} 
Assim, diante da insegurança jurídica gerada pela indefinição na classificação das decisões e, consequentemente, no recurso cabível, mostra-se necessária a incidência do princípio da fungibilidade ${ }^{646}$. Não aplicá-lo representaria grave violação ao direito de acesso à justiça ${ }^{647}$.

Aliás, em meio ao turbilhão de interpretações díspares ensejadas pela reforma, o único ponto em que a doutrina mostra-se - praticamente unânime $e^{648}$ é justamente quanto à necessidade de aplicação do princípio da fungibilidade recursal ${ }^{649}$. Resta analisar quais os requisitos necessários a tanto, sendo certo que a competência para sua análise é do órgão jurisdicional competente para realizar o juízo de admissibilidade do recurso interposto, já que sua incidência tem efeitos justamente sobre o cabimento, requisito de admissibilidade recursal ${ }^{650}$.

O Código de Processo Civil de 1939 trazia em seu art. 810, dois requisitos negativos para a incidência da fungibilidade recursal: ausência de (i) má-fé; e de (ii) erro grosseiro ${ }^{651}$.

Quanto ao "erro grosseiro", é identificado numa situação que justifique a dúvida acerca do recurso cabível, normalmente, quando doutrina e/ou

\footnotetext{
${ }^{646}$ Cfr. CORTEZ, Cláudia Helena Poggio. "O novo conceito de sentença visto pelos tribunais", in Revista de Processo n. 171, RT, São Paulo, maio/2009, p. 286.

${ }^{647}$ Cfr. CORTEZ, Cláudia Helena Poggio. "O novo conceito de sentença visto pelos tribunais", in Revista de Processo n. 171, RT, São Paulo, maio/2009, pp. 295-296.

${ }^{648}$ Divergindo da corrente amplamente majoritária, GElson AMARO DE SOUZA e RAFAEl José NADIMLAZARI afirmam que não é cabido o "clamor" pela incidência do princípio da fungibilidade recursal ao caso em estudo. A interposição de "apelação por instrumento" implicaria erro grosseiro, tendo alto potencial de ser utilizado como chicana jurídica, em razão da diversidade dos prazos de interposição de apelação e agravo. Além disso, não haveria sequer a possibilidade de sentenças parciais, visto que o critério do conteúdo não é o adequado à classificação dos atos judiciais (cfr. "Breves apontamentos sobre a apelação por instrumento", disponível em http://www.abdpc.org.br/abdpc/artigos/Breves\%20Apontamentos\%20sobre\%20a\%20Apela\%C3\%A7\%C $3 \%$ A3o\% 20por\%20Instrumento\%20-

\%20Rafael\%20Jos\%C3\%A9\%20Nadim\%20de\%20LAZARI\%20e\%20Gelson\%20Amaro\%20de\%20SO UZA.pdf, acessado em 28.6.11, p 14).

${ }^{649}$ Cfr. OLIVEIRA, Bruno Silveira de. "Um novo conceito de sentença?”, in Revista de Processo, n. 149, RT, São Paulo, julho de 2007, p. 135.

${ }^{650}$ Cfr. WAMBIER, Teresa Arruda Alvim. "Os agravos no CPC brasileiro", $4^{\mathrm{a}}$ ed., RT, São Paulo, 2006, p. 179.

${ }^{651}$ Art. 810. Salvo a hipótese de má-fé ou erro grosseiro, a parte não será prejudicada pela interposição de um recurso por outro, devendo os autos ser enviados à Câmara, ou turma, a que competir o julgamento.
} 
jurisprudência apresentassem significativa divergência em relação ao instrumento adequado à veiculação da insurgência ${ }^{652}$.

Nessa linha, a escolha equivocada do meio processual deve ser justificável. É a hipótese em que não há dúvida acerca da modalidade recursal cabível ${ }^{653}$. Destarte, há duas situações em que se pode considerar como "erro grosseiro" a opção da parte por um ou outro recurso: (i) manifesta contrariedade com as regras e princípios processuais vigentes; (ii) unanimidade da doutrina e da jurisprudência quanto ao cabimento apenas do outro recurso, não escolhido pela parte ${ }^{654}$.

Embora corrente sob a égide do CPC39, a concepção de "erro grosseiro" evoluiu para a ideia de dúvida objetiva, identificada na sensível divergência existente em âmbito doutrinário e jurisprudencial acerca do meio adequado $^{655}$. Também, com o Código de 1973, a fungibilidade não mais se limita à seara recursal, aplicando-se a todos os meios processuais ${ }^{656}$.

Por sua vez, em relação à má-fé, a jurisprudência passou a identificar sua ausência na necessidade de atendimento, no recurso interposto pela parte, dos requisitos daquele tido como certo pelo julgador, notadamente quanto ao prazo de interposição ${ }^{657}$.

\footnotetext{
${ }^{652}$ Cfr. OLIVEIRA, Guilherme Peres de. "Novo conceito de sentença: análise da jurisprudência acerca do recurso cabivel nas situações duvidosas e aplicação do princípio da fungibilidade", in Revista de Processo, n. 164, RT, São Paulo, out./2008, p. 304.

${ }^{653}$ Cfr. SICA, Heitor Vitor Mendonça. "Algumas implicações do novo conceito de sentença, de acordo com a Lei n. 11.232/2005", in CARMONA, Carlos Alberto (coord.). Reflexões sobre a reforma do Código de Processo Civil, Atlas, São Paulo, 2007, p. 206.

${ }^{654}$ Cfr. WAMBIER, Teresa Arruda Alvim. "Os agravos no CPC brasileiro", $4^{\mathrm{a}}$ ed., RT, São Paulo, 2006, p. 167.

${ }^{655}$ Cfr. SOUZA JUNIOR, Sidney Pereira de. "Sentenças parciais no processo civil - consequências no âmbito recursal”, Método, São Paulo, 2009, pp. 140-141.

${ }^{656}$ Cfr. OLIVEIRA, Guilherme Peres de. "Novo conceito de sentença: análise da jurisprudência acerca do recurso cabivel nas situações duvidosas e aplicação do princípio da fungibilidade", in Revista de Processo, n. 164, RT, São Paulo, out./2008, p. 304.

${ }^{657}$ Cfr. OLIVEIRA, Guilherme Peres de. "Novo conceito de sentença: análise da jurisprudência acerca do recurso cabivel nas situações duvidosas e aplicação do princípio da fungibilidade", in Revista de Processo, n. 164, RT, São Paulo, out./2008, p. 304.
} 
Contudo, esse entendimento sempre foi muito criticado pela doutrina, visto que, se há desacordo entre os especialistas acerca do recurso cabível, não é possível que se carreiem à parte quaisquer ônus daí decorrentes ${ }^{658}$.

Nessa linha, estritamente relacionada à suposta necessidade de observação do menor prazo como indicador de ausência de má-fé, também se entendia que o recurso tido por inadequado deveria ser passível de conversão no correto e, então, seguir seu procedimento. Trata-se da "conversibilidade formal", sendo que a sua impossibilidade ensejaria o não conhecimento do recurso ${ }^{659}$.

Entretanto, à luz da moderna ciência processual, não há se falar em necessidade de conversão do recurso para que incida o princípio da fungibilidade. O Judiciário deve aceitar uma medida por outra, sem que se proceda a qualquer conversão, desde que o meio eleito pelo recorrente seja apto a alcançar os fins pretendidos $^{660}$.

O pedido da parte deve ser analisado e aceito o meio por ela escolhido, independente da conversão deste naquele tido como correto pelo julgador $^{661}$. Ademais, o recebimento de um recurso por outro (sem que haja conversão), acaba por eliminar a discussão acerca da necessidade de observação do maior prazo

\footnotetext{
${ }^{658}$ BARBOSA MOREIRA, já há muito tempo, demonstrava não ser possível exigir do recorrente que, na dúvida, interponha o recurso que entender adequado, mas no prazo menor. Ensina o processualista carioca, ainda quando vigente o CPC de 1939: "Não nos parece lógico o raciocínio: o recorrente de boafé, sinceramente convencido de que dispõe da apelação, não tem porque sacrificar dois terços do seu prazo, para interpô-la no quinquídio do agravo. Quem o faz é que denota, pelo menos, dúvida quanto ao recurso cabível. A orientação prevalecente, assim, não merece aplauso. Argumenta-se em seu favor com a necessidade de respeitar a coisa julgada: se o recurso cabivel só podia interpor-se em cinco dias e a interposição do outro se deu após o quinto, a decisão recorrida já transitara em julgado. Tudo isso seria exato se não houvesse o art. 810, categórico em afirmar que 'a parte não será prejudicada pela interposição de um recurso pelo outro', salvo nos casos de erro grosseiro ou má-fé do simples excesso de prazo. Logo, o que se tem de reconhecer é que a lei abriu aqui uma exceção à regra segundo a qual o escoamento in albis do prazo para o recurso cabivel faz transitar em julgado a decisão; ou antes, que a res iudicataseforma sob condição resolutiva da subsequente interposição de recurso inadequado, mas conversível no adequado por inexistência de erro grosseiro ou má-fé (cfr. "Juízo de admissibilidade no sistema dos recursos civis", Borsói, Rio de Janeiro, 1968, pp. 50-51).

Nesse sentido é também o entendimento de TERESA ARRUDA AlVIM WAMBIER (cfr. "Os agravos no CPC brasileiro", $4^{\mathrm{a}}$ ed., RT, São Paulo, 2006, p. 161).

${ }^{659}$ Cfr. OLIVEIRA, Guilherme Peres de. "Novo conceito de sentença: análise da jurisprudência acerca do recurso cabivel nas situações duvidosas e aplicação do princípio da fungibilidade", in Revista de Processo, n. 164, RT, São Paulo, out./2008, p. 304.

${ }^{660}$ Cfr. WAMBIER, Teresa Arruda Alvim. "O agravo e o conceito de sentença", in Revista de Processo, n. 144, RT, São Paulo, fev/2007, p. 245.

${ }^{661}$ Cfr. WAMBIER, Teresa Arruda Alvim. "O óbvio que não se vê: a nova forma do princípio da fungibilidade”, in Revista de Processo n. 167, RT, São Paulo, p. 135.
} 
recursal. O recurso da parte deve ser recebido e julgado como tal e não como se outro recurso fosse ${ }^{662}$.

Dessa forma, a má-fé e a conversibilidade formal não devem mais ser consideradas como requisitos para aplicação da fungibilidade recursal. Diante de uma situação de incerteza, formada por grave divergência doutrinária e/ou jurisprudencial, o meio processual empregado pela parte deve ser encarado como apto a alcançar o fim a que se destina, sendo recebido e processado enquanto tal, sem que se proceda a qualquer conversão ${ }^{663}$. Havendo dúvida séria e fundada, não há se falar em exame de eventual má-fé, que era exigido somente no Código de $1939^{664}$.

Nesse sentido, é relevante para a incidência do princípio da fungibilidade tão-somente a existência de dúvida objetiva, de uma zona cinzenta, formada pela existência de divergência de opiniões doutrinárias e jurisprudenciais no País ${ }^{665}$, quanto ao veículo correto para se formular determinada pretensão perante o Judiciário.

Basta, portanto, a seriedade do problema interpretativo acerca da adequação do recurso, sendo irrelevante que o recorrente o tenha solucionado bem ou mal ${ }^{666}$.

Diante das dificuldades práticas que a prolação de sentenças parciais enseja, mostra-se necessária a aplicação ampla do princípio da

\footnotetext{
${ }^{662}$ Cfr. WAMBIER, Teresa Arruda Alvim. "O óbvio que não se vê: a nova forma do princípio da fungibilidade", in Revista de Processo n. 167, RT, São Paulo, p. 136.

${ }^{663}$ Cfr. OLIVEIRA, Guilherme Peres de. "Novo conceito de sentença: análise da jurisprudência acerca do recurso cabivel nas situações duvidosas e aplicação do princípio da fungibilidade", in Revista de Processo, n. 164, RT, São Paulo, out./2008, p. 305.

${ }^{664}$ Cfr. WAMBIER, Teresa Arruda Alvim. "Os agravos no CPC brasileiro", $4^{\mathrm{a}}$ ed., RT, São Paulo, 2006, pp. 166-167.

${ }^{665}$ Nesse sentido, afirma TERESA ARRUDA AlviM WAMBIER ser irrelevante "para fins de incidência do princípio da fungibilidade, que haja unanimidade a respeito do tema no Tribunal" (cfr. "O óbvio que não se vê: a nova forma do princípio da fungibilidade", in Revista de Processo n. 167, RT, São Paulo, p. 135).

${ }^{666}$ Cfr. BARBOSA MOREIRA, José Carlos. "Juízo de admissibilidade no sistema dos recursos civis", Borsói, Rio de Janeiro, 1968, p. 49; v. tb. WAMBIER, Teresa Arruda Alvim. "Os agravos no CPC brasileiro", $4^{\mathrm{a}}$ ed., RT, São Paulo, 2006, p. 157.
} 
fungibilidade recursal $^{667}$, até que nova legislação seja introduzida no sistema processual $^{668}$ ou se firme na jurisprudência um posicionamento ${ }^{669}$.

O juiz, exercendo sua função de presidente do processo, deverá admitir, nos casos limítrofes, a interposição tanto de agravo como de apelação, até que seja consolidada pela doutrina, jurisprudência ou lei uma solução que devolva as necessárias segurança e previsibilidade ao sistema ${ }^{670}$. Destarte, o magistrado deve ter a sensibilidade de receber o recurso interposto pela parte, ainda que entenda não ter sido o adequado à espécie ${ }^{671}$.

Em conclusão, entre agravo de instrumento, apelação por instrumento e formação de autos suplementares, o que não pode se admitir é prejudicar o jurisdicionado, que nada tem a ver com a imprecisão do legislador e com os diversos entendimentos adotados pelos comentadores da lei ${ }^{672}$.

\subsection{JURISPRUDÊNCIA}

A jurisprudência do Superior Tribunal de Justiça ${ }^{673}$ tende a não admitir a figura da sentença parcial, e, consequentemente, nem a incidência da fungibilidade recursal. Contudo, à exceção do entendimento sedimentado no EResp n.

667 Cfr. BUENO, Cássio Scarpinella. "A nova etapa da reforma do Código de Processo Civil: comentários sistemáticos ás Leis n. 11.187, de 19-10-2005, 11.232, de 22-12-2005”, v. 1, Saraiva, São Paulo, 2006, pp. 22-23; Cfr. SICA, Heitor Vitor Mendonça. "Algumas implicações do novo conceito de sentença, de acordo com a Lei n. 11.232/2005”, in CARMONA, Carlos Alberto (coord.). Reflexões sobre a reforma do Código de Processo Civil, Atlas, São Paulo, 2007, p.207.

${ }^{668}$ Cfr. CAMBI, Accácio. "Novo conceito de sentença e sua repercussão no ordenamento processual", in Revista de Processo n. 182, RT, São Paulo, abr./2010, p. 52.

${ }^{669}$ Cfr. NEGRÃO, Theotônio. "Comentários ao Código de Processo Civil e legislação processual em vigor", 40ª ed., Saraiva, São Paulo, 2008, p. 678, nota 3 ao art. 513 do CPC; v. tb. SCARPARO, Eduardo Kochenborger. "Sentenças parciais? Considerações a partir da reforma do art. 162, § $1^{o}$, do Código de Processo Civil", disponível em http://www.scarparo.adv.br/artigos/sent.pdf, acessado em 6.6.11, pp. 2324; SOUZA JUNIOR, Sidney Pereira de. "Sentenças parciais no processo civil - consequências no âmbito recursal", Método, São Paulo, 2009, p. 138.

${ }^{670}$ Cfr. VAREJÃO, José Ricardo do Nascimento. “As classificações, a lei 11.232/2005 e o 'novo' conceito de sentença", in WAMBIER, Teresa Arruda Alvim (coord.). Aspectos Polêmicos da Nova Execução, 3: de títulos judiciais, Lei 11.232/2005, RT, São Paulo, 2006, p. 394.

${ }^{671}$ Cfr. NEVES, Daniel Amorim Assumpção. "O novo conceito de sentença”, in Reforma do CPC: leis 11.187/2005, 11.232/2005, 11.276/2006, 11.276/2006 e 11.280/2006, RT, São Paulo, 2006, p. 85.

${ }^{672}$ Cfr. WAMBIER, Teresa Arruda Alvim. "O óbvio que não se vê: a nova forma do princípio da fungibilidade”, in Revista de Processo n. 167, RT, São Paulo, p. 135.

673 Julgados disponíveis em www.stj.jus.br. 
404.777-SP - e que será analisado no capítulo seguinte - não há qualquer menção à possibilidade de cisão do julgamento de mérito, nem às implicações que daí adviriam.

Sequer a discussão envolvendo as alterações trazidas pela Lei n. 11.232/2005 é tangenciada pela Corte Superior, que se limita a afirmar: (i) ser cabível a interposição de agravo de instrumento contra decisão que não encerra o processo; e (ii) ser impossível a aplicação do princípio da fungibilidade, em razão da inexistência de dúvida objetiva ${ }^{674}$, conforme jurisprudência já sedimentada naquela Corte $^{675}$. Exemplos: AgRg nos EDcl no Ag 1.303.939-SP, $3^{\text {a }}$ T., Rel. Min. SIDNEI BENETI, DJe de 9.8.11; REsp 1.190.974-ES, $2^{\mathrm{a}}$ T., Rel. MIN. HERMAN BENJAMIN, DJe de $1^{\circ} .7 .10 ;$ REsp 1.132.519-ES, $2^{\text {a }}$ T., Rela. Min. ELIANA CALMON, DJe de 21.5.10; REsp 1.184.047-ES, $1^{\mathrm{a}}$ T., Rel. Min. LUIZ FUX, DJe de 3.5.10; AgRg no AgIn n. 908.724-RJ, 6 ${ }^{\mathrm{a}}$ T., Rel. Min. PAUlO GALlOTTI, j. 18.3.08; REsp n. 1.026.021-SP, Rela. Min. NANCY ANDRIGHI, j. 30.4.08; REsp n. 164.729-SP, Rel. Min. SÁLVIO DE FIGUEIREDO TEIXEIRA, j. 1.6.98.

Apesar de o cenário no STJ ser bastante estático, verificase que no âmbito dos Tribunais Estaduais a questão vem sendo debatida de forma bastante produtiva. Para os objetivos deste trabalho, ficar-se-á com o exame da jurisprudência do Tribunal de Justiça do Estado de São Paulo ${ }^{676}$.

É possível observar o convívio de diversos entendimentos díspares, situação que reforça a conclusão de existência de dúvida objetiva acerca do novo conceito de sentença e da definição do recurso adequado à impugnação do ato judicial.

\footnotetext{
${ }^{674}$ De acordo com SIDNEY PEREIRA DE SOUZA JÚNIOR, considerar "erro grosseiro" a interposição de recurso de apelação, afastando-se, assim, a incidência do princípio da fungibilidade, significa "fechar os olhos" para a controvérsia existente na doutrina quanto à definição do novo conceito de sentença (cfr. "Sentenças parciais no processo civil - consequências no âmbito recursal", Método, São Paulo, 2009, p. 143).

${ }^{675}$ Sobre esse aparente descaso com a reforma, afirma GUILHERME PERES DE OliveIRA que "De pronto, chama a atenção (negativamente) a existência de diversas decisões que, a despeito de terem sido proferidas após a entrada em vigor da Lei 11.232/2005, sequer adentram a discussão a que se propõe o presente trabalho, chegando até mesmo a se basear em acórdãos antigos, em que obviamente a discussão não se punha, ao menos não com tamanha intensidade como se verifica atualmente" (Cfr. "Novo conceito de sentença: análise da jurisprudência acerca do recurso cabível nas situações duvidosas e aplicação do princípio da fungibilidade", in Revista de Processo, n. 164, RT, São Paulo, out./2008, p. 299).

${ }^{676}$ Julgados disponíveis em www.tjsp.jus.br.
} 
Prevalece na jurisprudência, assim, que o novo conceito de sentença trazido pela Lei n. 11.232/2005 trouxe incerteza na definição dos provimentos judiciais, de modo a tornar nebulosa a identificação do recurso cabível a sua impugnação. Confira-se:

"A Lei $n^{\circ} 11.232 / 05$ alterou o tradicional conceito de sentença constante do CPC.

\section{(...)}

Pois bem, dentro da sistemática legislativa anterior, se não punha termo ao processo, a decisão não se apresentava como sentença. Em sendo assim, a decisão que não punha termo ao processo não era apelável, mas agravável.

\section{(...)}

Se o conceito de sentença se alterou, é inevitável que se reconheça que o ato não mais se apresenta exclusivamente como aquele que extingue o processo, mas sim - nos precisos termos da lei - que implica alguma das situações previstas nos artigos 267 e 269 do CPC.

\section{(...)}

A decisão em comento inequivocamente implicou uma das situações previstas no art. 269 do CPC. E se assim se deu, não é falta de razão entender que ela tem natureza de sentença. $O$ que antes não se dava, uma vez que só era sentença a decisão que efetivamente extinguia o processo de forma integral - e não com relação a uma ou outra parte.

A diversidade de entendimento a respeito do tema pode levar a situações paradoxais. Imagine-se, no caso dos autos, que posteriormente também seja reconhecida a prescrição no que concerne às autoras remanescentes, depois da instrução, na, diga-se assim, parte final do processo. É o caso de se indagar: na hipótese, a segunda decisão, com as mesmas características da primeira, também será interlocutória? Não se apresentará como sentença? Pelo exemplo, haveria duas decisões idênticas, de mesmo conteúdo, mas uma seria denominada sentença e a outra decisão interlocutória. A circunstância, salvo melhor juízo, é de um ilogicismo a toda prova e acaba por se apresentar, inclusive, como ofensiva ao princípio da isonomia. Sim, pois as agravantes e as autoras que remanesceram nos 
autos receberiam tratamento diferenciado, apesar de a situação de todas ser exatamente a mesma. Enquanto o primeiro ato seria atacável por meio do agravo, o questionamento do segundo se faria pela via da apelação - com prazo mais dilatado, ou seja, com evidente vantagem para quem tivesse à disposição este recurso e não aquele.

Em síntese, em virtude da nova sistemática legal, também é sentença a decisão que pela presença de quaisquer das hipóteses do art. 267 ou do art. 269 do CPC, extingue o processo apenas com relação a uma ou outra parte. E justamente por se apresentar como sentença, o recurso cabível contra tal decisão é mesmo a apelação. O referido entendimento, "data venia" dos que se posicionam de forma diversa, leva a um resultado mais lógico e proporciona tratamento equânime aos envolvidos no processo".

(Cfr. Agravo de Instrumento $\mathrm{n}^{\circ}$ 0441970-66.2010.8.26.0000, Vinhedo, TJSP, $12^{\mathrm{a}}$ Câm. Dir. Priv., Rel. Des. Castro Figliola, j. 2.2.11, v.u.).

“A última reforma do Código de Processo Civil alterou a redação do $\S 1^{\circ}$ do art. 162 (...).

Dada essa alteração, dúvidas surgiram quanto ao recurso cabível nos casos em que era proferida uma decisão que, não obstante não encerrar o processo, tinha conteúdo do art. 267 elou 269, tais como excluir um dos litisconsortes da lide e declarar a prescrição acerca de um dos pedidos da ação"

(Cfr. Agravo de Instrumento n. 994.09.245341-7, Campinas, TJSP, $11^{\text {a }}$ Câm. Dir. Públ., Rel. Des. Oscild de Lima Júnior, j. 18.1.10, v.u.).

“(...) observa-se que o legislador abandonou a utilização exclusiva do critério da eficácia do ato no processo para sua classificação, adotando critério misto. Nessa linha, se o ato do juiz implicar alguma das situações do art. 267 e extinguir o processo (critérios do conteúdo e da eficácia), ou analisar o mérito da demanda nos termos do art. 269 (critério 
do conteúdo), terá natureza de sentença, contra a qual cabe recurso de apelação (art. 513, do CPC).

Diante disso, verifica-se que o conceito de sentença tornou-se controvertido, pois decisões que antes eram tidas como interlocutórias podem, em tese, ser classificadas como sentenças. Tal situação de perplexidade tem se revelado na doutrina, havendo quem sustente somente ser sentença o ato do juiz que, possuindo algum dos conteúdos previstos nos artigos 267 e 269, do CPC, encerra a 'etapa cognitiva' do processo sincrético (cfr. Cássio Scarpinella Bueno, Curso Sistematizado de Direito Processual Civil, v. 5, Saraiva, 2008, p. 115). De outro lado há quem entenda não ter ocorrido qualquer alteração substancial na classificação dos pronunciamentos judiciais (cfr. Barbosa Moreira, A Nova Definição de Sentença, in Temas de Direito Processual, 9a Série, Saraiva, p. 177)".

(Cfr. Agravo de Instrumento n. 920.374-5/2-00, Presidente Prudente, TJSP, $2^{a}$ Câm. Dir. Públ., Rel. Des. Corrêa Vianna, j. 22.9.09, v.u.).

"Em $1^{o}$ grau de jurisdição, dois são os atos judiciais com conteúdo decisório: decisão interlocutória e sentença. Até a vigência da lei 11.232, de 2005, distinguiam-se não por seu conteúdo, mas pelos efeitos produzidos no processo (CPC, art. 162). Este era o critério legal, ainda que passível de críticas.

Se do pronunciamento judicial resultasse a extinção do processo, seria sentença, independentemente da natureza das questões resolvidas. Caso contrário, tratava-se de decisão interlocutória.

O critério agora é outro. Sentença é todo decisório cujo conteúdo esteja previsto nos incisos dos artigos 267, desde que dele resulte a extinção do processo, e 269, independentemente dos efeitos gerados na relação processual (art. 162, $\S 1^{\circ}$ ).

Ainda que a matéria seja controvertida, pois não há consenso na doutrina e na jurisprudência sobre o novo conceito de sentença, a situação dos autos não se subsume a nenhuma das hipóteses legais. 
Um dos litisconsortes deixou de integrar o pólo passivo da relação processual, em decorrência da decisão interlocutória atacada, cujo fundamento é o art. 46, parágrafo único, do Código de Processo Civil. Não se trata de resolução com conteúdo de mérito (art. 269) e essa hipótese legal não está prevista no art. 267.

Em síntese, além de não extinguir o processo, o que continua sendo requisito para caracterizar como sentença o ato decisório com conteúdo processual, o afastamento de litisconsorte para não dificultar o exercício do direito de defesa não constitui nenhuma das situações descritas no art. 267".

(Cfr. Apelação n. 1.196.217-9, São Paulo, TJSP, 22ª Câm. Dir. Priv., Rel. Des. Roberto Bedaque, j. 8.7.08, v.u. ${ }^{677}$ ).

“A nova redação do artigo 162, parágrafo $1 .{ }^{\circ}$, do $C P C$ alterou o critério de distinção entre sentença e decisão interlocutória. Antes do advento da Lei 11.232/2005 era o efeito processual que as diferenciava, pois a sentença punha fim ao processo (com ou sem julgamento do mérito da causa) e a decisão interlocutória nunca encerrava o processo, apenas resolvia questões incidentes. A partir da referida lei é o conteúdo do decisório que as distingue: sentença passou a ser o ato que implica alguma das situações previstas num dos incisos dos artigos 267 e 269 do CPC.

A nova definição, afastando-se do critério topológico, que trazia vantagens práticas no momento de determinar o recurso cabível contra o ato a impugnar, gerou um grave problema no sistema recursal, porquanto o ato judicial que resolve alguma questão de mérito, como no

\footnotetext{
${ }^{677}$ Em relação a esse julgado, é importante destacar que, embora tenha sido reconhecida a controvérsia doutrinária existente em relação ao novo conceito de sentença, a conclusão da $22^{\mathrm{a}}$ Câmara de Direito Privado foi no sentido de inaplicabilidade do princípio da fungibilidade ao caso concreto. Isto porque a decisão recorrida - sem extinguir o processo - teve por conteúdo a exclusão de parcela dos litisconsortes com fundamento no art. 46, parágrafo único, do CPC (limitação do "litisconsórcio facultativo quanto ao número de litigantes, quando este comprometer a rápida solução do litígio ou dificultar a defesa").

Dessa forma, a referida decisão não teve por conteúdo nenhuma das situações previstas nos artigos 267 e 269 do CPC. Assim, seja sob a vigência do conceito original do CPC, seja à luz das alterações trazidas pela Lei n. 11.232/2005, a referida decisão não pode ser considerada sentença: é decisão interlocutória, recorrível por agravo de instrumento.

Diante disso, concluiu-se configurar erro inescusável a interposição de apelação, dada a inexistência de dúvida objetiva.
} 
caso, a exclusão de um litisconsorte, sem solucionar o restante do litígio, nada obstante se subsuma a previsão do artigo 267, VIII, do CPC, sua qualificação como sentença (a desafiar apelação) encontra óbice na mens legis e no propósito da reforma voltada para efetividade e celeridade do processo, pois com a interposição de apelação, o feito ficaria paralisado, pela necessidade de remeter os autos ao Tribunal para apreciação $e$ julgamento do recurso".

(Cfr. Agravo de Instrumento n.1069921- 0/2, São Paulo, TJSP, 36ª Câm. Dir. Priv., Rel. Des. Pedro Baccarat, j. 26.10.06, v.u.).

Diante disso, entende-se deva ser aplicado o princípio da fungibilidade, em razão da notória dúvida objetiva existente:

"Ainda que se entenda que na hipótese o recurso a ser manejado é mesmo o agravo de instrumento, não é possível que não se reconheça, ao menos, que se apresenta como razoável a dúvida sobre o tema- se depois da alteração do art. 162, $\S 1^{o}$ do C.P.C, o recurso cabível é o agravo ou a apelação.

Pois bem, pela existência de dúvida razoável, a interposição do apelo não se caracteriza como erro grosseiro. Assim, na pior das hipóteses, ainda que interposto dentro do prazo da apelação, o recurso das agravantes merecia ser conhecido como agravo como decorrência da aplicação do princípio da fungibilidade”.

(cfr. Agravo de Instrumento n ${ }^{\circ}$ 0441970-66.2010.8.26.0000, Vinhedo, TJSP, $12^{\mathrm{a}}$ Câm. Dir. Priv., Rel. Des. Castro Figliola, j. 2.2.11, v.u.).

“Contudo, em observância ao princípio da fungibilidade, possível o recebimento da apelação como se agravo de instrumento fosse.

Com efeito, para que seja aplicado o princípio da fungibilidade necessário se faz que (i) haja dúvida objetiva acerca de qual recurso é cabível, afastando-se, portanto, casos de erro grosseiro e (ii) o 
recurso que se pretenda ser recebido, tenha sido interposto no prazo legal do tido como correto. O requisito temporal, conforme cópias dos autos, foi atendido.

A dúvida objetiva, por sua vez, conforme acima explicitado, existiu, (...)".

(Cfr. Agravo de Instrumento n. 994.09.245341-7, Campinas, TJSP, $11^{\text {a }}$ Câm. Dir. Públ., Rel. Des. Oscild de Lima Júnior, j. 18.1.10, v.u.).

"Destarte, dada a notória controvérsia sobre a natureza do ato decisório, resta configurada a dúvida objetiva acerca do recurso adequado, de modo que não podem os agravantes ser apenados pela incerteza decorrente da imprecisão técnica e da desestruturação do sistema processual introduzidas pelo legislador. Note-se, por fim, que o recurso de apelação foi protocolado dentro do prazo para interposição do agravo de instrumento (fls. 26/27), o que revela a inexistência de má-fé por parte dos recorrentes, circunstância que vai ao encontro da conclusão de aplicação do princípio da fungibilidade recursal ao caso concreto".

(Cfr. Agravo de Instrumento n. 920.374-5/2-00, Presidente Prudente, TJSP, $2^{\text {a }}$ Câm. Dir. Públ., Rel. Des. Corrêa Vianna, j. 22.9.09, v.u.).

"Diante da dúvida atual na doutrina acerca do recurso cabível contra a decisão que homologa a desistência da ação em relação a um dos litisconsortes passivos, vale dizer, se o novo conceito de sentença alterou ou não a sistemática recursal preestabelecida, impõe-se a aplicação do princípio da fungibilidade para receber a apelação interposta como agravo face a ausência de erro grosseiro e porque respeitado o decêndio legal".

(Cfr. Agravo de Instrumento n.1069921- 0/2, São Paulo, TJSP, 36 Câm. Dir. Priv., Rel. Des. Pedro Baccarat, j. 26.10.06, v.u.).

Além disso, já se adotou o entendimento defendido nesse capítulo acerca do recurso cabível contra a sentença parcial de mérito: interposição de apelação e formação de autos suplementares. Veja-se: 
"Por conta disso, deve ter regular processamento a apelação interposta pelos agravantes. Uma observação final é necessária. Para que se processe a apelação, sem que fique prejudicado o regular andamento do processo, evidentemente deverão ser formados autos suplementares".

(Cfr. Agravo de Instrumento n. 0441970-66.2010.8.26.0000, Vinhedo, TJSP, $12^{a}$ Câm. Dir. Priv., Rel. Des. Castro Figliola, j. 2.2.11, v.u.).

"Em resumo, o agravo de instrumento deve ser provido, a fim de que seja recebido o recurso de apelação, determinando-se seu regular processamento, com conseqüente remessa dos autos a esta E. Corte. Observe-se que o d. magistrado deverá, ainda, determinar a extração de cópias das peças processuais necessárias a fim de se formarem autos suplementares, possibilitando-se, assim, o prosseguimento do processo em primeiro grau de jurisdição enquanto o apelo é processado e julgado pelo Tribunal, tendo em vista que nem todas as questões discutidas no processo são objeto do referido recurso".

(Cfr. Agravo de Instrumento n. 920.374-5/2-00, Presidente Prudente, TJSP, $2^{\text {a }}$ Câm. Dir. Públ., Rel. Des. Corrêa Vianna, j. 22.9.09, v.u.).

Não obstante haja posicionamento diverso ${ }^{678}$, é possível concluir que no Tribunal de Justiça do Estado de São Paulo prevalece o entendimento de que as alterações, trazidas pelo legislador no conceito de sentença, causaram sérias controvérsias na classificação dos provimentos judiciais e na identificação dos recursos cabíveis. Sendo assim, configurou-se situação de dúvida objetiva apta a ensejar a incidência do princípio da fungibilidade recursal, de forma a não se apenar as partes em razão de situação de insegurança jurídica a que não colaboraram nem deram causa.

\footnotetext{
${ }^{678}$ Cfr. Agravo de Instrumento n. 1.158.070- 0/7, Santo André, TJSP, $26^{a}$ Câm. Dir. Priv., Rel. Des.
} Vianna Cotrim, j. 11.8.08, v.u. 


\section{IMPLICACÕES NA FORMACÃO DA COISA JULGADA MATERIAL}

O legislador, ao criar o instituto da coisa julgada, não teve como objetivo precípuo a preservação da verdade ou da justiça. Buscou atender a valor de ordem bem mais prática, consubstanciado na segurança jurídica e na paz social, por meio da impossibilidade de se rediscutir questões já definitivamente resolvidas pelo Judiciário $^{679}$.

A preocupação com a segurança jurídica não se restringe à legislação processual infraconstitucional, tendo sido tratada pela Constituição da República, no preâmbulo e no caput do art. $5^{0^{680}}$. Sendo assim, trata-se de instituto de destacada importância no sistema processual, cuja desconsideração somente pode ser admitida em hipóteses excepcionais.

Com a possibilidade de generalização das sentenças parciais de mérito no procedimento, ganha relevante destaque o fenômeno da formação progressiva da coisa julgada, a qual é admitida pela doutrina na hipótese de divisão da sentença em capítulos autônomos. Se houver interposição de recurso contra apenas alguns destes capítulos, aqueles não impugnados, e que não guardem relação de prejudicialidade com os recorridos, transitarão imediatamente em julgado ${ }^{681}$.

Ao apelar somente do capítulo que julgou improcedente parte do pedido, o autor define os limites objetivos do recurso interposto. O Tribunal poderá julgá-lo livremente, mas este resultado, caso as questões decididas sejam

\footnotetext{
${ }^{679}$ Cfr. THEODORO JUNIOR, Humberto. "Coisa julgada: pluralidade e unicidade (súmula n. 401 do STJ)”, disponível em http://www.rkladvocacia.com/arquivos/artigos/art_srt_arquivo20111212104742.pdf, acessado em 23.1.12, p. 3.

${ }^{680}$ Cfr. THEODORO JUNIOR, Humberto. "Coisa julgada: pluralidade e unicidade (súmula n. 401 do STJ)”, disponível em http://www.rkladvocacia.com/arquivos/artigos/art_srt_arquivo20111212104742.pdf, acessado em 23.1.12, p. 4.

${ }^{681}$ Cfr. SOUZA JUNIOR, Sidney Pereira de. "Sentenças parciais no processo civil - consequências no âmbito recursal”, Método, São Paulo, 2009, p. 180.
} 
independentes, não terá influência sobre o capítulo não recorrido, visto este ter transitado em julgado ${ }^{682}$.

Havendo julgamento fracionado do mérito, ocorreria situação análoga à acima identificada. Em ambos os casos há uma cisão no exame da demanda: no primeiro, por iniciativa da parte; no segundo, por decisão judicial. Dessa forma, o mérito passa a ser analisado por mais de uma decisão no mesmo processo, possibilitando, assim, a aquisição da qualidade de coisa julgada material, de forma independente, por cada uma das sentenças parciais.

Se a parcela de mérito analisada for autônoma e logicamente independente em relação ao restante do objeto do processo ${ }^{683}$, com o trânsito em julgado a decisão parcial de mérito não poderá ser alterada, sob pena de ofensa à coisa julgada material.

Nesse sentido, necessário analisar como ocorre o indigitado fenômeno, passando pelo exame de algumas questões: (i) termo inicial do prazo decadencial de ajuizamento da ação rescisória; (ii) a competência para processar e julgar a rescisória em relação ao órgão prolator de cada uma das decisões parciais de mérito; (iii) a possibilidade de ajuizamento de uma rescisória para cada sentença parcial de mérito ${ }^{684}$; (iv) incongruência entre coisas julgadas parciais; (v) execução.

\subsection{TERMO INICIAL DO PRAZO DECADENCIAL DE AJUIZAMENTO DA ACÃO RESCISÓRIA}

\section{Segundo ATHOS GuSMÃo CARNEIRO, “a ação rescisória} revela-se como meio autônomo de impugnação a atos jurisdicionais de mérito, com remota origem na 'querela nullitatis' e na 'restitutio in integrum', distinguindo-se dos

\footnotetext{
${ }^{682}$ Cfr. BONÍCIO, Marcelo José Magalhães. "Capítulos de sentença e efeitos dos recursos", RCS Editora, São Paulo, 2006, p. 107.

${ }^{683}$ Cfr. DIAS, Jean Carlos. "A configuração da coisa julgada parcial e suas repercussões processuais no âmbito do cumprimento das sentenças", in Revista de Processo n. 135, RT, São Paulo, maio de 2006, p. 272.

${ }^{684}$ Cfr. SOUZA JUNIOR, Sidney Pereira de. "Sentenças parciais no processo civil - consequências no âmbito recursal”, Método, São Paulo, 2009, p. 193.
} 
recursos porque estes impugnam o ato jurisdicional no mesmo processo em que foi proferido o provimento atacado; já a rescisória dá início a uma outra relação processual, pressupondo o encerramento definitivo da relação processual originária, com o trânsito em julgado da decisão de mérito"685.

Na linha da lição acima, a doutrina entende pela ampliação do cabimento da ação rescisória, de forma a abarcar todas as hipóteses em que a decisão tivesse conteúdo de sentença de mérito, inclusive nos casos de decisão interlocutória ${ }^{686}$.

Todavia, a Lei n. 11.232/05 tornou desnecessária tal construção, visto que estes pronunciamentos de mérito interlocutórios passaram a dever ser classificados como sentenças, pois o critério adotado pelo legislador para sua definição, conforme já asseverado, foi o do conteúdo e não mais o da eficácia extintiva.

Nesse sentido, o fenômeno da coisa julgada parcial verifica-se, a rigor, sempre que uma decisão contendo mais de um capítulo de mérito é objeto de recurso parcial, de modo que o capítulo não impugnado transitaria imediatamente em julgado ${ }^{687}$.

Vale dizer, a interposição de recurso contra parcela dos capítulos da sentença de mérito não posterga a imutabilidade material dos capítulos não recorridos. O prazo para a rescisão destes se inicia independentemente do término do julgamento daqueles, bem como de seu resultado.

Tal raciocínio pode ser perfeitamente transportado para as situações de julgamento fracionado do mérito, diante da semelhança existente entre os fenômenos.

\footnotetext{
685 Cfr. "Ação rescisória, biênio decadencial e recurso parcial", disponível em http://www.abdpc.org.br/abdpc/artigos/Athos\%20Gusm\%C3\%A3o\%20Carneiro\%20formatado.pdf, acessado em 19.1.12, p. 4.

${ }^{686}$ Cfr. WAMBIER, Teresa Arruda Alvim. "Os agravos no CPC brasileiro", $4^{\mathrm{a}}$ ed., RT, São Paulo, 2006, p. 114; v. tb.; Cfr. ARAÚJO, José Henrique Mouta. "Coisa julgada progressiva \& resolução parcial do mérito", Juruá, Curitiba, 2008, p. 362.

${ }^{687}$ Cfr. ARAÚJO, José Henrique Mouta. "Coisa julgada progressiva \& resolução parcial do mérito", Juruá, Curitiba, 2008, p. 352.
} 
Dessa forma, o termo inicial do prazo para propositura da ação rescisória se dará com o trânsito em julgado da sentença parcial de mérito, podendo a referida demanda desconstitutiva ser ajuizada antes mesmo de encerrado o processo no qual a decisão rescindenda foi proferida ${ }^{688}$.

No entanto, a conclusão acima alcançada, apesar de correta, não é pacífica e nem mesmo dominante na jurisprudência, em especial no Superior Tribunal de Justiça, que veio a sumular entendimento diametralmente oposto.

Sobre o início da fluência do prazo decadencial, havia, inicialmente, dois posicionamentos ${ }^{689}$ :

(i) o termo a quo se verificaria com o trânsito em julgado de cada capítulo da decisão ${ }^{690}$. Por esta corrente, a decisão de inadmissibilidade de eventual recurso interposto se limitaria adeclarar uma situação de fato que já ocorreu. $O$ trânsito em julgado poderia ocorrer, então, em duas ocasiões: (a) em se tratando de sentença irrecorrível, no momento de sua publicação; (b) caso se trate de sentença recorrível, no instante em que ocorreu a circunstância que tornou a decisão não mais passível de recurso (v.g., preclusão temporal).

(ii) o termo inicial ocorreria com o trânsito em julgado da última decisão proferida no processo, ainda que referente à inadmissibilidade de recurso - salvo hipótese de intempestividade ${ }^{691}$. Para este segmento, o trânsito em julgado da decisão não ocorre na pendência de recurso inadmissível, verificando-se somente quando se tornar irrecorrível a decisão de não conhecimento do referido recurso.

\footnotetext{
688 Cfr. ARAÚJO, José Henrique Mouta. "Tutela antecipada do pedido incontroverso: estamos preparados para a nova sistemática processual?", in Revista de Processo, n. 116, p. 226.

${ }^{689}$ Cfr. BARBOSA MOREIRA, José Carlos. "Sentença objetivamente complexa, trânsito em julgado e rescindibilidade", in Revista de Processo, n. 141, RT, São Paulo, nov./2006, p. 11.

${ }^{690}$ Cfr. REsp nn.381.531; 201.668, 212.286; 278.614; 293.926.

${ }^{691}$ Cfr. REspnn.404.777; 639.233; 267.602; 543.368; 281.393.
} 
Prevaleceu o segundo entendimento, adotado pela Corte Especial do Superior Tribunal de Justiça, no julgamento do EREspn. 404.777-DF, e, posteriormente, culminando com a edição da Súmula n. $401^{692}$, assim redigida:

“O prazo decadencial da ação rescisória só se inicia quando não for cabível qualquer recurso do último pronunciamento judicial".

Para se entender o contexto de aplicação da súmula e suas implicações, é importante transcrever a ementa do referido julgado, que embasou a sua confecção:

a) "A coisa julgada material é a qualidade conferida por lei à sentença/acórdão que resolve todas as questões suscitadas pondo fim ao processo, extinguindo, pois, a lide".

b) "Sendo a ação una e indivisível, não há que se falar em fracionamento da sentençalacórdão, o que afasta a possibilidade do seu trânsito em julgado parcial".

c) "Consoante o disposto no art. 495 do CPC, o direito de propor a ação rescisória se extingue após o decurso de dois anos contados dotrânsito em julgado da última decisão proferida na causa”.

Entretanto, esses fundamentos adotados pela Corte para chegar à conclusão alcançada são criticados de forma incisiva pela doutrina ${ }^{693}$, visto que a fluência do prazo da rescisória não tem qualquer relação com a possibilidade de cisão do exame do mérito, na hipótese de demandas cumuladas ou de pedido decomponível ${ }^{694}$.

\footnotetext{
${ }^{692} \mathrm{Cfr}$. FLACH, Rafael. "A súmula 401 do Superior Tribunal de Justiça e a coisa julgada progressiva”, in Revista de Processo, n. 185, RT, São Paulo, julho de 2010, p. 176.

${ }^{693}$ Cfr. THEODORO JUNIOR, Humberto. "Coisa julgada: pluralidade e unicidade (súmula n. 401 do STJ)”, disponível em http://www.rkladvocacia.com/arquivos/artigos/art_srt_arquivo20111212104742.pdf, acessado em 23.1.12, pp. 13-14.

${ }^{694}$ BARBOSA MOREIRA é incisivo em sua crítica: "A leitura atenta dos votos sugere algumas observações. É que, de envolta com argumentos pertinentes de um e de outro lado, se inseriu na discussão certo número de temas a rigor estranhos ao julgamento, ou - diga-se com os mais respeitosos pedidos de vênia - tratados sem a necessária precisão técnica, ou explorados de maneira inconsequente" (cfr. "Sentença objetivamente complexa, trânsito em julgado e rescindibilidade", in Revista de Processo, n. 141, RT, São Paulo, nov./2006, p. 9).
} 
O que motivou a decisão analisada foi a perplexidade dos julgadores ante a pretensamente indesejada possibilidade de propositura de diversas rescisórias contra as sucessivas decisões de mérito produzidas ao longo do mesmo processo, o que implicaria, em relação a cada uma delas, a fluência autônoma dos prazos decadenciais de ajuizamento.

Porém, a solução indicada pelo Superior Tribunal de Justiça, além de não ter o condão de alcançar o objetivo proposto, traz óbices indevidos ao julgamento fracionado do mérito. Para se chegar à conclusão de fluência única do prazo decadencial da ação rescisória, assentou-se que somente a decisão final do processo teria aptidão a transitar materialmente em julgado, sendo impossível a cisão da decisão de mérito, em razão de uma suposta unicidade do direito de ação.

Com a devida vênia, não se pode concordar com a referida construção, por diversas razões, a seguir analisadas.

\section{a) JULGAMENTO DE ACÃO RESCISÓRIA DE DECISÕES PARCIAIS DE MÉRITO PROFERIDAS POR ÓRGÃOS JURISDICIONAIS DIVERSOS}

Alega-se que a admissibilidade da formação fracionada da coisa julgada material causaria balbúrdia processual, já que ensejaria o ajuizamento de múltiplas ações rescisórias contra decisões proferidas no mesmo processo ${ }^{695}$.

Contudo, a solução adotada no indigitado julgado não tem o condão de evitar esse suposto problema, visto que, a depender do momento e do grau de jurisdição em que é definitivamente julgada parcela da decisão impugnada, haverá variação na identificação do Tribunal competente para o julgamento de tais ações ${ }^{696}$.

\footnotetext{
${ }^{695}$ Cfr. FLACH, Rafael. "A súmula 401 do Superior Tribunal de Justiça e a coisa julgada progressiva", in Revista de Processo, n. 185, RT, São Paulo, julho de 2010, p. 201.

${ }^{696}$ Cfr. FLACH, Rafael. "A súmula 401 do Superior Tribunal de Justiça e a coisa julgada progressiva", in Revista de Processo, n. 185, RT, São Paulo, julho de 2010, p. 203.
} 
Nesse sentido, a competência para julgamento da rescisória deve ser examinada de forma individualizada, a partir da identificação do órgão prolator da decisão parcial de mérito a ser rescindida ${ }^{697}$.

Caso haja capítulos de mérito examinados por decisões de diferentes tribunais (v.g., Tribunal de Justiça e Superior Tribunal de Justiça), é impossível o ajuizamento de ação rescisória única, pois cada Corte tem competência para rescindir somente seus julgados. Inadmissível que o STJ rescinda julgado do Tribunal local, e vice-versa. Diante disso, resta clara a confusão instrumental consagrada no entendimento sumulado ${ }^{698}$.

Dessa forma, se o objeto da rescisória nunca tiver sido decidido pelo Superior Tribunal de Justiça, não será sua a competência para seu processamento e julgamento, ainda que o último recurso do processo, no qual a decisão rescindenda foi proferida, tenha sido examinado pelo STJ $^{699}$.

Nessa linha, observa-se que o entendimento criticado não tem o condão de afastar a possibilidade de ajuizamento de mais de uma rescisória, ainda que se considere que o prazo decadencial tenha início no mesmo momento (extinção do feito) para todas as decisões proferidas.

Ora, se em sentença parcial de mérito, a última palavra acerca da matéria foi dada pelo Tribunal de Justiça, no julgamento de apelação, enquanto a sentença final foi proferida pelo Superior Tribunal de Justiça, no julgamento de Recurso Especial, a possibilidade de pluralidade de ações rescisórias resta mantida. Isto porque a ação rescisória cabível contra a decisão do Tribunal de Justiça não poderá ser julgada pelo STJ, visto que não há previsão constitucional a respeito; nem a decisão

\footnotetext{
${ }^{697}$ Cfr. SOUZA JUNIOR, Sidney Pereira de. "Sentenças parciais no processo civil - consequências no âmbito recursal", Método, São Paulo, 2009, p. 197.

${ }^{698}$ Cfr. THEODORO JUNIOR, Humberto. "Coisa julgada: pluralidade e unicidade (súmula n. 401 do STJ)”, disponível em http://www.rkladvocacia.com/arquivos/artigos/art_srt_arquivo20111212104742.pdf, acessado em 23.1.12, pp. 14-16.

${ }^{699}$ Cfr. THEODORO JUNIOR, Humberto. "Coisa julgada: pluralidade e unicidade (súmula n. 401 do STJ)", disponível em http://www.rkladvocacia.com/arquivos/artigos/art_srt_arquivo20111212104742.pdf, acessado em 23.1.12, p. 17.
} 
da Corte Superior poderá ser rescindida pelo Tribunal local, sob pena de violação ao art. 105, I, da Constituição Federal ${ }^{700}$.

Destarte, a extensão do objeto da ação rescisória não deve ser medida pelo pedido formulado pela parte, mas sim pela decisão a ser desconstituída. Assim, se a inicial trazia três pedidos, sendo que o primeiro deles transitou em julgado em primeiro grau, o segundo, no Tribunal local, e o terceiro, no Superior Tribunal de Justiça, deverão ser ajuizadas três ações rescisórias distintas, com pressupostos inclusive prazo - independentes ${ }^{701}$.

Portanto, deverá haver, necessariamente, "tantas ações rescisórias quantas as decisões transitadas em julgado em diferentes juízos"702.

O entendimento adotado pelo Superior Tribunal de Justiça, em suposta homenagem ao princípio da unicidade da sentença, mostra-se flagrantemente inútil ao fim que se propõe. Nada impede que, ao longo do mesmo processo, sejam proferidas mais de uma manifestação sobre o mérito, até mesmo por órgãos diferentes - seja em caso de julgamento fracionado do mérito ou de capítulos de mérito parcialmente recorridos.

Consequentemente, será necessário ajuizar uma rescisória para cada decisão de mérito, não havendo qualquer vantagem em uniformizar arbitrariamente o início do prazo decadencial para todas, visto que os julgamentos são totalmente independentes. Assim, dúvidas não há de que o trânsito em julgado das decisões parciais de mérito deve ocorrer de forma autônoma, bem como a fixação do termo a quo dos respectivos biênios ${ }^{703}$.

Nessa senda, se se tratar de questões autônomas solucionadas em decisões diferentes, não há qualquer sentido em unificar o início do

\footnotetext{
700 Cfr. BARBOSA MOREIRA, José Carlos. "Sentença objetivamente complexa, trânsito em julgado e rescindibilidade", in Revista de Processo, n. 141, RT, São Paulo, nov./2006, p. 17.

${ }^{701}$ Cfr. PONTES DE MIRANDA, Francisco Cavalcanti. "Tratado da ação rescisória", 5 a ed., Forense, Rio de Janeiro, 1976, p. 353.

${ }^{702}$ Cfr. PONTES DE MIRANDA, Francisco Cavalcanti. "Tratado da ação rescisória”, 5a ed., Forense, Rio de Janeiro, 1976, p. 353.

${ }^{703}$ Cfr. BARBOSA MOREIRA, José Carlos. "Sentença objetivamente complexa, trânsito em julgado e rescindibilidade”, in Revista de Processo, n. 141, RT, São Paulo, nov./2006, p. 19.
} 
prazo da ação rescisória ${ }^{704}$, inexistindo inconveniência no julgamento de mais de uma ação rescisória referente a capítulos de uma mesma decisão, resolvidos por Tribunais diferentes. Com efeito, não há contradição ou interferência entre tais julgados, justamente pelo fato de a demanda ter se fracionado em capítulos distintos e autônomos, de modo que rescisão de um não obsta a persistência do outro ${ }^{705}$.

A conclusão acima pode ser aplicada integralmente à hipótese de prolação de sentenças parciais de mérito. Por se tratar de demandas autônomas, que poderiam ser veiculadas em processos distintos, nada impede sejam apreciadas em sentenças diferentes, no mesmo processo.

Nesse sentido, afirma BARBOSA MOREIRA que "se se quiser pleitear a rescisão de ambas as decisões, a circunstância de contar-se o prazo decadencial a partir do mesmo momento não implicará que se possam cumular os dois pedidos numa mesma ação rescisória: cada pleito terá de ser proposto em separado, e perante tribunais diferentes. Isso se faz gritantemente nítido na hipótese de serem distintos os legitimados à propositura, como ocorrerá se no julgamento da apelação houver sido vitorioso um dos litigantes, e no do recurso especial o outro; mas a afirmação vale para qualquer hipótese" ${ }^{\text {706 }}$. Estaria mantido, portanto, o "inconveniente" da multiplicidade de rescisórias, ainda que se afirme início de prazo comum a todas - circunstância admitida até mesmo entre os defensores da impossibilidade do trânsito em julgado material arcial $^{707}$.

Ainda quanto à possibilidade de multiplicidade de rescisórias, invoca-se argumento de ordem prática, igualmente tendente a obstar o trânsito em julgado parcial.

\footnotetext{
${ }^{704}$ Cfr. THEODORO JUNIOR, Humberto. "Coisa julgada: pluralidade e unicidade (súmula n. 401 do STJ)", disponível em http://www.rkladvocacia.com/arquivos/artigos/art_srt_arquivo20111212104742.pdf, acessado em 23.1.12, pp. 18-19.

${ }^{705}$ Cfr. THEODORO JUNIOR, Humberto. “Coisa julgada: pluralidade e unicidade (súmula n. 401 do STJ)", disponível em http://www.rkladvocacia.com/arquivos/artigos/art_srt_arquivo20111212104742.pdf, acessado em 23.1.12, p. 21.

${ }^{706}$ Cfr. BARBOSA MOREIRA, José Carlos. "Sentença objetivamente complexa, trânsito em julgado e rescindibilidade", in Revista de Processo, n. 141, RT, São Paulo, nov./2006, pp. 17-18.

707 Cfr. TEIXEIRA, Guilherme Puchalski. "Sentenças objetivamente complexas: impossibilidade do trânsito em julgado parcial”, in Revista de Processo n. 162, RT, São Paulo, agosto de 2008, p.247.
} 
Aduz-se que a resolução de ações rescisórias incidentais, aliada à necessária existência de nexo de prejudicialidade entre os capítulos da sentença (v.g., capítulos processuais em relação a capítulos de mérito), poderia causar reflexos no julgamento do restante do litígio ${ }^{708}$.

Sendo assim, se fosse julgado procedente pedido em ação rescisória contra sentença parcial de mérito e ainda estivesse pendente o processo na qual foi proferida, o resultado daquela poderia ter o condão de influir neste. Esse cenário desaconselharia a admissão da fragmentação do trânsito em julgado material.

Exemplo de fácil assimilação é o caso de reconhecimento da ausência de um requisito de análise do julgamento de mérito, comum a todas as pretensões deduzidas (v.g. ilegitimidade passiva ad causam). Diante disso, o Tribunal, ao julgar a rescisória, determinaria: (i) a desconstituição da decisão rescindenda; e (ii) o rejulgamento da demanda, com a consequente extinção do processo sem resolução de mérito. O que fazer com eventuais pedidos que ainda estão sendo analisados em primeiro grau de jurisdição e que sofrem os reflexos de tal decisão?

Aparentemente, não há como negar que os pedidos subsequentes restariam prejudicados pela decisão do Tribunal, à semelhança do que ocorre em relação ao pedido sucessivo em face do julgamento de improcedência do pedido primário, em grau recursal. Destarte, deverá o juiz adotar o entendimento utilizado no julgamento da ação rescisória, obstando imediatamente o prosseguimento manifestamente inútil de processo inapto a produzir resultados práticos.

Não se observa, entretanto, qualquer inconveniência no expediente acima sugerido ${ }^{709}$. Ao revés, a determinação de extinção imediata do processo representa fator de celeridade processual, visto que antecipa decisão que somente seria tomada em sede recursal ou em rescisória. Assim, o simples fato de o

${ }^{708}$ Cfr. TEIXEIRA, Guilherme Puchalski. "Sentenças objetivamente complexas: impossibilidade do trânsito em julgado parcial", in Revista de Processo n. 162, RT, São Paulo, agosto de 2008, p.245.

${ }^{709}$ Indo de encontro ao afirmado, asseveraGuILHERME PUCHALSKI TEIXEIRA que "as razões de conveniência acima suscitadas parecem ser suficientes para se criar um consenso em torno do qual mesmo para aqueles que admitem o trânsito em julgado parcial da sentença - deve-se aguardar o trânsito em julgado da última decisão proferida no processo para que então passe a correr o prazo para o ajuizamento da rescisória" (cfr. "Sentenças objetivamente complexas: impossibilidade do trânsito em julgado parcial", in Revista de Processo n. 162, RT, São Paulo, agosto de 2008, p. 247). 
resultado da rescisória ter a potencialidade de influenciar no julgamento do restante do objeto processual não é motivo apto, por si só, a afastar a ocorrência do fenômeno da formação progressiva da coisa julgada.

\section{b) UNICIDADE DA ACÃO E COISA JULGADA MATERIAL}

O Superior Tribunal de Justiça foi altamente impreciso ao afirmar que a ação é una. Isto porque, ainda que haja pedido simples, este poderá dar ensejo a capítulos de mérito diversos, na hipótese de objeto processual decomponível.

Assim, se o autor pede 100, a sentença lhe concede 50 e o Tribunal, ao julgar seu apelo, aumenta seu proveito em mais 25 , haverá a formação de mais provimento jurisdicional com mais de um capítulo de mérito em primeiro grau, sendo que um deles ainda será objeto de decisão em grau recursal. A ação una deu origem a duas decisões de mérito, proferidas, no caso, por órgãos jurisdicionais diversos. É um fato.

Além disso, é corriqueira no foro a cumulação de demandas, na qual cada uma delas formará um capítulo de mérito na sentença ${ }^{710}$. E como defendido, em se tratando de demandas autônomas e independentes, que permitam a identificação de unidades elementares, nada obsta que o julgamento de mérito seja fracionado pelo próprio magistrado de primeiro grau.

Dessa forma, o STJ desprezou a teoria dos capítulos de sentença $^{711}$, bem como a possibilidade de cisão do julgamento de mérito. Agasalhou posicionamento segundo o qual o termo a quo do biênio decadencial da rescisória somente se iniciaria no dia em que a última decisão proferida no processo transitou em julgado, ainda que esta verse exclusivamente sobre questão processual. Invocando-se o

\footnotetext{
${ }^{710} \mathrm{Cfr}$. BARBOSA MOREIRA, José Carlos. "Sentença objetivamente complexa, trânsito em julgado e rescindibilidade", in Revista de Processo, n. 141, RT, São Paulo, nov./2006, pp. 14-15.

${ }^{711}$ Cfr. FLACH, Rafael. "A súmula 401 do Superior Tribunal de Justiça e a coisa julgada progressiva", in Revista de Processo, n. 185, RT, São Paulo, julho de 2010, p. 179.
} 
princípio da unicidade da sentença, inviabilizou-se a formação progressiva da coisa julgada material $^{712}$.

Ocorre que, como examinado, o princípio da unicidade da sentença perdeu grande parte da força que lhe era atribuída. Não serve, portanto, de argumento para obstar a cisão do julgamento de mérito, nem a formação progressiva da coisa julgada, principalmente em razão de a adoção de tal entendimento não trazer nenhum benefício prático.

Não há relação de dependência, portanto, entre a pretensa unicidade da ação e a viabilidade de prolação de mais de uma decisão de mérito, cada qual abordando parcela do objeto processual.

Nessa linha, não se pode concordar com o entendimento que não aceita a formação progressiva da coisa julgada, sob o fundamento de que, embora vários pedidos sejam formulados, a ação é única, de modo que una será a sentença. Para tal posição, a resposta dada pelo Judiciário às partes tem de ser completa, de modo que o trânsito em julgado material somente ocorreria em relação à decisão que analisou integralmente a lide ${ }^{713}$.

c) DESNECESSIDADE DE DECISÃO DE TODAS AS QUESTÕES DE MÉRITO OU DE EXTINCÃ̃O DO PROCESSO PARA FORMAC̃̃O DA COISA JULGADA

\section{MATERIAL}

Ainda de acordo com o entendimento do STJ, apenas a sentença final do processo seria capaz de produzir coisa julgada material, enquanto as demais, embora de mérito, teriam a aptidão para, quando muito, transitarem

\footnotetext{
${ }^{712}$ Cfr. MARTINS, Sandro Gilbert. "Reflexos do novo conceito de sentença $\left(C P C\right.$, art. $162, \S 1^{o}$, com a redação dada pela Lei 11.232/2005)”, in Revista de Processo, n. 163, RT, São Paulo, set./2008, p. 311.

${ }_{713}$ Cfr. TEIXEIRA, Guilherme Puchalski. "Sentenças objetivamente complexas: impossibilidade do trânsito em julgado parcial”, in Revista de Processo n. 162, RT, São Paulo, agosto de 2008, p. 238.
} 
formalmente em julgado. Tal conclusão impediria o ajuizamento de ação rescisória enquanto ainda pendente o processo.

Afirma-se, assim, que somente seria imutável a sentença não mais sujeita a recurso, de modo que não possui tal atributo a sentença contra a qual penda recurso parcial $^{714}$.

De acordo com essa corrente, se houver recurso contra apenas um dos pedidos decididos pela sentença, e o Tribunal, ao julgá-lo, reconhecer a existência de questões de ordem pública (artigos $267, \S 3^{\circ}$, e 301 , do CPC), o decreto de extinção do processo sem resolução do mérito deverá alcançar também a parte não impugnada ${ }^{715}$.

Diante disso, considera-se que a extinção do processo é requisito para o ajuizamento da ação rescisória ${ }^{716}$, visto que antes desse fenômeno operar-se-ia tão-somente a coisa julgada formal ou a preclusão, não havendo se falar em coisa julgada material $^{717}$.

Nada mais equivocado, com a devida vênia. Tal posicionamento apresenta raciocínio, no mínimo, contraditório. Num primeiro momento faz-se uma interpretação estritamente literal de dispositivo legal, fechando-se os olhos para o sistema processual vigente, para, logo em seguida, criar requisito específico não previsto expressamente em lei para a utilização de meio autônomo de impugnação, tão somente em decorrência daquela interpretação textual inicial. Busca-se, em verdade, adequar a realidade à teoria, numa inversão clara e insustentável de papéis.

Interessante notar que, como decorrência lógica daquele argumento, também seria impossível o ajuizamento de rescisória após o encerramento do processo, visto que sua extinção não possui o condão de transformar coisa julgada

${ }^{714}$ Cfr. TEIXEIRA, Guilherme Puchalski. "Sentenças objetivamente complexas: impossibilidade do trânsito em julgado parcial", in Revista de Processo n. 162, RT, São Paulo, agosto de 2008, p. 239.

${ }^{715}$ Cfr. TEIXEIRA, Guilherme Puchalski. "Sentenças objetivamente complexas: impossibilidade do trânsito em julgado parcial", in Revista de Processo n. 162, RT, São Paulo, agosto de 2008, pp. 243-244.

${ }^{716}$ Cfr. TEIXEIRA, Guilherme Puchalski. "Sentenças objetivamente complexas: impossibilidade do trânsito em julgado parcial”, in Revista de Processo n. 162, RT, São Paulo, agosto de 2008, p. 240.

${ }^{717}$ Cfr. TEIXEIRA, Guilherme Puchalski. "Sentenças objetivamente complexas: impossibilidade do trânsito em julgado parcial", in Revista de Processo n. 162, RT, São Paulo, agosto de 2008, pp. 240-242. 
formal em coisa julgada material, encontrando, assim óbice no caput do art. 485, do Código de Processo Civil ${ }^{718}$.

Além disso, há manifesto equívoco ao se considerar que a coisa julgada material somente é adquirida pela decisão que resolver todas as questões. O “decidir todas as questões" pode ser analisado sob dois prismas: o da fundamentação, no qual o juiz efetivamente deve decidir, incidentalmente, todas as questões de mérito; e o do dispositivo, no qual o juiz decide acerca da pretensão formulada, do mérito.

Ora, o fato de uma decisão ter fundamentação deficiente ou ter decidido menos que o efetivamente pedido (vício citra petita) não impede a ocorrência de trânsito em julgado material, em relação àquilo que foi apreciado no provimento judicial.

$\mathrm{Na}$ verdade, tais defeitos dão ensejo ao próprio ajuizamento da ação rescisória, o que torna indubitável a ocorrência do trânsito em julgado material dessas sentenças ${ }^{719}$. Assim, manifestamente equivocado atrelar a formação da coisa julgada material à decisão de todas as questões.

O fenômeno da formação progressiva da coisa julgada material não está condicionado à extinção do processo, a qual não tem o condão de transformar preclusão em trânsito em julgado. Destarte, se a decisão analisa o mérito do processo, ainda que parcialmente, estará apta a transitar materialmente em julgado, sendo, para tanto, irrelevante o momento processual em que é prolatada ${ }^{720}$.

O termo a quo do prazo da rescisória deve ser contado a partir do trânsito em julgado de cada sentença parcial de mérito, e não da estabilização adquirida pela última decisão prolatada no processo $^{721}$. A parcela do objeto processual analisada pela sentença parcial de mérito não poderá sequer ser reapreciada pela decisão

\footnotetext{
${ }^{718} \mathrm{Cfr}$. BARBOSA MOREIRA, José Carlos. "Sentença objetivamente complexa, trânsito em julgado e rescindibilidade", in Revista de Processo, n. 141, RT, São Paulo, nov./2006, p. 12.

${ }^{719}$ Cfr. BARBOSA MOREIRA, José Carlos. "Sentença objetivamente complexa, trânsito em julgado e rescindibilidade", in Revista de Processo, n. 141, RT, São Paulo, nov./2006, p. 16.

${ }^{720}$ Cfr. FLACH, Rafael. "A súmula 401 do Superior Tribunal de Justiça e a coisa julgada progressiva", in Revista de Processo, n. 185, RT, São Paulo, julho de 2010, p. 191.

${ }_{721}$ Cfr. SOUZA JUNIOR, Sidney Pereira de. "Sentenças parciais no processo civil - consequências no âmbito recursal”, Método, São Paulo, 2009, pp. 195-197.
} 
final, seja por força do art. 463, do Código de Processo Civil, seja em razão da formação de coisa julgada material ${ }^{722}$.

\section{d) ADMISSIBILIDADE DA FORMACÃO PROGRESSIVA DA COISA JULGADA}

Do exposto, foi possível verificar que o entendimento adotado pelo Superior Tribunal de Justiça é equivocado, pois, além de não atingir o escopo visado, obsta a formação da coisa julgada progressiva, visto que não considera possível a ocorrência do fenômeno do trânsito em julgado em momentos processuais diversos ${ }^{723}$.

Assim, faz-se necessário destacar que, não obstante seja minoritária, a posição rejeitada pelo STJ encontra respaldo em sólidos fundamentos.

Nesse sentido, é de se notar que o Tribunal Superior do Trabalho, no item II de sua Súmula n. 100, adota posicionamento em sentido correta e diametralmente oposto ao assentado pelo Superior Tribunal. De acordo com o entendimento da Corte Trabalhista, na hipótese de recurso parcial, o trânsito em julgado da decisão ocorrerá em momentos e em tribunais diferentes. Dessa forma, o prazo para ajuizamento de rescisória começará a correr a partir de cada trânsito em julgado de cada decisão que julgar o recurso parcial. ${ }^{724}$

\footnotetext{
${ }^{722}$ Cfr. ARAÚJO, José Henrique Mouta. "Coisa julgada progressiva \& resolução parcial do mérito", Juruá, Curitiba, 2008, p. 381.

${ }^{723}$ Cfr. FLACH, Rafael. "A súmula 401 do Superior Tribunal de Justiça e a coisa julgada progressiva", in Revista de Processo, n. 185, RT, São Paulo, julho de 2010, p. 176.

${ }^{724}$ In verbis:

Súmula 100, TST:

"[...]

II - Havendo recurso parcial no processo principal, o trânsito em julgado dá-se em momentos e em tribunais diferentes, contando-se o prazo decadencial para a ação rescisória do trânsito em julgado de cada decisão, salvo se o recurso tratar de preliminar ou prejudicial que possa tornar insubsistente a decisão recorrida, hipótese em que flui a decadência a partir do trânsito em julgado da decisão que julgar o recurso parcial. (ex-Súmula $n^{\circ} 100$ - alterada pela Res. 109/2001, DJ 20.04.01).

$[\ldots] "$.
} 
Diante da similaridade entre as situações, esta conclusão pode ser aplicada analogicamente às sentenças parciais de mérito. Assim como no recurso parcial, haverá trânsito em julgado em momentos diferentes, não em razão de impugnação pela parte, mas por cisão do julgamento de mérito pelo magistrado. Destarte, o prazo para ajuizamento da ação rescisória deve ter início com o trânsito em julgado de cada decisão parcial de mérito.

Se há recurso parcial, os capítulos não impugnados, se de mérito, transitam materialmente em julgado, podendo ser executados de forma definitiva e imediata ${ }^{725}$.

Se a sentença possui partes autônomas e destacáveis, nada impede que, em grau recursal, haja mais de uma cognição parcial. Diante disso, a coisa julgada poderá se formar em momentos diferentes para cada um dos capítulos da res in iudicium deducta ${ }^{726}$.

Ainda indo de encontro ao posicionamento do E. Superior Tribunal de Justiça, há acórdão proferido pelo Supremo Tribunal Federal, no qual a questão da formação progressiva da coisa julgada foi examinada pelo Pleno.

Trata-se da Ação Rescisória, n. 903, julgada em 17 de junho de 1982, na qual o Supremo assentou que os embargos de divergência, interpostos contra o acórdão que dá provimento ao recurso extraordinário, somente obsta seu trânsito em julgado se abranger a integralidade da decisão recorrida. Nessa linha, se abranger apenas alguns capítulos da decisão, os demais transitarão em julgado.

Do julgado extrai-se seguinte excerto do voto do Ministro Moreira Alves:

"Ora, a interposição de embargos de divergência contra acórdão que conhece do recurso extraordinário e lhe dá provimento para julgar

\footnotetext{
${ }^{725}$ Cfr. GARCIA, Gustavo Filipe Barbosa. "Capítulos autônomos da decisão e momentos de seu trânsito em julgado", in Revista de Processo n. 111, RT, São Paulo, 2003, p. 296.

${ }^{726}$ Cfr. CARNEIRO, Athos Gusmão. "Ação rescisória, biênio decadencial e recurso parcial", disponível em http://www.abdpc.org.br/abdpc/artigos/Athos\%20Gusm\%C3\%A3o\%20Carneiro\%20formatado.pdf, acessado em 19.1.12, p. 9.
} 
procedente a ação, só impede o trânsito em julgado deste se abarca todas as questões da demanda, uma vez que, se abranger apenas algumas delas, com relação às demais ocorre a coisa julgada. Isso se explica pelo fato de que os embargos de divergência não devolvem ao Plenário desta Corte a apreciação de toda a matéria de que tratou o aresto embargado, mas apenas daquelas sobre as quais versa a divergência. Não fora assim e, dizendo os embargos respeito apenas a, por exemplo, questão relativa a honorários de advogado, a decisão de mérito não transitaria em julgado, embora os embargos não a abrangessem e não houvesse, portanto, possibilidade de modificação dela. É a aplicação do princípio de que o recurso parcial não impede o trânsito em julgado da parte da sentença que não foi por ela abarcada"727.

Destarte, a Suprema Corte reconheceu a possibilidade do trânsito em julgado progressivo, limitado a apenas alguns dos capítulos de mérito da decisão. Sendo assim, nada impede que este entendimento seja transportado para a categoria das sentenças parciais de mérito, visto que há extrema similitude entre os fenômenos: em ambos os casos há o julgamento de uma parcela da demanda, cuja decisão se torna imutável antes do restante do objeto litigioso do processo. Assim, onde há a mesma razão, deve ser aplicado o mesmo direito.

Se for interposto recurso parcial contra a sentença de mérito, os capítulos irrecorridos transitam em julgado imediatamente, caso, além de autônomos, sejam também independentes.

No entanto, se existir nexo de prejudicialidade entre o capítulo recorrido e o não recorrido, este não transitará em julgado. Exemplo: foi interposto recurso apenas contra o capítulo que decretou a rescisão do contrato, restando irrecorrida a parte da decisão que determinou a devolução da coisa. Não é possível admitir que tenha havido o trânsito em julgado da decisão neste último ponto, já que se o Tribunal reconhecer a subsistência do contrato, a restituição será indevida ${ }^{728}$.

\footnotetext{
727 RTJ 103/483, apud CARNEIRO, Athos Gusmão. "Ação rescisória, biênio decadencial e recurso parcial", disponível http://www.abdpc.org.br/abdpc/artigos/Athos\%20Gusm\%C3\%A3o\%20Carneiro\%20formatado.pdf, acessado em 19.1.12, p. 11.

${ }^{728}$ Cfr. THEODORO JUNIOR, Humberto. “Coisa julgada: pluralidade e unicidade (súmula n. 401 do STJ)", disponível em http://www.rkladvocacia.com/arquivos/artigos/art_srt_arquivo20111212104742.pdf, acessado em 23.1.12, pp. 11-12.
} 
Além disso, a formação progressiva da coisa julgada é expressamente admitida pelo Código de Processo Civil. Dispõe o parágrafo único do art. 498 que, na hipótese de acórdão contendo capítulos de mérito unânime e por maioria de votos, caso não sejam interpostos embargos infringentes, o prazo para interposição de recursos especial e extraordinário, em relação à parte unânime, terá início com o trânsito em julgado do capítulo não unânime ${ }^{729}$. Sendo assim, o próprio Código prevê a possibilidade de a coisa julgada material ser formada em momentos processuais diferentes.

Perfeitamente admissível, portanto, a formação parcial da coisa julgada, bem como o ajuizamento de mais de uma rescisória, em razão do trânsito em julgado de capítulos da decisão em momentos diversos ${ }^{730}$.

Arrematando, sustenta HUMBERTO THEODORO JÚNIOR que "a atual posição do STJ de contar o prazo para a propositura da ação rescisória uma única vez a partir do último recurso julgado, mesmo que este se refira a questão meramente processual, além de indispor com a doutrina tradicional, desestabiliza a coisa julgada, ampliando injustificadamente o prazo de rescisão. Se, de um lado, procura prestigiar o princípio da justiça, por outro, agride, sem razão de ser, o da segurança jurídica, que na espécie se ampara na prefixação de um prazo curto e fatal para a ação rescisória" ${ }^{\text {731. }}$.

Em conclusão, não há dúvidas acerca da formação progressiva da coisa julgada na hipótese de cisão do julgamento do mérito. O trânsito em julgado material independe da extinção do processo e da solução integral da lide trazida a juízo, sendo certo que este último fenômeno não tem o condão de transformar em coisa julgada as decisões anteriormente preclusas. Assim, se a decisão parcial de

\footnotetext{
${ }^{729}$ Cfr. THEODORO JUNIOR, Humberto. "Coisa julgada: pluralidade e unicidade (súmula n. 401 do STJ)”, disponível em http://www.rkladvocacia.com/arquivos/artigos/art_srt_arquivo20111212104742.pdf, acessado em 23.1.12, p. 12.

${ }^{730}$ Cfr. THEODORO JUNIOR, Humberto. "Coisa julgada: pluralidade e unicidade (súmula n. 401 do STJ)", disponível em http://www.rkladvocacia.com/arquivos/artigos/art_srt_arquivo20111212104742.pdf, acessado em 23.1.12, p. 12.

731 Cfr. "Coisa julgada: pluralidade e unicidade (súmula n. 401 do STJ)", disponível em http://www.rkladvocacia.com/arquivos/artigos/art_srt_arquivo20111212104742.pdf, acessado em 23.1.12, p. 24.
} 
mérito é fundada em cognição exauriente, tendo aptidão a se tornar definitiva, é capaz de adquirir a qualidade de coisa julgada material ${ }^{732}$.

\subsection{EXCECÃO À FORMAC̃̃̃O DA COISA JULGADA PROGRESSIVA}

Entende-se que o trânsito em julgado parcial não poderá ocorrer na hipótese de cumulação sucessiva de pedidos, caso seja interposto recurso somente contra o julgamento de procedência do pedido primário. Diante do nexo de prejudicialidade existente entre as pretensões cumuladas, amplia-se o âmbito da devolução recursal, de modo que o Tribunal poderá alterar o pedido sucessivo não impugnado $^{733}$.

Ainda que inexistente norma expressa, essa devolução a maior do recurso interposto deve ser admitida, pois seria incoerente reunir pretensões num mesmo processo sob o pretexto de economia processual e de harmonia entre julgados, para, logo depois, renunciar a tais objetivos e permitir seja a causa prejudicada julgada de forma incompatível com a causa prejudicial $^{734}$.

Pense-se, na situação em que o juiz julga procedente demanda com pedidos de declaração de paternidade e de condenação a pagamento de alimentos, e o réu interpõe recurso apenas quanto à pretensão declaratória. $\mathrm{O}$ Tribunal dá provimento à apelação, para julgar improcedente o pedido de declaração. Diante de tal resultado, a condenação à prestação de alimentos é logicamente insustentável, de modo que, em razão do nexo de prejudicialidade existente, o pedido sucessivo também é reformado pelo provimento do referido recurso.

\footnotetext{
${ }^{732}$ Cfr. FLACH, Rafael. "A súmula 401 do Superior Tribunal de Justiça e a coisa julgada progressiva", in Revista de Processo, n. 185, RT, São Paulo, julho de 2010, p. 208.

733 Cfr. TEIXEIRA, Guilherme Puchalski. "Sentenças objetivamente complexas: impossibilidade do trânsito em julgado parcial", in Revista de Processo n. 162, RT, São Paulo, agosto de 2008, pp. 238-239. ${ }^{734}$ Cfr. DINAMARCO, Cândido Rangel. "Capítulos de sentença", $4^{\mathrm{a}}$ ed., Malheiros, São Paulo, 2009, p. 111.
} 
Entretanto, a ampliação do efeito devolutivo é excepcional, de modo que a mera conexão entre demandas não a autoriza. Indispensável se estabeleça relação de prejudicialidade, sob pena de ofensa ao art. 515, caput, do $\mathrm{CPC}^{735}$.

É importante observar que este cenário não se apresenta na hipótese de cisão de julgamento do mérito. Se nessa mesma demanda o juiz proferisse sentença parcial de mérito, declarando a paternidade, e determinasse o prosseguimento do processo para análise da responsabilidade alimentar, a falta de interposição de recurso contra a primeira sentença implicaria seu trânsito em julgado material e, consequentemente, sua imutabilidade.

De outro lado, se o réu dela apelasse, e o tribunal desse provimento a seu recurso, o prosseguimento do processo em relação ao pedido sucessivo restaria prejudicado. Diante de tal situação duas soluções se abririam ao magistrado: (i) extinção do processo sem resolução de mérito, diante da superveniente ausência de interesse de agir, já que o pedido primário foi rejeitado; ou (ii) reconhecimento da manifesta improcedência de tal pretensão, visto que dirigida a quem reconhecidamente não tem responsabilidade pelo adimplemento da obrigação.

Assim, o capítulo da sentença que julga o pedido sucessivo ou subsidiário,caso não seja objeto de recurso parcial, não transitará em julgado antes do exame final do pedido primário, diante da relação de prejudicialidade existente. Assim, como ainda não se formou a coisa julgada material, contra ele não caberá o ajuizamento de ação rescisória ${ }^{736}$.

Como dito, tal raciocínio não se aplica na hipótese de cisão do julgamento de mérito, pois esta somente poderá incidir sobre o pedido primário, não sendo admissível que se profira sentença parcial de mérito em relação ao pedido subsequente.

\footnotetext{
${ }^{735}$ Cfr. DINAMARCO, Cândido Rangel. "Capítulos de sentença”, $4^{\mathrm{a}}$ ed., Malheiros, São Paulo, 2009, p. 112.

${ }^{736}$ Cfr. THEODORO JUNIOR, Humberto. "Coisa julgada: pluralidade e unicidade (súmula n. 401 do STJ)", disponível em http://www.rkladvocacia.com/arquivos/artigos/art_srt_arquivo20111212104742.pdf, acessado em 23.1.12, p. 13.
} 


\subsection{INCONGRUÊNCIAS ENTRE COISAS JULGADAS ORIUNDAS DO MESMO PROCESSO}

Por questão de segurança jurídica e em homenagem à razoável duração do processo, não é admissível que a parcela do mérito já julgada e não recorrida seja alterada em razão de provimento de eventual recurso interposto contra decisão proferida ao final do processo ${ }^{737}$.

A formação progressiva da coisa julgada é fenômeno que decorre naturalmente da cisão do julgamento de mérito, não podendo ser desconstituída por outra via que não a da ação rescisória ${ }^{738}$.

No ponto, é relevante notar que a garantia oferecida pela coisa julgada exclui apenas o conflito prático entre julgados, não visando a evitar, de forma absoluta, a incongruência lógica entre decisões transitadas em julgado ${ }^{739}$.

A possibilidade de incongruência lógica entre decisões de mérito não é novidade no sistema $^{740}$, sendo passível de verificação na hipótese de recurso dirigido apenas contra alguns dos capítulos da sentença de mérito, ou mesmo nas hipóteses de execução provisória ${ }^{741}$. Destarte, não configura motivo apto a afastar a possibilidade de a sentença parcial de mérito transitar em julgado de forma autônoma.

É de se observar que se o magistrado de primeiro grau ou o Tribunal, em grau recursal, ao apreciar o pedido restante, extinguir o processo sem julgamento de mérito, a sentença parcial de mérito não poderá ser modificada. Há autonomia entre as pretensões cujo julgamento foi cindido e, consequentemente,

\footnotetext{
${ }^{737}$ Cfr. ARAÚJO, José Henrique Mouta. "Coisa julgada progressiva \& resolução parcial do mérito", Juruá, Curitiba, 2008, p. 353.

${ }^{738}$ Cfr. ARAÚJO, José Henrique Mouta. "Coisa julgada progressiva \& resolução parcial do mérito", Juruá, Curitiba, 2008, p. 354.

${ }_{739}$ Cfr. CHIOVENDA, Giuseppe. "Instituições de direito processual civil", Bookseller, Campinas, 2009, p. 495.

${ }_{740}$ Cfr. ARAÚJO, José Henrique Mouta. "Coisa julgada progressiva \& resolução parcial do mérito", Juruá, Curitiba, 2008, p. 355.

${ }^{741}$ Cfr. ARAÚJO, José Henrique Mouta. "Coisa julgada progressiva \& resolução parcial do mérito", Juruá, Curitiba, 2008, p. 383.
} 
formação de coisa julgada material em relação à decisão parcial de mérito ${ }^{742}$. Tal disparidade entre as decisões, num mesmo processo, é perfeitamente admissível no sistema $^{743}$.

\section{O exemplo de CÂNDIDO RANGEl DinAmarco é}

esclarecedor:

"Situação muito análoga é a de um fundamento suficiente para reformar pelo mérito o julgamento de mais de um capítulo, mas cuja imposição fica restrita ao capítulo que houver sido objeto do recurso, sem atingir os demais. Se o juiz julgou parcialmente procedente um pedido de condenação em dinheiro e somente o autor apelou, entende-se devolvido ao tribunal exclusivamente o capítulo referente ao valor negado pelo juiz de primeiro grau, não o que concedeu ao autor parte do que pedira. Se o réu, sem haver apelado, nas contra-razões ao recurso do autor alegar a prescrição, esta poderá ser conhecida pelo tribunal, porque comporta alegação em qualquer tempo e grau (CC, art. 193); mas o réu não se beneficiará dessa causa extintiva em relação à parcela da obrigação incluída no capítulo não-recorrido, porque, como nos demais casos de recurso parcial, este estará coberto pela coisa julgada"744.

Ora, a segurança jurídica e a duração menor do processo são valores que devem preponderar sobre a possibilidade de incongruência ${ }^{745}$. Ademais, considerar que o recurso interposto posteriormente, por meio de eventual efeito translativo, poderia atingir a sentença parcial de mérito irrecorrida implica afronta aos artigos 128 e 460, do Código de Processo Civil, além de dar aplicação equivocada à extensão do efeito devolutivo dos recursos ${ }^{746}$.

\footnotetext{
${ }^{742}$ Cfr. SOUZA JUNIOR, Sidney Pereira de. "Sentenças parciais no processo civil - consequências no âmbito recursal", Método, São Paulo, 2009, p. 183.

743 Cfr. BONÍCIO, Marcelo José Magalhães. "Capítulos de sentença e efeitos dos recursos", RCS Editora, São Paulo, 2006, p. 172.

${ }^{744}$ Cfr. DINAMARCO, Cândido Rangel. “Capítulos de sentença”, 4 ed., Malheiros, São Paulo, 2009, p. 114-115.

${ }^{745}$ Cfr. ARAÚJO, José Henrique Mouta. "Coisa julgada progressiva \& resolução parcial do mérito", Juruá, Curitiba, 2008, p. 383.

${ }^{746}$ Cfr. FLACH, Rafael. "A súmula 401 do Superior Tribunal de Justiça e a coisa julgada progressiva", in Revista de Processo, n. 185, RT, São Paulo, julho de 2010, p. 194.
} 
Dessa forma, as discrepâncias lógicas eventualmente existentes são relevantes apenas no campo das preocupações teóricas, pois cada uma das decisões parciais de mérito, por serem autônomas, é capaz de produzir seus efeitos práticos, independentemente de qualquer outra circunstância ${ }^{747}$.

\subsection{EXECUCÃO DEFINITIVA DA SENTENCA DE MÉRITO PARCIAL TRANSITADA EM JULGADO}

Poderia, então, a sentença parcial de mérito embasar execução definitiva?

Pois bem: (i) se "é definitiva a execução da sentença transitada em julgado" (art. 475-I, § 1º do CPC); e (ii) se "denomina-se coisa julgada material a eficácia, que torna imutável e indiscutível a sentença, não mais sujeita a recurso ordinário ou extraordinário" (art. 467, do CPC); conclui-se, portanto, que, uma vez não mais sujeitas a recurso, as sentenças parciais de mérito adquirem a qualidade de coisa julgada material, podendo ser executadas de imediato e de forma definitiva ${ }^{748}$.

Destarte, sua execução independe do destino da parcela do objeto do processo que não foi por ela analisada ${ }^{749}$.

Ora, a sentença parcial de mérito difere da sentença definitiva, apenas, por não julgar, de uma só vez, a integralidade do objeto litigioso do processo. Tanto na definitiva quanto na parcial o juiz examina o mérito da causa de forma exauriente, não sendo possível às partes rediscutir a matéria decidida. A definitividade é inerente a todas as sentenças ${ }^{750}$.

\footnotetext{
${ }^{747}$ Cfr. DINAMARCO, Cândido Rangel. "Capítulos de sentença", $4^{\mathrm{a}}$ ed., Malheiros, São Paulo, 2009, p. 114.

${ }^{748}$ Cfr. FLACH, Rafael. "A súmula 401 do Superior Tribunal de Justiça e a coisa julgada progressiva”, in Revista de Processo, n. 185, RT, São Paulo, julho de 2010, p. 197.

${ }^{749}$ Cfr. ARAÚJO, José Henrique Mouta. "Coisa julgada progressiva \& resolução parcial do mérito", Juruá, Curitiba, 2008, pp. 368-369.

${ }^{750}$ Cfr. SILVA, Ovídio Araújo Baptista da. "Da sentença liminar à nulidade da sentença", Forense, Rio de Janeiro, 2002, pp. 20-21.
} 
Dessa forma, a execução da sentença parcial de mérito não será provisória, ainda mais se considerando que o julgamento da parcela da demanda restante não terá qualquer influência sobre o já decidido e materialmente transitado em julgado $^{751}$.

E como operacionalizar na prática tal execução? Aparentemente não há grandes dificuldades, visto que o sistema comporta a possibilidade de uma sentença conter uma parte líquida e outra ilíquida. Em tal situação, a lei é explícita ao autorizar a simultaneidade dos procedimentos (art. 475-I, § $2^{\circ}$, do Código de Processo Civil), sendo que em um deles serão utilizados os autos principais e, no outro, cópias a serem extraídas (o que era chamado de carta de sentença) ${ }^{752}$.

Nessa linha, nada obsta a adoção analógica desta solução, diante da similaridade das hipóteses.

A coisa julgada é uma qualidade da decisão de mérito ${ }^{753}$. Entender que esta se verificaria apenas uma vez no curso do processo implica lhe desvirtuar e subutilizar sua real capacidade de pacificação social ${ }^{754}$. Obstar a admissibilidade da formação progressiva da coisa julgada viola o disposto nos artigos $2^{\circ}$ e 460, do Código de Processo Civil, bem como ao princípio tantum devolutum quantum apelatum $^{755}$.

Não haveria qualquer sentido em admitir a existência de sentenças parciais de mérito sem que pudessem adquirir a qualidade de coisa julgada

\footnotetext{
${ }^{751}$ Cfr. SOUZA JUNIOR, Sidney Pereira de. "Sentenças parciais no processo civil - consequências no âmbito recursal”, Método, São Paulo, 2009, p. 185.

${ }^{752}$ Cfr. DINAMARCO, Cândido Rangel. "Capítulos de sentença”, 4ª ed., Malheiros, São Paulo, 2009, p. 127.

753 A concepção de CHIOVENDA, pela qual "a coisa julgada é a eficácia própria da sentença que acolhe ou rejeita a demanda" não prevaleceu entre nós (cfr. "Instituições de direito processual civil", Bookseller, Campinas, 2009, p. 453). O ordenamento jurídico brasileiro adotou a teoria de LIEBMAN, que, como dito, compreende a coisa julgada como qualidade do ato decisório, "mais intensa e mais profunda, que reveste o ato também em seu conteúdo e torna assim imutáveis, além do ato em sua existência formal, os efeitos, quaisquer que sejam, do próprio ato" (cfr. "Eficácia e autoridade da sentença", $3^{\mathrm{a}}$ ed., Forense, Rio de Janeiro, 1984, p.54).

${ }^{754}$ Cfr. ARAÚJO, José Henrique Mouta. "Coisa julgada progressiva \& resolução parcial do mérito", Juruá, Curitiba, 2008, p. 351.

${ }^{755}$ Cfr. ARAÚJO, José Henrique Mouta. "Coisa julgada progressiva \& resolução parcial do mérito", Juruá, Curitiba, 2008, p. 387.
} 
material $^{756}$. Ora, se a decisão é prolatada com base em cognição exauriente, não há razões para negar-lhe o caráter de definitividade.

Assim, rejeitar a formação da coisa julgada material parcial atenta contra os princípios da efetividade processual e da segurança jurídica. Não se pode aceitar que a parte seja surpreendida com a reforma de uma decisão já transitada em julgado, realizada em razão de um suposto efeito translativo.

Além disso, obstar a imediata execução definitiva fere de morte os princípios da celeridade e da economia processual, visto que não há sentido em estender o processo no tempo, se a tutela jurisdicional já pode ser imediatamente realizada $^{757}$.

${ }^{756}$ Cfr. SOUZA JUNIOR, Sidney Pereira de. "Sentenças parciais no processo civil - consequências no âmbito recursal", Método, São Paulo, 2009, p. 179.

${ }^{757}$ Cfr. FLACH, Rafael. "A súmula 401 do Superior Tribunal de Justiça e a coisa julgada progressiva", in Revista de Processo, n. 185, RT, São Paulo, julho de 2010, p. 204-205. 


\section{CONCLUSÕES}

Do exposto, extraem-se as seguintes conclusões:

i. O Poder Judiciário encontra-se em crise, o que gera o descrédito da população em relação a sua atuação.

ii. Uma das causas de tal cenário é a excessiva morosidade processual, sendo que a Lei n. 11.232/05 visou a conferir maior efetividade à tutela jurisdicional condenatória, criando o processo sincrético.

iii. Em razão dessa reforma processual, foi necessário alterar o conceito de sentença, tendo sido adotado o critério de definição pelo conteúdo e não mais pela eficácia extintiva ou pela topologia do ato.

iv. O novo conceito de sentença representou rompimento do sistema processual com o princípio da unicidade, de modo a possibilitar a decomponibilidade do objeto litigioso do processo, por meio da prolação de sentenças parciais de mérito.

v. No Código de Processo Civil de 1939, eram previstos dois tipos de sentença: definitiva (analisa o mérito da demanda) e terminativa (extinção do processo sem julgamento de mérito). Contra a primeira cabia apelação; contra a segunda, agravo de petição. Assim, a identificação do recurso adequado era feita por meio do critério do conteúdo da decisão, o que gerava insegurança jurídica.

vi. Em 1973, o legislador alterou o conceito de sentença adotando critério topológico para sua identificação. Sentença passou o ato do juiz que extinguia o processo, com ou sem exame de mérito. Essa nova técnica legislativa facilitou sobremaneira a identificação do recurso cabível: se o processo fosse extinto, estar-se-ia diante de sentença, recorrível por apelação; se o processo não fosse extinto, estar-se-ia diante de decisão interlocutória, recorrível por agravo,

vii. Entretanto, a simplificação do sistema recursal não conseguiu, por si só, dotar o processo da efetividade dele esperada. Foi necessária modificação na estrutura do sistema processual, abolindo-se a dicotomia existente entre processo de cognição e processo de execução: a efetivação do direito declarado passou a ser realizada no mesmo processo, dito sincrético. 
viii. Nessa linha, a Lei n. 11.232/05 alterou o conceito de sentença, visto que essa não mais extinguia o processo, que deveria prosseguir na fase executiva. Foi adotada definição fundada no conteúdo do ato, sendo classificado como sentença o provimento judicial que contivesse alguma das hipóteses previstas nos artigos 267 e 269, do Código de Processo Civil.

ix. Diante das alterações havidas, é possível concluir que o conceito de sentença é definido pelo legislador, conforme os escopos visados, os quais decorrem da política processual adotada em determinado momento histórico, devendo, portanto, ser analisado à luz da ordem jurídica vigente.

x. De acordo com a sistemática vigente, podem ser identificadas duas modalidades de sentença: a definitiva, que analisa o mérito, de acordo com as hipóteses previstas no art. 269, do CPC, independentemente de extinguir ou não o processo; a terminativa, que extingue o processo sem julgamento do mérito, por alguma das hipóteses previstas no art. 267, do CPC. Na realidade, adotou-se critério misto para a definição de sentença, já que a eficácia extintiva ainda foi mantida em relação às sentenças terminativas.

xi. A decisão fundada em alguma das hipóteses previstas no art. 267, do CPC, mas que não tem o condão de extinguir o processo é interlocutória.

xii. A Lei n. 11.232/2005 inseriu expressamente no Código de Processo Civil a possibilidade de análise fracionada do objeto do processo por meio de sentenças parciais de mérito, as quais são definidas exclusivamente com base em seu conteúdo. Não é possível haver sentença terminativa parcial, visto que esta ainda tem o condão de necessariamenteextinguir o processo.

xiii. O julgamento parcelado e diferido do mérito é meio de atender ao interesse das partes em ver seus litígios resolvidos com inegável maior rapidez, consubstanciando-se, assim, em importante ferramenta de concretização da garantia constitucional de acesso à "ordem jurídica justa”.

xiv. Os provimentos parciais de mérito não podem ser classificados como decisões interlocutórias, pois não é viável considerar a resolução de uma das demandas propostas em juízo como mera questão incidente (art. 162, § $2^{\circ}$, do Código de Processo Civil), visto que se trata de decisão sobre o próprio objeto do processo.

xv. $\mathrm{O}$ atual conceito legal de sentença enseja o reconhecimento da possibilidade de sua prolação em relação a parcela das pretensões deduzidas, sendo que a 
negativa da existência das sentenças parciais causa insegurança jurídica, por retirar a previsibilidade inerente ao ordenamento jurídico .

xvi. Não há sentido em incentivar o jurisdicionado a cumular demandas, sem a possibilidade de, na hipótese de se mostrar vantajoso, julgá-las em momentos diferentes.

xvii. Verificada a viabilidade do fracionamento do julgamento do objeto do processo, é dever do magistrado proferir sentença parcial, pois a indevida procrastinação de sua apreciação, para o final desenrolar do processo, atenta contra os princípios da efetividade e da celeridade e contra o senso de justiça

xviii. O julgamento fracionado do mérito poderá ser efetivado em favor do réu, sujeito processual igualmente destinatário da garantia constitucional à duração razoável do processo.

xix. A prolação de sentença parcial não ofende ao contraditório, nem à isonomia, os quais devem ser assegurados às partes. O magistrado oferecerá aos sujeitos processuais parciais as mesmas oportunidades para se manifestar, bem como os mesmos instrumentos lhes estarão à disposição para fazerem valer seus direitos.

xx. Eventuais dificuldades envolvendo o sistema recursal não servem de argumento contrário à prolação de sentenças parciais de mérito. A recorribilidade de tais decisões é que tem de ser esclarecida pelos operadores do direito, e não sua prolação evitada.

xxi. É adequado fazer um paralelo entre o julgamento fracionado do mérito e a teoria dos capítulos de sentença.

xxii. Os capítulos de sentença se verificam quando o petitumdá ensejo a decisum formalmente único, mas com diversos itens, decorrentes da existência de pretensões distintas ou de pretensão que possa ser fragmentada, com a característica de que cada uma delas era passível de ser julgada em processos separados.

xxiii. Se a natureza do objeto do processo ensejará sentença integrada por mais de uma unidade elementar, não há óbice que cada uma dessas unidades, na hipótese de vierem a se tornar maduras para julgamento antes das demais, seja cindida em sentenças diferentes. Se for possível o plus de serem julgadas separadamente, em processos diferentes, não há como se negar o minus de julgá-las separadamente no mesmo processo. 
xxiv. Assim, o ponto de encontro entre a cisão do julgamento do mérito e a teoria dos capítulos de sentença é justamente esse: o julgamento fracionado do mérito pode incidir nas situações em que se formariam capítulos de mérito autônomos, ou seja, quando houver objeto processual complexo ou decomponível.

xxv. A cisão do exame do mérito encontra dois grandes óbices teóricos à sua ampla efetivação: princípio da unicidade da sentença e princípio da correlação. Porém, devem ser superados em homenagem à garantia constitucional a um processo com duração razoável.

xxvi. O dogma da unicidade do julgamento de mérito representa, na verdade, um mito, pois o próprio Código de Processo Civil sempre previu, de forma expressa, situações em que, dentro do mesmo processo e em razão da natureza deste, proferir-se-iam mais de uma sentença, que, sendo sucessivas, na verdade, seriam parciais (v.g., ação de prestação de contas, ação de consignação em pagamento, ação demarcatória).

xxvii. O ideal de decisório único não pode ser mantido a todo custo, sacrificando-se a celeridade e comprometendo-se a obtenção de tutela jurisdicional tempestiva, num processo de duração razoável e sem dilações indevidas.

xxviii. A Lei n. 11.232/05, ao retirar a eficácia extintiva da sentença, permitiu fossem proferidos mais de um ato dessa natureza no mesmo processo.

xxix. Não é razoável nem proporcional que se privilegie a unicidade do ato sentencial em detrimento da efetividade processual, em plena afronta à nova redação do art. 162, § $1^{\circ}$, do Código de Processo Civil.

xxx. Da análise sistemática e teleológica dos artigos $162, \S 1^{\circ}$, e 269 , caput, do Código de Processo Civil, é possível concluir que o legislador reformista rompeu de vez com o dogma da unicidade do julgamento de mérito, constatação que encontra fundamento de validade nos incisos XXXV e LXXVIII, do art. $5^{\circ}$, da Constituição Federal.

xxxi. A sentença citra petita é aquela que não possui algum capítulo de mérito indispensável, implicando denegação de justiça e desconsideração à própria garantia constitucional do direito de acesso à Justiça. Entretanto, tal vício não ocorre na sentença parcial, visto que o pedido não analisado será objeto de decisão posterior, não havendo se falar em ausência de capítulo de mérito indispensável, nem em violação à garantia constitucional de acesso ao Judiciário. 
xxxii. Os fenômenos da sentença parcial e da sentença infra petita são inconfundíveis. Nessa última o órgão jurisdicional comete uma ilegalidade, pois não enfrenta todos os pedidos formulados que deveriam ser analisados naquele momento, sendo proferida decisão incompleta. Já a primeira, ao contrário, não apresenta necessariamente nenhum vício intrínseco: não há qualquer incompletude, visto que examina pedidos específicos, que se encontram maduros para imediato julgamento, sendo que o restante do objeto litigioso do processo, em razão de em relação a ele ser imprescindível maior dilação probatória, será analisado ulteriormente, completando-se, assim, a prestação jurisdicional.

xxxiii. O princípio da congruência deve ser considerado à luz do segmento de mérito analisado pela sentença parcial. Dessa forma, deve ser examinado em dois momentos diferentes, na hipótese de prolação de sentença parcial de mérito: primeiro, em relação à decisão parcial e à parcela da demanda efetivamente decidida; segundo, no tocante à decisão final e à parcela da demanda que ainda deveria ser apreciada.

xxxiv. Ainda que se considere a sentença parcial como maculada pelo vício citra petita, cogitar de sua anulação seria um grande desserviço à efetividade processual, caso a análise da parcela autônoma da demanda efetivamente julgada não seja, em si mesma, portadora de qualquer vício. Assim, a consequência decorrente seria seu aproveitamento, determinando-se o prosseguimento do processo para a decisão da parcela restante do objeto do processo, situação que naturalmente ocorreria sese considerasse inexistente o famigerado defeito.

xxxv. A razoável duração do processo encontra-se no equilíbrio entre segurança e celeridade.

xxxvi. Não há dúvidas de que o direito ao processo sem dilações indevidas integra a ideia de devido processo constitucional, sendo direito fundamental dotado de aplicabilidade imediata, por força do art. $5^{\circ}, \S 1^{\circ}$, da Constituição.

xxxvii. Além do art. 5, LXXVIII, da CF, há diversas disposições constitucionais (artigos 5', XXV; 93, II, “c”, XII e XV; e 37, caput) e infraconstitucionais (artigos 330, do CPC; 35, III e IV, do Estatuto da Magistratura; 20, do Código de Ética da Magistratura) destinadas a conferir celeridade ao processo.

xxxviii. O julgamento fracionado do mérito é ferramenta que assegura um processo efetivo e célere, pois a prática de qualquer ato processual posterior ao 
amadurecimento da demanda para julgamento, representa ofensa ao direito fundamental a um processo sem dilações indevidas.

xxxix. As sentenças parciais se mostram não apenas como possíveis, mas sim como verdadeira necessidade, à luz do direito constitucional à razoável duração do processo, o qual traz como consequência a impossibilidade de o juiz adiar a concessão da tutela jurisdicional depois de já ter formado sua convicção. Impossibilitar a fragmentação do julgamento da demanda, na hipótese de parcela do objeto processual encontrar-se pronta para imediata decisão, implica inequívoca dilação temporal indevida, afrontando ao art. 5º LXXVIII, da Constituição Federal.

xl. A desacumulação de demandas pode ocorrer por iniciativa do autor, do réu, de ambas as partes, ou do juiz.

xli. Para que se admita o julgamento fracionado do mérito, é indispensável que o objeto do processo seja complexo, em razão de cumulação de pedidos, ou que o pedido único formulado seja decomponível.

xlii. Se o objeto processual simples é decomponível, de modo que sua cisão ideal possa ocorrer em capítulos diversos e autônomos, nada impede seja julgado por meio de decisões separadas, na hipótese de amadurecimento antecipado de parcela ideal do pedido.

xliii. Ocorre cúmulo subjetivo na hipótese de uma só demanda ser deduzida por e/ou contra mais de um sujeito processual. Normalmente, o cúmulo subjetivo vem acompanhado de uma acumulação objetiva, não obstante seja prescindível a manifestação concomitante dos fenômenos.

xliv. Sendo possível a adoção de solução diversa para cada sujeito processual, nada impede que o magistrado cinda o julgamento do mérito, caso o pedido formulado se mostre maduro para julgamento em relação a parcela dos sujeitos processuais. Nessa linha, verificada a possibilidade de redução ou até mesmo de extinção do cúmulo subjetivo, deve o magistrado proferir sentença parcial de mérito, entregando de forma imediata a tutela jurisdicional pleiteada, prosseguindo o processo em relação aos demais litisconsortes.

xlv. Todavia, o litisconsórcio unitário impõe ao magistrado que adote idêntica solução para todos os litisconsortes, de modo que não haverá a divisão da decisão em capítulos diversos, sendo irrelevante ser facultativo ou necessário o litisconsórcio. 
xlvi. Assim, embora exista pluralidade de sujeitos em um dos polos da relação jurídica processual, no litisconsórcio unitário haverá demanda única, visto que a relação jurídica de direito material é uma só. Inexiste, portanto, objeto processual complexo, sendo que a sentença proferida conterá apenas um capítulo de mérito.

xlvii. É de se observar que se o objeto processual for decomponível, haverá possibilidade de prolação de sentença parcial de mérito, ainda que de litisconsórcio unitário se trate.

xlviii. A cumulação objetiva de demandas pode ocorrer por cúmulo de pedidos ou de fundamentos . Entretanto, o cúmulo objetivo por multiplicidade de fundamentos não dá ensejo à complexidade do objeto do processo, visto que, embora vários as razões de fato e de direito invocadas, o resultado útil do processo na vida dos litigantes é sempre um só.

xlix. Quanto à cumulação de pedidos, a depender de sua natureza, o autor poderá pretender a procedência de todas as demandas cumuladas (cumulação própria: simples ou sucessiva) ou de apenas algumas (cumulação imprópria: eventual ou alternativa).

1. Na cumulação simples, o julgamento fracionado do mérito pode incidir sobre qualquer dos pedidos cumulados, já que entre eles inexiste preferência ou relação de prejudicialidade.

li. Na cumulação sucessiva, o julgamento fracionado do mérito pode ter como objeto apenas o primeiro pedido, já que autônomo e prejudicial em relação ao segundo; antecipar-se o julgamento do pedido prejudicado não é possível, visto que a controvérsia existente em relação ao primário torna logicamente insustentável o exame do pedido sucessivo.

lii. Na cumulação eventual ou subsidiária, comprovada improcedência do pedido antecedente e da necessidade de dilação probatória do pedido subsequente, nada impede que o magistrado pronuncie a improcedência daquele por meio de sentença parcial de mérito, prosseguindo o processo em seus ulteriores termos para o julgamento do pedido subsequente. Tal modalidade de cumulação não comporta sentença parcial de mérito de procedência do pedido antecedente, visto que o juiz, ao assim decidir, estaria proferindo sentença final, já que eventuais pedidos subsequentes restariam prejudicados, nada mais havendo a ser apreciado no processo. 
liii. No pedido alternativo, não há qualquer espécie de cumulação de demandas, pois, não obstante sejam formulados dois pedidos, ambos se referem a uma só pretensão, já que o acolhimento de qualquer deles é suficiente à integral satisfação dos interesses do autor. Impossível que se profira sentença parcial de procedência de qualquer dos pedidos alternativos, visto que se trataria, na verdade, de decisão final. Entretanto, é possível imaginar a prolação de decisão parcial de improcedência de um dos pedidos alternativos, eliminando-se um dos bens da vida (pedido mediato) visados pelo autor, prosseguindo o processo para o exame de seu direito à obtenção do bem da vida restante.

liv. O cúmulo objetivo por multiplicidade de fundamentos não gera complexidade do objeto processual.

lv. Os fundamentos da demanda ou da defesa não integram o objeto litigioso do processo, dizendo respeito não ao mérito, mas, sim, às questões de mérito.

lvi. A autorização de prolação de sentenças parciais, trazida pela Lei n. 11.232/05, não alcança o proferimento de decisões interlocutórias que examinem apenas questões de mérito, sem implicar qualquer das hipóteses previstas no art. 269, do CPC. A sede adequada para a resolução de questões de mérito não são as decisões interlocutórias, mas sim a parte da fundamentação da sentença, nos termos dos artigos 458 e 469, do Código, sendo inviável, portanto, a cisão de seu julgamento.

lvii. A decisão interlocutória que soluciona incidentalmente questão de mérito é juridicamente inexistente, incapaz de gerar quaisquer efeitos e de transitar em julgado, não podendo sequer ser alcançada pela preclusão.

lviii. Assim, o magistrado pode e deve reexaminar a questão ao proferir sentença final, seja para retificar ou confirmar o quanto decidido em momento processual inoportuno. Se não o fizer haverá decidido, na sentença, questão prejudicada sem se manifestar sobre questão prejudicial, proferindo provimento jurisdicional em afronta aos artigos $2^{\circ}, 5^{\circ}, 325,458$, II e 459, do Código de Processo Civil.

lix. A decisão interlocutória que cinde o julgamento de questões de mérito é inexistente, enquanto a sentença subsequente, proferida sem o reexame do ponto analisado na referida interlocutória, é nula, pois não resolve integralmente a causa trazida a juízo (sentença citra petita).

lx. Duas opções se abrem à parte prejudicada em relação à sentença que analisa a demanda sem reenfrentar a questão de mérito indevidamente antecipada: 
provocar o controle jurisdicional pela via recursal, sanando-o no âmbito da mesma relação jurídica processual; (ii) ajuizar ação rescisória, no biênio decadencial, contra a sentença, sob o fundamento de essa ser citra petita, já que não analisado um dos fundamentos da demanda (ou da defesa) que mantém nítida relação de prejudicialidade com a questão principal, condicionando, assim, o resultado do julgamento do mérito.

lxi. O art. 273, § $6^{\circ}$, do Código de Processo Civil, é antecipação dos efeitos da tutela, concedido por meio de decisão interlocutória, fundada em cognição sumária, revogável e provisória. Considerá-lo como julgamento parcial antecipado implicaria reconhecer sua revogação tácita pela Lei n. 11.232/2005, tendo em vista que esse diploma normativo regulou de forma integral julgamento fracionado por meio de sentença parcial.

1xii. São três os requisitos necessários à incidência do art. $273, \S 6^{\circ}$ : (i) incontrovérsia do pedido; (ii) verossimilhança das alegações; (iii) não subordinação do pedido incontroverso a questão prejudicial .

1xiii. A antecipação dos efeitos da tutela com base na incontrovérsia parcial somente se aplica em situações de ausência de impugnação, as quais propiciam ao magistrado condições apenas de exercer cognição superficial sobre os elementos de informação dos autos. As hipóteses de reconhecimento jurídico parcial do pedido, transação parcial, renúncia parcial do direito e amadurecimento parcial de parcela do objeto litigioso do processo possibilitam cognição exauriente, ensejando a prolação e sentença parcial de mérito, nos termos dos artigos 162, § $1^{\circ}, 269$ e 330, I, todos do Código de Processo Civil.

lxiv. $\quad \mathrm{O}$ art. $273, \S 6^{\circ}$, do Código de Processo Civil, pode ser aplicado nas hipóteses em que não se verificam os efeitos da revelia (v.g., demanda versando direitos indisponíveis).

lxv. A cisão do julgamento de mérito é contemplada, em maior ou menor grau de intensidade, de forma expressa, nos ordenamentos italiano, chileno, francês, alemão e português.

lxvi. Admitida a existência do julgamento fracionado do mérito mediante sentença parcial, a questão do recurso cabível contra tal pronunciamento judicial é tormentosa na doutrina pátria, a qual se divide entre os que defendem ser cabível o recurso de agravo de instrumento e aqueles que entendem interponível a apelação. 
lxvii. A simplista negativa de existência de uma sentença parcial de mérito, classificando-a como interlocutória com objetivo único de afastar o cabimento do recurso de apelação, não enfrenta a situação de forma adequada, visto que deixa sem resposta problemas que não podem ser ignorados.

lxviii. De sentença, parcial ou final, cabe apelação, devendo os operadores do direito buscar as compatibilizações necessárias à extração da maior dose de efetividade possível do instrumento estatal.

lxix. A interposição de apelação por instrumento encontraria óbice no princípio da legalidade e da taxatividade dos recursos.

lxx. A formação de autos suplementares consubstanciar-se-ia na hipótese menos traumática ao sistema, visto que permaneceriam em primeiro grau de jurisdição, propiciando o julgamento da parcela do mérito ainda não analisada, e viabilizando o imediato exame do apelo contra a sentença parcial pelo tribunal.

1xxi. Trata-se, portanto, de mecanismo compatível com o atual sistema recursal, capaz de garantir todas as vantagens da impugnação da sentença parcial por apelação por instrumento (v.g., efeito suspensivo, prazo, preparo, possibilidade de reiteração de agravos retidos, revisão, sustentação oral, interposição de embargos infringente), sem a desvantagem da discussão acerca da necessidade de intervenção legislativa.

lxxii. As técnicas do julgamento fracionado do mérito e da sentença parcial são repelidas pela doutrina unicamente por conta das dificuldades procedimentais que acarretam no plano recursal. No entanto, é evidente que dificuldades práticas não podem servir de óbice a inviabilizar ferramentas processuais capazes de conferir significativa efetividade ao método estatal de resolução de conflitos, devendo os processualistas realizar, à luz do ordenamento vigente, as adaptações procedimentais necessárias.

1xxiii. Diante das dificuldades práticas que a prolação de sentenças parciais enseja, mostra-se necessária a aplicação ampla do princípio da fungibilidade recursal, até que nova legislação seja introduzida no sistema processual ou se firme na jurisprudência um posicionamento.

lxxiv. Entre agravo de instrumento, apelação por instrumento e formação de autos suplementares, o que não pode se admitir é prejudicar o jurisdicionado, que nada tem a ver com a imprecisão do legislador e com os diversos entendimentos adotados pelos comentadores da lei. 
lxxv. Com a possibilidade de generalização das sentenças parciais de mérito no procedimento, ganha relevante destaque o fenômeno da formação progressiva da coisa julgada, a qual é admitida pela doutrina na hipótese de divisão da sentença em capítulos autônomos.

1xxvi. A análise do mérito em mais de uma decisão no mesmo processo, possibilita a aquisição da qualidade de coisa julgada material, de forma independente, por cada uma das sentenças parciais.

lxxvii. O fenômeno da coisa julgada parcial verifica-se, a rigor, sempre que uma decisão contendo mais de um capítulo de mérito é objeto de recurso parcial, de modo que o capítulo não impugnado transitaria imediatamente em julgado. Tal raciocínio pode ser perfeitamente transportado para as situações de julgamento fracionado do mérito, diante da semelhança existente entre os fenômenos.

lxxviii. O termo inicial do prazo para propositura da ação rescisória se dará com o trânsito em julgado da sentença parcial de mérito, podendo a referida demanda desconstitutiva ser ajuizada antes mesmo de encerrado o processo no qual a decisão rescindenda foi proferida.

lxxix. Contudo, o STJ adotou entendimento contrário ao ora defendido, consubstanciado na Súmula n. 401: “O prazo decadencial da ação rescisória só se inicia quando não for cabível qualquer recurso do último pronunciamento judicial".

lxxx. Ainda que se inicie no mesmo momento o prazo de ajuizamento da rescisória de decisões transitadas em julgado em ocasiões diferentes, a multiplicidade de ações não será evitada, caso tenham sido proferidas por Tribunais diversos, devendo serem observadas as regras de competência.

lxxxi. O entendimento adotado pelo Superior Tribunal de Justiça ao considerar a ação una desprezou por completo a teoria dos capítulos da sentença.

lxxxii. No mais, a formação da coisa julgada material não está vinculada à decisão integral da lide trazida a juízo, tendo em vista que sentenças infra petita também transitam materialmente em julgado.

lxxxiii. Além disso, a formação progressiva da coisa julgada é expressamente admitida pelo art. 498, do Código de Processo Civil.

lxxxiv. A solução indicada pelo Superior Tribunal de Justiça, além de não ter o condão de alcançar o objetivo proposto, traz óbices indevidos ao julgamento fracionado 
do mérito. Mais correto o entendimento adotado pelo Tribunal Superior do Trabalho, consubstanciado na Súmula n. 100 de sua jurisprudência dominante.

lxxxv. Não há dúvidas acerca da formação progressiva da coisa julgada na hipótese de cisão do julgamento do mérito. O trânsito em julgado material independe da extinção do processo e da solução integral da lide trazida a juízo, sendo certo que este último fenômeno não tem o condão de transformar em coisa julgada as decisões anteriormente preclusas.

lxxxvi. Assim, se a decisão parcial de mérito é fundada em cognição exauriente, tendo aptidão a se tornar definitiva, é capaz de adquirir a qualidade de coisa julgada material.

lxxxvii. Por força do direito à razoável duração do processo e do direito à segurança jurídica, discrepâncias lógicas eventualmente existentes entre coisas julgadas de sentenças parciais proferidas no mesmo processo são relevantes apenas no campo das preocupações teóricas, pois cada uma das decisões parciais de mérito, por serem autônomas, é capaz de produzir seus efeitos práticos, independentemente de qualquer outra circunstância.

lxxxviii. A execução da sentença parcial de mérito não será provisória, mas, sim, definitiva, ainda mais se considerando que o julgamento da parcela da demanda restante não terá qualquer influência sobre o já decidido e materialmente transitado em julgado.

lxxxix. A execução definitiva da sentença parcial de mérito deverá ser realizada por meio da aplicação analógica do art. 475-I, § 2º do Código de Processo Civil.

xc. Rejeitar a formação da coisa julgada material parcial atenta contra os princípios da efetividade processual e da segurança jurídica. Obstar sua execução definitiva agride os princípios da celeridade e da economia processual, visto que não há sentido em estender o processo no tempo, se a tutela jurisdicional já pode ser imediatamente realizada. 


\section{BIBLIOGRAFIA}

ARAÚJO, José Henrique Mouta. "Coisa julgada progressiva \& resolução parcial do mérito", Juruá, Curitiba, 2008.

. "Tutela antecipada do pedido incontroverso: estamos preparados para a nova sistemática processual?", in Revista de Processo, n. 116, pp. 206-230.

ARMELIN, Donaldo. "Notas sobre sentença parcial e arbitragem", in Revista de Mediação e Arbitragem, n. 18, julho a setembro de 2008, pp. 274-300.

ASSIS, Araken de. "Manual da execução civil", 10ª ed., RT, São Paulo, 2006.

AYOUB, Luiz Roberto; PELLEGRINO, Antônio Pedro. "A sentença parcial", in Revista de Arbitragem e Mediação, n. 22, RT, São Paulo, jul.-set./2009, pp. 33-53.

BAPTISTA, José João. "Processo civil I: Parte geral e processo declarativo", $8^{\mathrm{a}}$ ed., Coimbra: Coimbra Editora, 2006.

BARBOSA, Rui. "Oração aos moços", 6a ed., Edições Casa de Rui Barbosa, Rio de Janeiro, 2003.

BARBOSA MOREIRA, José Carlos. "A efetividade do processo de conhecimento”, in Revista de Processo, n. 74, RT, São Paulo, abril-junho de 1994, pp. 126-135.

"A nova definição de sentença", in Temas de Direito Processual: Nona Série, Saraiva, São Paulo, 2007, pp. 167-178.

. "Comentários ao Código de Processo Civil", v. V, 10"

ed., Forense, Rio de Janeiro, 2002. 
. "Correlação entre o pedido e a sentença", in Revista

de Processo, n. 83, pp. 207-215.

. "Efetividade do processo e técnica processual", in

Temas de Direito Processual: Sexta Série, Saraiva, São Paulo, 1997.

"Item do pedido sobre o qual não houve decisão.

Possibilidade de reiteração noutro processo", in Temas de direito processual civil, $2^{\mathrm{a}}$ série, Saraiva, 1988.

“Juízo de admissibilidade no sistema dos recursos

civis", Borsói, Rio de Janeiro, 1968.

. "Miradas sobre o processo civil contemporâneo", in

Temas de Direito Processual: Sexta Série, São Paulo, Editora Saraiva, 1997.

. "O futuro da justiça: alguns mitos", in Temas de

Direito Processual: Oitava Série, São Paulo, Saraiva, São Paulo, 2004.

. "Os novos rumos do processo civil brasileiro", in

Temas de Direito Processual: Sexta Série, Saraiva, São Paulo, 1997.

"Sentença objetivamente complexa, trânsito em julgado

e rescindibilidade", in Revista de Processo, n. 141, RT, São Paulo, nov./2006, pp. 7-19.

. "Tutela de urgência e efetividade do direito", in Temas

de direito processual:Oitava Série, Saraiva, São Paulo, 2004.

BEDAQUE, José Roberto dos Santos. “Algumas considerações sobre o cumprimento da sentença condenatória", in Revista do Advogado, n. 85, AASP, São Paulo, maio de 2006, pp. 63-77.

. "Efetividade do processo e técnica processual",

Malheiros, São Paulo, 2006. 
“Os elementos objetivos da demanda examinados à luz do contraditório", in CRUZ E TUCCI, José Rogério (coord.); BEDAQUE José Roberto dos Santos (coord.). "Causa de pedir e pedido no processo civil (questões polêmicas)", RT, São Paulo, 2002, pp. 13-52.

" "Tutela cautelar e tutela antecipada: tutelas sumárias e de urgência (tentativa de sistematização)", 5ª ed., Malheiros, São Paulo, 2009.

BONDIOLI, Luis Guilherme Aidar. "O novo CPC: a terceira etapa da reforma", Saraiva, São Paulo, 2006.

BONÍCIO, Marcelo José Magalhães. "Capítulos de sentença e efeitos dos recursos", RCS Editora, São Paulo, 2006.

. "Notas sobre a tutela antecipada 'parcial' na nova reforma do Código de Processo Civil", in Revista dos Tribunais, n. 808, fevereiro de 2003, pp. 73-81.

BRASIL. Senado Federal. "Anteprojeto do novo Código de Processo Civil”, disponível em http://www.senado.gov.br/senado/novocpc/pdf/Anteprojeto.pdf, acessado em 16.5.11.

BRASIL. Congresso Nacional. "Exposição de motivos do Código de Processo Civil, Lei n. 5.869, de 11 de janeiro de 1973”, disponível em http://www.ombadvocacia.com.br/acervo/CODIGOS/CODIGOPROCESSOCIVIL.PDF , acessado em 6.7.11.

BUENO, Cássio Scarpinella. "A nova etapa da reforma do Código de Processo Civil: comentários sistemáticos às Leis n. 11.187, de 19-10-2005, e 11.232, de 22-12-2005", v. 1, Saraiva, São Paulo, 2006. 
CALMON DE PASSOS, José Joaquim. “O problema do acesso à justiça no Brasil”, in Revista de Processo, ano X, n. 39, São Paulo, Editora Revista dos Tribunais, julhosetembro de 1985, pp. 78-97.

CAMARDI, Giuseppe. "Le sentenze non definitive su questioni preliminari di mérito", tesi di dottorato apresentada à Universitá di Bologna, disponível em 〈http://amsdottorato.cib.unibo.it/771/1/Tesi_Camardi_Giuseppe.pdf>, acessado em 16.7.2012.

CAMBI, Accácio. "Novo conceito de sentença e sua repercussão no ordenamento processual (na classificação das sentenças e no sistema recursal), in Revista de Processo, n. 182, RT, São Paulo, abril de 2010, pp. 17-55.

CAPPELLETTI, Mauro; GARTH Bryant; NORTHFLEET, Ellen Gracie (trad.). “Acesso à justiça”, Fabris, Porto Alegre, 2002.

CARMONA, Carlos Alberto. "Ensaio sobre a sentença arbitral parcial", in Revista de Processo, n. 165, RT, São Paulo, nov. 2008, pp. 9-28.

"Reforma da Constituição e processo: promessas $e$ perspectivas", in Revista da Procuradoria Geral do Estado de São Paulo, 61/62, janeirodezembro de 2005, pp. 1-12.

CARNEIRO, Athos Gusmão. "Ação rescisória, biênio decadencial e recurso parcial", disponível em http://www.abdpc.org.br/abdpc/artigos/Athos\%20Gusm\%C3\%A3o\%20Carneiro\%20for matado.pdf, acessado em 19.1.12.

“Da antecipação de tutela", Forense, Rio de Janeiro, 2002. . "Do 'cumprimento da sentença', conforme a Lei $n$. 11.232/2005. Parcial retorno ao medievalismo? Por que não?”, in Revista do Advogado, n. 85, AASP, São Paulo, maio de 2006, pp. 13-35. 
CARPI, Federico; COLESANTI, Vittorio; TARUFFO, Michele. "Commentario breve al codice di procedura civile", 4ª ed., Padova: CEDAM, 2002.

CARRIÓ, Genaro. "Notas sobre derecho y lenguaje". $4^{\mathrm{a}}$ edição, Abeledo-Perrot, Buenos Aires, 1990.

CASSOL, Maria Helena. "Perspectivas atuais da tutela antecipada e a quebra do princípio da unicidade da sentença", in Revista da AJURIS, n. 111, AJURIS, Rio Grande do Sul, setembro de 2008, pp. 151-176.

CAZETTA JÚNIOR, José Jesus. “Cumulação simples de pedidos e julgamento incompleto do recurso especial: variações em tono de uma questão polêmica", in CRUZ E TUCCI, José Rogério (coord.); BEDAQUE José Roberto dos Santos (coord.). Causa de pedir e pedido no processo civil (questões polêmicas), RT, São Paulo, 2002, pp. 429-448.

CENCI, Fábio; SOUZA, MARCHI, Paola M. Casagrande. "Novo (novo?) conceito de sentença", in Revista Bonijuris, n. 557, Instituto de Pesquisas Jurídicas Bonijuris, Curitiba, abril de 2010, pp. XXI-XXVIII.

CHIOVENDA, Giuseppe. "Instituições de direito processual civil", Bookseller, Campinas, 2009.

CINTRA, Antonio Carlos de Araújo; DINAMARCO, Cândido Rangel; GRINOVER, Ada Pellegrini. "Teoria geral do processo", 20ª ed., Malheiros Editores, São Paulo, 2004.

CORTEZ, Cláudia Helena Poggio. "O novo conceito de sentença visto pelos tribunais" in Revista de Processo, n. 171, RT, São Paulo, maio de 2009, pp. 282-297.

CRUZ E TUCCI, José Rogério. "Duração razoável do processo (art. 5", LXXVIII da Constituição Federal)", in MARTINS, Ives Gandra da Silva (coord.); JOBIM, Eduardo (coord). O Processo na Constituição, QuartierLatin, São Paulo, 2008, pp. 321-342. 
. "Reflexões sobre a cumulação subsidiária de pedidos",

in CRUZ E TUCCI, José Rogério (coord.); BEDAQUE José Roberto dos Santos (coord.). Causa de pedir e pedido no processo civil (questões polêmicas), RT, São Paulo, 2002, pp. 279-294.

. “Tempo e processo", RT, São Paulo, 1997.

CRUZ E TUCCI, José Rogério; AZEVEDO, Luis Carlos de. "Lições de história do processo civil romano", $1^{\text {a }}$ ed., RT, São Paulo, 2001.

DALL'ALBA, Felipe Camilo. “Julgamento antecipado ou antecipação dos efeitos da tutela do pedido incontroverso?", in Revista de Processo, n. 128, pp. 207-223.

DIAS, Jean Carlos. "A configuração da coisa julgada parcial e suas repercussões processuais no âmbito do cumprimento das sentenças", in Revista de Processo n. 135, RT, São Paulo, maio de 2006, pp. 267-276.

DIDIER JUNIOR, Fredie. “Ações concorrentes. Prejudicialidade e preliminaridade. Conexão. Suspensão do processo. Litispendência. Continência. Cumulação subsidiária de pedidos. Cumulação ulterior de pedidos. Honorários advocatícios", in Revista Forense, n. 385, Forense, Rio de Janeiro, maio-jun/2006, pp. 235-251.

. “Inovações na antecipação dos efeitos da tutela e a resolução parcial do mérito", in Revista de Processo n. 110, RT, São Paulo, abril-junho de 2003, pp. 225-251.

DINAMARCO, Cândido Rangel. “A reforma da reforma”, Malheiros, São Paulo, 2002.

.Capítulos de sentença”, 4 ed., Malheiros, São Paulo, 2009.

.Fundamentos do processo civil moderno", $3^{\mathrm{a}}$ ed., Malheiros, São Paulo, 2000. 
"Instituições de direito processual civil", $6^{\mathrm{a}}$ ed., Malheiros Editores, São Paulo, 2009.

"Nova era do processo civil", $1^{\mathrm{a}}$ ed., Malheiros, São

Paulo, 2004.

DORIA, Rogéria Dotti. “A tutela antecipada em relação à parte incontroversa da demanda”, RT, São Paulo, 2004.

FERRAZ JUNIOR, Tércio Sampaio. "Introdução ao estudo do direito: técnica, decisão, dominação", 2ª ed. Atlas, São Paulo, 1994.

FERREIRA, William Santos. "Aspectos polêmicos e práticos da nova reforma processual civil", Forense, Rio de Janeiro, 2003.

FICHTNER, José Antonio; MONTEIRO, André Luís. "Sentença parcial de mérito na arbitragem", in Temas de arbitragem: primeira série, Renovar, São Paulo, 2010, pp. 149-188.

FLACH, Rafael. "A súmula 401 do Superior Tribunal de Justiça e a coisa julgada progressiva", in Revista de Processo, n. 185, RT, São Paulo, julho de 2010, pp. 175210.

FONSECA, Rodrigo Garcia da. "A arbitragem e a reforma processual da execução", in Revista de Arbitragem e Mediação, n. 14, RT, São Paulo, jul-set./2007, pp. 30-47.

FRIAS, Jorge Eustácio da Silva. "A multa pelo descumprimento da condenação em quantia certa e o novo conceito de sentença", in Revista dos Tribunais, v. 858, abril de 2007, pp. 48-81.

GAJARDONI, Francisco da Fonseca. "O princípio constitucional da tutela jurisdicional sem dilações indevidas e o julgamento antecipadíssimo da lide”, in Revista IOB de Direito Civil e Processual Civil, n. 45, jan-fev./2007, pp. 102-131. 
GARCIA, Gustavo Filipe Barbosa. "Capítulos autônomos da decisão e momentos de seu trânsito em julgado", in Revista de Processo n. 111, RT, São Paulo, 2003, pp. 290305.

.Terceira fase da reforma do Código de Processo

Civil”, v. 2, Método, São Paulo, 2006.

GIUSTI, Gilberto; MARQUES, Ricardo Dalmaso. "Sentenças arbitrais parciais: uma análise prática”, in Revista de Arbitragem, n. 26, RT, São Paulo, jul.-set./2010, pp. 4658.

GONÇALVES FILHO, João Gilberto. "O princípio constitucional da eficiência no processo civil". 2010. Tese (Doutorado em Direito Processual) - Faculdade de Direito, Universidade de São Paulo, São Paulo, 2010. Disponível em: http://www.teses.usp.br/teses/disponiveis/2/2137/tde-17112011-085839/, $\quad$ acessado em3.7.2012.

GRECO, Leonardo. "Concurso e cumulação de ações", in Revista de Processo, n. 147, RT, São Paulo, maio de 2007, pp. 11-26.

"Primeiros comentários sobre a reforma da execução oriunda da Lei n. 11.232/05”, in Revista do Advogado, n. 85, AASP, São Paulo, maio de 2006, pp. 97-111.

GUERREIRO, Mario Augusto Figueiredo de Lacerda. "Critérios para a densificação do conceito de 'prazo razoável' no processo civil', in Revista de Direito do Tribunal de Justiça do Estado do Rio de Janeiro, n. 70, jan-mar/2007, pp. 47-67.

HOFFMAN, Paulo. "O direito à razoável duração do processo e a experiência italiana", in WAMBIER, Teresa Arruda Alvim (coord.), WAMBIER, Luiz Rodrigues (coord.), GOMES JR., Luiz Manoel (coord.), FISCHER, Octavio Campos (coord.), FERREIRA, William Santos (coord.), Reforma do Judiciário, RT, São Paulo, 2005, pp. 571-589. 
JORGE, Flávio Cheim. "Teoria geral dos recursos cíveis", Forense, Rio de Janeiro, 2003.

JORGE, Flávio Cheim; RODRIGUES, Marcelo Abelha; DIDIER JUNIOR, Fredie. " $A$ terceira etapa da reforma processual civil: comentários às Leis $n .11 .187$ e 11.232, de 2005; 11.276, 11.277 e 11.280, de 2006”, Saraiva, São Paulo, 2006.

"A nova reforma processual", $2^{\mathrm{a}}$ ed. Saraiva, 2003, São

Paulo.

LAZARI, Rafael José Nadim; SOUZA, Gelson Amaro de. "Breves apontamentos sobre a apelação por instrumento", $\quad$ disponível em http://www.abdpc.org.br/abdpc/artigos/Breves\%20Apontamentos\%20sobre\%20a\%20A pela\%C3\% A7\%C3\%A3o\%20por\%20Instrumento\%20\%20Rafael\%20Jos\%C3\%A9\%20Nadim\%20de\%20LAZARI\%20e\%20Gelson\%20Ama ro\%20de\%20SOUZA.pdf, acessado em 28.6.11.

LENZA, Pedro. "Direito Constitucional Esquematizado", 12a ed., Saraiva, São Paulo, 2008.

LEONEL, Ricardo de Barros. "Objeto litigioso do processo e o princípio do duplo grau de jurisdição", in CRUZ E TUCCI, José Rogério (coord.); BEDAQUE José Roberto dos Santos (coord.). Causa de pedir e pedido no processo civil (questões polêmicas), RT, São Paulo, 2002, pp. 343-410.

LIEBMAN, Enrico Tullio. "Eficácia e autoridade da sentença", $3^{\mathrm{a}}$ ed., Forense, Rio de Janeiro, 1984.

LOPES, João Batista. “Tutela antecipada no processo civil brasileiro”, RT, São Paulo, $3^{\mathrm{a}}$ ed., 2007.

LUCCA, Rodrigo Ramina de. "Antecipação de tutela da parcela incontroversa do mérito $e \quad o$ conceito de sentença", disponível em 
http://www.abdpc.org.br/abdpc/artigos/Rodrigo\%20Ramina\%20de\%20Lucca.pdf, acessado em 28.6.11.

LUCON, Paulo Henrique dos Santos. "Estabilização da tutela antecipada e julgamento parcial do mérito", disponível em http://direitoprocessual.org.br/fileManager/Paulo_Lucon__Estabilizao_da_tutela_antec ipada_e_julgamento_parcial_do_mrito.doc, acessado em 10.1.12.

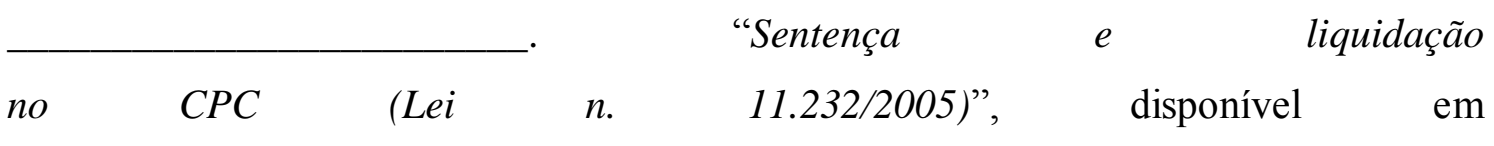
http://novo.direitoprocessual.org.br/fileManager/Paulo_Lucon_Sentena_e_liquidao_n o_CPC.doc, acessado em 6.6.11.

LUISO, Francesco Paolo. "Diritto processuale civile", 2ª ed., Giuffrè, Milano, 1999.

MACHADO, Daniel Carneiro. "O novo conceito de sentença e a natureza jurídica do ato judicial que resolve questões incidentais.", in Revista do Tribunal Regional da $1^{\mathrm{a}}$ Região, v. 22, n. 4, abril de 2010, disponível em http://bdjur.stj.jus.br/xmlui/bitstream/handle/2011/34805/novo_conceito_senten\%C3\% A7a_machado.pdf?sequence $=1$, acessado em 9.7.11.

MALUF, Carlos Alberto Dabus. "Cumulação de ações no processo civil”, in Revista de Processo n. 17, RT, São Paulo, jan.-mar./1980, pp. 61-78.

MANDRIOLI, Crisanto. “Diritto processuale civile”, v. II, 14a ed., Torino, 2002.

MARCATO, Antonio Carlos. “Ação de consignação em pagamento”, 6 a ed., Malheiros, São Paulo, 2001.

MARINONI, Luiz Guilherme. "Técnica processual e tutela dos direitos", RT, São Paulo, 2004. . "Tutela antecipatória e julgamento antecipado. Parte

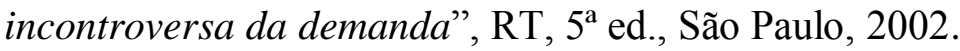


"Tutela antecipatória de parcela do pedido ou de pedido cumulado", in Revista do TST, n. 66, jan.-mar./2000, pp. 77-80.

MARINONI, Luiz Guilherme; ARENHART, Sérgio Cruz. "Manual do processo de conhecimento", $5^{\mathrm{a}}$ ed., RT, São Paulo, 2006.

MARTINS, Pedro Batista. "A arbitragem e o mito da sentença parcial", in CARMONA, Carlos Alberto (coord.); LEMES, Selma Ferreira (coord.); MARTINS, Pedro Batista (coord.). Arbitragem: Estudos em Homenagem ao Prof. Guido Fernando da Silva Soares in memoriam, Atlas, São Paulo, 2007, pp. 267-284.

MARTINS, Renato Castro Teixeira. "Apelação por instrumento", in MEDINA, José Miguel Garcia (coord.); CRUZ, Luana Pedrosa de Figueiredo (coord.); CERQUEIRA, Luiz Otávio Siqueira de (coord.); GOMES JR., Luis Manoel (coord.). Os poderes do juiz e o controle das decisões judiciais: estudos em homenagem à professora Teresa Arruda Alvim Wambier, RT, São Paulo, 2008, pp. 836-845.

MARTINS, Sandro Gilbert. "Reflexos do novo conceito de sentença (CPC, art. 162, § $1^{\circ}$, com a redação dada pela Lei n. 11.232/2005)", in Revista de Processo, n. 163, RT, São Paulo, setembro de 2008, pp. 305-311.

MELLO, Rafael Corte. "Sentenças liminares ou sentenças parciais de mérito?”, in ARMELIN, Donaldo (coord.). Tutelas de urgência e cautelares, Saraiva, São Paulo, 2010, pp. 968-985.

MILMAN, Fabio. "O novo conceito legal de sentença e suas repercussões recursais: primeiras experiências com a apelação por instrumento", in Revista de Processo, n. 150, RT, São Paulo, agosto de 2007, pp. 160-174.

MITIDIERO, Daniel. "'Direito fundamental ao julgamento definitivo da parcela incontroversa: uma proposta de compreensão do art. 273, $\S 6^{\circ}, C P C$, na perspectiva do direito fundamental a um processo sem dilações indevidas (art. 5, LXXVIII, CF/88)", in Revista de Processo, n. 149, pp. 105-119. 
MONTEIRO FILHO, Ralpho Wando de Barros; LUZ, Rolando Maria da. “O novo conceito de sentença", in Atualidade do Processo Civil, vol. I, ABDR, São Paulo, 2007, pp. 141-151.

MONTESANO, Luigi. “Sentenza parziale su questione di merito non 'preliminare' di domanda 'indivisibile"', in Riv. dir. proc. 1970.

NALINI, José Renato. “Ética da Magistratura”, RT, São Paulo, 2009.

NEFFA JUNIOR, José Antônio. "Acesso à justiça e recorribilidade imediata das decisões interlocutórias em primeiro grau de jurisdição", disponível em http://www.fdv.br/mestrado/dissertacoes/Jose\%20Antonio\%20Neffa\%20Junior.pdf, acessado em 11.7.11.

NEGRÃO, Theotônio. "Comentários ao Código de Processo Civil e legislação processual em vigor", 40ª ed., Saraiva, São Paulo, 2008.

NEVES, Daniel Amorim Assumpção. “O novo conceito de sentença”, in Reforma do CPC: leis 11.187/2005, 11.232/2005, 11.276/2006, 11.276/2006 e 11.280/2006, RT, São Paulo, 2006.

"O novo conceito de sentença de mérito e os problemas recursais", in BRUSCHI, Gilberto Gomes (coord.); SHIMURA, Sérgio (coord.). Execução civil e cumprimento de sentença, vol. 2, Método, São Paulo, 2007, pp. 71-86.

NERY JUNIOR, Nelson. "Atualidades sobre o processo civil: a reforma do Código de Processo Civil brasileiro de 1994 e de 1995”, 2ª ed., RT, São Paulo, 1996.

NERY JUNIOR, Nelson; NERY, Rosa Maria de Andrade. "Comentários ao Código de Processo Civil e legislação extravagante”, 10ª ed., RT, São Paulo, 2008.

NORONHA, Carlos Silveira. "Sentença civil - perfil histórico e dogmático”, RT, São Paulo, 1995. 
NOTARIANO JUNIOR, Antonio; BRUSCHI, Gilberto Gomes. " $O$ julgamento antecipado da lide e a antecipação de tutela em caso de pedidos incontroversos", in ARMELIN, Donaldo (coord.). "Tutelas de urgência e cautelares: estudos em homenagem a Ovídio A. Baptista da Silva”, Saraiva, São Paulo, 2010, pp. 121-135.

OLIANI, José Alexandre Manzano. "Cumprimento da sentença interlocutória que condena ao pagamento de soma, de acordo com a Lei 11.232/05", in SANTOS, Ernane Fidélis (coord.); WAMBIER, Luiz Rodrigues (coord.); NERY JR., Nelson (coord.); WAMBIER, Teresa Arruda Alvim (coord.). Execução civil: estudos em homenagem ao professor Humberto Theodoro Júnior, RT, São Paulo, 2007, pp. 173-183.

OLIVEIRA, Bruno Silveira de. "Um novo conceito de sentença?" in Revista de Processo, n. 149, RT, São Paulo, julho de 2007, pp. 120-138.

OLIVEIRA, Guilherme Peres de. "Novo conceito de sentença: análise da jurisprudência acerca do recurso cabível nas situações duvidosas e aplicação do princípio da fungibilidade”, in Revista de Processo, n. 164, RT, São Paulo, out./2008, pp. 296-308.

PISANI, Andrea Proto. "Lezioni di diritto processuale civile", 4 ed. Napoli: Juvene, 2002.

POITTEVIN, Ana González. "Recorribilidade das decisões interlocutórias", Juruá, Curitiba, 2008.

PONTES DE MIRANDA, Francisco Cavalcanti. "Tratado da ação rescisória", 5 a ed., Forense, Rio de Janeiro, 1976.

REDONDO, Bruno Garcia. "Sentença parcial de mérito e apelação em autos suplementares", in Revista de Processo, n. 160, RT, São Paulo, junho de 2008, pp. $142-$ 156. 
RIBEIRO, Darci Guimarães. "A garantia constitucional do contraditório e as presunções contidas no $\S 6^{\circ}$ do art. 273 do CPC", in ARMELIN, Donaldo (coord.). "Tutelas de urgência e cautelares: estudos em homenagem a Ovídio Araújo Baptista da Silva”, Saraiva, São Paulo, 2010, pp. 342-359.

RIBEIRO, José Antunes. “Código de processo civil anotado”, Coimbra: Verbo Jurídico, 2006.

RODRIGUES, Horácio Wanderlei. "Acesso à justiça no direito processual brasileiro", Acadêmica, São Paulo, 1994.

SANT'ANNA, Paulo Afonso de Souza. "Hipóteses para concessão da tutela antecipatória da parte incontroversa da demanda (art. 273, $\S 6^{\circ}, C P C$ )", in Revista de Processo, n. 121, pp. 117-132.

"Sentença parcial", in MEDINA, José Miguel Garcia (coord.); CRUZ, Luana Pedrosa de Figueiredo (coord.); CERQUEIRA, Luís Otávio Sequeira de (coord.); Junior, Luiz Manoel Gomes (coord). "Os poderes do juiz e o controle das decisões judiciais”, RT, São Paulo, 2008, pp. 442-463.

SATTA, Salvatore. Diritto processuale civile, Padova: Casa Editrice Dott. Antonio Milani, 1981.

SCARPARO, Eduardo Kochenborger. "Sentenças parciais? Considerações a partir da reforma do art. 162, $\S 1^{o}$, do Código de Processo Civil", disponível em http://www.scarparo.adv.br/artigos/sent.pdf, acessado em 6.6.11.

SEGUEL, Alejandro Romero. "La acumulación inicial de acciones", Santiago: Conosur, 2000.

SICA, Heitor Vitor Mendonça. "Algumas implicações do novo conceito de sentença, de acordo com a Lei n. 11.232/2005", in CARMONA, Carlos Alberto (coord.). Reflexões sobre a reforma do Código de Processo Civil, Atlas, São Paulo, 2007, pp. 186-209. 
SILVA, Ovídio Araújo Baptista da. "A demanda", in SILVA, Ovídio Araújo Baptista da; GOMES, Fábio. "Teoria geral do processo civil”, $3^{\mathrm{a}}$ ed., RT, São Paulo, 2002, pp. 239-271.

. "Conteúdo da sentença e mérito da causa”, in Sentença

e coisa julgada: ensaios e pareceres, $4^{\mathrm{a}}$ ed., Forense, Rio de Janeiro, 2006, pp. 231-244.

- 'Cumulação de demandas e 'execução' de sentença

constitutiva", in Da sentença liminar à nulidade da sentença, Forense, Rio de Janeiro, 2001, pp.349-370.

. "Decisões interlocutórias e sentenças liminares", in Da sentença liminar à nulidade da sentença, Forense, Rio de Janeiro, 2001, pp. 3-24.

SILVA FILHO, Ricardo de Oliveira. "A sentença parcial de mérito e o processo civil moderno", in Revista da AJURIS, n. 108, AJURIS, Porto Alegre, dezembro de 2007, pp. $285-297$.

SOUZA, Gelson Amaro de; FILHO, Gelson Amaro de Souza. "Sentença - Em busca de uma nova definição" in Repertório de Jurisprudência IOB, n. 5, IOB, São Paulo, $1^{\text {a }}$ quinzena de março de 2009, pp. 185-197.

SOUZA, Rubens Hess Marins de. “A cumulação de demandas no processo civil de conhecimento", in Revista Forense, n. 382, Forense, Rio de Janeiro, nov-dez/2005, pp. 501-511.

SOUZA JUNIOR, Sidney Pereira de. "Sentenças parciais no processo civil consequências no âmbito recursal", Método, São Paulo, 2009.

TARTUCE, Flávio. “Manual de direito civil”, v. único, Método, São Paulo, 2011. 
TARUFFO, Michele; COMOGLIO, Luigi Paolo; FERRI, Conrado. "Lezioni sul processo civile", $2^{\text {a }}$ ed., Bologna: Mulino, 1995.

TEIXEIRA, Guilherme Puchalski. "Sentenças objetivamente complexas: impossibilidade do trânsito em julgado parcial", in Revista de Processo n. 162, RT, São Paulo, agosto de 2008, pp. 228-249.

TERRA, Rogério Luiz dos Santos. “A antecipação de tutela do pedido incontroverso: questões polêmicas derivadas do art. $273, \S 6^{\circ}$, do Código de Processo Civil", in Revista Forense, vol. 412, pp. 251-264.

TESHEINER, José Maria Rosa. Nova sistemática processual civil, $2^{\mathrm{a}}$ ed., Plenum, Caxias do Sul, 2006.

THEODORO JUNIOR, Humberto. "As novas reformas do Código de Processo Civil", Forense, Rio de Janeiro, 2006.

. "Coisa julgada: pluralidade e unicidade (súmula $n$. 401 do STJ)", disponível em http://www.rkladvocacia.com/arquivos/artigos/art_srt_arquivo20111212104742.pdf, acessado em 23.1.12.

Forense, Rio de Janeiro, 2003. . “O problema da recorribilidade das interlocutórias no processo civil brasileiro", disponível em http://www.abdpc.org.br/artigos/artigo47.htm, acessado em 7.7.11.

VAREJÃO, José Ricardo do Nascimento. “As classificações, a lei 11.232/2005 e o 'novo' conceito de sentença”, in WAMBIER, Teresa Arruda Alvim (coord.). Aspectos Polêmicos da Nova Execução, 3: de títulos judiciais, Lei 11.232/2005, RT, São Paulo, 2006, pp. 369-395. 
VARGAS, Jorge de Oliveira. "O novo conceito de sentença e o recurso daquela que não extingue o processo: apelação ou agravo de instrumento?", in Revista de Processo, n. 148, RT, São Paulo, junho de 2007, pp. 111-118.

VAZ, Paulo Afonso Brum. "Tutela antecipada fundada na técnica da ausência de controvérsia sobre o pedido ( $\$ 6^{\circ}$ do art. 273 do $\left.C P C\right)$ ", in Revista de Processo, n. 131, pp. 124-144.

VIGLIAR, José Marcelo Menezes. "Pedido genérico e projeto de sentença", in CRUZ E TUCCI, José Rogério (coord.); BEDAQUE José Roberto dos Santos (coord.). “Causa de pedir e pedido no processo civil (questões polêmicas)", RT, São Paulo, 2002, pp. 295-342.

WALD, Arnoldo. "A validade da sentença arbitral parcial nas arbitragens submetidas ao regime da CCI", in Revista de Direito Bancário do Mercado de Capitais e da Arbitragem, n. 17, RT, São Paulo, julho a setembro de 2002, pp. 329-341.

WAMBIER, Luiz Rodrigues. “Considerações sobre a parte incontroversa da demanda na ação movida pelo devedor: os arts. 49 e 50 da Lei 10.391/2004”, in Revista de Processo, n. 143, pp. 26-41.

WAMBIER, Luis Rodrigues; WAMBIER, Teresa Arruda Alvim; MEDINA, José Miguel Garcia. "Breves comentários à nova sistemática processual civil”, vol. 2, RT, São Paulo, 2006.

WAMBIER, Teresa Arruda Alvim. "Nulidades do processo e da sentença", $4^{\mathrm{a}}$ ed., RT, São Paulo, 1997. "O agravo e o conceito de sentença", in Revista de Processo, n. 144, RT, São Paulo, fevereiro de 2007, pp. 243-256.

. "O conteúdo das decisões judiciais como fator determinante para sua classificação e para a indicação dos recursos cabíveis", in Revista de Processo, n. 162, pp. 273-296. 


$$
\text { . “O novo regime do agravo". } 2^{\mathrm{a}} \text { ed., RT, São Paulo, }
$$

1996.

. "O óbvio que não se vê: a nova forma do princípio da fungibilidade", in Revista de Processo n. 167, RT, São Paulo, pp. 134-138.

“Os agravos no CPC brasileiro", 4 ed., RT, São Paulo,

2006.

WATANABE, Kazuo. “Acesso à justiça e sociedade moderna”, in GRINOVER, Ada Pellegrini (org.); DINAMARCO, Cândido Rangel (org.); WATANABE, Kazuo (org.). Participação e processo. RT, São Paulo, 1988, pp. 128 a 135.

“Da cognição no processo civil", 2ª ed., CEBEPEJ, São

Paulo, 1999.

ZAVASCKI, Teori Albino. "Antecipação da tutela em face de pedido incontroverso", in Revista Jurídica, n. 301, novembro de 2002, pp. 30-35. 